


\section{O ESPIRITUAL \\ E A CENA: \\ A TRANSFORMAÇÃO \\ DO ESPAÇO CÊNICO \\ DOS ESPETÁCULOS DE PETER BROOK.}

Tese de Doutorado apresentada ao Programa de

Pós-Graduação em Artes Cênicas da Escola de Comunicação e Artes da Universidade de São Paulo, como parte dos requisitos para a obtenção do título de Doutor em Artes Cênicas.

Área de concentração: Teoria e Prática do Teatro

Oientador: Prof. Dr. Fausto R. P. Viana

São Paulo 
Autorizo a reprodução e divulgação total ou parcial deste trabalho, por qualquer meio convencional ou eletrônico, para fins de estudo e pesquisa, desde que citada a fonte.

Catalogação na Publicação

Serviço de Biblioteca e Documentação

Escola de Comunicações e Artes da Universidade de São Paulo Dados inseridos pelo(a) autor(a)

Ortiz, Sergio Ricardo Lessa

O Espiritual e a Cena: A transformação do espaço cênico dos espetáculos de Peter Brook / Sergio Ricardo Lessa Ortiz ; orientador, Fausto Roberto Poço Viana. -- São Paulo, 2020. 296 p.: il.

Tese (Doutorado) - Programa de Pós-Graduação em Artes Cênicas - Escola de Comunicações e Artes / Universidade de São Paulo.

Bibliografia

Versão corrigida

1. Cenografia 2. Trajes de cena 3. Peter Brook 4. Teatro Sagrado 5. Espaço teatral I. Viana, Fausto Roberto Poço II. Título.

CDD 21.ed. - 792

Elaborado por Alessandra Vieira Canholi Maldonado - CRB-8/6194 
Nome: ORTIZ, Sergio Ricardo Lessa

Título: $\mathbf{O}$ espiritual e a Cena: a transformação do

espaço cênico dos espetáculos de Peter Brook

Tese apresentada à Escola de Comunicação e Artes da Universidade de São Paulo para obtenção do grau de Doutor em Artes Cênicas.

Aprovado em:

Banca Examinadora

Prof. Dr.

Instituição:

Julgamento:

Prof. Dr.

Instituição:

Julgamento:

Prof. Dr.

Instituição:

Julgamento:

Prof. Dr.

Instituição:

Julgamento:

Prof. Dr.

Instituição:

Julgamento: 
Dedico esse trabalho à minha ancestralidade que tornou possível a realização dessa pesquisa, aos meus pais (Maryléa e Paulo), meus familiares (Vera, Carolina e Beatriz), ao meu esposo Vinícius - companheiro de todos os momentos, ao meu irmão (Felipe), e a todos os meus descendentes que virão perpetuar esse caminhar da vida e pesquisa. 


\section{AGRADECIMENTOS}

Quero agradecer a todos os amigos, aos familiares e profissionais que me estiveram ao meu lado nessa jornada: aos que me incentivaram e apoiaram a poder enveredar por este caminho sem volta que é a vontade de estar imerso na pesquisa científica. A concretização deste trabalho e o seu aprofundamento não seria possível sem suporte permanente de todos a minha volta.

Dessa forma, meus agradecimentos são:

Ao meu querido e eterno orientador Fausto Roberto Poço Viana que me encorajou e conduziu de maneira primorosa o desenvolvimento deste trabalho, me desafiando nos momentos necessários e amparando diante das dificuldades. Ele é sem dúvida uma pessoa iluminada.

Ao meu esposo, companheiro de muitos momentos, que acorda todos os dias ao meu lado e faz com que os dias de escrita sejam bem mais prazerosos. Ele é sem dúvida também uma pessoa de muita positividade que está a todo momento me auxiliando no meu amadurecimento e crescimento pessoal e profissional

À minha família, Luiz Felipe Lessa Ortiz, Maryléa Fátima Lessa Ortiz e Paulo Sérgio Ortiz, que estiveram sempre na torcida para que pudesse chegar à conclusão dessa jornada importante da pesquisa. 
Aos meus familiares, Ana Carolina Lessa Teixeira, Beatriz Lessa de Mello, Enzo Lessa Giuga (membro mais novo da família), Vera Lea Lessa, aos meus sogros queridos que me apoiam mesmo a distância Enilza Modolo e Valdeci de Melo Santos, ao meu cunhado Gabriel Modolo e a futura integrante, muito mais do que especial, Amanda Lino de Faria, que veio de forma magnífica integrar a nossa família.

Ao meu antigo coordenador e agora amigo de jornada, que me estimulou a me aprimorar profissionalmente Ênio Moro Júnior. Ao meu grande amigo de coordenação, que esteve ao meu lado em diversos desafios e que se tornou uma pessoa bastante especial em minha vida, Antonio Rodrigues Netto.

Aos meus amigos de profissão que me acolheram de forma bastante especial, e que me inspiram e dividem momentos especiais ao lado da difícil arte de educar, Debora Sanches, Denise Xavier, Elisabeth Cristina do Amaral Ecker, Leonardo Loyolla, Luis Octávio Rocha e Silvia Vitale e em especial aquela pessoa maravilhosa, doce e sincera que tem me auxiliado em diversos momentos desse novo desafio e que pode me ajudar a revisar este texto, Aline Nasralla Regino.

Ao meu companheiro de Coordenação, que tem se revelado um grande parceiro de trabalho Giovanni Campari, com o qual tenho aprendido bastante. Assim como, meus superiores que têm confiado em meu trabalho e se tornaram pessoas bastante especiais, compreensivas e humanas, as quais tenho grande admiração: Profa. Josiane Tonelotto, Prof. Marcelo Romero e Prof. Francisco Starke.

Aos meus amigos mais que especiais e companheiros de jornada, Alan da Rocha Brum, Ana Carolina Carmona Ribeiro, Bárbara Menezes Sousa Barreto, Carolina Bassi de Moura, Clarissa de Almeida Paulillo, Helena Marão, Luana Sato, Mônica de Medeiros Mongelli, Zenaide dos Santos Reis, que estiveram envolvidos direta e indiretamente nesse processo.

E a todos aqueles que, embora não citados, fizeram parte desta magnífica jornada. 
Há três verdades: minha verdade, sua verdade e a verdade. Minha verdade, assim como sua verdade, não passa de uma fração da verdade.

\section{Tierno Bokar}




\section{RESUMO}

O espiritual e a cena: a transformação do espaço cênico dos espetáculos de Peter Brook investiga se a busca pelo aprimoramento da espiritualidade ou, o que se denominou como busca pelo sagrado em cena, implicou na simplificação da cenografia e na transformação da apropriação espacial e valorização do espaço cênico nas obras de um dos mais importantes encenadores do século $X X$, que também influenciou bastante 0 pensamento teatral no começo do século $X X I$ - Peter Brook, responsável por uma intensa pesquisa sobre o teatro ritualístico/sagrado. $O$ trabalho evidencia as questões expostas anteriormente sobre o processo de simplificação dos elementos visuais dos seus espetáculos por meio da análise do processo de criação espacial dos cenários e dos trajes de cena, nos espetáculos $A$ Conferência dos Pássaros (1979), O Jardim das Cerejeiras (198I), A Tempestade (1990) e A Tragédia de Hamlet (200I). Documenta, indica e reflete de que forma a trajetória de evolução espiritual do encenador culminou no processo de tornar simbólicos os elementos visuais das peças, durante a concepção do espetáculo e, por meio da análise de documentos, aponta para a condução de seu teatro rumo ao teatro sagrado definido por Brook. As principais referências bibliográficas são: $O$ Espaço Vazio, Fios do Tempo e A Porta Aberta

Palavras Chaves: Cenografia. Trajes de cena. Peter Brook. Teatro Sagrado. Espaço teatral. 


\section{ABSTRACT}

The spiritual and the scene: the transformation of the set and costume design in Peter Brook's plays aims to investigate whether the search for an spiritual improvement, or what has been named the exploration of the sacred in scene, implies in the simplification of the set and costume design and the transformation of the spatial appropriation of the scenic space in the works of one of the most important theatrical directors in the 20th century, but that has also has greatly influenced the development of theatrical thoughts at the beginning of the 2 Ist century - Peter Brook, responsible for an intense research on ritual / holy theater. The work highlights the issues previously exposed about the process of simplifying the visual elements of his plays through the analysis of the process of spatial creation of set and costume designs, from The Conference of Birds (1979), The Cherry Orchard (198I), The Tempest (1990) and The Tragedy of Hamlet (200I). It documents, indicates and reflects how the stage director's spiritual evolution path culminated in the process of making the visual elements of the pieces symbolic, during the conception of the play and, through document analysis, points to the direction of his theater towards the holy theater defined by Brook. The main bibliographic references are: $O$ Espaço Vazio, Fios do Tempo e A Porta Aberta

Keywords: Set design. Costume design. Peter Brook. Holy Theater. Scenic Space. 


\section{RESUMEN}

El espiritual y la escena: La transformación del espacio escénico de los espectáculos de Peter Brook investiga si la búsqueda de la mejora de la espiritualidad, o lo que se llamó la búsqueda de lo sagrado en la escena, lo que implicaba la simplificación de la escenografía y en la transformación de la apropiación espacial y valorización del espacio escénico en las obras de uno de los directores de escena más importantes del siglo $X X$, pero también influyó al pensamiento a principios del siglo XXI - Peter Brook, responsable de una intensa investigación sobre el teatro ritualista / sagrado. El trabajo destaca los problemas previamente expuestos sobre el proceso de simplificación de los elementos visuales de sus espectáculos través de análisis del proceso de creación espacial de escenarios y vestuarios, de los espectáculos: La Conferencia de los Pájaros ( 1878), El Jardin de los Cerezos (198I), La Tempestad (1990) y La Tragedia de Hamlet (200I). Documenta, indica y refleja como la trayectoria de evolución espiritual del director de escena culminó en el proceso de hacer que los elementos visuales de las obras sean simbólicos durante la concepción del espectáculo y través del análisis de documentos señala la dirección de su teatro hacia Teatro Sagrado definido por Brook. Las principales referencias bibliográficas son: O Espaço Vazio, Fios do Tempo e A Porta Aberta

Palabras llave: Escenografía. Trajes de escena. Peter Brook. Teatro sagrado. Espacio Teatral. 


\section{LISTA DE ILUSTRAÇÕES}

\begin{tabular}{|l|l|l|}
\hline Figura I & $\begin{array}{l}\text { - Eneagrama de personalidade de } \\
\text { Gurdjieff. }\end{array}$ & 56 \\
\hline Figura 2 & $\begin{array}{l}\text { - Cena do espetáculo Ralé de Gorki, } \\
\text { encenação Konstantin Stanislávski, } \\
\text { I903. }\end{array}$ & 73 \\
\hline Figura 3 & $\begin{array}{l}\text { - Esboço do cenário do espetáculo } \\
\text { Orpheus, encenação Adolphe Appia } \\
\text { para o Festival de Hellerau de I9l3 }\end{array}$ & 79 \\
\hline Figura 4 & $\begin{array}{l}\text { - Cenário do espetáculo Orpheus, } \\
\text { encenação Adolphe Appia para o }\end{array}$ & 80 \\
\hline Festival de Hellerau de I9I3. & $\begin{array}{l}\text { Hamlet, elaborado por Craig e } \\
\text { encenado por Stanislávski. }\end{array}$ \\
\hline Figura 6 & $\begin{array}{l}\text { - O ator Andreas Katsulas na na } \\
\text { realização de um carpet show na } \\
\text { África. }\end{array}$ & 90 \\
\hline Figura 7 & $\begin{array}{l}\text { - Planta do Théâtre des Bouffes du } \\
\text { Nord antes da reforma proposta } \\
\text { por Brook. }\end{array}$ & 91 \\
\hline Figura 8 & $\begin{array}{l}\text { - Área reformada do palco do dos dos Bouffes du Nord com } \\
\text { a utilização dos balcões originais }\end{array}$ & 93 \\
\hline
\end{tabular}

\begin{tabular}{|c|c|c|}
\hline Figura 9 & $\begin{array}{l}\text { - Área de atuação com a não } \\
\text { delimitação do proscênio do palco }\end{array}$ & 94 \\
\hline Figura I0 & $\begin{array}{l}\text { - Vista do palco com duas } \\
\text { profundidades e com as paredes } \\
\text { com aspecto de destruído. }\end{array}$ & 95 \\
\hline Figura I I & $\begin{array}{l}\text { - Planta do Théâtre des Bouffes } \\
\text { du Nord com a reforma proposta } \\
\text { por Brook. Atenção para os dois } \\
\text { espaços de representação possíveis } \\
\text { após o ajuste espacial do palco. }\end{array}$ & 96 \\
\hline Figura I 2 & $\begin{array}{l}\text { - Figurino baseado na obra do } \\
\text { pintor rococó francês Antoine } \\
\text { Watteau do espetáculo Trabalho de } \\
\text { Amores Perdidos de Peter Brook. }\end{array}$ & 106 \\
\hline Figura I 3 & $\begin{array}{l}\text { - Proposta de concepção e traje de } \\
\text { cena de Lavínia em Titus Andronicus } \\
\text { (1955) direção de Peter Brook }\end{array}$ & 111 \\
\hline Figura I4 & $\begin{array}{l}\text { - Cena de Lavínia com Titus e traje } \\
\text { de Titus proposto por Heeley para } \\
\text { o espetáculo Titus Andronicus ( } 1955) \\
\text { direção de Peter Brook. }\end{array}$ & 112 \\
\hline
\end{tabular}




\begin{tabular}{|c|c|c|}
\hline Figura I5 & \begin{tabular}{|l|} 
- Imagem de Cena de Titus \\
Andronicus (1955) direção e cenário \\
propostos por Peter Brook.
\end{tabular} & 113 \\
\hline Figura 16 & $\begin{array}{l}\text { - Cena em que a coluna se } \\
\text { transforma em Floresta - Titus } \\
\text { Andronicus (1955) cenário de Peter } \\
\text { Brook. }\end{array}$ & 115 \\
\hline Figura I7 & $\begin{array}{l}\text { - Cena do banquete final - Titus } \\
\text { Andronicus (I955). Mesas e plano } \\
\text { superior em outro nível. }\end{array}$ & 116 \\
\hline Figura I8 & $\begin{array}{l}\text { - Cena em que a escada se } \\
\text { transforma em Jaula - Titus } \\
\text { Andronicus (1955) cenário de Peter } \\
\text { Brook. }\end{array}$ & 116 \\
\hline Figura I9 & $\begin{array}{l}\text { - Cena do sacrifício da borboleta } \\
\text { em U.S. (1966). }\end{array}$ & 122 \\
\hline Figura 20 & $\begin{array}{l}\text { - Proposta de cenário com diversos } \\
\text { elementos descartados em situação } \\
\text { de guerra U.S. (1966). }\end{array}$ & 124 \\
\hline Figura 21 & $\begin{array}{l}\text { - U.S. no Teatro Aldwych em } \\
\text { Londres. }\end{array}$ & 125 \\
\hline Figura 22 & $\begin{array}{l}\text { - Imagem do cenário com o } \\
\text { formato de Soldado no espetáculo } \\
\text { U.S. (1966). }\end{array}$ & 126 \\
\hline Figura 23 & $\begin{array}{l}\text { - Glenda Jackson em U.S. utilizando } \\
\text { trajes cotidianos. }\end{array}$ & 128 \\
\hline
\end{tabular}

\begin{tabular}{|l|l|l|}
\hline Figura 24 & $\begin{array}{l}\text { - Atores com adereços na cabeça } \\
\text { utilizando trajes cotidianos. }\end{array}$ & I29 \\
\hline Figura 25 & $\begin{array}{l}\text { - U.S. durante a cena de action } \\
\text { painting, I966. }\end{array}$ & 130 \\
\hline Figura 26 & $\begin{array}{l}\text { - Cenário de L'Os, evidenciando a } \\
\text { paliçada ao fundo e a utilização de } \\
\text { estruturas simples para definir os } \\
\text { espaços. }\end{array}$ & I49 \\
\hline Figura 27 & $\begin{array}{l}\text { - Trajes de cena do espetáculo } \\
\text { L'Os composição mais próxima de } \\
\text { remeter ao cotidiano da população } \\
\text { local. }\end{array}$ & 150 \\
\hline Figura 28 & $\begin{array}{l}\text { - Cartaz do espetáculo A Conferência } \\
\text { dos Pássaros (1979). }\end{array}$ & 151 \\
\hline Figura 29 & $\begin{array}{l}\text { - Figurino do pássaro exótico 2 } \\
\text { para A Conferência dos Pássaros } \\
\text { desenhado por Sally Jacobs para o } \\
\text { ator Yoshi Oida. }\end{array}$ & 153 \\
\hline Figura 30 & $\begin{array}{l}\text { Ator manipulando a Poupa } \\
\text { no espetáculo A Conferência dos } \\
\text { Pássaros (I979). }\end{array}$ & I54 \\
\hline
\end{tabular}




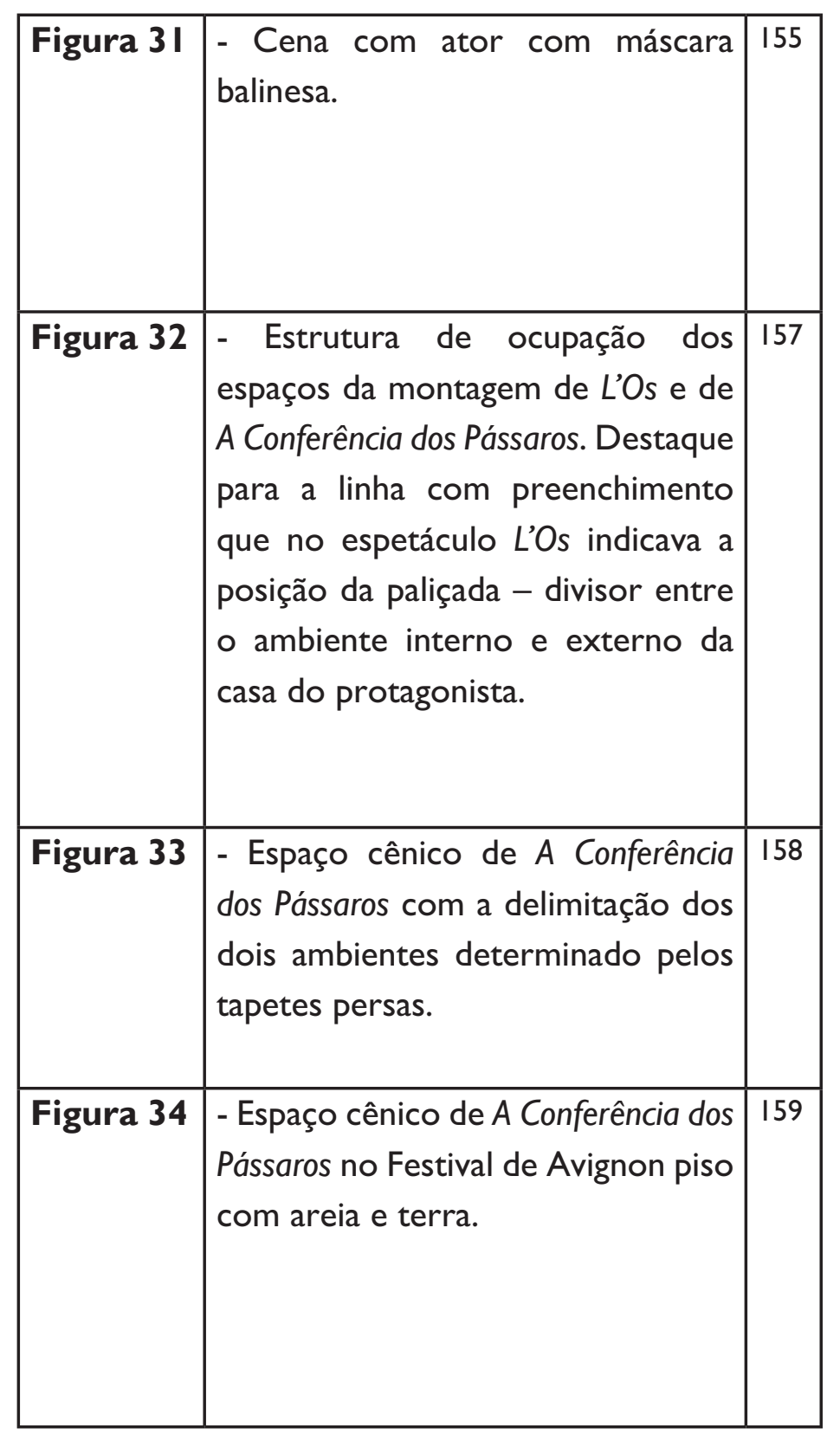

\begin{tabular}{|c|c|c|}
\hline Figura 35 & $\begin{array}{l}\text { - Figurino de A Conferência dos } \\
\text { Pássaros, ator ao centro é o Pavão e } \\
\text { utiliza um leque como instrumento } \\
\text { de reconhecimento do pássaro que } \\
\text { representa }\end{array}$ & 161 \\
\hline Figura 36 & $\begin{array}{l}\text { - Figurinos de A Conferência dos } \\
\text { Pássaros, atores utilizando a máscara } \\
\text { balinesa. }\end{array}$ & 164 \\
\hline Figura 37 & $\begin{array}{l}\text { - Cartaz de O Jardim das Cerejeiras } \\
\text { (198I) direção de Peter Brook no } \\
\text { Thêátre des Bouffes du Nord. }\end{array}$ & 178 \\
\hline Figura 38 & $\begin{array}{l}\text { - Cena de } O \text { jardim das Cerejeiras } \\
(1981) \text { em que se percebem as } \\
\text { paredes descascadas da casa de } \\
\text { Ranievskaia. }\end{array}$ & 181 \\
\hline Figura 39 & $\begin{array}{l}\text { - Cenas do segundo ato, em que é } \\
\text { possível perceber a estruturação } \\
\text { dos tapetes em cena. }\end{array}$ & 184 \\
\hline Figura 40 & $\begin{array}{l}\text { - Cena do primeiro ato de O Jardim } \\
\text { das Cerejeiras (198I) direção de } \\
\text { Peter Brook no Thêátre des Bouffes } \\
\text { du Nord. }\end{array}$ & 185 \\
\hline Figura 4I & $\begin{array}{l}\text { - Cena do segundo ato de O Jardim } \\
\text { das Cerejeiras (198I) direção de } \\
\text { Peter Brook no Thêátre des Bouffes } \\
\text { du Nord. }\end{array}$ & 186 \\
\hline
\end{tabular}




\begin{tabular}{|c|c|c|}
\hline Figura 42 & $\begin{array}{l}\text { - Cena do terceiro ato de O Jardim } \\
\text { das Cerejeiras (I98I) direção de } \\
\text { Peter Brook no Thêátre des Bouffes } \\
\text { du Nord. }\end{array}$ & 187 \\
\hline Figura 43 & $\begin{array}{l}\text { - Cena do quarto ato de O Jardim das } \\
\text { Cerejeiras (198I) direção de Peter } \\
\text { Brook no Thêátre des Bouffes du } \\
\text { Nord. }\end{array}$ & 188 \\
\hline Figura 44 & $\begin{array}{l}\text { - Esquema do cenário do } 1^{\circ} \text { e } 4^{\circ} \\
\text { atos de } O \text { Jardim das Cerejeiras } \\
(198 I) \text { no Thêátre des Bouffes } \\
\text { du Nord, desenhado por Larissa } \\
\text { Elias a partir do ensaio escrito por } \\
\text { Béatrice Picon-Vallin. } \\
\end{array}$ & 189 \\
\hline Figu & $\begin{array}{l}\text { - } \AA \text { esquerda vemos trajes } \\
\text { europeus do início do século XX } \\
\text { e à direita cena do } 2^{\circ} \text { ato em que } \\
\text { Natasha Parry traja um vestido } \\
\text { branco bastante referenciado nas } \\
\text { indicações ao lado. }\end{array}$ & 193 \\
\hline Figura 46 & $\begin{array}{l}\text { - Desenho de Peter Brook para o } \\
\text { traje de cena de Gonzalo e Cartaz } \\
\text { da montagem de Peter Brook de A } \\
\text { Tempestade (1957). }\end{array}$ & 196 \\
\hline Figura 47 & $\begin{array}{l}\text { - A Tempestade (1968) direção de } \\
\text { Peter Brook no Round House em } \\
\text { Londres. }\end{array}$ & 197 \\
\hline
\end{tabular}

\begin{tabular}{|c|c|c|}
\hline Figura 48 & $\begin{array}{l}\text { - Cartaz de A Tempestade (1990) } \\
\text { direção de Peter Brook. }\end{array}$ & 199 \\
\hline Figura 49 & $\begin{array}{l}\text { - A Tempestade (1990) cena de } \\
\text { Sotigui Kouyaté e Bakary Sangaré } \\
\text { como Ariel e Próspero na ilha de } \\
\text { areia. }\end{array}$ & 202 \\
\hline Figura 50 & $\begin{array}{l}\text { - Cena de A Tempestade (1990) em } \\
\text { que temos à frente os tripulantes do } \\
\text { navio e ao fundo Ariel e Próspero. }\end{array}$ & 203 \\
\hline Figura 5 I & $\begin{array}{l}\text { - Caliban saindo de sua célula, a } \\
\text { caixa de papelão que o assemelha } \\
\text { aos sem-teto e o corte de cabelo } \\
\text { pós-moderno com expressão } \\
\text { irritadiça. }\end{array}$ & 206 \\
\hline Figura 52 & $\begin{array}{l}\text { - Simulação de floresta realizada } \\
\text { pelos espíritos em cena de A } \\
\text { Tempestade (1990). }\end{array}$ & 208 \\
\hline Figura 53 & \begin{tabular}{|lll} 
- A Tempestade (1990) estrutura \\
do espaço de representação \\
e delimitação da área de \\
representação em adaptação do \\
espetáculo para o Teatro Ginza.
\end{tabular} & 215 \\
\hline Figura 54 & $\begin{array}{l}\text { - A Tempestade (1990) foto da } \\
\text { adaptação do espaço cênico para o } \\
\text { espetáculo no Festival de Avignon. }\end{array}$ & 215 \\
\hline
\end{tabular}




\begin{tabular}{|l|l|l|}
\hline Figura 55 & $\begin{array}{l}\text { - Figurino de A Tempestade (I990) } \\
\text { concebido por Chloé Obolensky } \\
\text { túnicas brancas simbolizam os } \\
\text { habitantes da ilha em contraste } \\
\text { direto com os náufragos. }\end{array}$ & 217 \\
\hline Figura 56 & $\begin{array}{l}\text { - À esquerda retrato de homem } \\
\text { do século XVI da época Elisabetana } \\
\text { provável inspiração de formas } \\
\text { para os trajes dos náufragos de A } \\
\text { Tempestade (I990). }\end{array}$ & 218 \\
\hline Figura 57 & $\begin{array}{l}\text { - Figurino de A Tempestade (1990), } \\
\text { cena de Ariel com os marinheiros } \\
\text { bêbados - utilização das cores } \\
\text { contrastantes - preto, brancos e } \\
\text { verdes. }\end{array}$ & 219 \\
\hline Figura 58 & $\begin{array}{l}\text { - Foto do cenário proposto para } \\
\text { A Tragédia de Hamlet (2000) no } \\
\text { Thêátre Bouffes du Nord. }\end{array}$ & 230 \\
\hline Figura 59 & $\begin{array}{l}\text { Foto do efeito de iluminação } \\
\text { quando Hamlet surpreende o rei } \\
\text { Cláudio rezando em A Tragédia de } \\
\text { Hamlet (2000). }\end{array}$ & 231 \\
\hline
\end{tabular}

\begin{tabular}{|l|l|l|}
\hline Figura 60 & $\begin{array}{l}\text { - Foto do cenário de A Tragédia de } \\
\text { Hamlet (2000) envolvendo o espaço } \\
\text { do Thêátre Bouffes du Nord no } \\
\text { drama shakespeariano. }\end{array}$ & 233 \\
\hline Figura 6I & $\begin{array}{l}\text { - Foto do cenário de A Tragédia } \\
\text { de Hamlet (2000) com o tapete } \\
\text { vermelho na diagonal e as almofadas } \\
\text { usadas em cena no Thêátre Bouffes } \\
\text { du Nord. }\end{array}$ & 235 \\
\hline Figura 62 & $\begin{array}{l}\text { - Foto do cenário proposto para A } \\
\text { Tragédia de Hamlet (2000) na cena } \\
\text { dos atores. }\end{array}$ & 239 \\
\hline Figura 63 & $\begin{array}{l}\text { - O ator Adrian Lester no solilóquio } \\
\text { 'ser ou não ser' em A Tragédia de } \\
\text { Hamlet (2000). }\end{array}$ & 242 \\
\hline Figura 64 & $\begin{array}{l}\text { - As atrizes Shantala Shivalingappa e } \\
\text { Natasha Perry como Ofélia e rainha } \\
\text { Gertrudes em A Tragédia de Hamlet } \\
\text { (2000). }\end{array}$ & 243 \\
\hline Figura 65 & $\begin{array}{l}\text { - Foto do espetáculo Fragmentos } \\
\text { (2015) - trecho de Cadeira de } \\
\text { Balanço no Théâtre des Bouffes du } \\
\text { Nord. }\end{array}$ & 249 \\
\hline
\end{tabular}


LISTA DE ABREVIATURAS E SIGLAS

\begin{tabular}{|l|l|}
\hline BAM & Brooklyn Academy of Music \\
\hline CICT & $\begin{array}{l}\text { Centre Internacional de Créations } \\
\text { Théâtrales }\end{array}$ \\
\hline ECA & Escola de Comunicação e Artes \\
\hline LAMDA & $\begin{array}{l}\text { London Academy of Music and } \\
\text { Dramatic Art }\end{array}$ \\
\hline RSC & Royal Shakespeare Company \\
\hline SESC & Serviço Social do Comércio \\
\hline UNESP & Universidade Estadual Paulista \\
\hline UNICAMP & Universidade Estadual de Campinas \\
\hline
\end{tabular}


SUMÁRIO

\section{INTRODUÇÃO}

I A ESPIRITUALIDADE EM BROOK

(1925 -)

I.I O QUE É ESPIRITUALIDADE?

I.2 RELAÇÕES ENTRE ESPIRITUALIDADE E FAZER TEATRAL - OS CASOS DE STANISLÁVSKI E GROTOWSKI

I.3 QUEM FOI GEORGE IVANOVITCH GURDJIEFF - MENTOR ESPIRITUAL DE PETER BROOK

I.4 A TRAJETÓRIA ESPIRITUAL NO TRABALHO DE BROOK

2 A ESPACIALIDADE EM BROOK E SUAS RELACÕES COM A CENOGRAFIA SIMBOLISTA

2.I AS ORIGENS DA CENOGRAFIA SIMBOLISTA

2.I.I Adolphe Appia ( $862-1928)$

2.1.2 Edward Gordon Craig ( 1872 -1966)

2.2 A MANEIRA COMO BROOK COMPREENDE CENOGRAFIA E OS TRAJES DE CENA

2.2.I A principal experiência realista simbólica de Brook - Titus Andronicus (1955)

2.2.2 Uma experiência performática U.S. (1966) 


\section{AS ORIGENS DO ESPACO SAGRADO NO TRABALHO DE PETER BROOK: A CONFERÊNCIA DOS PÁSSAROS (1979)}

3. I A CRIACÃO DO CENTRE INTERNACIONAL DE CREATIIONS THÉATTRALES (CENTRO INTERNACIONAL DE PESQUISA TEATRAL $-\mathrm{CICT}$ )

3.2 AS ORIGENS DO TRABALHO E O TEMA DE A CONFERÊNCIA DOS PÁSSAROS

3.3 A CRIACÃO DE A CONFERÊNCIA DOS PÁSSAROS (1979)

$3.4 O$ RESULTADO DOS ELEMENTOS VISUAIS: O CENÁRIO E OS TRAJES DE CENA DE A CONFEREENCIA DOS PÁSSAROS

\section{ESPAÇO CÊNICO TORNA SE PROTAGONISTA NO TEATRO SAGRADO: O JARDIM DAS CEREJEIRAS} (198I) E A TEMPESTADE (1990)

4.I AS ORIGENS DA MONTAGEM DE $O$ JARDIM DAS CEREJEIRAS E REFLEXÕES DE BROOK SOBRE TCHEKHOV

4.I.I Questões evidentes em $O$ Jardim das Cerejeiras

4.1.2 A encenação de 0 Jardim das Cerejeiras - La Cerisaie (198I)

4.1.3 O espaço de representação e os trajes de cena de $O$ Jardim da Cerejeira

4.2 AS ORIGENS DA MONTAGEM DE A TEMPESTADE (1990)

4.2.I O processo de criação de $A$ Tempestade (1990)

4.2.2 A encenação de A Tempestade (1990)
4.2.3 Processo de criacão do espaço cênico e dos trajes de cena de $A$ Tempestade.

4.3 AS RELACÕES ESPACIAIS DE O IARDIM DAS CEREJEIRAS (I98I) E A TEMPESTADE (1990)

I4I 5 TEATROSAGRADOCONSOLIDADO: A TRAGEDIA DE HAMLET (2000)

145 5.I UMA PROPOSTA SIMBÓLICA PARA A 225 TRAGEDIA DE HAMLET (2000).

I56 5.2 A SIMBOLOGIA DO, TAPETE VERMELHO 229 - CENÁRIO DE ATRAGEDIA DE HAMLET.

5.3 OS TRAJES DE CENA DE A TRAGÉDIA DE HAMLET - CONSOLIDACÃO DA SIMBOLOGIA NAS VESTIMENTAS

169

\section{CONSIDERAÇÕES FINAIS}

\section{REFERÊNCIAS}

259

APÊNDICES

Apêndice A - Tipologias de Espaço Cênico 


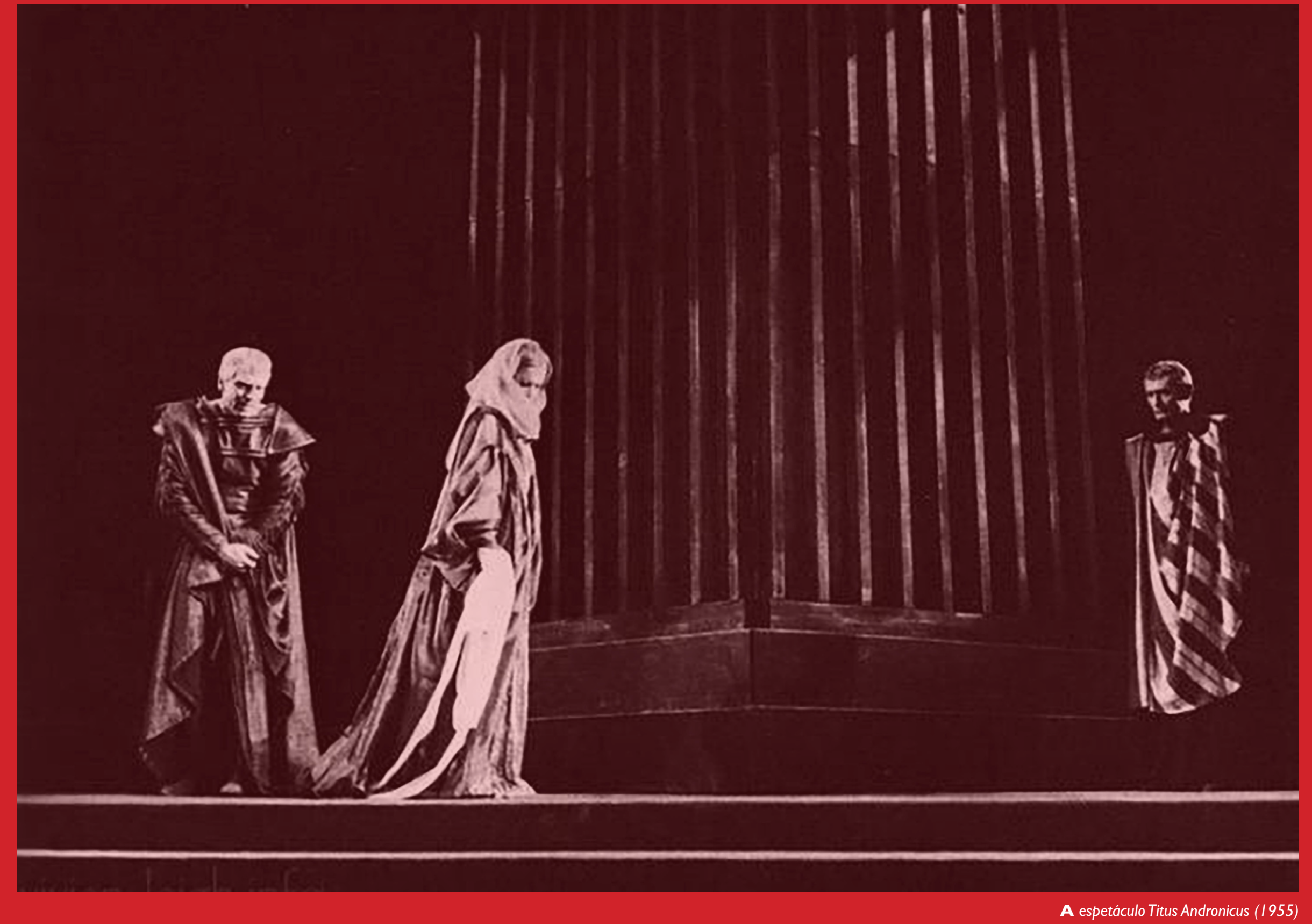





\section{INTRODUÇÃO}

As inquietações que deram origem à presente pesquisa, começaram a ser apontadas na conclusão da dissertação de mestrado', quando as problemáticas apontadas pelo Teatro Sagrado de Peter Brook ganharam significativa importância para o pesquisador. Contudo, as provocações apontadas pelo Prof. Dr. Fausto Viana, orientador de ambos os trabalhos, motivaram a investigação mais aprofundada sobre a questão da produção cenográfica, visando compreender: qual é a relação entre a simplificação dos elementos cênicos e espaciais; e, o avanço da investigação sobre as origens espirituais - ritualísticas - nos espetáculos teatrais do encenador Peter Brook.

Algumas questões permearam os objetivos dessa nova pesquisa, a saber:

- Investigar se existem pontos de tangência entre o Teatro Sagrado pretendido por Brook e a produção de outros diretores que, de algum modo, abrangem questões sobre espiritualidade em suas produções tais como Grotowski e Stanislávski.

- Buscar as interfaces estéticas em seus trabalhos e as similaridades. Investigar se é possível criar um padrão de abordagem para a implementação da simbologia na

ORTIZ, Sergio Ricardo Lessa. Do espaço vazio ao círculo aberto: rumo à cenografia e indumentária sagradas de Peter Brook. 2013. Dissertação (Mestrado em Teoria e Prática do Teatro) - Escola de Comunicações e Artes, Universidade de São Paulo, São Paulo, 2013. 
produção espacial cenográfica.

Dada a riqueza de elementos encontrados no trabalho de Brook, essa pesquisa identifica e reflete os princípios que norteiam a concepção cênica, espacial e visual de produções específicas. A partir disso, busca compreender a relação entre os resultados cenográficoarquitetônicos e a investigação sagrado-espiritual com origem ritualística no fazer teatral deste importante diretor dos séculos $\mathrm{XX}$ e $\mathrm{XXI}$.

\section{Objeto de pesquisa}

Peter Stephen Paul Brook nasceu em Londres, 2I de março de 1925, filho de pais descendentes de russos. Desde cedo tinha necessidade de expressar sua criatividade por meio de trabalhos ligados à representação. Com dezesseis anos deixou a escola para trabalhar na Crown Film Unit ${ }^{2}$, antes de ceder à pressão familiar e entrar para o Magdalen College em Oxford em 1942.

Desiludido com a falta de oportunidades para fazer teatro, fundou a Oxford Films Society a partir da realização do filme A viagem sentimental (1944) e foi expulso da universidade por este trabalho. Alguns anos mais tarde começou a atrair atenção ao realizar a peça $A$ máquina

\footnotetext{
${ }^{2}$ A Crown Film Unit tornou-se uma produtora de filmes em 1940. Fazia parte do Ministério da Informação do Governo Britânico durante a Segunda Guerra Mundial e tinha como missão realizar filmes documentais, além de documentários de produções teatrais, bem como algumas produções
} dramáticas para o público geral do Reino Unido. Foi extinta em 1952. infernal (1945); em seguida foi convidado para dirigir a Companhia de Repertório de Birmingham (1945). Embora demonstrasse grande versatilidade nos anos de 1940 e 1950 dirigindo óperas, musicais e obras de autores contemporâneos, como Arthur Miller e Jean Anouilh, foram algumas montagens de textos menos conhecidos de Shakespeare que começaram a destacálo nacionalmente.

Em 1955, durante a montagem do espetáculo Titus Andronicus protagonizado pelo renomado Sir Laurence Olivier e sua esposa Vivien Leigh, chamou a atenção de alguns críticos que o colocaram como sendo o novo destaque da direção teatral inglesa. Em 1962, ingressou na Royal Shakespeare Company (RSC), na qual dirigiu atores de grande importância internacional como Laurence Olivier, John Gielgud, Paul Scofield, entre outros. Sua montagem, violenta e cruel, de Rei Lear de Shakespeare, em 1962 com Paul Scofield como Lear, foi considerada um dos momentos importantes e decisivos em sua trajetória como diretor. Em 1964, formou um grupo experimental de pesquisa sobre Antonin Artaud intitulado Teatro da Crueldade, naquele mesmo ano realizaram a montagem de Marat-Sade de PeterWeiss.

Em 1970, a produção de Sonho de uma Noite de Verão, mágica e divertida, na RSC, abriu caminho para a criação do Centre Internacional de Créations Théâtrales (Centro Internacional de Pesquisa Teatral - CICT) em 
Paris, permitindo que o diretor mergulhasse em uma nova possibilidade de experimentação teatral. Quatro anos depois, Brook se estabeleceu no abandonado e arruinado Teatro Bouffes du Nord e realizou uma série de experimentos teatrais importantes ao utilizar atores de diferentes partes do mundo, inserindo diferentes tradições culturais em seus processos criativos, tornando-se pioneiro no que é considerado atualmente como multiculturalismo.

Dentre as montagens realizadas no Bouffes, sobressaemse: Timão de Atenas (1974) de Shakespeare; A Conferência dos Pássaros (1979), baseado num poema Sufi do século XII; O Jardim das Cerejeiras (198I) de Anton Tchekhov; a adaptação de poemas em sânscrito de Mahabharata (1985); A Tempestade (1990) de Shakespeare; O Homem que (1993) baseado no texto $O$ homem que confundiu sua mulher com um chapéu de Olivier Sacks; O terno (1999/20 I2) de Can Themba; e A Tragédia de Hamlet (2000) de Shakespeare; além de algumas peças de câmara como a versão reduzida de Carmen, de Bizet, intitulada de A Tragédia de Carmen (1991) e as óperas Pelléas et Melisande (1992) de Debussy; e, A flauta mágica (2010) de Mozart.

Ao se atentar para sua trajetória, percebe-se que Brook segue em direção ao que define como Teatro Sagrado.

Chamo-o de Teatro Sagrado por abreviação, mas poderia também chamá-lo de o Teatro do InvisívelTornado-Visível: $O$ conceito de que um palco é um lugar onde o invisível pode aparecer tem um grande poder sobre os nossos pensamentos. Todos sabemos que a maior parte da vida escapa aos nossos sentidos: a mais ponderada explicação das várias artes é que elas falam de temas que só poderiam começar a reconhecer quando se manifestam em ritmos ou em formas (BROOK, 2008, p. 57).

Além de uma vasta produção teatral, Brook tem importantes livros publicados, entre os quais destacamos: O Espaço Vazio (1968), trabalho sobre a teoria do teatro contemporâneo; $O$ Ponto de Mudança (1987), relata objetivamente seu processo de trabalho como diretor; A Porta Aberta (1993), desvenda aspectos do treinamento do ator, analisa a função do diretor, examina as funções entre texto, espetáculo e espaço; e Fios do Tempo (1998) no qual faz um relato autobiográfico intercalado com processos que discorrem sobre seu pensamento teatral.

O diretor relançou, recentemente, um de seus livros escritos em 1995: The quality of mercy: reflections on Shakespeare (2010), no qual aborda novos tópicos relativos a produção de Shakespeare, tais como: o porquê de nunca ser um autor desatualizado; a maneira como os atores deveriam se preparar para montar qualquer um de seus textos; além de questões pertinentes a algumas de suas experimentações com 
seus textos, dentre elas: Titus Andronicus, Timão de Atenas, Rei Lear, A Tempestade e Sonho de uma Noite de Verão.

No seu mais recente livro, lançado em 2017, Tip of the tongue: reflections on language and meaning, Brook coloca um olhar sobre as diferenças sutis e reveladoras entre os idiomas inglês e francês. Discorre, mais uma vez, sobre os níveis nos quais se pode apreciar as obras de Shakespeare e, também, revisita os conceitos difundidos em $O$ Espaço Vazio, no qual ele estabelece alguns apontamentos sobre as mudanças que ocorreram no teatro e no mundo desde que lançou seu primeiro livro, em 1968, sobre as questões teatrais.

\section{Justificativa}

Devido a importância de Peter Brook no cenário mundial e a existência de poucos trabalhos sobre ele no Brasil, esta tese foca no aprofundamento do processo criativo, cênico, espacial e cenográfico de algumas de suas produções. Ao buscar pesquisas desenvolvidas nas principais universidades brasileiras, encontrouse pouco material. Em geral, as dissertações e teses defendidas no país, sobre a trajetória de Brook tratam do processo de encenação com enfoque no trabalho do ator e diretor, das quais podemos citar as pesquisas de Bonfito (2009) publicada pela editora Perspectiva, que fala do processo de criação do diretor; dissertação de mestrado realizada por Castro (20I2), na UNICAMP, que trata da reflexão sobre o ator narrador no teatro de Brook; e, o trabalho de Lírio (2004, PUC-Rio) que aborda o processo de direção dos seus filmes.

Até o momento, não foi encontrada qualquer pesquisa sobre a sua produção cenográfica, além do mestrado realizado por esse pesquisador, o que ressalta o caráter inédito desta tese, a princípio, no país. Como é evidente a escassez de títulos produzidos sobre cenografia e o tratamento do espaço cênico, pretende-se, com esta pesquisa, estabelecer parâmetros e critérios de classificação para posterior avaliação de obras cenográficas, de modo que sirva de base para auxiliar novos projetos de pesquisa nessa área. Sendo assim, para melhor compreensão sobre questões relativas a cenografia, indica-se que o leitor que está se iniciando no tema, logo após o capítulo I, se direcione para a leitura do apêndice, de modo a se aprofundar sobre as questões relativas aos conceitos de espacialidade e tipologia cenográfica. Quando se relacionam as questões espaciais com as buscas ritualísticas, espirituais e sagradas da encenação, identificadas no trabalho de Brook, reitera-se a originalidade do projeto.

Conforme citado anteriormente, na conclusão da dissertação de mestrado ficou nítido que Brook conduz seu trabalho em busca de atingir o que ele define como Teatro Sagrado, ou seja, seu processo de elaboração, tanto para o espaço de representação quanto na composição dos elementos visuais - cenário e trajes de 
cena -, exclui tudo o que é desnecessário para o bom entendimento da mensagem pretendida por meio da encenação. Em suas peças, sobretudo nas mais recentes, existe uma necessidade de expressar o máximo com o mínimo de recursos, eliminando tudo o que não é o essencial para a comunicação.

A partir dessa reflexão pretende-se compreender quais são as evidências espaciais e cenográficas que representam os indícios de que quanto mais próximos do sagrado-espiritual são seus espetáculos, menos elementos cenográficos são utilizados e mais simbólicos são os resultados visuais de suas produções.

Decidiu-se, portanto, aprofundar o estudo sobre Peter Brook incorporando outros espetáculos que ressaltam a busca pelo Sagrado; e, ainda, relacionar seu trabalho com o de outros diretores teatrais, tais como: Jerzy Grotowski (1933-1999) e Konstantin Stanislávski (I8651938), que também apresentam em seus processos artístico-criativo uma relação bastante próxima com a espiritualidade.

\section{Hipótese}

Busca-se, dessa maneira, aferir se à medida em que o trabalho de direção se torna mais espiritualizado, ou seja, mais próximo do Teatro Sagrado, a necessidade de aparatos cênicos na encenação fica menor. Em sua carreira, Brook partiu de um teatro mais convencional e, ao longo dos anos, lapidou seu trabalho para chegar a uma composição cenográfica e espacial com o mínimo de elementos possível, e, portanto, mais simbólica; também, com o passar do tempo se direcionou a uma maior conexão com a espiritualidade. Desta forma, comparando as situações supracitadas, visa-se comprovar a hipótese exposta.

\section{Quadro teórico de referência}

Para Pavis (20l I), em Dicionário de Teatro, esse desejo de tornar visível o que é invisível ao ser humano- definição de Teatro Sagrado, segundo Brook - está relacionado a um processo do fim do século $X X$. Momento este em que começou a existir uma forte nostalgia quanto às origens culturais do teatro, mais ligadas ao processo ritualístico, no qual, tanto Peter Brook quanto Jerzy Grotowski e Anatoli Vassiliev, estão imersos devido à forte ligação que possuem com o resgate das raízes da representação teatral. Tudo indicava que o teatro, depois de ter se destacado do rito e da cerimônia, regressava às suas fontes, "como se uma matriz do Teatro Sagrado (Brook) fosse sua única oportunidade de sobrevivência ao contato com as artes de massa industrializadas" (PAVIS, 20I I, p. 347).

Brook define o que é o Teatro Sagrado em O Espaço Vazio, livro publicado em 1968. Reforça a existência de um mundo invisível que precisa se tornar visível. Implica na existência de algo invisível, ainda distante das formas 
que conseguimos identificar ou registrar e que contém fontes de energia extremamente poderosas. Embora não tenha que se manifestar, o invisível pode surgir em qualquer lugar, a qualquer tempo, por meio de qualquer um, desde que as condições sejam propícias.

Para Brook (2008), o invisível pode aparecer nos objetos mais banais, desde que o ator esteja em estado de receptividade e seu talento seja igualmente apurado. Sendo assim, o sagrado é, para ele, uma transformação qualitativa do que originalmente não era. Parte em busca da síntese como forma de conseguir atingir a qualidade sagrada, e alcançar uma maior objetividade na transmissão da mensagem ao público. Nunca acreditou no processo de redução do público; pelo contrário, buscou, sempre, novos modos de estimular e sacudilo para que a resposta e a transformação pudessem transcender uma experiência compartilhada no teatro.

Em seu livro A Porta Aberta, Peter Brook (2005, p. 73) coloca que:

[...] para captar um momento da verdade é preciso que o ator, o diretor, o autor e o cenógrafo, dando o melhor de si, estejam unidos em um esforço comum; ninguém pode conseguir sozinho. No espetáculo não podem existir estéticas diferentes, objetivos conflitantes. Todas as técnicas da arte e do ofício têm que estar a serviço daquilo que o poeta inglês Ted Hughes chama de "negociação" entre o nosso nível comum e o nível oculto do mito.
Ainda nesse texto, além de discutir sobre os elementos importantes para a realização teatral, relata o processo de criação da remontagem de $A$ Tempestade produzido pelo Centro Internacional de Pesquisa Teatral. E, conforme sua descrição, o espetáculo teve sua invenção semelhante a um mito cósmico, em que o diretor já teria tido, desde o princípio, um pressentimento da forma.

Sobre a espiritualidade destaca-se, na base do trabalho de Peter Brook com o sagrado, os ensinamentos conceituais de George Ivanovitch Gurdjieff, místico e mestre espiritual greco-armênio, cujos preceitos Brook começou a seguir seus preceitos após a leitura de Fragmentos de um ensinamento desconhecido: em busca do milagroso ${ }^{3}$, de Ouspensky (2016). Esta publicação é reconhecida como o relato mais valioso e confiável sobre os pensamentos e ensinamentos de Gurdjieff, cuja obra é considerada, por muitos, como a base do pensamento místico no Trabalho. Traz à luz uma combinação de filosofias orientais, transmitidas oralmente aos seus discípulos por séculos.

Com o intuito de divulgar esse conhecimento ao Ocidente, Gurdjieff apresenta o Trabalho, por meio da transcrição realizada por Ouspensky. Nessa obra descreve os ensinamentos em detalhes, de maneira

3 Título original em inglês: In Search of the Miraculous - Fragments of an Unknown Teaching. 
bastante acessível, proporcionando uma introdução à visão de seu mestre. Esse texto foi responsável, também, por inspirar pensadores e escritores adeptos a movimentos espirituais de vanguarda.

Outro texto relevante relacionado à pesquisa espiritual do encenador é $O$ trabalho de Gurdjieff de Kathleen Speeth (1976), psicóloga e discípula de Gurdjieff. É um livro que relata tanto a vida quanto a obra e filosofia desse notável e enigmático mestre espiritual. Apresenta algumas teorias relativas a Gurdjieff tais como: o processo de fragmentação dos seres humanos; o estudo da consciência em busca de meios mais elevados; e, a indicação dos quatro caminhos para a elevação espiritual.

O texto intitulado $O$ sagrado e o profano: a essência das religiões, de Eliade (1992), esclarece como as crenças espirituais continuam a influenciar os pensamentos e atitudes das pessoas, mesmo em uma sociedade tão modificada ao longo de sua trajetória histórica. Nesse sentido, trata o sagrado em oposição ao profano, e compreende o sagrado como uma fé em algo maior, em algo que existe para além da materialidade imediata do mundo.

Esse "sagrado" se revela no mundo por meio de determinados sinais e elementos, os quais são chamados hierofanias. Seu objetivo é compreender:
[...] de que maneira o homem religioso se esforça por manter-se o máximo de tempo possível num universo sagrado e, consequentemente, como se apresenta sua experiência total de vida em relação à experiência do homem privado de sentimento religioso, do homem que vive, ou deseja viver, num mundo dessacralizado (ELIADE, I992, p. 16).

A obra de Hadot (20I4), Exercícios espirituais e filosofia antiga, traz uma série de ensaios, artigos, conferências e comunicações, publicadas pelo autor em 1993. A importância do estudo dos exercícios espirituais da Antiguidade é tal que, seu objetivo é, sobretudo, o "de especificar todo o alcance e a importância desse fenômeno e mostrar as consequências que dele decorrem para a compreensão do pensamento antigo e da própria filosofia" (HADOT, 20I4, p. 2I). No compilado de textos, o autor revela sua trajetória de pensamento, as preocupações que o levaram a formular sua principal tese e os motivos pelos quais certos filósofos impregnaram seu pensamento. Ou seja, para Hadot (2014) a Antiguidade distinguia claramente a existência de uma vida filosófica, a dizer, uma filosofia vivida e praticada, e a existência de um discurso filosófico que servia tanto para justificar como moldar essa escolha de vida.

\section{Objetivos principais}

O objetivo principal é investigar a concepção espacial- 
cenográfica e sua relação com o teatro ritualísticoespiritual, com foco na trajetória profissional de Peter Brook que recorre à utilização do mínimo de recursos, valendo-se do uso da imaginação do espectador e da simbologia, de modo a estabelecer, assim, a comunicação teatral. Para atingir tal objetivo, pretende-se:

- estabelecer parâmetros qualitativos e critérios para a avaliação dos projetos cenográficos elaborados pela equipe de Brook;

- compreender e relacionar as soluções espaciais e cenográficas de Peter Brook mediante a análise de alguns dos seus espetáculos, a saber: A Conferência dos Pássaros (1979), O Jardim das Cerejeiras (I98I), A Tempestade (1990) e A Tragédia de Hamlet (2000);

- discutir e comparar o processo de criação espacial nos espetáculos de Brook com diretores como Grotowski e Stanislávski, identificando possíveis semelhanças e diferenças entre as soluções espaciais e cenográficas observadas em seus espetáculos;

- reorganizar o material (fotográfico e teórico) pertinente às produções teatrais a serem analisadas, promovendo a reunião dessa produção de maneira a facilitar o acesso e, também, conhecimento público deste material no Brasil, uma vez que, como dito, no país esse material, é muito escasso;

- analisar e refletir sobre os resultados cenográficos e espaciais dos espetáculos, de modo a confirmar as relações entre a simplificação dos elementos cênicos e o aumento da sofisticação da encenação respaldada pelo ganho simbólico nestas encenações de cunho mais espiritual.

\section{Procedimentos Metodológicos}

Este projeto caracteriza-se, do ponto de vista metodológico, por estabelecer relações entre as produções espaciais e cenográficas de Peter Brook e o processo de simplificação dos elementos cenográficos em decorrência de uma maior espiritualização da cena, a partir do estudo de algumas das suas montagens.

Para a definição do diretor a ser estudado estabeleceramse alguns critérios:

- preferência pessoal pelo estilo do encenador;

- a importância teórica, ou seja, que sua produção tenha instigado outros pesquisadores a produzirem material teórico sobre ele;

- a criação teatral com repercussão mundial, e produção com diversos espetáculos;

- sua produção estivesse relacionada com a busca de um teatro ritualístico-espiritual;

- seus espetáculos utilizassem cenários e/ou intervissem 
no espaço da representação teatral.

De modo a identificar as questões sugeridas pela hipótese levantada, decidiu-se aprofundar a análise dos seguintes espetáculos: A Conferência dos Pássaros (1979), O Jardim das Cerejeiras (1981), A Tempestade (1990) e A Tragédia de Hamlet (2000). Estas peças foram escolhidas justamente devido ao fato de se distribuírem ao longo do tempo na obra de Peter Brook, o que possibilita abranger sua trajetória permitindo a comparação dos processos cenográficos e dos trajes de cena entre elas.

Sendo assim, foi realizado para a elaboração desta tese:

- levantamento da produção de Brook, com pesquisa na biblioteca da ECA-USP, onde se encontra, no Brasil, a maior parte do material publicado a respeito do diretor em livros, textos, além de folhetos, gravações e fotografias sobre seu trabalho. A pesquisa também abrangeu as bibliotecas do SESC-SP, UNESP e UNICAMP, assim como acervos particulares.

- a partir da leitura do material coletado investigouse as suas produções. Com a organização de dados iconográficos e históricos, promoveu-se a sistematização das questões que remetiam tanto ao tema do teatro ritualístico, quanto identificou-se o processo criativo espacial e visual dos espetáculos em análise.

-Discutiu-se sobre o processo de criação espaçialvisual dos espetáculos, identificando as soluções estéticas e espaciais e comparando seus resultados com os processos de investigação espiritual de demais encenadores, tais como Konstantin Stanislávski e Jerzy Grotowski, que tem pontos em comum a questão do processo ritual e aprimoramento individual em seus espetáculos;

- finalmente, a redação do documento síntese do trabalho realizado, aproximando e entrecruzando as questões enunciadas com as observações discutidas de forma a expor o processo criativo e estabelecer relações entre as produções, seus resultados estéticos e o processo de espiritualização da cena.

No capítulo I, o objetivo é refletir, brevemente, sobre o processo de desenvolvimento espiritual de Brook, ponderando sobre a maneira como as orientações de seu mentor, Gurdjieff, podem ser apontadas nos seus trabalhos, bem como de que forma a presença da espiritualidade aprimorou a visão do diretor sobre a sua expressão artística.

No capítulo II, inicia-se a discussão sobre a transformação da cenografia com os artistas simbolistas, especialmente aqueles que foram responsáveis pela transformação da cena, tais como, Gordon Craig e Adolphe Appia. Na sequência vem a apresentação das reflexões de Peter Brook acerca da concepção espacial do seu trabalho, um dos pontos focais desta pesquisa, nas quais o diretor estabelece alguns pontos de tangência com as questões 
da cenografia simbolista; desenvolvida como resposta ao estilo teatral vigente no final do século XIX.

Apresentam-se, ainda, as ideias de Brooksobre cenografia e indumentária; mostrando-se, também, a evolução da concepção espacial do diretor com dois espetáculos significativos em sua trajetória, nos quais é possível identificar algumas reflexões sobre a transformação na concepção do espaço cênico. Para tanto, discutese dois espetáculos: Titus Andronicos (1955) com a sua principal experiência realista simbólica; e, depois, com U.S. (1966) o exercício performático de Brook.

No capítulo III, pretende-se compreender o início do processo de investigação sobre o Teatro Sagrado e seu aprofundamento sobre as questões simbólicas, quando Brook já está estabelecido em Paris com a fundação do CICT. Neste capítulo será analisado um dos espetáculos mais significativos do princípio do trabalho do diretor com o Centro Internacional de Pesquisa Teatral: A Conferência dos Pássaros (1979).

No capítulo IV, identificou-se nos espetáculos 0 Jardim das Cerejeiras (198I) e A Tempestade (1990) que o espaço cênico ganhou um maior protagonismo no processo de criação do diretor. A análise destas duas

${ }^{4}$ Sulfi é proveniente de sufismo (do árabe) que é conhecida como a corrente mística e contemplativa do Islã. Os praticantes do sufismo, conhecidos como sufis, procuram desenvolver uma relação íntima, direta e contínua com Deus, utilizando-se das práticas espirituais transmitidas pelo profeta Maomé, com orações e jejuns. Também faz parte da cultura práticas, como cânticos, música e movimentos. montagens é muito oportuna, de modo a compreender quais transformações ocorreram desde a montagem do poema sulfí, A conferência dos Pássaros, relatado no capítulo anterior.

Por fim, no capítulo $\mathrm{V}$, parte-se para a análise dos momentos de consolidação do conceito de Teatro Sagrado apontados por Brook. É o momento de identificar como esta consolidação ocorreu na concepção espacial e cenográfica do espetáculo $A$ Tragédia de Hamlet (2000).

Nos apêndices, destacam-se alguns parâmetros para a avaliação do espaço cênico, de modo que seja possível identificar as questões dos símbolos na concepção espacial, para finalmente permitir as reflexões sobre - processo de criação espacial e cenográfico dos espetáculos do diretor inglês. 


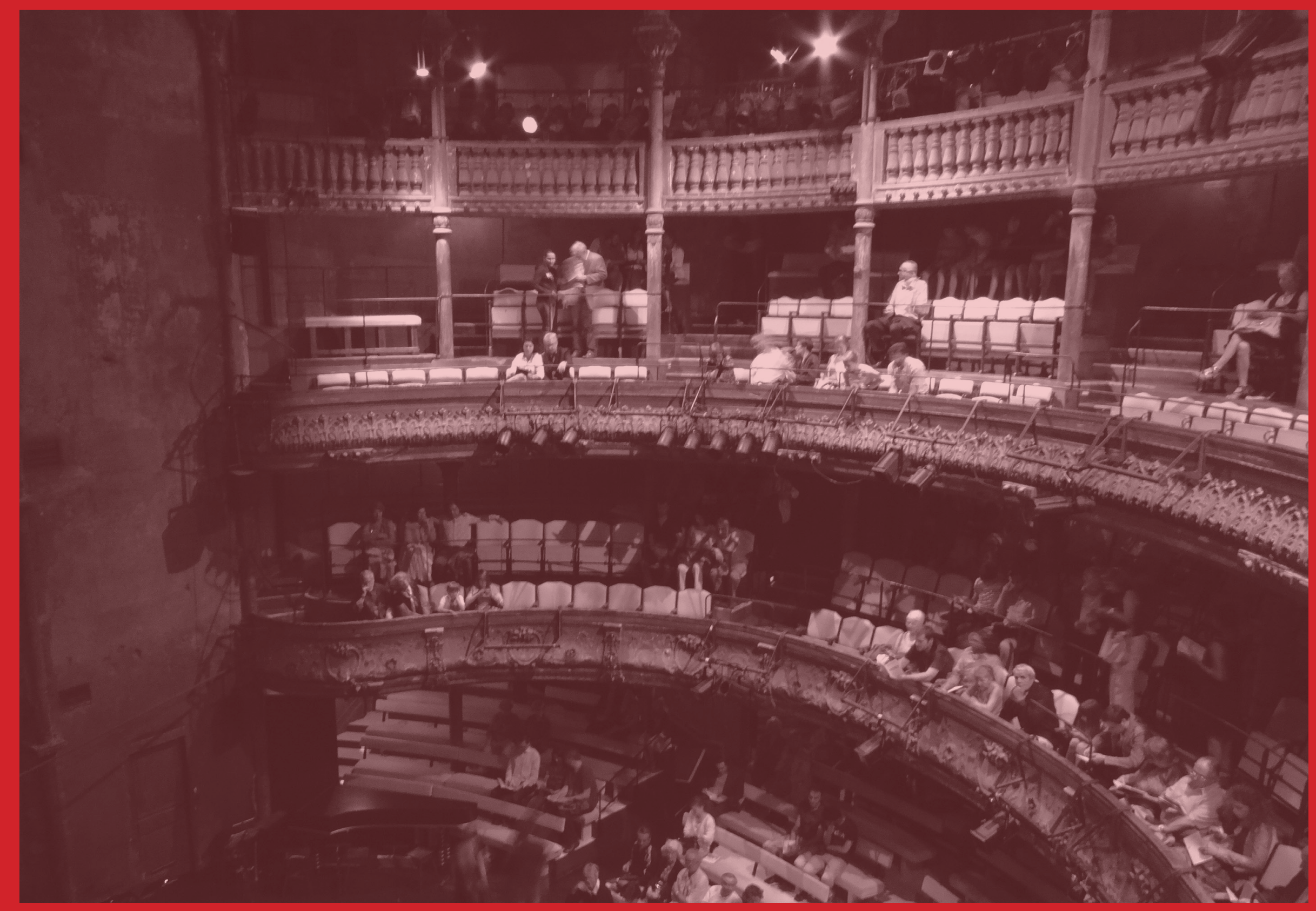





\section{A ESPIRITUALIDADE EM BROOK}

(1925 -)

Um dos principais objetivos é compreender se à medida que o trabalho de Peter Brook se torna mais espiritualizado, ou seja, mais próximo do que ele próprio define como sagrado, existe uma alteração significativa no processo de criação dos cenários e trajes de cena que, por sua vez, evidenciam uma menor necessidade de aparatos cênicos para evidenciar a mensagem teatral. Desse modo, este capítulo traz à discussão a questão do que é espiritualidade e quais são as principais diferenças com a questão da fé religiosa.

$\mathrm{Na}$ sequência, são apresentados outros diretores de teatro que, assim como Brook, tiveram também uma relação significativa com a questão do sagrado e da evolução do ser humano no processo de concepção teatral. Desse modo, expõe-se, brevemente, a maneira como a questão do ritual e a evolução espiritual interferiram nas pesquisas de Konstantin Stanislávski e Jerzy Grotowski, uma vez que ambos tiveram alguma relação com a concepção teatral de Brook.

Por fim, relata-se, de maneira concisa, a história do mentor espiritual de Brook, bem como os principais pontos de sua base filosófica que interferiram diretamente na trajetória do diretor inglês. Busca-se, portanto, indicar como Brook identifica as questões espirituais e de que maneira o contato com a metafísica 
influenciou as suas decisões e interferiu nos seus espetáculos, para que seja possível verificar estas questões nas peças analisadas nos capítulos seguintes.

\section{I.I O QUE É ESPIRITUALIDADE?}

Brook define o conceito de Teatro Sagrado em 0 Espaço Vazio, livro publicado em 1968, no qual reforça a existência de um mundo invisível que precisa se tornar visível. Para ele, o palco era o lugar onde o invisível podia aparecer e ter um enorme poder sobre os pensamentos dos espectadores. De acordo com sua definição:

Implica na existência de algo mais embaixo, em volta e acima, uma outra zona, ainda mais invisível ainda mais distante das formas que conseguimos identificar ou registrar, e que contém fontes de energia extremamente poderosas. Ela não se comunica por sons ou ruídos, mas através do silêncio (BROOK, 2005, p. 49).

A partir dessa afirmação, coloca-se uma questão importante: o sagrado é uma forma? De acordo com Brook (2005), as religiões entraram em declínio quando quiseram conferir à energia, à luz - que não têm forma - um aspecto definido, cujo significado se perde, rapidamente, tais como as cerimônias, os rituais e os dogmas. O problema, segundo o autor, é que o invisível não precisa se tornar visível.

O invisível pode aparecer nos objetos mais banais. Uma garrafa de plástico ou um pedaço de pano; pode se transformar e impregnar-se do invisível, desde que $o$ ator esteja em estado de receptividade e seu talento seja igualmente apurado. Por exemplo, um grande dançarino indiano pode tornar sagrado o mais profano dos objetos. O sagrado, assim colocado, é uma transformação qualitativa do que originalmente não era. E o teatro, por sua vez, baseia-se em relações entre seres humanos que, por serem humanos, não são sagrados, por definição (BROOK, 2005).

A consciência de que existem realidades mais sutis surgiu em algum momento da evolução humana, quando o ser humano teve contato com outras dimensões de realidade que excediam a forma como percebiam sua situação. Assim, em culturas e épocas distintas, permaneceu a busca por meios e caminhos que possibilitassem o contato com essas realidades. Surgiram os rituais, no momento em que os seres humanos descobriram maneiras e procedimentos para facilitar o seu contato com o desconhecido, ao qual as religiões se referem como esfera espiritual. Em diferentes culturas e em épocas distintas, inicia-se a possibilidade de estabelecer codificações para estes procedimentos.

Pavis (20II) indica que o surgimento do teatro é proveniente de uma cerimônia religiosa, ou seja, de um grupo de pessoas que se reunia para celebrar um rito agrário ou de fertilidade. Nesse início, ao menos, 
o teatro não era compreendido como um espetáculo, embora já apresentasse elementos pré-teatrais como "trajes dos oficiantes e vítimas humanas ou animais; a escolha de objetos simbólicos; [...], simbolização de um espaço sagrado e de um tempo cósmico e mítico, de outra natureza, pois que os dos fiéis." (PAVIS, 20I I, p. 345). Esse encontro, embora não fosse assimilado como uma encenação em que o público fosse assistir por prazer, tratava-se de uma experiência catártica, isto é, de uma experiência espiritual transformadora.

"A separação dos papeis entre os atores e espectadores, o estabelecimento de um relato mítico, a escolha de um lugar específico para esses encontros, institucionalizam pouco a pouco o rito em acontecimento teatral" (PAVIS, 20I I, p. 346). Por meio da catarse foi que se despontou o teatro, como forma de trazer a reflexão e ajudar o ser humano a compreender o porquê de sua existência, por exemplo. De acordo com Berthold (2000), o teatro dos povos primitivos estava embasado nos encantamentos de caça, nas danças de fertilidade e colheita, nos ritos de iniciação e nos vários cultos divinos.

A forma e o conteúdo da expressão teatral são condicionados pelas necessidades da vida e pelas concepções religiosas. Dessas concepções um indivíduo extrai as forças elementares que transformam o homem em um meio capaz de transcender-se e a seus semelhantes
[...] O homem personificou os poderes da natureza. Transformou o Sol e a Lua, o vento e o mar em criaturas vivas que brigam, disputam e lutam entre si e que podem ser influenciadas a favorecer o homem por meio de sacrifícios, orações, cerimônias e danças [...] Não somente os festivais de Dioniso da antiga Atenas, mas a Pré-história, a história da religião e folclore oferecem um material abundante sobre danças rituais $\mathrm{e}$ festivais das mais diversas formas que carregam em si as sementes do teatro (BERTHOLD, 2000, p. 2).

Dessa maneira, os laços que unem o teatro às crenças religiosas se estabeleceram desde as origens do ser humano. Nas tribos xamanísticas, os sacerdotes, por meio dos rituais, são responsáveis por extrapolar os limites do corpo humano para alcançar o poder metafísico. Exibiam-se com os corpos pintados, trajando vestimentas especiais: apresentavam-se como se estivessem possuídos pela entidade da qual eram instrumento. Por intermédio deles, os deuses se comunicavam, executando comportamentos incomuns para os seres humanos.

Este sacerdote/ator primitivo é, ao mesmo tempo, condutor e mecanismo de recepção de mensagens metafísicas expostas em uma cerimônia carregada de teatralidade para atingir os fiéis/espectadores. Com o passar dos anos, tanto no Ocidente como no Oriente, a ligação da arte com o mundo espiritual permaneceu 
presente, não somente quando há a mensagem relativa à temática do sagrado.

No Japão, segundo Berthold (2000), o teatro também teve suas origens no conflito dos poderes sobrenaturais dos deuses. Tanto que o teatro Nô, um dos mais tradicionais do país, se encaixa inteiramente na estética samurai baseada no zen-budismo. Assim, as artes, de modo geral, no país, permaneceram compreendidas como caminhos de espiritualidade. Conforme observa o monge e filósofo Pinto (20l5), tanto para quem cria, como para quem admira a arte, buscava-se, através do visível, vislumbrar algo sagrado que existisse em outra dimensão, no âmbito do invisível.

Contudo, no Ocidente, os avanços científicos e tecnológicos, sobretudo a partir do lluminismo, fizeram com que a conexão das artes com o mundo espiritual fosse esquecida, ignorada e, outras vezes, até questionada e negada. Pavis (20 I I, p. 346), em Dicionário do Teatro, relaciona a questão do processo ritualístico no teatro contemporâneo, afirmando que há:

[...] uma forte nostalgia de suas origens culturais, agora que a civilização parou de pensar em si mesma como única e superior, e abriu seus horizontes a culturas extra europeias, em cuja vida social o rito ainda tem um papel importante. [...] Portanto, o ritual encontra seu caminho na apresentação sagrada de um acontecimento único: ação não imitável por definição, teatro invisível ou espontâneo, mas sobretudo, desnudamento sacrificial do ator (em Grotowski ou Brook) diante do espectador que coloca assim suas preocupações, bem como as profundezas de sua alma, à vista de todos, com esperança confessa de uma redenção coletiva. Muitas encenações retomam a "missa em cena": rito do sacrifício do ator, da passagem a um estado de consciência superior, submissão à repetição infindável e ao serialismo, obsessão da imobilidade ou da performance única, desejo de tornar visível o invisível, crença numa mudança política ao termo da morte ritual do indivíduo, obsessão pela participação do público no cerimonial cênico. Quaisquer que sejam as manifestações, sempre existe esse desejo de voltar às fontes da qual Grotovski, em seu Teatro das Origens, etapa importante de sua busca, se tornou figura emblemática.

Eliade (1992), professor, filósofo e mitólogo naturalizado norte-americano, em seu livro $O$ sagrado e o profano, expõe o conceito de sagrado. Inicialmente o define a partir da oposição com o que seria o profano. Em seguida, explica que o sagrado se revela a partir da fé em algo maior; ou seja, algo que existe para além da materialidade imediata do mundo em que vivemos. Assegura, também, que o sagrado se manifesta sempre como uma realidade bastante diferente das realidades "naturais", por meio de determinados sinais e elementos, os quais denomina de hierofanias. De acordo com a 
etimologia da palavra, hierofanias, exprime que "algo de sagrado nos é revelado"5 (ELIADE, 1992, p. 15).

Segundo o filósofo, "o sagrado e o profano constituem duas modalidades de ser no Mundo, duas situações existenciais assumidas pelo homem ao longo de sua história" (ELIADE, 1992, p. 20). Portanto, esses dois conceitos estabelecem polaridades sobre dois modos de vida, sobre a concepção do mundo e da existência. São complexos arranjos socioculturais que não abrangem somente crenças e rituais, como qualquer sistema de moral, ética, códigos, símbolos, filosofia e organização social.

Conforme indica Eliade (1992), para os povos antigos o sagrado não era uma crença longínqua, mas a realidade, que estava presente a todo instante nos rituais $\mathrm{e}$ celebrações, constituindo uma parcela essencial dos costumes e crenças das sociedades antigas. Pode-se tomar por exemplo, a ocupação de um território. De acordo com o mitólogo, para alguns povos primitivos a ritualização inaugura a ocupação do território, e o torna uma "habitação sagrada". Desse modo é a presença de totens e colunas de pedra com inscrições que tornam possível a apropriação do terreno.

Tanto o totem, como a coluna de pedra, ou uma árvore sagrada não são adoradas por serem simples objetos, mas justamente porque são hierofanias. Elas "revelam"

${ }^{5}$ No original: que algo de sagrado se [sic] nos releva. algo que já não é nem o totem, nem a pedra, nem árvore, mas o sagrado. Ao manifestar o sagrado, um objeto qualquer se torna outra coisa, e, apesar disso, também continua a ser ele mesmo. Uma pedra sagrada não deixa de continuar sendo uma pedra. Para ter maior exatidão do ponto de vista profano, aparentemente não existe distinção entre ela e todas as demais pedras.

Em realidade, esse conjunto de práticas e crenças que simbolizam a experiência do sagrado, atualmente são postas em dúvida, uma vez que o mundo contemporâneo decidiu viver em um mundo dessacralizado, que questiona o sagrado, a crença, e a existência de algo divino, maior do que o próprio homem/indivíduo. Apesar desta atitude, Eliade (1992) visa apontar exemplos de que ainda existem resquícios do homem religioso, em nossas atitudes mais banais, tal como quando se bate na madeira para afastar a má sorte.

Eliade também define o espaço e o tempo sagrados. Para ele, a fim de que haja uma "revelação de uma realidade absoluta” (ELIADE, 1992, p. 22), em contraposição à nossa realidade que é bastante fraturada, é preciso que o espaço sagrado não permaneça homogêneo. $O$ mundo que se conhece (o espaço profano) é composto por uma massa amorfa de uma infinidade de lugares neutros em que o ser humano se move e cumpre com as obrigações de sua existência na sociedade industrial que se vive. Desse modo, para que se reestabeleça o 
espaço sagrado, é preciso que haja a criação de um centro, um ponto fixo absoluto, de onde se organiza a orientação ritual.

Trata-se de um local consagrado e à parte da esfera profana, o qual é derivado de uma hierofania, destacando-se do meio que o envolve. Assim, se torna qualitativamente distinto. Ao se estabelecer esse tipo de ambiente, evidencia-se o espaço limiar - o lugar de fronteira onde estes universos se comunicam, que estabelece uma simbologia relacionada com a possibilidade de passagem de um espaço ao outro. Dessa maneira, o ser humano reestabelece o espaço sagrado à medida em que reproduz a obra dos deuses.

Da mesma maneira, para o filósofo americano, o tempo sagrado também não é homogêneo e não apresenta continuidade. É possível percebê-lo somente em alguns intervalos de tempo, nas ocasiões das festas relacionadas com as questões sacras, ou durante as liturgias. Sendo assim, o tempo sagrado é reversível, uma vez que é possível trazê-lo novamente a cada vez que o ritual ou festa seja realizado. Portanto, é circular e pode ser periodicamente instaurado para que seja possível aproximar os homens das ações divinas.

Outro meio de abordar a questão é tentar distinguir a questão da espiritualidade como ligada ao campo da religião, que apesar de muitas vezes serem tratados e utilizados como sinônimos, na realidade possuem conceitos distintos. Religiosidade, provém de religião compreendida como culto prestado à divindade, reverência e respeito, bem como um grupo ou sistema de crenças que envolvem o sobrenatural, sagrado ou divino e, geralmente, está associada a códigos morais, instituições, práticas, valores e rituais próprios. Vale ressaltar que nesse contexto ainda mantém o sentido de busca pela "verdade" (em sentido análogo ao da espiritualidade), e de transformação da pessoa. Todavia, no caso das religiões ocidentais o sagrado assume a forma de Deus.

Ao passo que espiritualidade trata daquilo que é da natureza do espírito, místico e incorpóreo. Engloba, conforme expresso anteriormente, as necessidades humanas universais, que por sua vez, podem ou não estar associadas a alguma crença. Evoca um estado de busca interna e de propósito de vida, e ainda pode abranger uma dimensão complexa da experiência humana que se relaciona com o imaterial. Mas, certamente, fornece uma filosofia ou perspectiva, de modo a nortear as escolhas do indivíduo.

Hadot (20 I4), filósofo, historiador e filólogo francês, em seu livro Exercícios espirituais e filosofia antiga, indica uma problemática relacionada a adoção da palavra espiritual no sentido contemporâneo, sobretudo para definição do termo exercícios espirituais, uma vez que:

A palavra "espiritual" permite entender bem que esses exercícios 
são obra não somente do pensamento, mas de todo o psiquismo do indivíduo e, sobretudo, ela revela as verdadeiras dimensões desses exercícios: graças a eles, o indivíduo se eleva à vida do Espirito objetivo, isto é, recoloca-se na perspectiva do Todo ("Eternizar-se ultrapassando-se”) (HADOT, 20I4, p. 20).

Para ele, a espiritualidade está diretamente relacionada com a transformação do sujeito e da sua visão de mundo. Por meio da filosofia, o ser humano passa de um estado de vida obscurecido pela inconsciência, para um estado de vida autêntico, "no qual o homem atinge a consciência de si, a visão exata do mundo, a paz e a liberdade interiores" (HADOT, 20I4, p. 22). Para todas as escolas filosóficas, as causas de desordem, sofrimento e medos exagerados do ser humano eram as paixões e suas preocupações, que o impediam de viver verdadeiramente.

Compreende os exercícios como sinônimos da filosofia. Esses, por sua vez, de acordo com a escola helenística, consistiam na melhoria do ser em um processo de aprimoramento de si, de uma mudança radical. Ao passo que o exercício espiritual significa a transformação profunda na maneira de ver e de ser do indivíduo. Para a filosofia antiga, um exercício é: "um ato que não se situa apenas na ordem do conhecimento", é uma "conversão que subverte toda a vida, que muda o ser daquele que a realiza" (HADOT, 20I4, p. 22).
No texto Grotowski, A arte como veículo, Brook (200 I, p. 37) conceitua a busca pelo espiritual:

A partir do momento em que alguém começa a explorar as possibilidades do ser humano, é preciso simplesmente aceitar o fato de que essa pesquisa é uma busca espiritual [...]. Eu entendo "espiritual" no sentido que, assim que a gente se inclina para a interioridade do homem, a gente passa então do domínio do conhecido ao do desconhecido.

Desse modo, a espiritualidade a qual se refere o diretor inglês, não está ligada a qualquer seita ou religião; logo, trata-se da pesquisa daquilo que é humano, ou do que seria o ser humano, ou ainda, das potencialidades de cada um. Em seu livro Avec Grotowski, Brook (200I) indica que a busca do sagrado na arte de representação está no desejo de alcançar o sagrado, e que, para isso, há a dependência do aprimoramento do ator. Para Brook, o trabalho do ator é obra de uma vida, em que o ator paulatinamente expande o conhecimento que tem de si mesmo por meio de situações dolorosas, mas sempre renovadoras, de modo que possa adquirir uma maestria técnica de seus meios físicos e psíquicos.

Ao falar sobre o desenvolvimento do trabalho de Grotowski, relata:

[...] que eu saiba, nenhuma outra pessoa no mundo, ninguém depois de Stanislávski, explorou a natureza do jogo do ator, o fenômeno que o constitui, seus sentidos, a ciência 
dos processos, tanto psíquico quanto físicos ou emocionais, tão profundamente e plenamente quanto Grotowski (BROOK, 20II, p. 15).

Sugere que Grotowski também apresenta o desejo de alcançar o sagrado e vai além, colocando o teatro como um veículo, um meio de análise, uma possibilidade de salvação. Seus atores trabalham invocando e revelando aquilo que está adormecido na alma de cada ser humano e que a vida cotidiana serviu para mascarar. Assim, para Brook (20I I), o teatro desenvolvido pelo diretor polonês é sagrado, pois seu objetivo é sagrado.

Por meio de uma expressividade física, levada aos limites extremos, é possível reconhecer a unidade daquilo que é espiritual e corpóreo. Dessa maneira, o artista não estaria envolvido somente como profissional, mas como sujeito em seu ofício teatral e, assim, envolto em um trabalho espiritual. De tal modo, o trabalho desse ator estabelece uma relação com a definição de Stanislávski, relativo ao trabalho do ator sobre si mesmo, que será abordada adiante.

\section{I.2 RELAÇÕES ENTRE ESPIRITUALIDADE E FAZER TEATRAL - OS CASOS DE STANISLÁVSKI E GROTOWSKI}

O encenador britânico afirma categoricamente que não leu quase nada sobre as teorias de Stanislávski em entrevista a Croyden (2003), pois queria permanecer livre de qualquer uma delas. Não se sentia interessado e 40 nem mesmo acreditava que seu conhecimento o ajudaria no aprimoramento do seu processo. Seu conhecimento sobre método do encenador russo indicado em $O$ espaço vazio, era de que os atores treinados pelo método recusavam imitações estereotipadas da realidade, pois procuravam algo mais real em si mesmos.

Portanto, era necessário que os atores efetivamente vivenciassem a situação nas apresentações. Logo, a representação se tornou profundamente naturalista. A realidade, nesse sentido, era compreendida como parte integrante e efetiva das circunstâncias que envolviam tanto as pessoas como o contexto do ator em cena. Esse também era o contexto dos dramaturgos contemporâneos a ele, o teatro stanislavskiano correspondia exatamente aos anseios dos melhores clássicos russos ao representá-los de forma naturalista.

Brook (1994) tece algumas críticas ao revelar que o diretor russo foi desafiado por seu discípulo Meyerhold a pensar em um estilo distinto de representação que buscasse evidenciar outros elementos da "realidade". Mesmo assim, reconhece em, seu livro Ponto de Mudança, que teatro para o encenador russo "é humanidade" (BROOK, 1994, p. 68). Considerando os comentários que Brook acabou de revelar sobre Stanislávski, deve-se ressaltar que o encenador inglês realmente não tem um profundo conhecimento sobre o diretor russo, uma vez que não se aprofundou nas 
pesquisas que revelam uma conexão de Stanislávski com o desenvolvimento espiritual.

Stanislávski revolucionou o mundo das artes cênicas com novas teorias teatrais e com a criação de um método próprio de interpretação para atores. Em Nenhum manual ou gramática da arte teatral: alguns apontamentos sobre a formação do sistema de Stanislávski, Eleva Vássina (2013), pesquisadora e professora russa, explica que existe muito material sobre o sistema stanislavskiano, mas, de fato, Stanislávski conseguiu enviar somente uma parte dos seus textos para a edição. $O$ restante do material foi reunido por outros pesquisadores e pessoas ligadas ao diretor com base nos materiais e arquivos dele.

Sendo assim, é provável que existam algumas edições e alterações no Sistema proposto pelo encenador. Tornase importante, portanto, uma pesquisa diretamente em suas anotações. Porém, em um de seus registros, datado de 1906, sob o título A técnica da arte dramática, percebese que Stanislávski já discorre sobre "a necessidade de fazer, antes do espetáculo, não somente a toilette corporal, mas, principalmente, a toilette espiritual. Antes da criação, é preciso entrar em uma atmosfera espiritual que, única, torna possível o mistério criativo" (STANISLÁVSKI, 1999 apud VÁSSINA, 20 I3, p. 40). De acordo com a pesquisadora, esse trecho aponta para um dos pilares do processo de elaboração do Sistema, "a busca pelo elemento transformador para criar a "atmosfera espiritual" da arte do ator" (VÁSSINA, 2013, p. 40).

Por meio dessa indicação relativa ao desenvolvimento espiritual no palco, a historiadora russa alerta que se trata de um dos conceitos mais significativos da busca artística de Stanislávski. Outra anotação sobre essa temática é evidenciada em uma carta direcionada para a editora de seus livros. Nesse trecho Stanislávski apresenta um importante conceito sobre o processo de criação:

O Estado criador, assim como uma cidade litorânea, está bem na fronteira do infinito oceano do subconsciente. A cada momento, a criação pode mergulhar neste mar e, depois, de novo, voltar à Elevada Consciência Criativa.

Resumo do sistema: Subconsciente por meio do consciente. [...] A meu ver, o maior perigo para o livro está em "a criação da vida do espírito humano" (sobre o espírito não se pode falar). Outro perigo está em subconsciente, irradiação, absorção da irradiação, na palavra alma. Será que por causa disso podem proibir ○ livro? (STANISLÁVSKI, 1999 apud VÁSSINA, 2013, p. 40)

Nessa passagem, Stanislávski, revela duas questões significativas. A primeira, ao falar de subconsciente, provavelmente está se referindo ao fluxo do inconsciente, pois argumenta que é por meio do 
consciente que o ator atinge o subconsciente. A segunda é que Stanislávski viveu todo processo de transição de uma Rússia aristocrata e rural para a implementação do Estado Soviético, por isso coloca a observação que não se poderia falar sobre espírito. Esse dado é relevante, pois alguns temas que antes eram aceitos, tornaram-se questões idealistas que deveriam ser combatidas pelos bolcheviques.

Ao falar sobre desenvolvimento do espírito, o encenador poderia estar defendendo um conceito não materialista e bastante filosófico, que poderia resvalar em noções de desenvolvimento de psicologia do inconsciente, por exemplo. Assim, essa temática certamente seria perseguida pela censura soviética, uma vez que tudo que não fosse relacionado às questões materiais poderia estar contrário aos interesses do proletariado, tornando-se pensamentos burgueses.

De acordo com a pesquisadora, essa condição pode ter colaborado para a alteração da compreensão da pesquisa do renomado diretor e sugere ainda, a importância de se reconstruir algumas lacunas do processo de formação do sistema. Para Vássina (20l3), é nítido que Stanislávski dava extrema importância para o inconsciente no trabalho de criação do ator, sendo que é evidente que esse conceito aponta para íntima ligação com a natureza humana.

Vássina (20/3) reforça que a relação da teoria stanislavskiana com o yoga também sofreu interferências do pensamento do regime político. Conforme relatos apresentados pelo professor de interpretação teatral russo Tcherkásski (2019), em seu livro Stanislávski e o Yoga, existem diversas evidências e relatos que indicam a utilização do yoga no processo de aprimoramento do ator. Sabe-se que o primeiro contato do encenador com a antiga ciência espiritual foi em 1911, conforme indica o relato abaixo:

[...] durante as férias no sul da França, Nikolai Demídov, tutor do filho de Stanislávski e estudante de medicina tibetana, notou que muitas ideias sobre o sistema coincidiam com ensinamentos de yoga e recomendou que Stanislávski lesse os livros Hhatha yoga e Raja yoga (mais tarde, em 1917, Stanislávski vai ler o livro Concentração - uma aproximação à meditação, de Ernest Wood). A partir daí, a prática dos exercícios de yoga e, inclusive, alguns termos técnicos, como irradiação, concentração, círculo, pranayama, supraconsciência etc., começam a ser frequentemente aplicados nos ensaios de Stanislávski. [...] uma cultura inteira, que, além de tudo, se dirige ao infinito aprimoramento do homem que se dedica à arte, à ampliação de sua experiência espiritual e emocional, ao conhecimento do outro como a si mesmo (STANISLÁVSKI, 1999 apud VÁSSINA, 20I3, p. 43). 
De acordo com Tcherkásski (2019), além de ter adquirido o livro Hhatha yoga, ou a filosofia iogue do bemestar fisico, Stanislávski pode ter tido contato com as ideias de filósofos hindus, uma vez que o interesse pelo Oriente permeava a arte na transição do século XIX para $\circ \mathrm{XX}$. Em anotações percebe-se que Stanislávski propôs uma experiência de yoga para a resolução de questões de tensão desnecessária dos músculos nos treinamentos com os seus alunos do Primeiro Estúdio do Teatro de Arte de Moscou. Nessa mesma época, introduziu, na preparação dos atores, os conceitos de observador interno, objeto de atenção e círculo de atenção.

Uma das alunas de Stanislávski, Elena Poliakóva, ao relatar um trecho reconstruindo como havia sido o dia de trabalho no Estúdio, informa que "as improvisações se alternavam com a leitura de Hatha Yoga" (apud TCHERKÁSSKI, 2019, p. 3I). Sabe-se então que, nessa época o livro era leitura obrigatória entre os seus alunos. No trabalho desenvolvido, relacionado ao sentir-se a si mesmo como processo criativo da arte do ator, havia uma busca por atingir uma consciência tanto corporal quanto de alma. Tcherkásski (2019) relata que nos treinamentos muitos dos alunos indicavam a prioridade aos aspectos espirituais da arte do ator.

Relativo à temporada de treinamentos do período entre 1919 e 1920, há uma quantidade expressiva de anotações nos cadernos de Stanislávski sobre a utilização do yoga durante as aulas. Também fazia parte da preparação dos atores exercícios de ginástica sueca, treinamento vocal e liberação muscular. Sobre a utilização da libertação muscular, Stanislávski (1999 apud VÁSSINA, 20 I3,p. 38) esclarece:

Há dois momentos para a liberação muscular: a) a liberação (retroalimentação) do prana e b) sua transmissão. [...] Em primeiro lugar essa energia deve manter $\circ$ centro de gravidade do corpo em qualquer pose; em segundo, para agir não apenas como corpo, músculos, olhos ouvidos, com todos os cinco sentidos, mas também com a alma.

Evidentemente, coloca uma observação para seus seguidores de que todo o exercício físico deveria ser motivado, a princípio, ou justificado, por uma ação psicológica interna. Sabe-se que o objetivo dos iogues, quando estão se desenvolvendo, é o aperfeiçoamento do ser humano. Já os propósitos de Stanislávski para o aperfeiçoamento do ator, ao introduzir as práticas do yoga, não necessariamente foi o aprimoramento espiritual dos seus atores. Apesar de que, de acordo com Valerii Galendêev, "Stanislávski, nos últimos anos de sua vida, mais e mais frequentemente voltava-se ao problema da espiritualidade da palavra, dos movimentos e do silêncio do ator" (GALENDÊEV, 1990 apud TCHERKÁSSKI, 2019, p. 5I) .

Outra evidência, sobre essa possível relação com o 
aprimoramento da espiritualidade do ator no processo de aplicação do Sistema, está diretamente relacionada com a questão da respiração. De acordo com o iogue Ramacharaca (1974 apud TCHERKÁSSKI, 2019, p. 46),

[...] a potência espiritual do ser humano, sua felicidade, autocontrole, clareza de pensamento, moralidade e mesmo o desenvolvimento espiritual podem ser fortemente expandidos por uma utilização consciente e prática da Ciência da Respiração.

Segundo Tcherkásski (2019, p. 46):

[...] o próprio Stanislávski dedica uma quantidade considerável de tempo à explanação básica sobre os princípios da respiração explicando a ligação entre uma respiração correta e a atenção, entre a respiração correta e a educação do ator.

Para o professor russo é possível estabelecer um comparativo entre os elementos fundamentais do Sistema e os princípios do yoga. Destacamos algumas das principais semelhanças:

Liberação muscular: Stanislávski considerava a liberação das tensões musculares $o$ primeiro passo a caminho da conquista do sentir-asi-mesmo criativo, e, ainda que ele mesmo não tenha praticado as asanas (posições do yoga) diretamente, dava bastante atenção à educação, do ator, de técnicas para o relaxamento físico, que é um dos princípios do yoga. [...]. Comunicação e irradiação de prana: um dos empréstimos mais importantes que Stanislávski fez do yoga foi a concepção de prana. A palavra sânscrita (traduzindo: vento, respiração, vida) denota, na filosofia do yoga, o princípio vital do ser humano, a alma. Os raios de energia vital (prana), de acordo com o yoga, submetem-se à vontade da mente $e$ é precisamente a irradiação de prana que se torna para Stanislávski, o meio de garantir a comunicação autêntica entre os atores - com o parceiro de cena, consigo mesmo, com um objetivo, com o espectador[...].

Atenção: Stanislávski emprestou do Raja Yoga os canais concretos para a intensificação da concentração da atenção e da capacidade de observação. Trata-se da atenção multifocal, trabalhada durante séculos pelo treinamento dos iogues, e dos procedimentos práticos para desenvolvimento da concentração quase para serem utilizados para o aperfeiçoamento da psicotécnica do ator. [...] Em seus exercícios sobre a disciplina da atenção, os iogues ensinam a superar toda a influência exterior que distrai [...].

Visão e imagens: Esse importante elemento do Sistema liga-se às técnicas meditativas do yoga. As percepções de Stanislávski acerca da necessidade das "imagens e visões interiores" sobre a criação do "filme de imagens" e sobre o significado dos “devaneios" artísticos estão inextricavelmente conectadas a outro elemento do sentir-a-si-mesmo criador: a imaginação, analisada no 
quarto capítulo de $\mathrm{O}$ trabalho do ator sobre si mesmo no processo criador da experiência do vivo [...].

Superconciente: Do Raja Yoga, Stanislávski extraiu a ideia conceitual da ligação entre o estado criativo e o inconsciente, como a fonte da intuição artística e do conhecimento transcendental. Essa ideia, importantíssima, perpassa todas as buscas de Stanislávski, a partir da metade dos anos 1910. [...] De acordo com os iogues, a vida inconsciente do ser humano é composta de duas partes: o subconsciente, que está em cada um, e o superconsciente, que supera $\circ$ indivíduo, uma espécie de consciência superior, pertencente à esfera do transcendental. Para Stanislávski, a arte toca precisamente o componente superior. Para ele, a arte faz despertar, e precisamente por isso é capaz de existir para além da cultura, dos séculos, das diferenças individuais. Todo o páthos emocional e, ousamos dizer, religioso de Stanislávski relativo "aos mistérios da natureza criadora da vida", todo o seu entendimento do teatro está intimamente relacionado à descoberta deste fenômeno maravilhoso da psique humana. [...]

"Eu sou": [...] Stanislávski, apoiando-se na autoridade de cientistas europeus, fala sobre o elemento mais importante que extraiu do yoga e sobre como este coincide com a experiência pessoal do ator: "Mais do que tudo, o superconsciente eleva alma do ser humano, por isso mesmo é ele o que deve ser mais caro e resguardado em nossa arte."

[...] Para o yoga, o superconsciente é o cerne de um estado de santidade, pelo qual o aspirante alcança, no final das contas, o oitavo e último degrau do yoga de Pantanjali, chamado samadhi. Como nota White, "o samadhi tem vários níveis, mas o estado mais elevado de meditação é alcançado quando o aspirante se entrega completamente ao objeto de meditação. Para o yoga, - objeto de meditação é Deus. Para Stanislávski, é o papel."

É precisamente para a transmissão desse estado transcendental de união com o papel que Stanislávski introduz conceito "eu sou". De certa forma, - "eu sou" de Stanislávski é um sinônimo do estado criativo do ator em processo genuíno da experiência do vivo (TCHERKÁSSKI, 2019, p. 78108)

Em relação à prática do yoga no Sistema de Stanislávski, Tcherkásski (2019) sugere que este é um trecho de uma questão mais ampla que merece investigação, uma vez que as técnicas psicofísicas orientais tiveram grande influência no treinamento dos atores do século $X X$. Entre os autores que tem uma relação com essa questão cita nomes como Jerzy Grotowski, Peter Brook e Eugenio Barba, entre outros.

Como já foi dito anteriormente, Brook sofreu influência direta da doutrina mística de Gurdjief, e nesse sentido, Tcherkásski (2019, p. 27) aponta que o mestre greco- 
armênio certamente extraiu seus princípios "livremente elementos do islã, do yoga e mesmo da numerologia e teosofia, apoiando-se no bramanismo e no budismo nas interpretações de gente como Helena Blavatsky (I83I189I)".

Outra questão bastante relevante para essa pesquisa é evidenciada por Vássina (20I5) como o "novo método" de Stanislávski, descrito de acordo com seu último texto, intitulado: Abordagem à criação do papel, descoberta de si mesmo no papel e o papel em si mesmo. A autora inicia seus relatos sobre o encenador alertando que, ao longo de sua trajetória, Stanislávski se contradisse diversas vezes, alterando como que em um processo dialético o desenvolvimento de seu método. Estava disposto a abrir mão de sua experiência anterior e se lançar ao desconhecido, à procura de novas possibilidades de desenvolvimento na arte da interpretação teatral.

Stanisláviski percebe que, para auxiliá-lo na verificação de seu "novo método" de ensaios, era preciso que atores talentosos estivessem livres de vícios teatrais e, também dispostos a auxiliá-lo na sua pesquisa em formação. Nesse contexto, o diretor não deveria ter uma ação tão incisiva sobre o ator, pois visava aprimorar o desenvolvimento de sua personalidade artística. E, dessa maneira, o intérprete deveria ter independência "na elaboração de études ${ }^{6}$ e improvisações livres a partir da descoberta de si mesmo no papel e do papel em si mesmo" (VÁSSINA, 2015, p. 124). Com essa observação é possível identificar uma aproximação bastante significativa entre os processos de criação de Stanislávski e Brook, tema que será abordado no capítulo 2.

Desse modo, conforme indica Vássina (20I5), o objetivo da busca artística de Stanislávski era atingir a inspiração divina e inconsciente, e o percurso para acessar esse campo secreto e sagrado seriam criações físicas e verbais indicadas no Sistema.

Stanislávski explica que os atores que se entregam ao texto dramático, passam a acreditar no autor cegamente e, em vez de se inspirar em si mesmos, começam a seguir aquilo que fornece a peça e acabam imitando a obra alheia, e não criando a partir de si próprios. Stanislávski acredita fielmente que o único caminho para o desenvolvimento da arte do ator é "a partir de si próprio”, caso contrário, começa a atuação baseada em clichês e em procedimentos repetitivos (VÁSSINA, 20I5, p. I24).

No primeiro momento do conhecimento da peça, o autor com todo o poder de sua autoridade fecha - caminho livre do artista, aquele caminho que o leva para os fundos segredos de sua própria alma onde se guarda o mais valoroso para a criação: o vivo e vibrante material psicológico do

${ }^{6}$ De acordo com Vássina (20I5), Stanislávski sempre utilizou o termo étude para definir as improvisações, tanto em seu processo pedagógico, quanto no processo de criação do espetáculo. 
artista. Preserve a ligação espontânea com ele. Desta maneira, tudo indica que $o$ artista precisa sentir a vida da peça e do papel ainda antes de seu conhecimento (STANISLÁVSKI, 1994 apud VÁSSINA, 2015, p. 125).

É importante salientar que, quando Stanislávski começou a experimentar o seu "novo método", não desconsiderou a questão da memória afetiva. Contudo, esse conceito, nessa fase de sua pesquisa, passou a ser desenvolvido juntamente com as ações físicas, o que, segundo a pesquisadora russa, resultou em uma síntese, ou seja, uma fusão dos elementos básicos do Sistema, já que as emoções nesse contexto poderiam ser provocadas com base nas ações que, por sua vez, deveriam também se conectar com a memória afetiva do intérprete (VÁSSINA, 20I5).

Essa possível fusão dos elementos pode indicar que, possivelmente, Grotowski tinha mais conhecimento sobre os estudos de Stanislávski, especialmente sobre esse último momento determinado como "novo método", conforme será possível averiguar adiante. Ao apresentar Grotowski, em seu livro Ponto de Mudança, Brook (1994) afirma que ninguém depois de Stanislávski, investigou a essência da interpretação, suas características e o significado de sua natureza como Grotowski.

Em 2000, em outro texto para o colóquio Os Pensadores do ensinamento intitulado Qualidade e artesanato, o encenador estudado estabelece algumas semelhanças entre os diretores russo e polonês. Afirma que Grotowski havia the revelado que tinha um desejo profundo: "Antes do fim da minha vida, eu gostaria de passar, por um momento, para além das formas, das formas da vida, e fazer a experiência daquilo que está por trás" (BROOK, 20I I, p. 67).

Para atingir o objetivo pretendido, de início, se apoiou no método stanislavskiano, informando que na arte: "Stanislávski é meu pai" (BROOK, 20II, p. 67). Para Brook, isso indicava que Grotowski saberia que Stanislávski havia desenvolvido uma pesquisa semelhante à dele, e tinha pretensões de estabelecer uma metodologia à altura da sua fonte. Em seu discurso, assegura que Stanislávski não tolerava a mediocridade no desenvolvimento dos seus trabalhos teatrais, mas "descobriu que o ator dotado de um dom, talvez vindo do céu, poderia por intuição, produzir alguma coisa de qualidade" (BROOK, 20I I, p. 67).

Grotowski tinha certeza de que deveria existir alguma ciência entre a grande aspiração à qualidade e à realização de um bom trabalho. Esta foi, a partir de então, a sua maior dedicação no campo da pesquisa teatral. Desse modo, quando descobriu as ações emocionais em seguida as físicas, buscava sempre a origem científica de suas investigações. 
Se Stanislávski queria obter a qualidade dentro do "naturalismo" do comportamento cotidiano, Grotowski buscava alcançar alguma coisa mais oculta. Enquanto Stanislávski queria trabalhar o impulso concreto, como aquele de querer se assentar sobre uma cadeira, por exemplo, Grotowsk queria encontrar a impulsão de um gesto absolutamente desconhecido, um gesto que não poderíamos encontrar em nenhum outro lugar da vida cotidiana, nem na linguagem das tradições orientais ou europeias. Grotowski queria alcançar o impulso puro. Ora, um impulso, ele sabia, não é visível; ele deve ser portado por alguma coisa, e este portador, este veículo, é o corpo humano (BROOK, 201।, p. 67-68).

Jerzy Grotowski, é considerado, por muitos, como místico, e seu teatro tem reputação de ser sagrado. Segundo Peter Brook, o teatro de Grotowski “é sagrado, porque a sua função é sagrada” (BROOK, 2008, p. 84) Tinha um propósito sagrado, pois justamente identificava que o teatro não deveria ser o seu propósito, mas "um veículo, um meio de análise e exploração pessoal, uma hipótese de salvação [em que] o ator trabalha a sua própria pessoa” (BROOK, 2008, p. 83). Sua pesquisa propôs ultrapassar a comunicação racional e, conforme dito anteriormente, utilizou muitos dos ensinamentos de Stanislávski como elemento de partida para o desenvolvimento de sua própria metodologia.
Quando tentou seguir os passos de Stanislávski e aplicar as técnicas do yoga na criação teatral, Grotowski observou que essa aplicação começou a contrariar as possibilidades da expressão teatral. Em seu texto, Em busca de um Teatro Pobre, escreve:

[...] começamos fazendo yoga diretamente, visando a uma concentração absoluta. É verdade, perguntamos, que o yoga confere ao ator o poder da concentração? Observamos que, apesar de todas as nossas esperanças, acontecia exatamente o contrário. Havia uma certa concentração, mas era introvertida. Esta concentração destrói a expressão, trata-se de um sono interno, um equilíbrio inexpressivo, um repouso absoluto que elimina todas as ações. Isto deveria ser óbvio, porque o objetivo da yoga é parar três processos: o pensamento,

a respiração e a ejaculação. Isso significa que todos os processos da vida estão interrompidos, e encontrase a plenitude e a realização numa morte consciente, numa autonomia fechada em nossa própria essência (GROTOWSKI, 1987, p. 207).

Contudo, apesar da sua observação anterior sobre a aplicação diretamente no treinamento do ator não parecer adequada, o diretor polonês não perdeu - interesse pela técnica, independentemente das possibilidades de sua aplicação no teatro. $\bigcirc$ fascínio pelo yoga precedeu a sua chegada ao teatro. Tcherkásski (2019) expõe que Grotowski se propôs a buscar 
diferentes tipos de contato nos exercícios de yoga, de modo a alterar a ordem de reações no ser humano, ou seja, transferir a ênfase da utilização do yoga com o objetivo de uma concentração introvertida, para a comunicação direta com o companheiro de cena.

Dessa forma, o ator é seu próprio instrumento de investigação e para conseguir utilizá-lo, é fundamental que conheça todos os aspectos de si: corpo, mente e espírito. Era fundamental que houvesse muito rigor no trabalho, e que este fosse ancorado por um amplo processo de autoconhecimento, tanto pessoal, quanto artístico. Sendo assim, conforme indica Brook (2008, p. 83), o "ator não hesita em mostrar-se tal qual é, pois sabe o segredo da personagem exige de si uma abertura total, revelando os seus próprios segredos".

Em Avec Grotowski, Brook (20II) revela que o encenador polonês se ocupa de um laboratório e, como tal, não precisa de espectadores, só ocasionalmente, em número reduzido e de acordo com o desenvolvimento da pesquisa. Cria, então, uma espécie de culto, tendo em vista o seu desejo por alcançar o sagrado. Nesse sentido, o teatro é um meio de análise pessoal, que se dispõe a uma possibilidade de salvação. Transforma, assim, o fazer teatral quase em um ritual de sacrifício.

Os atores grotowskianos oferecem sua representação como uma cerimônia àqueles que desejavam assisti-los. "O ator invoca, revela aquilo que está adormecido no fundo de cada homem e que mascara a vida cotidiana" (BROOK, 2009, p. 19). O objetivo final do encenador polonês era promover uma pesquisa acerca do comportamento e da vida humana, transformando o ator em um ser humano essencial. $\bigcirc$ intérprete é o instrumento de sua arte, e seu compromisso é com a forma dessa arte.

Grotowski, ao reconhecer as influências de Stanislavski em suas pesquisas, propôs uma técnica de "integração de todos os poderes corporais e psíquicos do ator, os quais emergem do mais íntimo do seu ser e do seu instinto, explodindo numa espécie de transiluminação" (GROTOWSKI, 1992, p. 14). Desenvolveu seu próprio método de interpretação que buscava, por meio de um exaustivo trabalho de corpo e de voz, atingir o despojamento de todas as questões mais íntimas do ator. Pretendeu retirar a resistência do organismo do ator ao processo psíquico e eliminou o lapso de tempo entre o impulso interior e reação exterior, para que tanto o impulso como a ação fossem concomitantes. A essa forma de trabalhar deu o nome de Via Negativa.

Essa metodologia de trabalho se manteve durante todo o seu percurso como pesquisador teatral. Tratava-se, além do que foi exposto anteriormente, de um processo de eliminação. $O$ objetivo era que os atores não se concentrassem no processo intelectual da composição do papel, mas na sua composição, na 
construção da forma e na instituição de símbolos. Em um primeiro momento eliminou a maquiagem, a cenografia e a proposição dos trajes de cena, além dos efeitos de iluminação e sonoros, para atingir o essencial na realização da arte teatral. Assim, só permaneceram em cena o ator e os espectadores.

Em outro momento, estabeleceu um trabalho diário com seus atores, cujo objetivo era a eliminação de qualquer impedimento aos impulsos corporais orgânicos, ou seja, atingir o impulso puro. Aboliu, na sequência, o contato do ator com os espectadores. No texto, Da companhia teatral à arte como veículo, Grotowski (apud FLASZEN; POLASTRELLI, 2007, p. 232) fala que "no espetáculo, a sede da montagem está no espectador; na arte como veículo a sede da montagem está nos atuantes, nos artistas que agem".

Com esse novo trabalho, Grotowski advertiu que o processo de investigação teatral correspondia a um velho interesse seu; que de forma consciente e deliberada, pretendia passar por cima das forças vitais para atingir a "verticalidade - fenômeno de ordem energética: energia pesadas mas orgânicas ligadas às forças da vida, aos instintos, à sensualidade e outras energias mais sutis" (apud FLASZEN; POLASTRELLI, 2007, p. 23I).

Tratava-se do ponto de contato da sua exploração cênica no caminho do aprimoramento da espiritualidade.
Propôs, nesse caminho, que a sua pesquisa seguisse em direção ao ritual, mas não o ritual religioso. Para o polonês o ritual era objetivo, e queria dizer que "os elementos da ação são instrumentos de trabalho sobre o corpo, o coração e a cabeça dos atuantes." (FLASZEN; POLASTRELLI, 2007, p. 232). Portanto, o ritual era ação, e seu caminho levava determinadas pessoas - seus atores em exercício -, na direção da sua essência. De acordo com Slowiak (2013, p. 127), essência em Grotowski é "aquilo que não provém do exterior, aquilo que não se aprende".

Grotowski pretendia chegar a um "ator santo”, capaz de se sacrificar para revelar a parte mais íntima de si, que seria capaz de eliminar os obstáculos que se apresentavam para mostrar aquilo que é invisível.

A diferença entre o 'ator cortesão' e o 'ator santo' é [...] auto sacrifício. O fato essencial no segundo caso é a possibilidade de eliminar qualquer elemento perturbador, a fim de poder superar todo o limite convencional. No primeiro caso, trata-se do problema da existência do corpo: no outro, antes, da sua não-existência. A técnica do "ator santo. é uma técnica indutiva [...] uma técnica de eliminação, enquanto a do "ator cortesão. é uma técnica dedutiva [...] um acúmulo de habilidades (GROTOWSKI, 1987, p. 30).

"Santo" no contexto proposto não deve ser compreendido no sentido religioso. Trata-se de uma 
metáfora que exprime "uma pessoa que, através da sua arte, transcende os limites e realiza um ato de auto sacrifício" (GROTOWSKI, 1987, p. 38). É um ser humano capaz de solucionar os próprios problemas do corpo, ser consciente dele, e ainda se libertar de todas as suas resistências. Ao trabalhar estas questões,

[...] o ator que nesse processo especial de disciplina, de auto sacrifício, auto penetração, e amoldamento, não tem medo de ir além dos limites aceitáveis, atinge uma espécie de harmonia interior e de paz de espírito (GROTOWSKI, 1987, p. 39).

Dessa forma, na sua pesquisa em direção ao sagrado, Grotowski se relaciona com uma questão que também será observada adiante na proposta de Gurdjieff: a busca pela essência (aquilo que pertence ao ser humano) e o afastamento da personalidade (aquilo que não pertence ao ser humano, implantado pelos padrões sociais). Brook (20II) assegura que Grotowski não teve um contato direto com o trabalho de Gurdjieff, porém, pode acessar seus conhecimentos por meio das ideias deixadas na literatura, pelo próprio mestre ou pelos textos de seus discípulos.

No discurso de abertura da conferência Tender para a Essência, Brook (20II, p. 74) afirma que todos os aspectos da vida interessavam a Grotowski:

[...] seu conhecimento da ciência, contemporânea e tradicional, das tradições psicológicas, religiosas ou espirituais. E ao longo de anos, cada vez que nós nos encontrávamos, nossa conversa nos levava a uma figura fora do comum, aquela de Gurdjieff.

Evidencia, também, que o encenador polonês sabia que Gurdjieff não tratava somente da arte da representação, mas sobre os domínios da vida.

Ao ser questionado se Grotowski haveria utilizado os ensinamentos de Gurdjieff para os seus próprios fins, Brook é categórico. Ressalta que uma das preocupações de Grotowski era a pureza da ação, logo, em seu caminho jamais imitaria quaisquer formas que fossem.

Não, o trabalho de Grotowski era exclusivamente seu. Muito preciso, muito original, impossível de se imitar. $E$, no entanto, Gurdjieff representava também para ele um fogo, um vulcão. E se nós estamos aqui hoje dentro do mundo de Grotowski, nós precisamos evitar um mal-entendido muito tentador: isto que Gurdjieff trouxe à compreensão contemporânea não serve para fazer de nós melhores atores, melhores músicos, nem pessoas melhores. Isso se situa em um plano muito diferente com um objetivo muito diferente. Gurdjieff trouxe para o século $X X$ elementos vivos de um ensinamento que ele jamais pretendeu ter inventado. Ele os elaborou longe, no passado, e conseguiu aplicá-los em vários aspectos da nossa vida contemporânea (BROOK, 20II, p. 75).

Finalmente, é possível concordar com a observação de Tcherkásski (2019) sobre o significado de teatro para 
Grotowski. O pesquisador salienta que era apenas um meio para conquistar um objetivo, e não o objetivo em si. Schechner (1997 apud TCHERKÁSSKI, 2019, p. 64.) declara, em relação à colocação anterior, que "A supertarefa de Grotowski era espiritual, e estava na busca e na educação da alma de cada um dos intérpretes".

\section{I.3 QUEM FOI GEORGE IVANOVITCH GURDJIEFF - MENTOR ESPIRITUAL DE PETER BROOK}

Katheleen Speeth (1976), psicóloga e professora norteamericana, suspeita que a data de nascimento de George Ivanovitch Gurdjieff seja próxima a 1872, ainda que em seu passaporte conste o dia 28 de novembro de 1877 . Ele nasceu em Alexandrópolis, na região do Cáucaso, atual Rússia, filho de pai grego e mãe armênia. Desde cedo foi induzido a interrogar-se sobre si mesmo: tornou-se uma figura enigmática e bastante influente, tanto em relação aos ensinamentos religiosos quanto psicológicos na Europa e no Oriente.

Enquanto ainda era criança mudou com sua família para Kars, uma cidade próxima a sua cidade natal. Ali teve oportunidade de estudar com seu próprio pai e com o decano da catedral militar russa. Dois homens que, segundo Gurdjieff, foram os principais responsáveis por despertar nele a necessidade de compreensão sobre o processo de vida no planeta e, em particular, por buscar compreender o objetivo da vida humana. Este era $\circ$ momento de levantar questões como: para que se vive? E o que há no fim de tudo, ou seja, na morte?

Havia se preparado para ser médico ou sacerdote. Estudou, particularmente todo o material disponível nas bibliotecas sobre neurofisiologia e psicologia. Contudo não encontrou, nos estudos, as respostas que procurava. Estava convencido de que, em algum lugar e em alguma época, existiram escolas ou comunidades que possuíam o conhecimento verdadeiro. Começou a estabelecer contato com algumas sociedades secretas e com diferentes grupos religiosos, para ter acesso ao que ficou conhecido como santuário dos santuários base para maioria das organizações herméticas.

Desse modo, "aprendeu muito sobre o simbolismo secular da liturgia, sobre as técnicas de respiração rítmica e prece mental, que ainda faziam parte dos deveres religiosos do monge ortodoxo" (SPEETH, 1976, p. 14). Porém ainda não estava satisfeito com a evolução de seu entendimento sobre as perguntas básicas que havia feito para si quando jovem. Decidiu, então, iniciar uma peregrinação em busca de mais conhecimento. Percorreu, por vinte anos, a Ásia Central e o Oriente Médio para encontrar as fontes vivas de um conhecimento oculto - anos estes que foram extremamente importantes para a formação de 


\section{seu pensamento.}

Organizou um grupo, com aproximadamente vinte homens e uma mulher, que estava empenhado em buscar o conhecimento oculto, se auto intitularam de Os buscadores da verdade. Juntos percorreram e examinaram ruínas de civilizações antigas no Egito, em Creta, na Suméria, na Assíria e, inclusive, em Jerusalém. Também caminharam pelos vales do Norte da Sibéria à procura de raízes xamanísticas ou de ramificações do conhecimento desejado. Seus principais focos de pesquisa eram a transformação da energia no corpo humano, os diferentes estados de consciência humana e a utilização da música, da arte, da postura e do gesto para modificar a consciência.

\section{Descobriram evidências que,}

[...] em certas civilizações antigas, existiram métodos objetivos para composição de melodias que produziam reações emocionais idênticas em todos os ouvintes; edifícios de tal modo construídos que o simples ato de penetrar neles produzia estados de consciência alterados, e danças de tal modo coreografadas que o estado interior do dançarino era determinado com exatidão. Gurdjieff coletou danças. Nelas, ele tinha esperanças de encontrar chaves que conduzissem à explicação do mistério da mente e do corpo humano (SPEETH, 1976, p. I516).
Para Speeth (1976), a influência mais intensa sobre o desenvolvimento de Gurdjieff provavelmente era proveniente do seu contato com o sufismo, com nuances dos rituais islâmicos. Há evidências que indicam que o símbolo central do "trabalho" de Gurdjieff - o eneagrama - tenha origem sufi, o que indica a importância desta doutrina (dervixe bokhariano7) no sistema que foi desenvolvido posteriormente. Em Moscou, na primavera de 1915, o místico encontrou, pela primeira vez, com Peter Ouspensky, que se tornou um de seus principais discípulos, e o responsável por transmitir seus ensinamentos para o Ocidente por meio dos registros das suas conferências em Moscou.

De acordo com Ouspensky (2016), seu mestre tinha uma personalidade humana muito forte, acompanhada de uma espiritualidade muito elevada, tanto moral como metafisicamente. Dizia que suas condutas eram regidas pelas mais altas intenções morais, que era um verdadeiro mestre no domínio da inteligência e do espírito. Apresentava suas ideias de maneira que se refletiam como verdade. Lançava um novo olhar sobre questões fundamentais acerca do ser humano e sua relação com o universo; sobre os diferentes níveis de consciência; a respeito da condição de mortalidade e imortalidade e da possibilidade de auto realização.

${ }_{7}$ Dervixe é um praticante que segue o islamismo sufista, conhecido por sua extrema pobreza e austeridade. Desse modo, são semelhantes às ordens mendicantes dos monges cristãos e dos sadhus hindus e budistas. 
Em 1917, com a guerra instaurada pela Revolução Bolchevique, a Rússia se tornou um local inseguro para o desenvolvimento das pesquisas do grupo. Gurdjieff e seus discípulos, dentre eles Thomas Hartmann, Peter Ouspensky e sua esposa, fugiram de Moscou em uma viagem tortuosa, a pé, pelas montanhas. A princípio, seu destino era Essentuki, no Cáucaso, posteriormente, quando a vida naquele local se tornou bastante difícil, rumaram para Tíflis. Foi nesta cidade que outros discípulos se juntaram ao mestre, inclusive Alexandre e Jeanne de Salzmann, vindos de Paris.

Após uma longa peregrinação por países da Europa e do Oriente Médio, o grupo liderado por Gurdjieff se estabeleceu nos arredores de Paris, no Castelo de Prieuré, e fundaram o Instituto para o Desenvolvimento Harmonioso do Homem. Nos primeiros anos eram raros os franceses que se reuniram ao grupo, porém Alexandre de Salzamann - pintor e decorador de teatro -, e sua esposa se tornaram responsáveis por auxiliá-lo a reverter a situação.

A única manifestação pública do espiritualizado mestre e de seus alunos, durante esse período, foi uma demonstração de danças sagradas e de "movimentos", os quais foram apresentados no Théâtre des ChampsElysées, em outubro de 1923. Esses exercícios foram exibidos, ao mesmo tempo, tanto como uma restituição de danças e de cerimônias sagradas, quanto método de educação. Entretanto, os parisienses não estavam preparados para ver nas danças, mesmo sagradas, outra coisa além de um simples espetáculo. Em 1949, quando Gurdjieff morreu em Paris, ainda era desconhecido da maioria do público, mas alguns de seus seguidores, como Madame Jeanne de Salzmann e Jane Heap entre outros, se encarregaram de transmitir suas ideias.

Elas permitiram que as pessoas entrassem em contato com as suas técnicas e abrissem seus olhos para o caos interior no qual viviam. Suscitavam questões como: por que estamos aqui? O que queremos? A que forças nós obedecemos? E, principalmente, se compreendemos - que somos. As experiências proporcionadas, a partir desse contato, eram impiedosas para alguns e impossíveis de serem suportadas para outros.

De acordo com Gurdjieff (apud OUSPENSKY, 2016), os homens são como máquinas que funcionam automaticamente em estado inconsciente, ou seja, estão adormecidos. Todas as suas realizações, ações, palavras, pensamentos, sentimentos, convicções, opiniões e hábitos, são resultado de influências e impressões externas. A maioria das pessoas vive e morre em um estado de "sono", sem questionar o sentido da vida. Então, o objetivo do seu trabalho era acordar cada indivíduo, para que ele tome consciência da divisão dos centros de desenvolvimento. Com essa conscientização, seria possível perceber que cada 
pessoa é composta por múltiplos eus, que se sustentam por meio de diversos tipos de agregados ${ }^{8}$ psíquicos tais como: arquétipos, ancestralidade, vidas passadas e relações telepáticas.

Em seguida o desenvolvimento caminha para a distinção de quais seriam as principais influências compulsivas para se liberar delas. Nesse sentido, o primeiro movimento é descobrir qual "centro de energia" é predominante no seu comportamento: intelectual, emocional ou instintivo-motor. Para ele, os "centros de energia" estariam desconectados uns dos outros. Mas, seguindo suas descobertas, existia a possibilidade de alcançar uma harmonia entre mente, corpo e sentimento, com várias técnicas para tornar os centros 'despertos'. Geralmente, para isso acontecer, era necessário aplicar alguns choques de consciência.

Com este intuito desenvolveu um complexo sistema de pensamento, incluindo uma abrangente cosmologia e metafísica e uma teoria sobre o processo de evolução do homem. Sua filosofia estava embasada em proporcionar um autoconhecimento profundo, processo de lembrança de si mesmo - o primeiro choque de consciência. $O$ homem 'desperto' - aquele que tem consciência de si - é bastante raro, de acordo

${ }^{8}$ Os agregados são os aspectos que constituem os seres capazes de sentir sensações e sentimentos de forma consciente. Para a tradição Theravada, forma mais antiga do budismo, o sofrimento tem origem no apego aos agregados, sendo o desapego aos mesmos a chave para a libertação do sofrimento. com os ensinamentos transmitidos pelo mestre. $O$ objetivo central de Gurdjieff era a autotransformação por meio da consciência, do autoconhecimento e da auto-observação - os principais passos para o processo de despertar.

De modo a atingir tal objetivo, ou seja, alcançar os níveis superiores do ser e ter ciência de si, é fundamental estabelecer um equilíbrio das energias (atitudes e pensamentos) positivas e negativas, próprio da natureza humana - conhecido como o segundo choque de consciência. Em seguida, é importante descobrir qual é o centro de energia que está negligenciado para poder, desse modo, estabelecer qual dos nove pontos do eneagrama (figura I) está relacionado.

No entanto, para Gurdjieff (apud SPEETH, 1976), os nove pontos do eneagrama não se constituem em uma tipologia própria, trata-se de uma classificação sistemática de nove tipos de personalidade baseados na lógica de traços e características cognitivas, identificadas pelo mestre. Para ele, cada ser humano nasce com uma essência que não é uma tábula rasa - embora existam espaços em branco -, nos quais as experiências de vida deixam suas marcas. Trata-se de uma identidade própria e real, com tendências e predisposições. Já a personalidade seria uma máscara da verdadeira essência do ser humano.

A personalidade atua de maneira a perpetuar a 
Figura $0 \mathrm{I}$ - Eneagrama de personalidade de Gurdjieff.

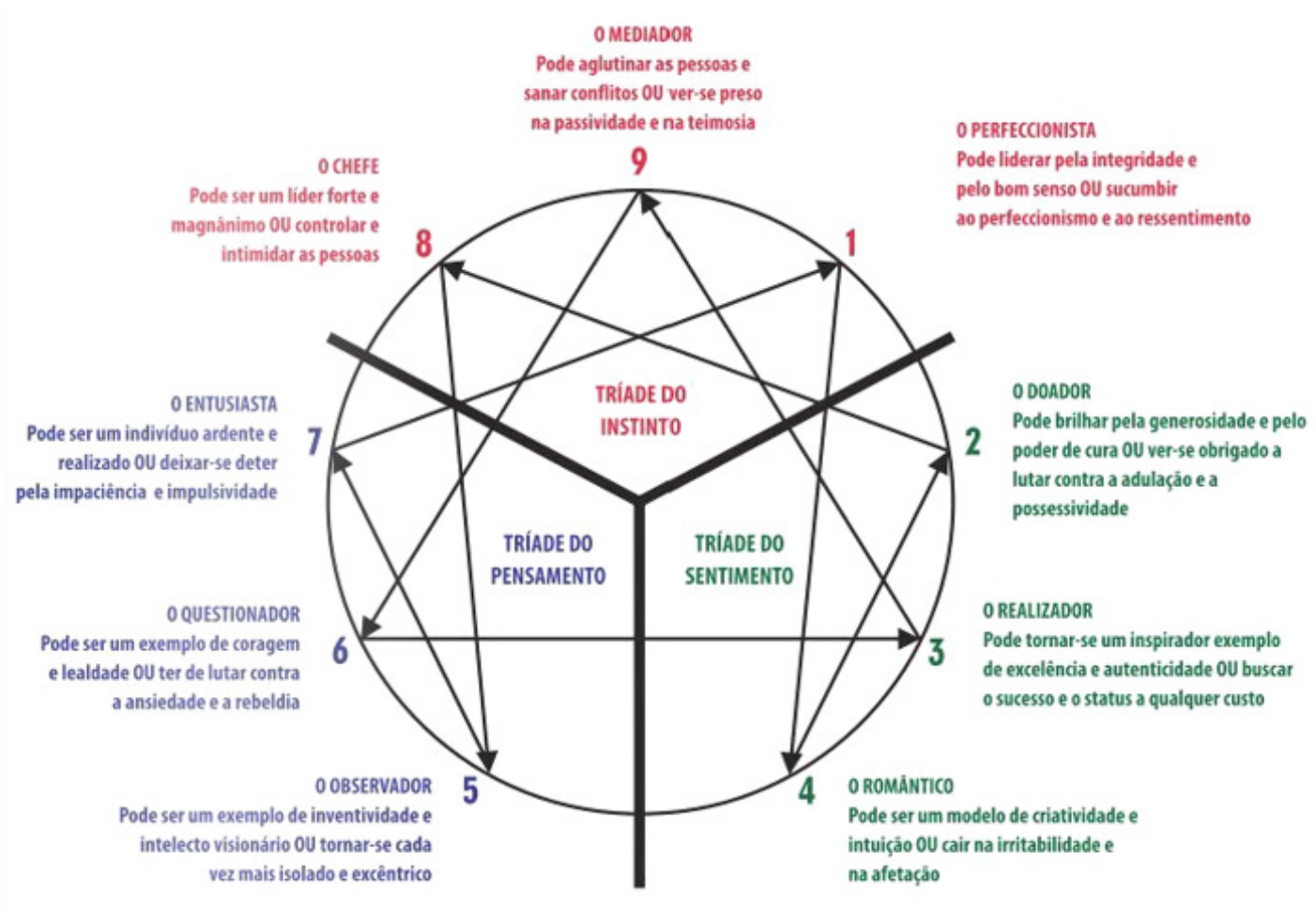

Fonte:Werkema (2007).

inconsciência do ser humano com base em "um ponto cego", uma vez que direcionou, para esta situação, energia de forma desequilibrada. A personalidade e a inconsciência se estabelecem, portanto, um círculo vicioso em que o condicionamento da personalidade acarreta em uma interferência específica no organismo biológico, ressaltando o ponto de fixação do eneagrama. Essa interferência no organismo provoca, então, uma perda de contato com sua essência, sugerindo que se estabeleça o ciclo de perpetuação da personalidade conformada.

Em algum momento do desenvolvimento, um dos nove pontos da circunferência é estabelecido e, a partir deste ponto, se constrói a personalidade. Por sua vez, a personalidade é algo que é constituído por fatores 
externos e, por esse motivo, poderia ser alterada por intermédio da mudança de padrões de comportamento. Para que se sobressaia a essência, até que ela alcance a maturidade, sendo possível emanar aquilo que é real e verdadeiro no íntimo do indivíduo, é preciso que seja realizado o trabalho sobre si mesmo.

Contudo não se pretende destruir completamente a personalidade do ser humano, pois para seu sucesso é necessário que se encontre o equilíbrio entre uma essência e uma personalidade saudáveis, pois sem desenvolvimento da personalidade não há o desejo por atingir estados de consciência mais elevados. Com o objetivo de estabelecer o equilíbrio das funções psíquicas e alcançar a verdade, existem três caminhos tradicionais propostos pelas distintas religiões que foram classificados por Gurdjieff (apud SPEETH, 1976, p. 77-79), a saber:

- O caminho do faquir - diretamente relacionado com o centro instintivo-motor, ou seja, sua busca não exige muito conhecimento e está diretamente relacionado com o desenvolvimento do corpo físico, de modo a suportar posturas e exercícios desafiadores, fortalecendo assim, a vontade humana.

- O caminho do monge - tem como foco o centro emocional. Trata-se do percurso da devoção, do sacrifício religioso e da fé, em que todos os desejos são contidos em amor a Deus. Desse modo transcende-se as emoções e alcança-se o autodomínio.

- O caminho do iogue - se conecta com o centro intelectual. É o caminho do conhecimento mas, apesar de ser possível que o iogue alcance a compreensão total do conhecimento, se os demais centros não estiverem no mesmo patamar, seus estudos permanecem impotentes e estéreis. Para atingir a unidade serão precisos novos estudos e esforços na sequência.

Há ainda um outro caminho que foi estabelecido a partir do desenvolvimento de suas pesquisas. Trata-se da harmonização entre as funções psíquicas por meio do desenvolvimento gradual dos centros, ou melhor, é o trabalho realizado simultaneamente, nos três centros de modo a permitir que se atinja o equilíbrio entre eles ao mesmo tempo. Ao contrário dos caminhos religiosos tradicionais, o quarto caminho não tem instituições permanentes. São grupos de trabalho que se estabelecem para o aprimoramento e desenvolvimento pessoal. Muitos deles se intitulam "grupos de quarto caminho" ou "grupos de trabalho sobre si".

Nestes grupos, o "processo de despertar" ou o "trabalho" - nome dado ao ensinamento de Gurdjieff - é o conhecimento real de si mesmo, que deve ocorrer todos os dias em seu próprio ambiente ou em grupo. O mais importante são os "movimentos" ou danças sagradas - um conjunto de danças rítmicas ou posturas físicas, com exercícios físicos de respiração 
e meditações, projetadas para liberar as energias do corpo. Elas envolvem algumas posturas complexas e movimentos assimétricos, cada um dos quais tem como objetivo provocar certo estado ou a consciência do próprio ritmo do corpo, o que contribui para uma mudança sutil da consciência. A linguagem corporal é um dos meios para o desenvolvimento harmonioso de toda a pessoa.

\section{I.4 A TRAJETÓRIA ESPIRITUAL NO TRABALHO DE BROOK}

A espiritualidade destaca-se na base do trabalho de Peter Brook em busca do sagrado por meio dos ensinamentos conceituais de Gurdjieff, cujos preceitos Brook começou a seguir, durante o ano de 1949, após a leitura de In Search of the Miraculous, de Ouspensky. Sobre seu contato com os ensinamentos do mestre greco-armênio, Brook (2000) relata que teve contato com o livro de Ouspensky de uma maneira bastante inusitada.

Um pouco antes do inglês trabalhar em 1948 com Salvador Dalí, sentiu a necessidade de aprender algumas regras sobre como funcionava o processo de construção da cenografia. Assim, foi para a cidade de Cadaqués na Espanha para trabalhar com o pintor espanhol e se abrigou em uma cabana de pescadores, como pousada. Nesse lugar, aparentemente excêntrico, Brook encontrou um livro chamado: Essai sur le rythme
(Ensaio sobre o ritmo) do príncipe Matila Ghika. Brook havia convidado Salvador Dalí para ser o cenógrafo do espetáculo Salomé na temporada que estrearia em 1949 no Convent Garden. Tratava-se de um espetáculo musical escrito por Wilde-Strauss - uma obra prima do autor, para o diretor. Assim, convidou então, o artista plástico, pois, de acordo com o diretor tratava-se do o único artista que conhecia, cujo estilo natural possuía "tanto a chamada degenerescência erótica de Strauss como a imagística de Wilde” (BROOK, 1994, p.227).

O cenário foi pensado para fazer um verdadeiro teatro musical no estilo dos grandes pintores religiosos, porém a proposta de Dalí remetia a decadência, o sentido obsessivo do erótico e a fantasia imprevisível. O cenário era simétrico e tinha como ponto focal uma laje de pedra velha e caindo aos pedaços enterrada em uma rocha próxima à boca de cena, que dependendo da cena também remetia a uma cisterna. Já os trajes eram rígidos e expressavam o drama. Vale ressaltar que a proposta de Dalí não agradou muito os artistas envolvidos na montagem, uma vez que precisaram ser adaptados, até que os figurinos ultrajantes se tornassem normais e as suas fantásticas arquiteturas inofensivas. Ao que tudo indica, essa parceria também não agradou muito a crítica da época, mas impactou bastante 0 processo criativo de Brook. 
Ao folheá-lo se deparou com grelhas geométricas sobrepostas a edifícios, e medições sobre arcos e colunas clássicas que confirmavam padrões e intervalos recorrentes. Por meio da leitura pode perceber que existiam leis matemáticas e físicas reais que interferiam na harmonia e na organização dos elementos. Foi a primeira vez que Brook teve contato com o termo: proporção áurea, a secreta harmonia entre a proposição das partes.

Desse modo, enquanto trabalhava com designers ou criava seus próprios projetos, percebeu que havia certa combinação entre os elementos e que as escolhas, que pareciam meramente instintivas, indicavam haver uma ordem oculta que a mente conscientemente era incapaz de definir. Essa observação atraiu sua atenção, pois parecia estar diretamente relacionada com a arte teatral. E, conforme relata para Kustow (2005) em Peter Brook - biografia, Brook já havia percebido uma relação entre elementos abstratos no trabalho de Gordon Craig que pareciam sugerir emoções maiores.

Quando encontrou, pela primeira vez, essa expressão de ideias abstratas, se sentiu atraído e fascinado pela beleza desse pensamento. Mas, ao mesmo tempo, não estava convencido de que seria possível separar os sentimentos da ciência, ou seja, o sentimento humano de artistas da análise fria de um cientista. Como não acreditava nessa divisão, pensava que a religião dizia algo essencial, mas da forma errada.

O encontro com o livro de Ouspensky está diretamente relacionado com a tentativa de resgatar o relacionamento com sua ex-namorada, Jean Boulting. Os dois haviam se encontrado, coincidentemente, no mesmo hotel em viagem a Florença. Na volta a Londres, em uma tentativa de salvar o romance, Brook ligou para Jean e se encontraram no apartamento dela. Sobre a lareira, chamou sua a atenção uma crítica de um livro que havia visto na casa dos amigos em Paris, In Search of the Miraculous. Ele pegou o livro e ficou surpreso ao descobrir que havia o mesmo diagrama de uma oitava - os degraus ascendentes e descendentes de toda a energia - que o encantaram no livro de Ghika.

Relata em Fios do Tempo (2000) que, ao folhear o livro, se perguntou que nome estaria escondido por trás da enigmática letra $G$. Jean, naquele momento, explicou que significava Gurdjieff, um mestre que transmitia ensinamentos antigos. $\mathrm{E}$ disse que se Brook estivesse realmente interessado em aprender os ensinamentos, então não deveria recorrer a um livro, mas ter contato direto e pessoal com as fontes do conhecimento. Ela sabia de uma mulher que estava vivendo em Londres e que praticava os ensinamentos do mestre grecoarmênio.

Alguns dias depois, o diretor inglês estava em uma antiga casa londrina em uma rua arborizada e tranquila 
- Hamilton Terrace -, a noroeste da capital inglesa. Ao tocar a campainha, se deparou com Jane Heap, uma escritora norte-americana aos seus sessenta anos. Tratava-se de uma mulher forte que havia desistido de sua vida como editora da revista literária de vanguarda The Little Review para praticar e propagar os ensinamentos de Gurdjieff.

Ao entrar no espaço ouviu

[...] palavras simples que imediatamente soaram verdadeiras, palavras que falavam de uma compreensão que só pode ser comunicada diretamente, nunca pela escrita ou pela teoria, e cujo princípio básico é que nada deve ser aceito passivamente; tudo deve ser questionado e verificado, pois uma verdade só adquire sentido e convicção se for testada, redescoberta e provada passo a passo na experiência própria de cada um (BROOK, 2000, p. 98).

Brook frequentou durante mais de uma década o grupo em Londres, estabelecido por Heap. Como Brook não conheceu seu mestre pessoalmente, sabe-se que foi a partir da leitura do texto e das experiências proporcionadas por Jane, que o encenador logo se interessou pelos assuntos abordados e determinou-se a aprofundar seu conhecimento sobre si mesmo. Heap havia se tornado responsável pela divulgação das teorias gurdjieffianas em Londres. Ela era gentil, impetuosa e compassiva quando necessário dava, eventualmente, em seus ouvintes os choques repentinos de consciência. Ela foi a responsável por apresentar a Brook o pensamento do mentor espiritual, introduzindo ao diretor a relação entre "um mundo ao nosso redor e um universo dentro de nós” (BROOK, 2000, p. 99).

Heap era de estatura baixa, tinha cabelos grisalhos e se vestia como um homem. Foi uma brilhante figura literária em Paris, onde se encontrou com o mestre greco-armênio. Com este contato percebeu que era necessário conferir qualidade de compreensão, de modo que permitisse a ligação do mundo exterior a um mundo de propósito e existência. Teve um efeito significativo sobre Brook, tanto como indivíduo, quanto em sua relação com os outros, ao mostrar que para ingressar no conhecimento não era necessário negar nenhuma das contradições das quais os seres humanos são compostos.

Conduziu o encenador a relacionar os menores detalhes da vida cotidiana às leis e às forças que condicionam toda humanidade. Brook afirma que, por meio do seu contato com Heap, o sentido de tradição havia deixado de ser o conceito antiquado e estéril, o qual ele não apreciava no teatro. Passou a compreender a maneira como os orientais escondiam o conhecimento como uma pedra preciosa, que precisava ser oculta para se tornar difícil de ser descoberta. E, dessa forma, ter o seu valor devidamente associado. Também foi ela quem 
apontou a forma como todas as religiões destroem, rapidamente, a pureza de suas origens ao oferecer prontamente a qualquer um "o que alguém não pode fazer por si próprio sem um árduo trabalho prático" (BROOK, 2000, p. 100).

Desde o primeiro encontro, ela parecia conter as verdades essenciais de uma escola baseada em ideias esotéricas na qual parecia, pela primeira vez, que a realidade superior estava em algum lugar no espaço. Foi nesse contato que aprendeu, também, de maneira gradual, maravilhosa e dolorosa, que o maior obstáculo para a compreensão da verdade seria ele próprio. Pois o sentido espiritual só pode ser encontrado com bastante trabalho, sem soberba ou austeridade. Naquele espaço não havia proselitismo, era exatamente o oposto de uma seita. Era uma verdadeira escola, onde o importante era trabalhar com os outros e não tentar formular a sua própria receita espiritual.

Meu primeiro impulso entusiasta para encontrar o ensinamento espiritual fora desistir de tudo, rejeitar o mundo e dedicar-me a uma vida de busca metafísica, o que me levou apenas a descobrir, para minha surpresa e de certo modo para minha decepção, que não era isso o esperado. 0 sacrifício sem a compreensão leva ao fanatismo, e o primeiro difícil sacrifício que se deve fazer é o da própria avidez, da ideia confusa que se tem do que significa estar "envolvido".
O que, em linguagem esotérica, é chamado de "o quarto caminho" não é nem o caminho da mortificação do corpo, nem o caminho de retirada do mundo, nem o caminho da alta investigação intelectual. É um termo que causou todas as possíveis gradações de incompreensão e distorção - e que requer apenas uma coisa: a compreensão. Isso significa uma compreensão. Isso significa uma compreensão consciente, conquistada de forma independente e que nega a credulidade - uma compreensão que não pode ser alcançada simplesmente por ideias, pela mente (BROOK, 2000, p. I|4).

Brook compreendeu que a religião convencional tentava consolar e, diferentemente dessa abordagem, o trabalho proposto por Gurdjieff seguia justamente no sentido oposto, de incomodar as pessoas para que, a partir da quebra de paradigmas pessoais, ocorresse a transformação. De acordo com ele, Jane certamente seguia o mesmo caminho. Nessa abordagem o mentor não deveria ser obedecido às cegas, mas estar disponível para inspirar, estimular, provocar, acalmar e fornecer condições para que os seus aprendizes pudessem se enfrentar, aprender a se questionar e descobrir como alcançar, com a ajuda de outras pessoas, sua própria intensidade e liberdade.

Por se tratar de um trabalho bastante forte, muitas pessoas perguntavam se sua experiência espiritual 
influenciou o seu trabalho com o teatro. Brook respondia, categoricamente, que foi o contrário, pois jamais se sentiria confortável em utilizar ideias e experiências encontradas em grupo para seu proveito pessoal. Em 1964, após o falecimento de Heap como não havia mais alguém que pudesse orientá-lo em Londres, decidiu ir para Paris onde a obra de Gurdjieff era mantida por Madame Jeanne de Salzmann.

Ela possuía uma fonte refinada de energia pois já tinha atingido o estágio mais avançado do homem harmônico, segundo o ensinamento. Seu corpo era "aberto em sentimento e pensamento" (BROOK, 2000, p. 179). Era uma pessoa iluminada, capaz de desempenhar seu verdadeiro papel. Propagava as teorias do mestre a partir da consciência do que era necessário, depois de ouvir os visitantes que iam à sua procura. Sempre falava diretamente com as pessoas, de modo a evocar um sentimento ou estimular o surgimento de uma ação.

Assim, quatro anos mais tarde, Brook arriscou, com sua esposa, uma nova experiência. Tinham como objetivo "passar mais tempo em Paris, em torno da luminosa presença de Madame de Salzmann, onde um notável grupo de pessoas explorava o rico e complexo material que Gurdjieff havia deixado" (BROOK, 2000, p. 198). Sobre a mudança para Paris, disse a Kustow que, como falava fluentemente e podia pensar em francês, embora não tentasse melhorar $\circ$ seu sotaque, ele se sentia como se fosse, também, um diretor parisiense famoso e talentoso que havia sido inserido em outra cultura.

Deixa explícito em Fios do Tempo (2005) que o motivo de se mudar para Paris não foi o fato de que era uma cidade mais cosmopolita, ou que a Inglaterra destruía seus artistas como havia publicado na revista Encore. Nem a possibilidade de trabalhar com a respeitada produtora Micheline Rozan. Mas a verdadeira causa para a mudança foi poder estar mais próximo de Madame Jeanne de Salzmann, que vivia na Cidade Luz, havia herdado, formalmente, os conhecimentos de Gurdjieff e se tornou a principal transmissora de sua filosofia.

Sobre Madame de Salzmann, afirma que ela era como um leque que se abria aos poucos até que mais e mais fosse revelado. Ela esteve próxima a Gurdjieff desde que se conheceram na sua peregrinação ao Cáucaso, durante a Primeira Guerra Mundial e, por meio de sua incessante batalha pessoal, adquiriu a condição de poder passar os ensinamentos aos demais com a experiência vivida. Certamente havia pelo mundo diversos grupos de estudantes à deriva, em um estado de confusão que precisavam ser acolhidos.

Ao mesmo tempo, existiam diversos escritos que ainda não haviam sido publicados, muitas composições e um número maior de danças, movimentos e exercícios muitos dos quais o único registro era a própria experiência de Madame de Salzmann. No momento 
em que reconheceu todos esses elementos, ela percebeu que sua contribuição era dedicar toda sua energia viajando entre Europa e América para difundir os conhecimentos adquiridos. Assim, Paris se tornou para Brook um mundo de desenvolvimento espiritual. Conforme revela, "eu agora fazia uma promessa a mim mesmo de estar sempre disponível para o surgimento, a qualquer momento, da oportunidade de estar perto dela" (BROOK, 2000, p. I72).

Viver e trabalhar em Paris tornou possível essa condição. Madame de Salzmann, uma senhora de aproximadamente oitenta anos, a essa altura havia alcançado a condição de liberdade com uma vida, dedicava-se aos trabalhos dos ensinamentos aprendidos com seu mestre. Em Fios do Tempo há indicações de que ela estava sempre de modo gracioso para dar as boas-vindas a um visitante. Se sentava de maneira ereta, imóvel e contida, e respondia com riso ou com serenidade. Procurava as palavras e a linguagem precisa para fazer com que seu ouvinte compreendesse a mensagem.

Ela não falava para si, de modo a se deixar levar pelas próprias ideias e lembranças. Tinha uma consciência sobre o que era necessário, a partir de uma escuta sobre o estado da outra pessoa, evocava um sentido ou estimulava que alguma ação ocorresse. Peter relata que ela sempre estava presente, tão próxima quanto a necessidade exigia, e isso muitas vezes gerava uma certa incompreensão por parte dos seus pupilos. Em um de seus depoimentos, diz:

Um dia conversei com a Madame de Salzmann a respeito de uma questão que me corroía constantemente, pois se relacionava com todas as minhas decisões na vida. $\mathrm{Na}$ superfície, tudo parecia equilibrado e harmonioso; com certeza, eu não tinha qualquer direito de reclamar. Mas, no fundo, nada era capaz de extinguir uma sensação de falta de significado, tanto nas minhas próprias atividades, como no mundo à minha volta - contudo, solucionar isso escapando ou desistindo parecia arrogante fútil.

Tratava-se de uma visão pessoal do antigo dilema da determinação [...] "Eu tenho uma busca pessoal pela qual zelo e que respeito, mas também tenho um trabalho na vida pelo qual sou grato e que não posso desprezar. Ambos parecem valiosos, mas de maneira diferente", eu disse.

"O que pode ajudar-me a descobrir quanto eu devo legitimamente dedicar a cada um deles, de modo a manter um equilíbrio?" Ela olhou-me por um momento; então, respondeu de maneira bem simples: "Volte às nove horas hoje à noite." Quando voltei, para a minha confusão, não foi para resumir a nossa conversa, mas para descobrir-me incluído juntamente com outros em uma sessão, guiada por ela, que conduzia, passo a passo, a um silêncio completo.

Eu esperava que algo fosse dito que 
pudesse clarificar a minha questão; somente com o passar do tempo eu entendi o quão precisa e prática a sua resposta aparentemente indireta havia sido. Era a resposta da experiência direta. Tornou-se claro para mim que é a qualidade da vigília silenciosa, informando e unindo o organismo de momento a momento, que dá sentido a cada escolha e a todas as ações. Em um nível normal de consciência, todas as opções sofrerão de uma falta de visão verdadeira e, como eu tantas vezes dolorosamente experimentara, nós nos torturamos com decisões quando, na verdade, não estamos na posição de tomá-las. Quanto mais puro o estado interior, mais clara é a visão. Naquela noite ela levou-nos, passo a passo, a experimentar o que pode ser esse estado, e como, nele, as contradições podem ser resolvidas e as prioridades tornadas reais. Em um estado mais tosco, todos os argumentos são válidos, porque todas as opções são iguais. $\mathrm{O}$ enigma é como descobrir o que pode levarnos a outro estado mais profundo e verdadeiro. Eu ainda acreditava que, de um jeito ou de outro, eu poderia produzir este estado por mim mesmo, e tive que encarar a inconveniente verdade de que mesmo esse desejo natural pode tornar-se $\circ$ maior de todos os obstáculos; até mesmo os desejos mais sinceros podem bloquear aquela especial abertura em direção à qual tendem todas as aspirações (BROOK, 2000, p.I75-I76).
O encenador esclarece que sempre evitou colocar em seus trabalhos os grandes temas simbólicos com os quais se deparava ao se aprofundar nos conhecimentos tradicionais de Gurdjieff. Para ele, a verdadeira tradição era como um rio que vinha de uma fonte distante que, embora se conhecesse a sua origem remota, quando se entrava no rio, suas águas estavam em movimento. Sendo assim, ao entrar no rio também se espera que haja uma adaptação. Em sua opinião, todas as religiões, em pouco tempo, perdiam a sua flexibilidade e o que eram consideradas ideias tradicionais - do cristianismo ou do judaísmo, por exemplo -, se congelaram e se fossilizaram, o que, para ele, serviu como base de ensino para que evitasse resvalar em tais questões.

A separação na utilização dessas temáticas era bastante rigorosa, pois tentava evitar a armadilha de compreender que poderia usar o ensino para o desenvolvimento de seu espetáculo, com o intuito de que chegasse a um resultado melhor. Dizia que, ao trabalhar essa temática no teatro, não queria correr o risco de se colocar em uma posição como se estivesse acima das demais pessoas, por demonstrar que tinha um conhecimento superior a elas. Também não queria ser rotulado como guru, pois para ele muitos atores estavam dispostos e almejavam se tornar parte de um grupo esotérico. Assim, erroneamente, procurariam o aperfeiçoamento espiritual no lugar onde "é necessário manter-se com os pés firmes no chão.” (BROOK, 2000, p. 274) 
Afirma que havia se passado trinta anos desde seu primeiro contato com a temática de Gurdjieff para que cogitasse a junção das duas correntes: a sua pesquisa espiritual e seu aprimoramento teatral. Quando amadureceu a ideia, pode trazer à tona as questões relacionadas à temática sulfi no espetáculo $A$ Conferência dos Pássaros, em 1979. Nesse momento começou a, cautelosamente, acreditar que seria possível o confronto das temáticas. Naquele mesmo ano, ao perceber que Brook estava pronto para trazer à tona a questão do seu aprimoramento espiritual, sua mentora $o$ instigou a transformar o livro Meeting with Remarkable Men em filme.

Trabalharam juntos no roteiro, na escolha dos principais atores, bem como em todos os principais momentos da filmagem das cenas e na aprovação da edição do filme. Em 1985, se colocou, novamente, o desafio de encenar uma peça com temática espiritual, porém com níveis mais profundos de significado, ao encenar o espetáculo Mahabharata, que se tornou uma importante referência ao seu trabalho como diretor de teatro. Em 1990, quando Madame de Salzmann faleceu, aos I0I anos, Brook disse que ela parecia estar levando consigo o centro da vida.

De acordo com o encenador, seu mestre sabia tudo sobre a natureza humana e, portanto, compreendia as pessoas. Afirma que seria errado falar que
Gurdjieff queria iniciar um movimento porque estava constantemente mudando a sua orientação; e exigia das pessoas a sua volta o mesmo que sempre exigia de si mesmo: "encontrar um entendimento que viria de esforços mais profundos e da mais profunda solidão" (CROYDEN, 2003, p. II9). Revelava, ainda, que, por intermédio da solidão, se poderia atingir a independência e a verdadeira liberdade.

Embora os ensinamentos estivessem firmemente enraizados em uma tradição bastante antiga, era possível compreender o seu reflexo contemporâneo. Analisa a situação humana com muita precisão ao indicar que todos são condicionados, desde a infância, a operarem de acordo com as programações que foram arraigadas social e culturalmente, vivendo uma cadeia ininterrupta de reações preestabelecidas. Por sua vez, estas reações produzem um fluxo de sensações e imagens que não são a realidade: são meras interpretações de uma realidade que pretende mascarar constantemente a verdade. Durante um longo período dedicado às aulas, retiros, lições, exercícios e reflexões sobre imagens e histórias paralelas, Brook rompeu seu condicionamento e afirmou a Kustow que, atualmente, não acredita mais em nada. Para ele, permanece

[...] uma imagem que sempre me toca nos ensinamentos antigos é a imagem da escada para o céu. Quando alguém começa a subir, os degraus são firmes, a direção é clara. À medida que se 
sobe, a escada começa a desaparecer. Então, no final, vemos que a escada que subimos com tanto esforço nunca existiu. Crenças são os degraus da escada. Precisamos deles, mas à medida que os agarramos, algo nos diz que eles não são tão sólidos quanto parecem. Nós devemos aprender a acreditar sem acreditar. Caso contrário, a crença é veneno (BROOK apud KUSTOW, 2005, p. 250).

Tinha ciência de que não poderia realizar um trabalho sem estar consciente de que existia uma responsabilidade sobre o que se fazia. $O$ desenvolvimento da pesquisa é o que, constantemente, o levava a campos cada vez mais específicos e profundos. A fórmula para o sucesso estava dividida em três frentes de trabalho na escola do desenvolvimento pessoal: na primeira linha, o trabalho sobre si; na segunda, o trabalho com os companheiros; e, na terceira, o trabalho para o aprimoramento da escola. Promovia-se, assim, condições para que o trabalho seguisse existindo.

Nesse aspecto, de certa forma, as linhas estabelecidas dialogavam com o processo de Brook, tendo como ponto de contato a relação com o desenvolvimento de si mesmo, o relacionamento com parceiros de cena, com o público e com o espaço de encenação. Apesar dessas questões estarem incrustradas em seu trabalho, Brook (apud KUSTOW, 2005) afirma categoricamente que busca evitar, em seu processo, o uso de qualquer ensinamento de Gurdjieff. Afirmação dúbia e contraditória, pois existem certos exercícios e princípios de trabalho, tais como se sentar em um círculo, escutar e fazer exercícios corporais pesados e cansativos, que acabam tendo uma relação natural com os elementos da proposta de Gurdjieff. Assegura, ainda, que jamais usaria o método, o princípio, ou alguma ideia do trabalho do mestre espiritual para dizer que esta é uma estrutura ou uma fórmula que deve ser usada no teatro.

Em relação a criação dos espaços, da cenografia, e dos trajes de cena, deve-se atentar que Brook, ao conceber seus espetáculos, sempre inclui a forma como o público percebe e se relaciona com a presença do ator em cena, bem como os objetivos, trajes e cenários, para que a mensagem transmitida seja condizente com os objetivos do autor e da direção. Consequentemente, é a partir da leitura dos elementos materiais e dos signos colocados em cena, ou seja, é a partir dos elementos visíveis, que associados ao movimento e à interpretação dos atores, que se atinge a imaginação do público e, portanto, se atinge o invisível, ou o sagrado, de acordo com o diretor.

Em 200I, Brook recebeu um convite do Instituto Grotowski, em Wroclaw, para falar sobre as correntes de desenvolvimento do diretor polonês e do mestre greco-armênio. Durante o evento foi questionado sobre a relação dos ensinamentos de Gurdjieff com o trabalho do ator. Nesse discurso improvisado, tentou 
encontrar palavras para o que vinha fazendo há mais de três décadas.

Gurdjieff falou frequentemente sobre como é importante que cada pessoa seja um ator e aprenda a desempenhar seu papel na vida. Mas é importante entender que Gurdjieff não estava falando sobre teatro...

No coração dos ensinamentos de Gurdjieff há uma palavra: "identificação”. Identificação significa algo muito doloroso para nós reconhecermos. Identificação significa que, neste momento, sentado aqui, conversando com vocês, estou totalmente convencido de que a pessoa que fala é o meu verdadeiro eu. Isso não é verdade. Eu estou "colado". Colado ao que estou desenvolvendo neste momento. Eu acredito totalmente nas palavras que estou dizendo, porque estou colado a elas.

Vamos comparar isso com a situação de um ator. Um ator desempenha um papel. Se ele ou ela é realmente bom, todos nós assistindo e acreditamos que cada fibra daquela pessoa imaginária que estamos assistindo é "a personagem". Os atores, de maneira extraordinariamente misteriosa, adaptam seu corpo natural ao corpo da personagem que estão interpretando... $\mathrm{O}$ ator deve estar em contato a cada momento com cada músculo, com seu pensamento e seu sentimento, para que seja possível o corpo inteiro se tornar o todo. Somente então, a parte - nos dois sentidos da palavra - se tornará completamente crivel.

Então, chegamos a algo que é quase impossível de aceitar como conceito. Um ator que está realmente desempenhando seu papel está em ambas as situações: está completamente dentro e ao mesmo tempo distante: envolvido e não envolvido ao mesmo tempo. Em algum lugar no seu organismo há espaço. $E$ deste espaç̧o livre, deste espaço de liberdade, que vêm os impulsos que dão vida à personagem.

Nada pode mudar. Um ator que interpreta Édipo tem que tornar a cegueira de Édipo em relação ao seu passado e o otimismo com que ele enfrenta cada nova revelação tão real que até o público, mesmo sabendo o fim da história, é levado a acreditar que desta vez a tragédia será evitada. Como ser humano, o ator deseja mudar o curso da peça. Toda fibra nele deseja que haja uma saída. Mas, no entanto, o ator sabe que precisa continuar a desempenhar seu papel até o fim. E novamente amanhã. E novamente no dia seguinte. E esse é mais um grau de remoção da identificação.

Gurdjieff usa o ator como uma metáfora para nos ajudar a ver o que um homem plenamente desenvolvido poderia ser. $\mathrm{E}$ isso pode ser facilmente mal interpretado. Ser ator na vida, desempenhar um papel na vida, pode parecer fingir ser algo diferente do que realmente é. Isso é um absurdo. A cada momento preciso, nada pode ser diferente do que o momento contém. 
O desejo de mudar o presente é uma projeção para o futuro, que bloqueia inteiramente nossa capacidade de viver plenamente $\circ$ momento em si, e de fato, viver nossas vidas. No entanto, se alguém é como um ator a diferença é essencial - não se cola à ação, ela se desdobra em liberdade. $\mathrm{Na}$ vida, ouço um barulho terrível lá fora. Corro para a janela para ver o que é. Corro, completamente absorvido pelo movimento repentino e pela onda de sentimentos. É possível fazer a mesma coisa que um ator? Isso significa que a pessoa sentada em silêncio e ouvindo um grito do lado de fora corre para a janela sem ser uma escrava completa das reações.

Em inglês, duas palavras ajudam a deixar isso claro: 'agir' e 'reagir'. Ali todo o tempo, todas as nossas vidas, estamos reagindo... Ali, nossas vidas são reação, reação, reação. Ser capaz de agir é um objetivo muito grande. É o começo de um longo aprendizado. É trabalho.

Então, quando Gurdjieff usou a imagem de ator, não foi com o objetivo de fazer um teatro melhor. $O$ teatro é apenas um campo de investigação muito útil. Gurdjieff chamou de "refletor da realidade". E no refletor podemos ver certos processos que podem nos ajudar, como simples seres humanos, a entender algo mais. A questão imediata é do espaço interior. Somente neste espaço pode existi um eixo central livre. $O$ que pode tornar isso possível? Sou tentado acreditar na força de vontade. Tente você mesmo. Isso não vai funcionar. Algo novo precisa surgir no organismo humano - uma energia mais refinada. Isso é necessário, é essencial que ele entre no campo de outras energias e comece a harmonizar e equilibrar seu funcionamento.

Não posso dizer mais nada sobre isso. Explicações são inúteis. $\bigcirc$ trabalho interior é prático. Abre grandes questões vivas. Este é o ponto de partida de uma pesquisa que ninguém pode realizar sozinho (BROOK apud KUSTOW, 2005, p. 290-292).

A partir dos elementos que foram expostos sobre a relação de Brook com a espiritualidade é importante destacar alguns pontos. Um deles é justamente a relação que se estabelece entre os polos, sagrado e profano, no trabalho do diretor que, muitas vezes, parecem estar relacionados em um dualismo bastante profundo. Além disso, é relevante destacar que ele decidiu alterar totalmente sua promissora trajetória enquanto encenador para poder se aprimorar espiritualmente.

Por fim, fica nítido que Brook só se permite entrar em contato mais direto com a temática simbolista da espiritualidade a partir da montagem do poema sulfi $A$ Conferência dos Pássaros, em 1979. Tais fatores apontam indícios sobre a hipótese, em discussão nessa tese, de que com o seu aprimoramento espiritual há uma efetiva transformação na criação dos elementos visuais do espetáculo, conforme veremos a seguir. 


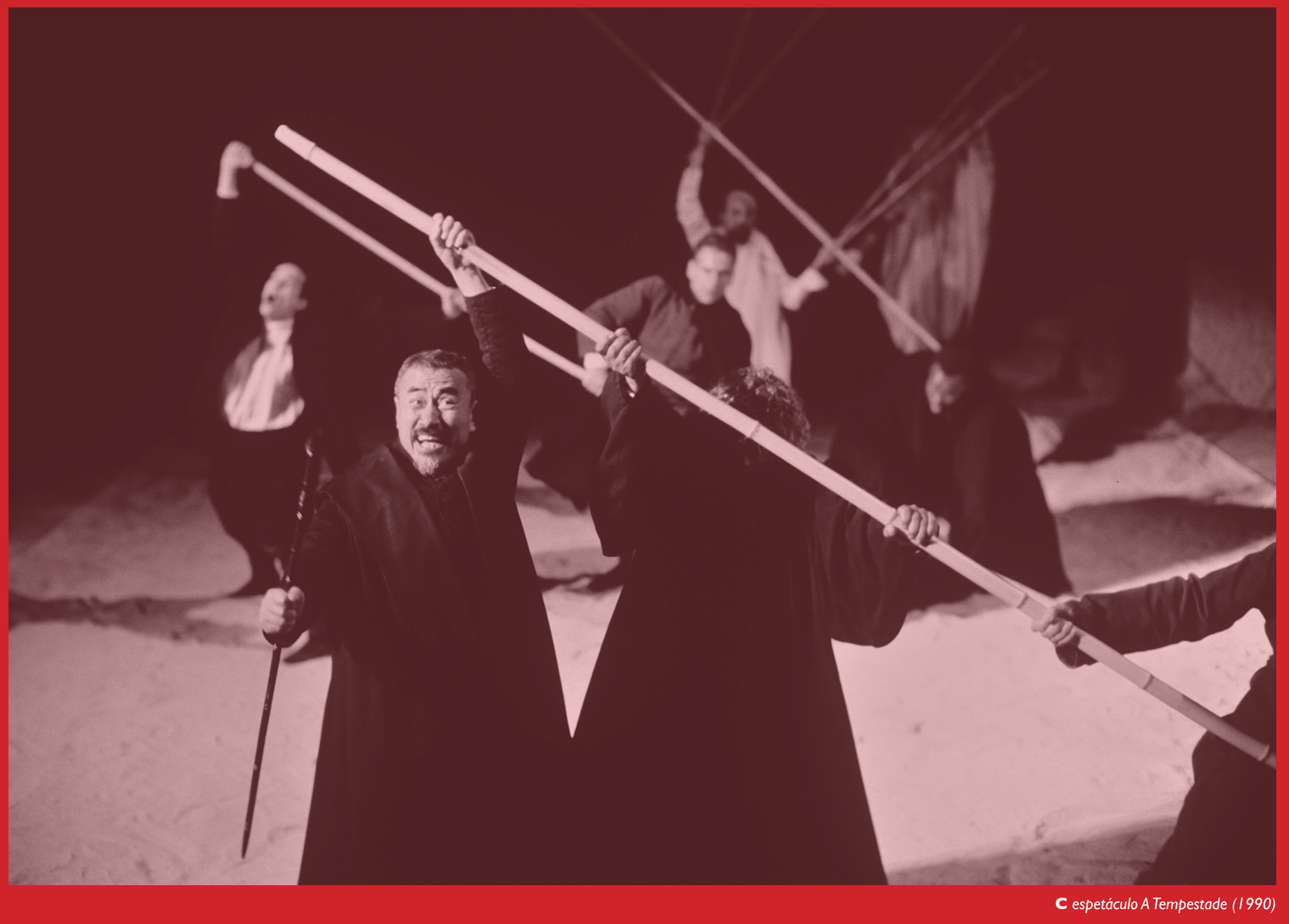





\section{A ESPACIALIDADE EM BROOK E SUAS RELAÇÕES COM A CENOGRAFIA SIMBOLISTA.}

A presente tese defende a transição de Peter Brook de uma cenografia realista e naturalista para outra, simbolista e bastante simplificada com o desenvolvimento da sua espiritualidade. Por essa razão, é fundamental que se compreenda as origens e a evolução destas tipologias cênicas; para que, na sequência, se interprete o processo de transformação da criação espacial do diretor inglês.

\section{I AS ORIGENS DA CENOGRAFIA SIMBOLISTA}

Com a ascensão da burguesia no contexto social e evolução do pensamento positivista, na metade do século XIX, surgiu o movimento naturalista. Em março de 1887, André Antoine apresentou uma pequena adaptação de um texto curto de Zola, pela primeira vez, no Théâtre Libre para um círculo de críticos, fato este que deu início ao que se convencionou denominar como pensamento naturalista. Um dos principais componentes apresentados pelo encenador implicava em uma caixa cênica que mostrava um espaço cênico com bases extremamente semelhantes à realidade.

Desse modo, os cenários não deveriam representar os espaços, mas se tornarem efetivamente os locais onde se passa a ação cênica. Não eram um lugar qualquer, 
mas $\bigcirc$ ambiente exatamente como $\circ$ descrito, em que as histórias ocorriam conforme proposto pela dramaturgia. Pelo pensamento determinista da época, - meio determina fortemente o comportamento psicológico e social dos seres humanos. Portanto, como o ambiente em que se vive condiciona a vida, os cenários eram determinantes para evidenciar a personalidade, as características, os hábitos, o caráter e os comportamentos das personagens.

Assim, o cenário se tornaria indispensável ao espetáculo e sua criação revelaria um processo intenso de preparação e observação, que passaria por uma intensa "pesquisa arqueológica à história social” (MANTOVANNI, 1989, p. 23). Antoine pretendia realizar uma reprodução exata da vida, o que implicava em colocar, efetivamente, no cenário postas de carne crua em ganchos de açougueiro - esta é uma das principais referências utilizadas para exemplificar o significado de cenário naturalista.

Outro representante significativo do naturalismo no teatro foi o russo Konstantin Stanislávski à frente do Teatro de Arte de Moscou, inaugurado com o drama histórico Czar Fiódor Ivánovitch de Alexei Tolstói, em 1898 - período em que o diretor estava ainda bastante relacionado com as pesquisas do teatro realista naturalista. Durante os meses que antecederam a estreia da peça, Stanislávski, Maria Petrovna (Maria Lilina) - esposa do diretor e atris associada ao Moscow
Art Theatre, e o cenógrafo Victor Simov, procuraram vestimentas oriundas dos monastérios e igrejas da região próxima de onde se passava a peça, tinham como intuito reunir material para uma produção de poder emocional e ambiente genuínos.

Stanislávski e seu cenógrafo pretendiam captar o "estado da alma" dos espetáculos de modo a reproduzirem, de forma bastante fiel, o que seria representado. Em 1903, ao montarem Ralé, de Gorki, decidiram investigar os abrigos noturnos, assim, visitaram o mercado de Khitrov e conversaram com mendigos para descobrir como era viver na miséria, para então reproduzi-la em cena, uma vez que o texto retrata a vida dos mendigos. Dessa maneira, atuavam como pesquisadores que analisavam e investigavam a realidade para poder trazê-la para o palco, como é possível observar na figura 2. 
Figura 2 - Cena do espetáculo Ralé de Gorki, encenação Konstantin Stanislávski, 1903.

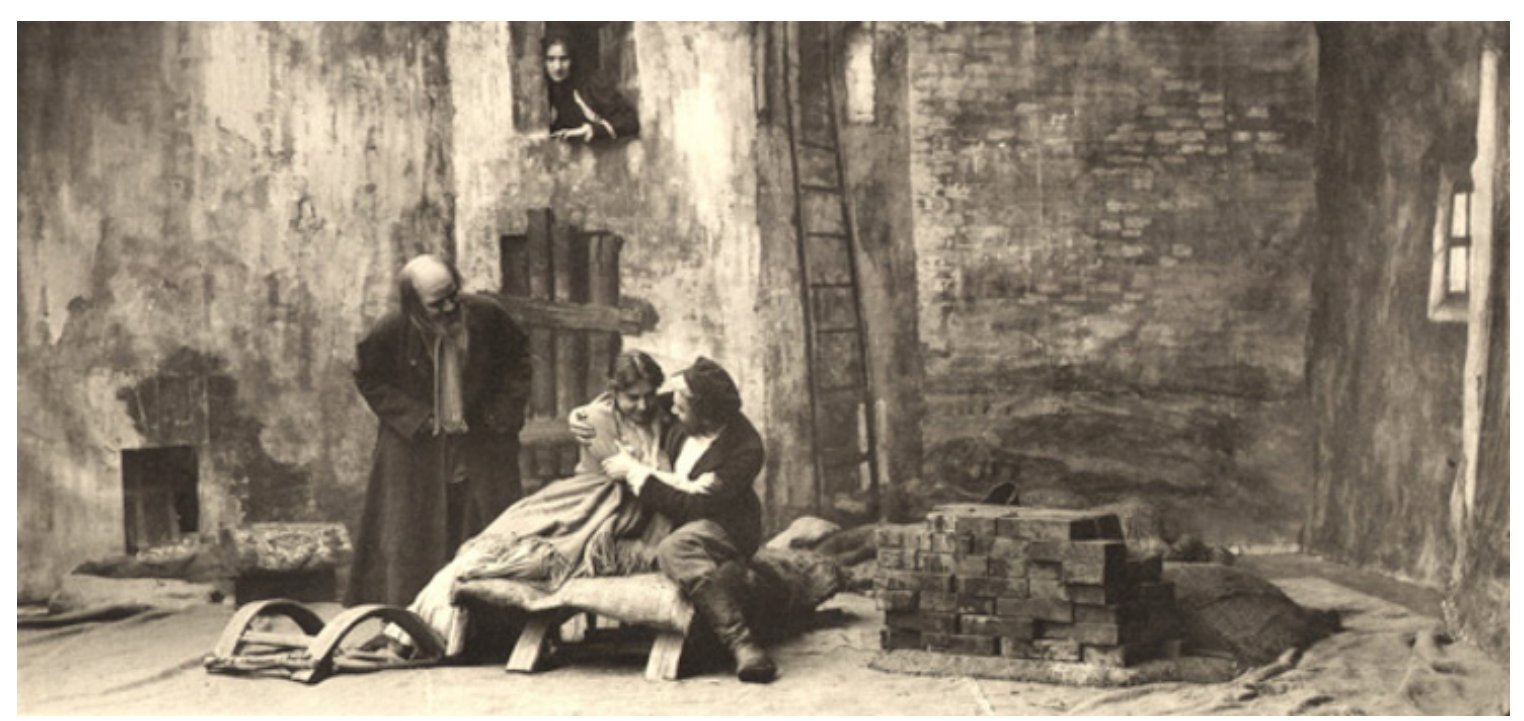

Fonte: Natacha Drama Work (20I2)

É possível então, identificar que a atitude de pesquisar a realidade, iniciada pelo duque Georg II von Meiningen, para a realização de qualquer texto dramático como subsídio para a organização do espaço cênico, passou a fazer parte da representação teatral e, definitivamente, essa análise foi ampliada e aprofundada. Os ambientes passaram a mostrar detalhes do que era possível de ser observado. Buscou-se a precisão na reprodução dos lugares. A exatidão e a autenticidade foram as maiores preocupações da cenografia, de modo que o cenário não representava, mas era o próprio ambiente reproduzido com todos os seus detalhes autênticos. O duque
George Meininger, foi responsável pela companhia dos Meininger, sediada no Teatro da Corte na cidade de Meiningen na Alemanha durante os anos de 1866 até 1914. Esta companhia foi importante precursora da originalidade, coerência e unidade na composição do espetáculo teatral, elaborando um critério estético e estilístico específicos para as suas montagens. Estimulou - trabalho de alguns dos grandes representantes da encenação da sua época. $O$ duque tinha a última palavra em relação a todos os aspectos da direção das suas montagens, esboçava tanto os cenários como os trajes de cena, bem como também determinava a posição dos 
atores em cena.

Dirigiam os atores conduzindo a situação em que estavam os personagens como conseguissem reproduzir o contexto de atuação da situação proposta pela dramaturgia. Há evidências de que o duque mandava executar os cenários, trajes de cena, adereços e móveis utilizados na representação teatral desde o primeiro dia de ensaio, seguindo os seus esboços. Buscava sempre uma fidelidade histórica e textual da cenografia, dos figurinos e dos adereços em busca do realismo ilusionista, do direcionamento da atenção do espectador, do recurso de iluminação, dos efeitos sonoros.

É relevante frisar que os telões pintados, que eram muito utilizados para a composição espacial do palco, foram definitivamente retirados nestas montagens. A iluminação cênica passou, portanto, a ser um dos elementos de composição do espetáculo. De acordo com Mantovanni (1989), a luz indicava, para Antoine a atmosfera pretendida pela encenação, sendo assim, era a alma da encenação. Stanislávski e Simov, no entanto, pretendiam atribuir um tom mais natural à peça, conferindo assim uma diferenciação na iluminação das cenas.

É importante, também, destacar que tanto nas encenações de Antoine quanto nas de Stanislávski, outra premissa do naturalismo estava presente: a indicação de que os atores deveriam representar de uma forma tão natural, como se não houvesse público. Havia, assim, uma interferência direta na maneira de atuar que pretendia que os intérpretes agissem como se a situação representada ocorresse de fato em suas vidas, e o público assistisse ao espetáculo como se fosse um voyeur, vendo a ação como se estivesse olhando através do buraco da fechadura.

Esta determinação cênica, como se na boca de cena existisse uma parede invisível e opaca entre atores e plateia, ficou conhecida como técnica da quarta parede. Ou seja, se estabelecia uma separação formal e radical entre a cena e o público. Desta forma a caixa cênica se tornaria uma caixa ótica, um espaço independente, cúbico e fechado, em que se convencionava uma janela imaginária para exibir a realidade exposta pela dramaturgia.

A crítica começou a questionar e se manifestar contrariamente aos excessos de realidade que eram colocados em cena. $O$ público, que ia apreciar este tipo de espetáculo, era induzido a verificar se a reprodução estava fiel à realidade de modo exato. Permanecia, dessa maneira, apenas como observador, não exercitando a sua imaginação. Desse modo, as reflexões propostas pelos movimentos artísticos relacionadas às artes visuais, quando se descobriu a fotografia, começaram a refletir, também, nas artes cênicas, sobretudo quando 
se começou a difundir os registros cinematográficos. Assim, já no final do século XIX, esboçava-se uma rejeição ao teatro naturalista. No campo das artes, o simbolismo despontou como um movimento antagônico ao neoimpressionismo, ou seja, foi, consequentemente, uma superação do impressionismo.

Este movimento apresentou, também, representantes no teatro e teve como característica relevante a busca da realidade, além do que não estava visível. Tinha a fantasia como fonte para revelar a realidade. Margot Berthold (200l) afirma que o simbolismo teve suas origens em Paris como reação e abandono do naturalismo. Destaca que uma das suas principais reinvindicações era não nomear um objeto, mas torná-lo visível com o poder da imaginação. Para Berthhold (200I), enquanto Stéphane Mallarmé sonhava com um teatro maravilhosamente realista por meio da nossa imaginação, Baudelaire falava da "floresta de símbolos". O universo visível seria um depositório de imagens e símbolos, aos quais somente a imaginação poética poderia atribuir devido status e valor.

Um dos mais jovens simbolistas de Paris, Paul Fort, voltou-se contra o realismo do Théâtre Libre. Com o apoio de um grupo de escritores, que partilhavam das mesmas ideias, fundou o Théâtre d'Art em 1890 e nomeou, como seu diretor artístico, o ator Alexandre Lugné-Poë, que havia começado a carreira ao lado de
Antoine. Nessa ruptura houve uma contundente crítica direta ao naturalismo, com a negação de cenários que reproduzissem partes da realidade. Em suas montagens, Lugné-Poë propunha cenários que evocassem e despertassem a imaginação de seus espectadores.

De acordo com Anna Mantovani (1989, p. 26), “o espetáculo simbolista dá primazia à palavra, e afirma que esta cria a cenografia”. Então os cenários eram extremamente simples, compostos por um fundo pictórico e algumas cortinas móveis que deveriam ser completadas pela imaginação da plateia por meio de analogias expressas pela atuação. Naquele momento, a proposta do teatro simbolista era ser praticamente um teatro mental. Os cenários, em sua grande maioria, eram elaborados por pintores, e as telas expostas se tornavam um produto artístico. A cenografia simbolista passou, então, a destacar a cor como linguagem, tanto quanto a imaginação e a emoção; negando, veementemente, a reprodução fotográfica.

O Théâtre d'Art teve seu centro de gravidade no simbolista Maurice Maeterlinck, poeta e dramaturgo belga, responsável por um drama lírico de solidão e melancolia. A montagem de Pellás e Mélisande em 1893, foi um marco na história do teatro. Com dezenove quadros e dois cenários, sem móveis e acessórios, mas baseados apenas na cor - tons de azul, laranja e verde que traduziam o mistério e a melancolia do texto 
dramático. A luz acentuava o caráter e atmosfera da peça. Contudo a cenografia como ato criativo, com cenários concebidos por meio de uma composição cromática, fez com que o cenógrafo se libertasse das rubricas do dramaturgo.

A repercussão favorável do espetáculo encorajou LugnéPoë a fundar seu próprio teatro, denominado Théâtre de l'Oeuvre, em Paris, que foi inaugurado em outubro de 1893 com a estreia do espetáculo Rosmersholm de lbsen. A trajetória da cenografia voltou a depender das artes plásticas, e o encenador renegava qualquer exagero. Sugeria que os cenários deveriam traduzir e indicar a atmosfera da peça em suas montagens. Contudo, foi o espetáculo Ubu Rei de Alfred Jarry, estreado em dezembro de 1896, que abriu, definitivamente, a possibilidade de se criar outra realidade, com o auxílio de símbolos.

Deve-se destacar que os primeiros a tomar a iniciativa de se recusarem à escravidão dos detalhes realistas foram os simbolistas. Para eles o empenho fotográfico do drama naturalista era uma tela que obstruía o olhar profundo sobre as temáticas exibidas. $O$ palco não deveria apresentar um simulacro da realidade, mas explorar os estados da alma. Sua tarefa não era descrever, mas encantar. A luz passou a adquirir uma função importante. No espetáculo supramencionado, os cenógrafos eram os pintores Sérusier e Bonnard, assistidos por Vuillard, Toulouse-Lautrec e Ranson, que propuseram um cenário único para traduzir visualmente a farsa. $\bigcirc$ ator completava o restante por meio de sua ação, movimento e atuação.

Em um movimento paralelo ao simbolismo pictórico apresentados por Paul Fort e Lugne Poë, destacaramse, segundo Berthold (200I), Adolphe Appia e Edward Gordon Craig, por serem os grandes reformadores simbolistas do palco.

\section{I.I - Adolphe Appia (1862-1928)}

O cenógrafo suíço de origem italiana Adolphe Appia estudou música e escreveu entre outros textos sobre a obra e a teoria de Wagner. Em suas reflexões analisou as peças musicais em relação à situação teatral da época. Sugeriu mudanças que não permaneceram somente relacionadas à cenografia, mas abrangiam os demais elementos do espetáculo teatral. Em seus apontamentos, pretendia chegar a um conjunto harmônico. E, assim, colocava o ator em destaque pois considerava que se tratava de um volume em movimento, que precisava ser considerado como parte do espaço cênico.

Parte de sua preocupação pode ser traduzida por meio da indicação de reforma da encenação, a partir da recusa em utilizar os painéis pintados, ilusionistas e realistas, da época. De acordo com Viana e Campello Neto (2010), em 1895 escreveu A Encenação do DramaWagneriano, em 
que apontou os principais problemas dos espetáculos na cidade de Bayreuth. Os erros fundamentais, para o cenógrafo, eram: os telões pendentes que propunham diversos planos; e, a utilização de um excesso de adereços e decorações que dispersavam a atenção dos espectadores. Interferiam também na interpretação dos atores e obstruíam o conjunto cenográfico.

Neste ambiente, o ator parecia um intruso no espaço cênico. Em seu ponto de vista havia uma falta de equilíbrio visual e harmonia no conjunto. Appia passou a questionar, então, o teatro de palco à italiana como suporte arquitetônico para o espetáculo, sugeriu que o espaço teatral deveria ser adequado e condizente com a nova dramaturgia que surgia. Propôs que o novo local permitisse uma relação distinta entre a cena e o público, sendo um espaço passível de transformações. Em relação à cenografia propriamente, eliminou o excesso e acúmulo de detalhes e discordava em relação à imitação da realidade, considerando que esse tipo de ilusão seria a negação da arte.

Refletiu, também, sobre a maneira como a iluminação era empregada, pois em sua opinião prejudicava ainda mais a cenografia, uma vez que os telões ficavam mais evidenciados como pinturas penduradas no fundo do palco, sem nenhuma integração com o restante dos elementos visuais do espetáculo. Dessa maneira, a relação entre o telão plano e o corpo tridimensional do ator ficava comprometida. Seria impossível procurar uma harmonia entre estes elementos, do modo como eram aplicados na peça era necessário dissociá-los.

Vale destacar que Appia projetou uma série de esboços e maquetes para as obras de Wagner, entre elas O Ouro do Reno em 1892, e Parsifal em 1896. Nessas experiências, atribuiu uma nova tarefa à luz que, até então, não se viu no teatro. Utilizou sombras e projetou o espaço com formas que reforçavam a ideia de profundidade e distância. Com esse propósito, Appia elaborou verdadeiras esculturas arquitetônicas conformadas por blocos pesados, cubos e cunhas, que seguiam o princípio do desenho em três dimensões, ressaltados pelos pontos de luz.

Enquanto Wagner pensava no ritmo da direção teatral, Appia se responsabilizava pela análise do movimento no desenho da peça. Se ele, como visto, pensava o corpo do ator como um volume que se movimentava pelo espaço cênico, logo, deveria fazer parte da composição plástica da cena. A cenografia, por sua vez, não deveria atrapalhar a movimentação, mas auxiliar o desempenho do ator. $A$ impressão visual não poderia mais se fundamentar em um cenário exageradamente detalhado, nem nas imagens pintadas. $O$ protagonismo deveria ser conferido ao elemento principal da criação do espaço teatral: a presença do ator. Era fundamental que o espaço fosse considerado como um elemento 
vivo a ser trabalhado em todas as suas dimensões.

Para Appia (196I, apud DEL NERO, 2009), sem ator não haveria peça teatral e, como cenógrafo ou encenador, suas ações modelavam o espaço teatral. Assim, reformou profundamente a arte da representação teatral, conferindo importância primeiro ao texto dramático, ou musical, e, em seguida, o ator. Alterou, dessa maneira, o espaço de representação que se transformou em um espaço tridimensional, livre dos vícios da caixa italiana, em que a luz ressaltava os volumes colocados em cena.

Suprimiu qualquer elemento descritivo para atingir uma forma plasticamente pura, ou seja, um espaço abstrato com linhas bastante geométricas. Ao organizar o espaço tridimensional, del Nero (2009) destaca que Appia envolveu quatro elementos na sua composição cenográfica: cenários sólidos e planos com verticais lisas; trabalho de piso horizontal; consideração do ator em movimento; e, iluminação do espaço - evidenciando todos os elementos anteriores.

A questão era combinar esses quatro elementos para produzir uma unidade. Todos deveriam estar relacionados e, sobretudo, adequados ao deslocamento e à atuação dos intérpretes. Os elementos verticais deveriam ter pintura plana e serem trabalhados para receber o máximo de luz. A unidade de medida da produção cenográfica era o corpo do ator e como este é tridimensional então, todo o espaço de representação passou a seguir a unidade escultórica e não mais uma composição bidimensional em tela plana.

Os elementos cenográficos deveriam ser completamente funcionais e simplificados: cubos, escadas, biombos, escadarias; e praticáveis com diferentes alturas. Como o intuito principal era colocar o ator em situação, a função dos cenários só se iniciava quando o ator fazia uso deles. Assim, o espaço era organizado com a intenção de atingir o essencial. Eliminou todos os elementos supérfluos, rumo à simplicidade. Segundo Viana e Campello Neto (2010, p. II6),

[...] uma espécie de abstração concreta onde a forma sobrepõe- se ao objeto. Um espaço espiritual em lugar de uma descrição espacial. Uma evocação, que nascida da música e da evolução do ator, funcionaria no espírito do espectador que receberia a mensagem através da funcionalidade dupla desse trabalho estreitamente unido visual e interpretativamente.

Appia era tão envolvido com o estudo da música que se costumava dizer que ele "ouvia" a encenação. Criava escutando as formas no palco e considerava a música o tempo ideal para a atuação, pois envolvia todos os elementos necessários para a ação dramática. Para ele a música, especialmente o estudo com Wagner, conduzia à expressividade. (APPIA apud VIANA; CAMPELO NETTO, 2010). Tinha o poder de inspirar o ator, 
Figura 3 - Esboço do cenário do espetáculo Orpheus, encenação de Adolphe Appia para o Festival de Hellerau de 1913.

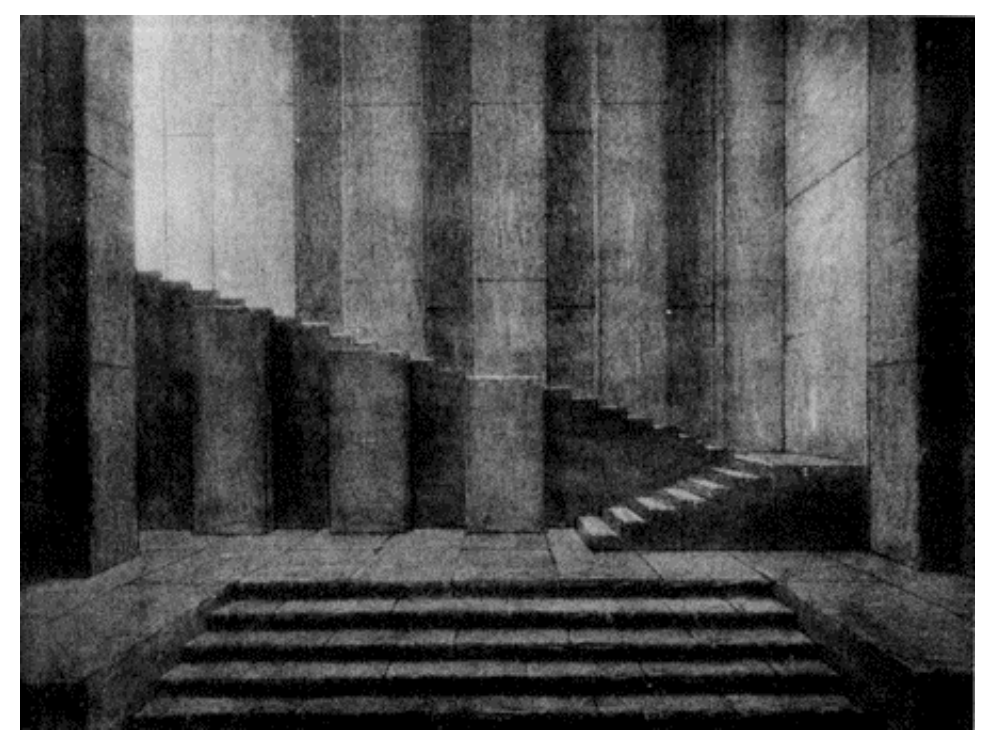

Fonte: Natacha Drama Work (20I2).

instigando movimentos que compunham diretamente com o espaço cênico.

Essa condição proporcionou que o cenógrafo estabelecesse uma hierarquia entre os meios de expressão cênicos definidos pela sequência: ator, espaço, luz e pintura. De tal forma que a luz era o elemento expressivo capaz de estimular o ator a fazer uso do espaço e, assim, conferir vitalidade ao cenário. Apresentava alguns esboços vanguardistas por sua estilização, sendo que eram concebidos com base em formas primárias: muralhas sem definição arquitetônica ou identificação de período, escadarias e rampas que se sobressaiam com os efeitos de luz e sombras. É possível identificar estes traços na figura 3, a cima.

Appia sempre desenhava croquis para as suas propostas cenográficas. Conforme evidencia-se na figura 4, em que a proposta esboçada foi concretizada, é possível distinguir que não havia elementos decorativos. Compunha o espaço em diferentes planos e em diversas alturas para a encenação, que eram interligados por escadas, e estabelecia, ao fundo, um plano vertical com cortinas. Tanto no esboço como na fotografia da encenação, é possível aferir que a iluminação auxiliava a evidenciar a simplicidade dos elementos plásticos pensados pelo encenador. 
Figura 4 - Cenário do espetáculo Orpheus, encenação Adolphe Appia para o Festival de Hellerau de 19/3.

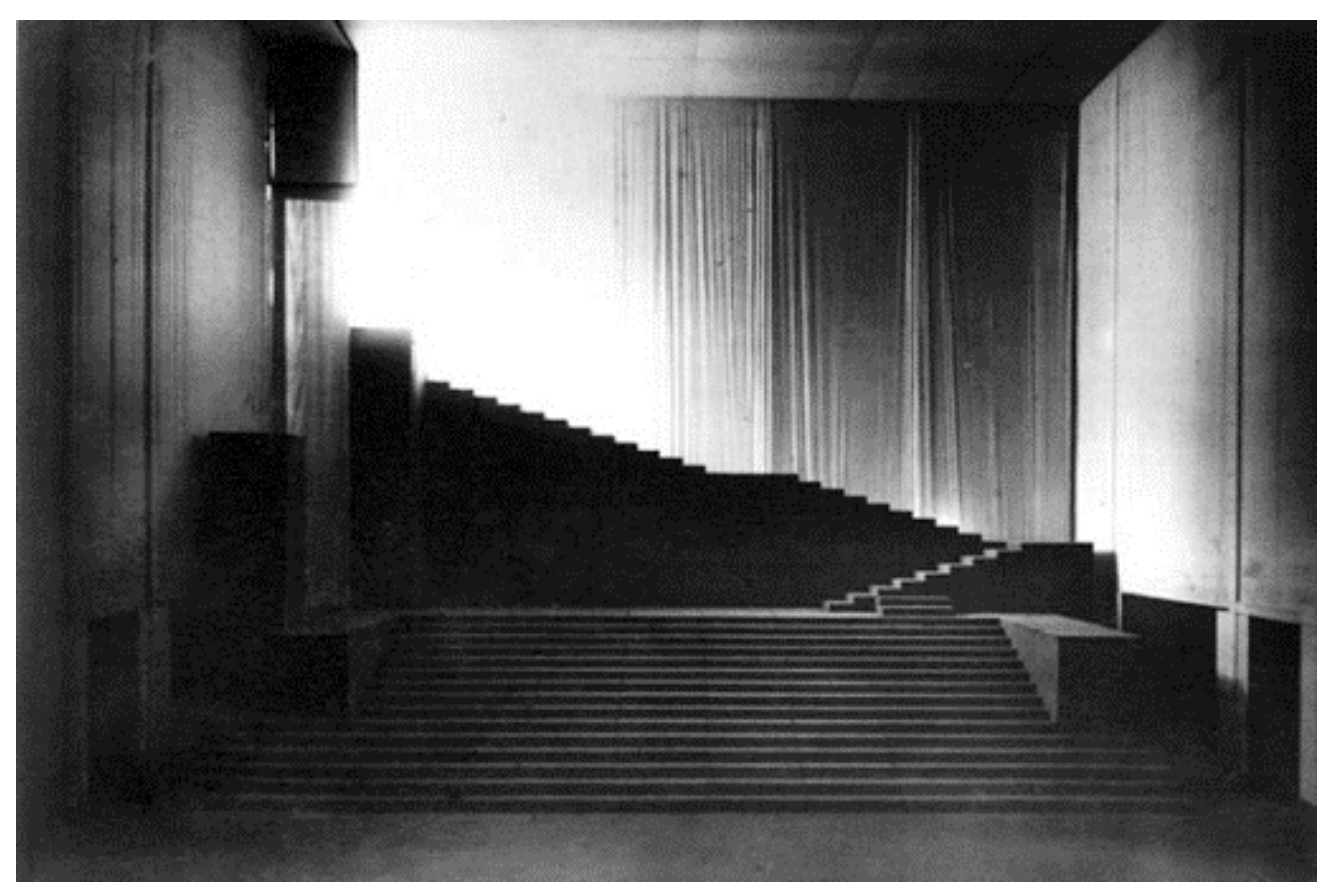

Fonte: Natacha Drama Work (2012)

A composição com a luz tornou-se parte importante na estruturação do espetáculo, um elemento imprescindível na encenação. Sua plasticidade não havia sido explorada anteriormente no palco e passou a ter uma expressiva dramaticidade, de maneira a tornar o espaço vivo e animado. De acordo com del Nero (2009, p. 24I),

Appia distinguia a luz difusa e a luz concentrada. Esta define a forma de um objeto, desenha uma sombra, esculpe diante de nossos olhos, nos emociona dando força e sentido a uma forma: o chiaroscuro de Leonardo e de outros pintores da renascença tornou-se um meio expressivo para Appia: "A luz importante no teatro é aquela que faz sombras. Sem luz sabemos o que são os objetos, mas não sabemos o que expressam".

A implementação da energia elétrica no teatro, com Appia, transformou a atmosfera da encenação. Passou-se a não explorar mais os pontos de fuga nos cenários, mas 
as distâncias sensíveis para cada espectador. Assim a luz deixou de ser somente um efeito estético que conferia cores ao palco e se tornou responsável, também, pela construção das cenas, ao ser utilizada como elemento de união das formas da sua teoria de cenografia. Induzia a evolução despojada das personagens que poderiam se aproximar dos espectadores, entregando seus sentimentos mais íntimos, fortalecendo, assim, a sua capacidade de comunicação. Com a intenção de ampliar este fato, a personagem era acompanhada por uma luz móvel e mutável que lhe conferia vida própria.

Junto com o musicista Emile Jacques Dalcroze criador de um sistema de ensino de música baseado no movimento corporal expressivo -, Appia intensificou a pesquisa rítmica dos espaços - "Espaços Rítmicos" -, com a transformação espacial a partir da relação do corpo humano sob as ordens musicais. Deste modo, o espaço estreitou sua relação com a interpretação do ator e com o desenvolvimento do espetáculo, tornandose extremamente expressivo e emotivo.

Contudo, Appia não ficou preso somente ao seu trabalho com o palco. Propôs uma maior integração com a plateia, mediante a proposta de unificação entre os espaços de representação e o local destinado ao público. Segundo Viana e Campello Neto (20l0), em 1908 sugeriu aos Irmão Morax, para o Teatro de Jorat em Meziéres, a união do espaço destinado aos espectadores com o palco por meio da construção de uma larga escadaria de madeira.

Começou a pesquisar sobre uma teoria de unificação do cenário com a plateia para atingir uma ambientação homogênea entre estes espaços, de modo que o espectador se tornasse participante do evento teatral. Um dos primeiros pré-requisitos de Appia era manter o palco livre para que o ator fosse responsável por complementá-lo, construindo superfícies e objetos imaginários com seu corpo e então estabelecer uma parceria com o público, na qual o espaço permanecesse como um prolongamento do corpo do intérprete.

Gianni Ratto (1999) complementa este pensamento afirmando que o espaço vazio do palco, muitas vezes proposto por Appia, não se tratava de um local adormecido, inerte ou morto. A sua cenografia deveria ser vista como a materialização de um espaço que, mesmo aparentemente vazio, seria preenchido pela expressividade e gestualidade dos atores. Tratava-se, portanto, de "um fenômeno pensante, uma vibração catártica, um espasmo sensorial: fenômeno abstrato, portanto, que nada mais tem a ver com a arquitetura, pintura, materiais, grafia e teorias" (RATTO, 1999, p. 40).

Appia foi, desse modo, o primeiro cenógrafo a sistematizar sua imaginação criativa por meio da música, da luz e das construções tridimensionais. Devido a todo 
este trabalho inovador, influenciou um grande número de cenógrafos e encenadores pelo mundo. Além da proximidade que estabeleceu com Craig, com quem trocou diversas correspondências, um dos nomes relevantes que demonstrou grande interesse em suas pesquisas foi o pintor russo Kandinsky, que realizou alguns trabalhos de cenografia usando o abstracionismo e as pesquisas do cenógrafo suíço como referências.

\subsection{2 - Edward Gordon Craig (1872-1966)}

Edward Gordon Craig foi ator, diretor, cenógrafo, teórico e principalmente artista plástico. Nasceu em Londres e deixou inúmeros textos em que expôs suas reflexões e pensamentos acerca do fazer teatral. Filho da grande atriz inglesa, Helen Terry, iniciou sua carreira como ator chegando a trabalhar sob as ordens de Sir Henry Irving até 1897. Realizou a sua primeira direção em 1893 com Não Se Deve Brincar com o Amor de Alfred de Musset. Posteriormente, fundou sua própria companhia teatral, na qual dirigiu espetáculos como Romeu e Julieta e Hamlet, em 1896, no Prakhurst Theatre.

Com o passar dos anos tendeu mais para a cenografia e direção teatral. Segundo Viana e Campello Neto (20I0), tratou-se do primeiro artista a defender os princípios fundamentais da direção teatral, mesmo quando a profissão ainda não estava consolidada. Foi Craig que instituiu o conceito do diretor como alguém que concebia uma obra artística, escrita por um autor ou dramaturgo que era responsável pela elaboração do um texto literário.

Deixou documentos importantes, como: desenhos, maquetes, fotografias do processo de criação e gravuras, em que é possível identificar como havia concebido algumas de suas cenografias, sonhos e idealizações. De acordo com Viana e Campello Neto (2010), desqualificou o naturalismo como sendo uma mera reprodução: em sua opinião, jamais poderia ser considerado como arte. Se identificou com os simbolistas e defendeu que o teatro se tornasse uma linguagem artística, autônoma e original.

Em relação à trajetória da cenografia vinculada ao Naturalismo, Craig (2017, p. 52) afirmou, em Rumo a um novo teatro e cena, que

[...] houve um tempo em que a cenografia de palco era arquitetura. Um pouco depois, tornou-se imitação de arquitetura; um pouco mais tarde, imitação artificial de arquitetura. Então perdeu a cabeça, enlouqueceu e está em um asilo de loucos desde então.

No texto intitulado A Arte do Teatro, de 1905, definiu que as artes cênicas deveriam ser tratadas como um jogo dos atores, nem da encenação, nem da peça e nem de 
uma dança. Eram compostas pela soma de elementos que a criavam a partir "do gesto, que é a alma do jogo; das palavras, que são o corpo da peça; das linhas e das cores, que são a existência mesma do cenário; do ritmo, que é a essência da dança" (CRAIG, 1963, apud MANTOVANNI, 1989, p. 30).

Diferentemente de Appia, não privilegiou nenhum elemento no fazer teatral, mas valorizou a unidade do espetáculo. Para Craig (1963, apud MANTOVANNI, 1989) teatro significava a união de todos os elementos: as palavras escritas pelo autor e proferidas pelos atores (com seus gestos e movimentos) acrescidas das linhas, cores e materiais dos elementos cênicos; as cores e os tecidos dos trajes de cena; a iluminação artificial e os técnicos, entre outros; sendo que o diretor era 0 responsável por estabelecer a unidade do espetáculo.

De acordo com a proposta supramencionada, o diretor era o criador de tudo e, sendo assim, era incumbido de cuidar da encenação, deveria, portanto, pensar os cenários, luz e figurino. Em busca da unidade e da perfeição concentrou toda concepção do espetáculo, não delegando qualquer função a ninguém. Tratou o espetáculo como um rito "religioso" - uma obra de arte absoluta - assistida de longe pelo espectador. Propôs a autonomia da linguagem teatral, uma vez que não considerava $\circ$ teatro como a união das artes, trabalhando de forma integrada todos os seus elementos.

Em relação à cenografia, indicou uma mudança ao que era desenvolvido na época. Priorizou a verticalidade do palco, e criou painéis móveis (screens) que eram dispostos no sentido vertical; as cores desses painéis, por sua vez, eram simbólicas e deveriam traduzir a atmosfera da cena. Considerou a arte teatral como essencialmente visual, então, deveria atingir os sentidos do espectador, especialmente a visão e, por meio dela, a imaginação.

Não acreditava em cenários que chamassem demais a atenção do público. Procurou a simplicidade e a estilização para atingir o estado de arte e, deste modo, alcançar a revelação e o belo. Utilizou símbolos para encontrar uma unidade e, evidentemente, deu preferência para os elementos visuais em cena. Segundo Mantovanni (1989), a cor em suas obras era responsável por alcançar a sensibilidade do espectador, de modo que permitisse compreender o significado da peça a partir de sua leitura.

A luz, por sua vez, trazia ao espectador uma realidade espiritual, em busca da beleza absoluta. Em o Ator e a Supermarionete (1907) Craig sugeriu a substituição do ator e defendeu a utilização de uma übermarionette (supermarionete) em cena, uma proposição caracteristicamente simbólica. A supermarionete eliminava a figura humana para recompor a cena de 
maneira magnífica, quase grotesca. De acordo com Silva Filho (20I4), o diretor falava simbolicamente sobre uma libertação dos atores de suas próprias vaidades e do enfrentamento de suas deficiências.

A teoria da supermarionete foi elaborada com o intuito de eliminar todos os traços de egotismo dos atores. Assim, desafiava os intérpretes a buscarem a perfeição técnica adequada e necessária a tudo o que é sublime na arte, de acordo com os conceitos simbolistas. Defendeu um teatro ritualístico e, assim, caminhou em direção ao sagrado.

O teatro simbolista era $\circ$ produto da crença de que a arte, e com ela o teatro, era não só uma experiência estética para aqueles que a faziam e assistiam, mas também uma oportunidade de busca metafísica e descoberta espiritual (EYNATCONFINO, 1987 apud VIANA, 2010, p. 40).

Craig tinha preferência por dramaturgos com grandes curvas de emoção. Era encantado pela ideia de transformar as linhas do texto em luz e espaço para espiritualizar o realismo cênico. Discutia se o ator deveria se identificar ou se distanciar da personagem e, também, sobre a ilusão do naturalismo e do estilismo cênico. Quando começou seu trabalho como diretorcenógrafo, pairava uma intensa reação contrária ao que se chamava de cena fotográfica, e o diretor inglês se tornou um dos principais questionadores dessa forma de produção.
Para Viana e Campello Neto (2010), sua direção foi sempre assinalada por uma cenografia de grande impacto e, em muitas vezes, o texto passou a ter uma importância secundária em relação à dinâmica da peça. Dentre os seus trabalhos mais significativos destaca-se a montagem de Rosmersholm escrita por Ibsen, em 1906 na cidade de Florença, na qual realizou a cenografia e teve como uma das intérpretes a renomada Eleonora Duse. Esta peça ficou registrada como um dos maiores momentos da história do teatro, no princípio do século $\mathrm{XX}$.

Ao longo de 1907, ainda em Florença, teve a possibilidade, durante dois meses de tomar notas, desenhar e realizar algumas gravuras, que foram reunidas num volume chamado Scenes - trabalho este que representou a sua nova visão sobre o teatro. Ainda no início daquele século, outra obra importante desenvolvida por Craig, como cenógrafo, adveio de seu encontro com Stanislávski no Teatro de Arte de Moscou. Em 1908 trabalharam juntos por dois meses, quando o encenador russo, estava em busca de uma forma mais expressiva para a interpretação, onde a cenografia, aplicada às novas formas estruturais se tornasse parte significativa da sua teoria de encenação. Craig foi convidado, então, para realizar o cenário de Hamlet.

A proposta de Craig idealizou painéis dourados que representavam a riqueza da corte e, em contrapartida, 
outros painéis, na cor cinza, como símbolo da tristeza da alma de Hamlet (figura 5). Não utilizou nenhum outro elemento que descrevesse a cena, somente os painéis com as distintas cores. De acordo com del Nero (2009), este espetáculo foi um fracasso enquanto cenário, mas uma verdadeira vitória na história da cenografia, pois as conquistas artísticas de Craig não puderam ser medidas de imediato, nesse caso.

A composição apresentava vinte cenas com painéis que não se moviam com facilidade, nem eram de alturas iguais, o que causou uma grande confusão de entradas e saídas dos atores. Apesar da grande experiência teatral do ator, diretor e cenógrafo Gordon Craig, esse cenário se tornou impraticável também porque a fluidez de Hamlet não colaborava com o sistema visionário da cenografia. Vale ressaltar ainda que naquela época não havia tecnologia teatral disponível para auxiliar a sua execução.

Figura 5 - Esboço do cenário do espetáculo Hamlet, elaborado por Craig e encenado por Stanislávski.

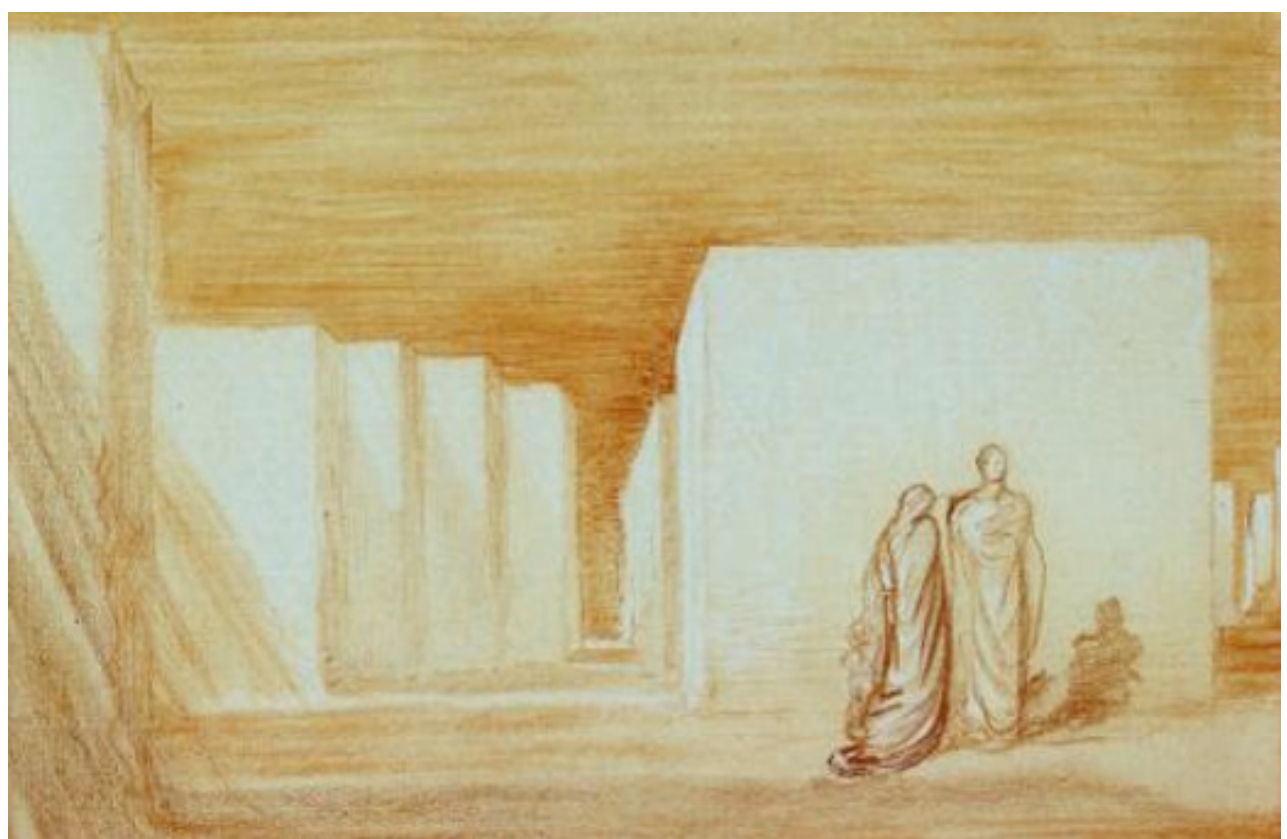

Fonte: Del Nero (2008). 
De acordo com Berthold (200I), Craig concebia suas propostas de palco não somente como iluminador, com a qualidade do simbolismo transformando a luz mas, da mesma forma, como arquiteto, criando ambientes por meio do jogo de luz e sombras. Dessa maneira, os painéis da montagem de Hamlet definiam ambientes e traziam outros significados que não apenas uma monumentalidade vazia.

Além das informações supracitadas sobre as cores do cenário, os painéis pretendiam, ao mesmo tempo, apagar o efeito visual da tradicional caixa cênica para realçar, com a imponente mobilidade, as ações dos atores e fornecer aberturas com alturas variáveis que reagissem às sucessões de luzes desenhadas. Sobre os preparativos para a encenação, Stanislávski (apud BERTHOLD, 200I, p. 47I) afirma:

Craig pensava num espetáculo sem intervalos nem cortinas. $\bigcirc$ público chegaria ao teatro e não veria palco ou coisa parecida. Os biombos funcionariam como o prolongamento arquitetural da sala dos espectadores e se harmonizariam com esta. Mas no início da apresentação os biombos se movimentariam graciosa e solenemente; todas linhas e agrupamentos transpor-se-iam de um para o outro, até que se fixassem por fim em novas combinações. De algum lugar, acender-se-ia a luz que projetaria sobre elas efeitos pictóricos, e todos os presentes no teatro seriam levados, como num sonho, para algum outro mundo somente insinuado pelo artista, mas que se tornaria real pela virtude das cores da imaginação dos espectadores.

Além desse registro, conforme expõem Viana e Campello Neto (20l0), Stanislávski afirmava que Craig evitava as imitações de papelão; preferia utilizar madeira rústica, metais e materiais orgânicos, escolhendo-os por sua textura e densidade, para seus projetos de cenografia. "Marcou sua obra com um despojamento usando material puro, dando-lhe um impulso majestoso até o absoluto" (VIANA; CAMPELLO NETO, 20I0, p. 125).

É importante destacar a admiração de Craig pelo talento e pelas obras de Appia. Eles trocaram muitas correspondências, enquanto o cenógrafo suíço ainda vivia. Além disso, toda a atividade de Craig como cenógrafo suscitou algumas inovações e renovações importantes para o contexto do teatro moderno, fatos estes que influenciaram outros artistas empenhados na renovação teatral e que, ocasionalmente, seguiram suas orientações, como é o caso de Max Reinhardt.

Conforme expõe Pavis (20l I), tanto nos princípios de Appia como nas teorias de Craig, a cenografia tornouse, pela primeira vez, fundamental na representação. Ambos se colocavam avessos às encenações naturalistas que faziam do ambiente da personagem 
uma réplica passiva e mimética da realidade. Foram mais importantes por seus projetos, esboços e reflexões, do que propriamente por suas realizações concretas, ainda que estas tenham muita relevância para as investigações teatrais. Foram reais reformadores dos princípios teatrais, pois ampliaram de fato a concepção completa da encenação.

Como pilar central sobre a estética cenográfica, para ambos, estava o valor rítmico do espaço, que não era mais de um objeto bidimensional, fixo nas laterais e ao fundo do palco, mas tratava-se de um "corpo vivo submetido ao tempo, ao tempo musical e às variações da luz" (PAVIS, 20II, p. 46). A cenografia passou a ser considerada, por influência do simbolismo, não mais um objeto que deveria ilustrar ou reafirmar o que era expresso no texto, mas como parte integrante do universo de sentidos expresso pela dramaturgia.

A arte da encenação, para Appia (1921 apud PAVIS, 20II), era a arte de projetar no espaço aquilo que o dramaturgo só pode projetar no tempo. Era tornar visível, um texto ou uma música por meio das ações sensíveis do corpo humano, às resistências propostas pelos planos e volumes construídos. Desse modo era essencial que a iluminação tivesse um papel ativo na concepção espacial e que o palco estivesse livre de toda decoração supérflua à representação teatral, e dos telões pintados.
O ator era o protagonista, estava no centro desse espaço animado pela luz. A cenografia era composta por volumes maciços e versáteis. Escadas, plataformas, pilares e biombos projetavam suas sombras de maneira que o corpo do ator estivesse inserido em uma ordem musical e arquitetônica. "O espaço é assim uma paisagem mental, uma arquitetura perfeita, o sonho ou a música tornam-se forma, a ideia matéria, o texto revive no universo rítmico do tempo e do espaço" (PAVIS, 20I I, p. 46).

Por sua vez, Craig compartilhava com Appia a negação da pesquisa histórica exata, a ilustração pictórica e a encenação distorcida pelo ator-vedete. Assim como o encenador suíço, admirava também a obra de Wagner. Dividiu a ideia de que a cenografia deveria ser autônoma e propagava a necessidade de síntese dos elementos da representação. Enquanto Appia conferia ao ator um papel central na estrutura do espaço e do tempo, Craig pretendia que o ator fosse neutralizado, fator que resultou na sua teoria da supermarionete, elaborada não como elemento para substituir o ator, mas para evitar as voluntariedades de um ser humano submetido às emoções, ao acaso, e à improvisação própria da matéria viva. Não resta dúvida, portanto, de que foram grandes renovadores da cena no século $X X$. 


\section{2-AMANEIRACOMOBROOKCOMPREENDE CENOGRAFIA E OSTRAJES DE CENA}

Para compreender a forma com que Peter Brook se relaciona com o pensamento dos encenadores simbolistas, sobretudo Appia e Craig, é importante saber como ele pensa a transformação do espaço cênico, bem como idealiza a cenografia e os trajes de cena em seu trabalho. É igualmente significativo entender a maneira como evoluiu seu processo de amadurecimento como encenador teatral, responsável pela elaboração dos elementos visuais do espetáculo.

Enquanto ministrava palestras para divulgar sua pesquisa sobre o espaço vazio, em 1991, Brook foi questionado sobre o edifício teatral com seu palco italiano. Para ele as relações desse formato de palco e as soluções cênicas desse modo de produção já estavam esgotadas. Sendo assim, era fundamental experimentar novas possibilidades. Naquela ocasião sugeriu que fosse elaborado um novo tipo de teatro, em que a caracterização psicológica das personagens tornasse visível a "invisível” alma humana, o que ele determinou como sendo os princípios do Teatro Sagrado.

A partir dessa sua crítica, despontaram em todo o mundo novos experimentos, com formas e espaços alternativos, buscando variações na produção cênica.
Para que alguma coisa relevante ocorra, é preciso criar um espaço vazio. O espaço vazio permite que surja um fenômeno novo, porque tudo que diz respeito ao conteúdo, significado, expressão, linguagem e música só pode existir, se a experiência for nova e original. Mas, nenhuma experiência nova e original é possível se não houver um espaço puro, virgem, pronto a recebê-la (BROOK, 2005, p. 4).

No começo da década de 1970, realizou algumas tentativas de encenação fora dos edifícios convencionais.

Nos primeiros três anos fizemos centenas de apresentações nas ruas, em cafés, em hospitais, nas antigas ruínas de Persépolis, em aldeias africanas, em garagens norteamericanas, em barracões, entre os bancos de concreto de parques municipais, mas a experiência mais importante para os atores foi a de representar para um público que eles podiam ver, ao contrário da plateia invisível a que estavam acostumados. Outra característica importante para esse tipo de espaço é que o vazio é compartilhado: o espaço é o mesmo para todos os que ali estão (BROOK, 2005, p. 5).

Com o grupo formado por atores do Centro Internacional de Pesquisa Teatral, transformava em teatro qualquer espaço vazio. Bastava que algumas pessoas se reunissem em algum lugar, não importava onde, e que alguém contasse uma história para que, 
naquele espaço, se convencionasse a ação teatral. Embarcaram em algumas peregrinações pela África, Oriente Médio e Índia, iam de aldeia em aldeia, sem ideia de qual seria o motivo da proposição cênica.

Poderia ser uma música, um movimento, ou uma improvisação. Esse risco proporcionou, para o diretor, os melhores resultados, uma vez que tornava o ato de se fazer teatro um diálogo direto com a plateia. Assim, toda encenação iniciava-se com os atores sentados em círculo sobre um tapete que transportavam, envolvidos por aproximadamente duzentas pessoas reunidas em seu torno.

Um dos atores começava a caminhar sobre o tapete. $O$ ato de caminhar levaria uma segunda pessoa a andar sobre ele também, e a partir da relação estabelecida pelos atores extrairiam uma reação do público. Nesse contexto, evidentemente, estavam conectados com a tradição dos grupos de teatro popular, embora esse não fosse seu objetivo final. Os atores sobre o tapete dispunham de total liberdade para criar e sempre eram acompanhados por uma resposta contínua do público.

Conferiram a essa experiência o nome de The carpet show ( $\bigcirc$ espetáculo no tapete), identificável na figura 6 . No evento, o tapete servia como demarcação da área de trabalho. Sobre ele poderiam testar, em qualquer parte do mundo, as bases técnicas do teatro shakespeariano, por exemplo. Descobriram "que o melhor modo de estudar Shakespeare não era examinar reconstruções de teatros elisabetanos, mas simplesmente fazer improvisações sobre um tapete" (BROOK, 2005, p. 24). 
Figura 6 - O ator Andreas Katsulas na realização de um carpet show na África.

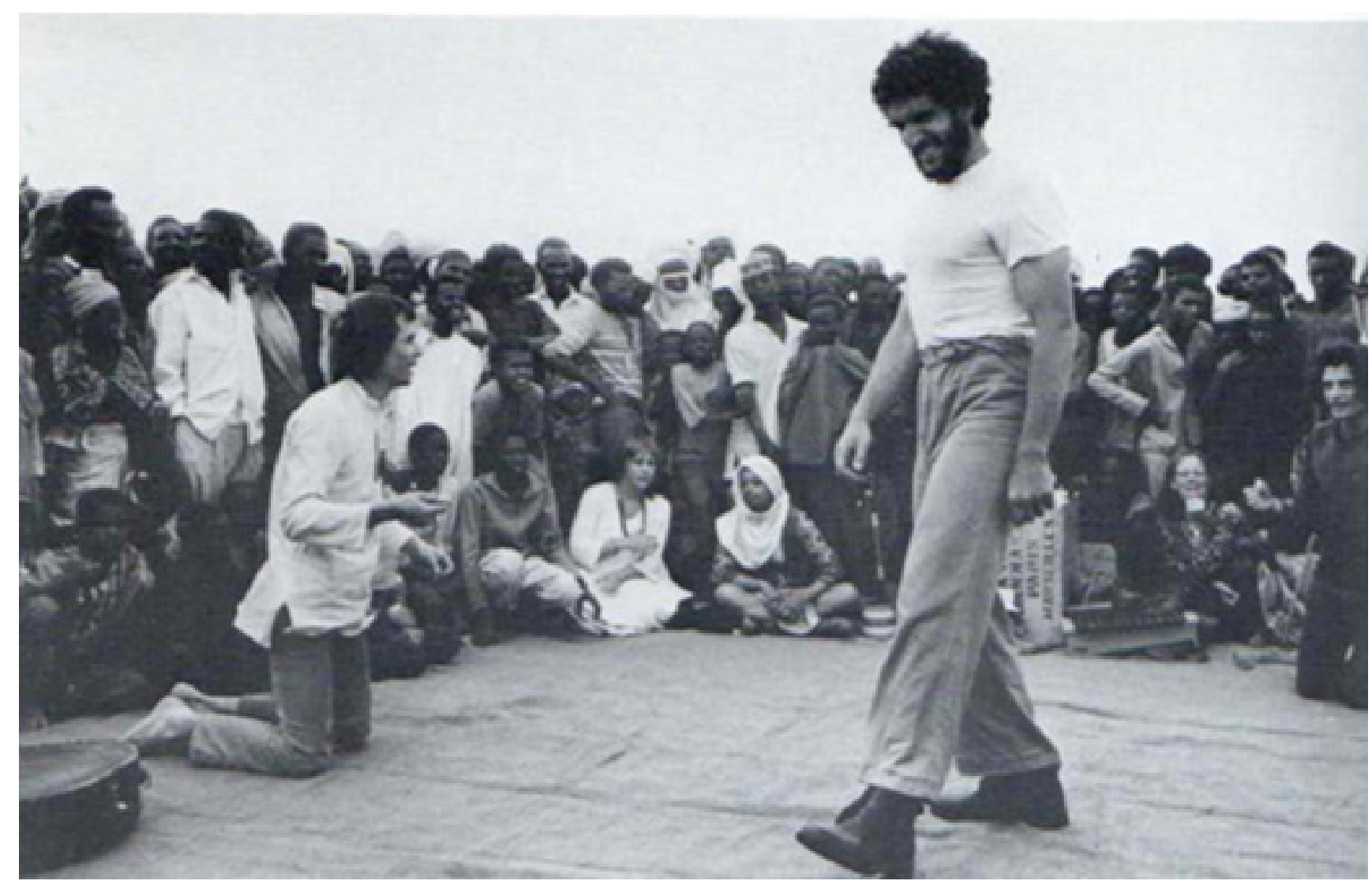

Fonte: Heilpern (1978, p. vi) 
Todavia, foi no Teatro Bouffes du Nord que encontrou - lugar ideal para desenvolver seus projetos. Tratase de um edifício teatral que foi projetado, em 1876, por Louis-Marie Émile Leménil, um arquiteto pouco conhecido, que também foi responsável pelo projeto do edifício de apartamentos localizado à sua frente, de maneira a esconder o edifício teatral (figura 7).
Antes da reforma proposta por Brook, o formato original era de um teatro convencional em formato de ferradura. Porém, diferentemente dos teatros italianos cujo eixo mais longo é perpendicular ao plano no proscênio, no Bouffes a elipse que confere o eixo da ferradura é rotacionada em 90 graus, o que faz com que o seu eixo mais longo fique paralelo ao proscênio. Essa característica fez com que as linhas de visão do teatro

Figura 7 - Planta do Théâtre des Bouffes du Nord antes da reforma proposta por Brook.

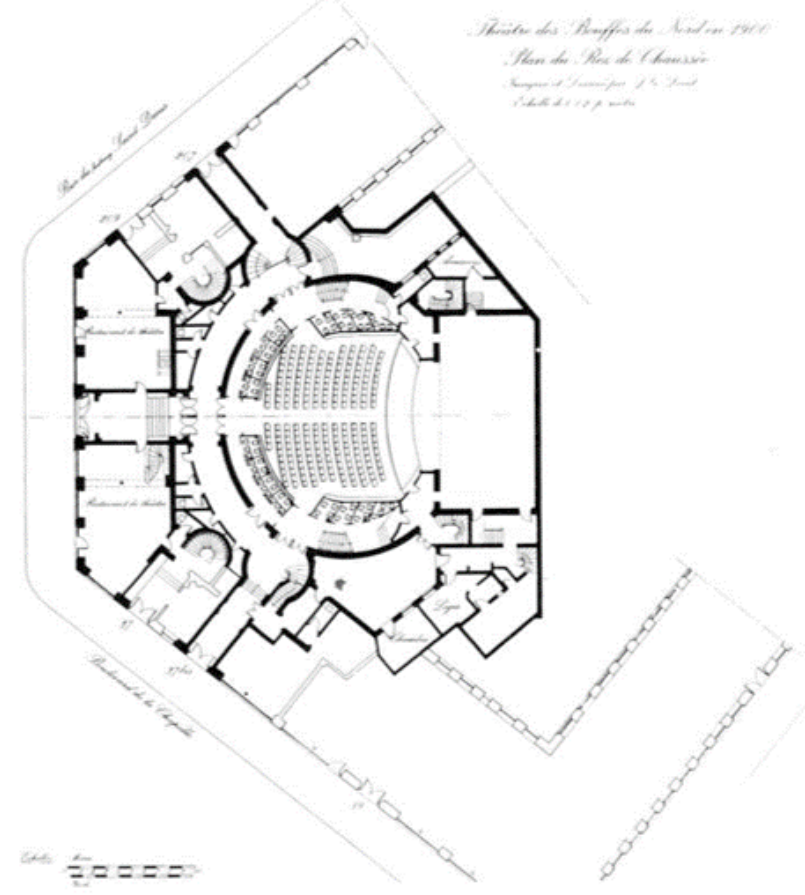

Fonte:Todd; Lecat (2003, p. 14) 
original fossem extremamente ruins para a maioria do público que se sentava em suas laterais.

Localizado em uma região operária de Paris, na Place de la Chapelle próximo à estação Gare du Nord, o Bouffes du Nord, tinha abrigado estrelas do music-hall e foi um local para as produções de lbsen, na virada do século XIX. Quando Brook chegou ao teatro, observou sua estrutura arruinada, com pisos e paredes manchados e maltratados, e o seu interior sem ornamentos, exceto os balcões da ferradura - que tinham conseguido reter um pouco de sua glória passada -, compreendeu as possibilidades que o espaço poderia oferecer e decidiu alugá-lo.

Ao eleger colocar suas produções dentro daquelas paredes decadentes e escolher esse teatro em ruínas como sede, Brook desmistificou a ideia de que seria necessária uma casa grande e ostensivamente decorada, equipada com tecnologia moderna, para se ter um bom teatro.

O que é um "bom" espaço? Primeiro de tudo, não deve ser frio. $O$ Bouffes é quente, por causa de suas paredes que carregam as cicatrizes e rugas de tudo o que tem ocorrido através de mais de um século de altos e baixos. Um bom espaço não pode ser neutro, a esterilidade impessoal não dá alimento para a imaginação. $\bigcirc$ Bouffes tem a magia e a poesia de uma ruína, e quem já se permitiu ser invadido pela atmosfera de umas ruínas sabe quão fortemente a imaginação fica solta.

Um bom espaço é íntimo: é uma sala em que o público senta-se com os atores e os vê de perto, mostrando o que é verdadeiro na atuação e revelando impiedosamente o que é falso. No entanto, um bom espaço é mais do que isso - é um desafio, convidando os atores a irem além de si mesmos, além de um naturalismo cinematográfico. $\bigcirc$ Bouffes é ao mesmo tempo um espaço íntimo e épico. Sua relação com o anel de espectadores envolvendo os atores é próximo e fácil. Mas os seus arcos crescentes, suas proporções como uma mesquita, tornaram-no muito exigente. Excepcionalmente, é um interior bastante escuro e ao mesmo tempo um pátio iluminado pelo sol (BROOK apud TODD; LECAT, 2003, P. 25).

Conforme expôs a crítica teatral Croyden (2003), o Bouffes tinha uma aura única, a qualidade indefinível, estranha e misteriosa. Algo de belo em si mesmo, que vai além da atmosfera apenas romântica de se ocupar um antigo teatro abandonado. Suas proporções tinham uma relação com o rigor matemático, que conferiam uma harmonia ao ambiente. Conseguia identificar essa qualidade do espaço devido ao seu contato com a teoria da Proporção Áurea, exposta no capítulo anterior.

De certo modo, por decisão do próprio diretor, ao determinar que os atores e a plateia estariam no 
mesmo espaço colocando o nível da representação no mesmo dos assentos, contribuiu significativamente para - ajuste da estrutura espacial do teatro. Ao eliminar o fosso que separava o palco da plateia (figura 8), e reduzir a capacidade máxima de aproximadamente mil para quinhentos espectadores, colaborou para o aprimoramento da qualidade de apresentação do espaço.
Dos duzentos metros quadrados de área de atuação, segundo Todd e Lecat (2003), em The Open Circle, somente quarenta metros quadrados eram perfeitamente visíveis de todos os pontos da sala. As demais cadeiras tinham sua visão comprometida. Ao realizar a mudança do espaço, além de nivelar os ambientes de representação e a sala dos espectadores, Brook estabeleceu "um espaço teatral com dupla

Figura 8 - Área reformada do palco do Théâtre des Bouffes du Nord com a utilização dos balcões originais

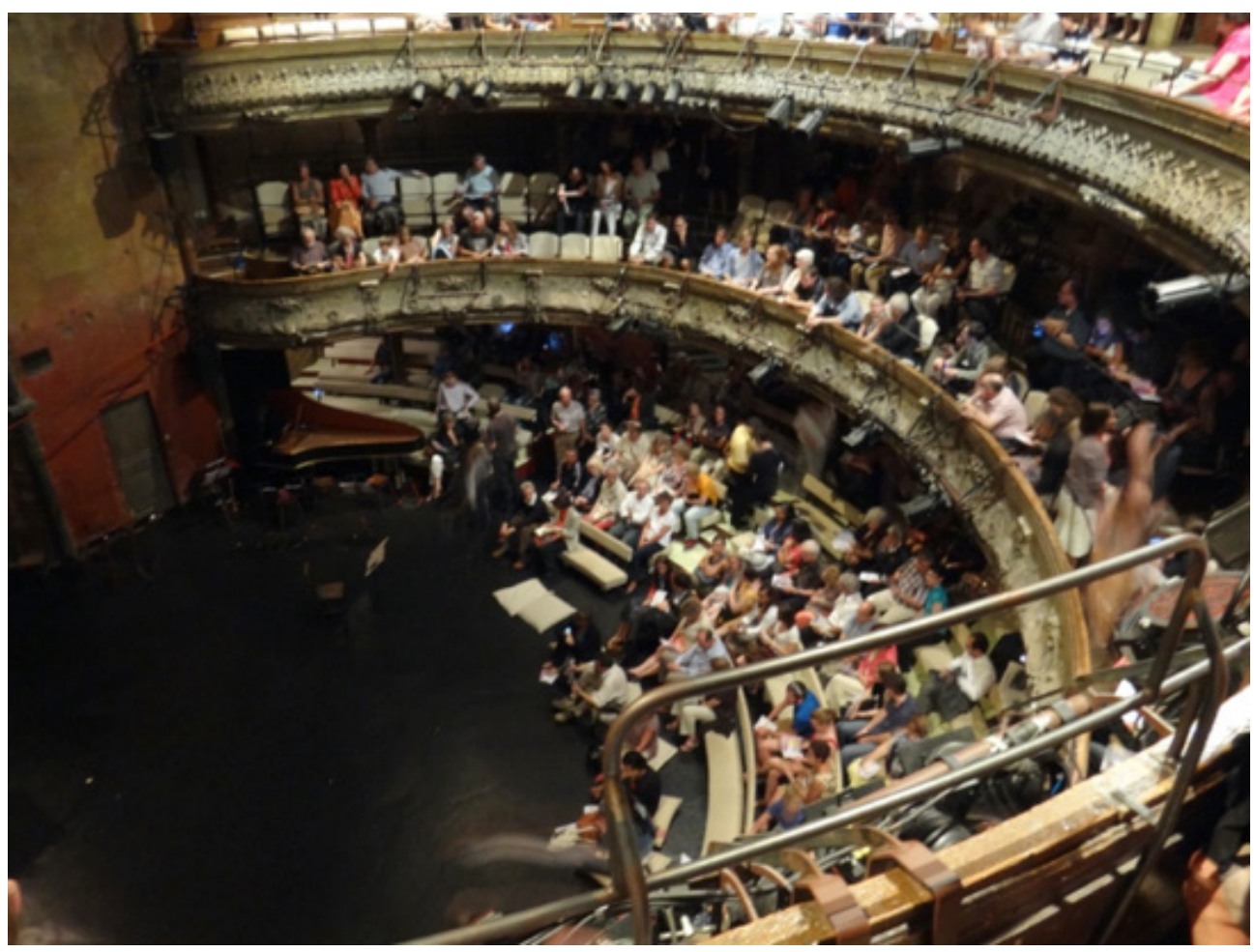

Fonte:Acervo do autor (2012). 
profundidade [...] articulada" (TODD; LECAT, 2003, p. 27). Esta nomenclatura se deu em função da conexão dessas duas grandes áreas. A primeira delas tratava do novo palco em formato circular para a representação em frente ao proscênio, rodeado pelo semicírculo da audiência (figura 9) - proposto devido à maneira de atuação do grupo.
O outro espaço tratava-se do que permaneceu do palco anterior, ou seja, a área onde se conformava, anteriormente, a boca de cena delimitando a quarta parede, ou o que os franceses chamam de "gaiola"" (figura 10). Sua parede dos fundos, onde era colocado o ciclorama ${ }^{10}$, tem onze metros de altura por dezesseis metros de largura. Com a reestruturação espacial, o

Figura 9 - Área de atuação com a não delimitação do proscênio do palco.

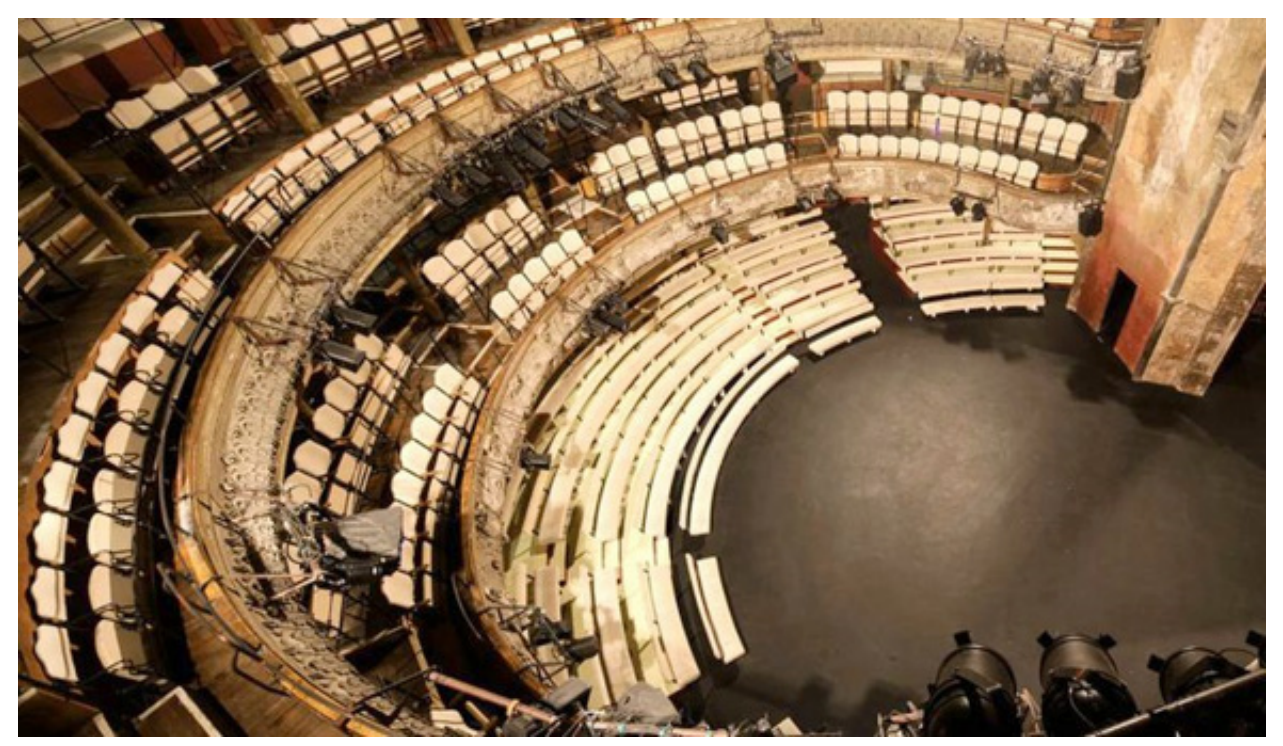

Fonte: Dray (2018).

${ }^{9}$ Gaiola é a nomenclatura dada pelos franceses para o espaço remanescente do palco anterior, que ficava atrás do que compunha a quarta parede.

${ }^{10}$ Fundo curvo colocado na parte posterior do palco, geralmente, de cor clara sob o qual são projetadas tonalidades de luz que possibilitam a criação de efeitos de céu ou de infinito, em que também pode-se projetar imagens que complementem a ação dramática, ou como suporte para cenários virtuais ou efeitos especiais 
que até então não era articulado, se tornou uma divisão flexível, porque, quando se passava pela antiga moldura da quarta parede, outro espaço se abria como área de representação. Atualmente, o palco do Bouffes é bastante fundo com dezessete metros de profundidade total.
Para esclarecer o conceito, apresentado anteriormente, é possível dividir o espaço teatral em dois (figura II). O primeiro deles, o círculo próximo à plateia, é muito utilizado nas peças de Brook. Quando um ator se aproxima dois metros em frente do plano do proscênio, sabe-se que existe um enorme ganho em intimidade

Figura 10- Vista do palco com duas profundidades e com as paredes com aspecto de destruído.

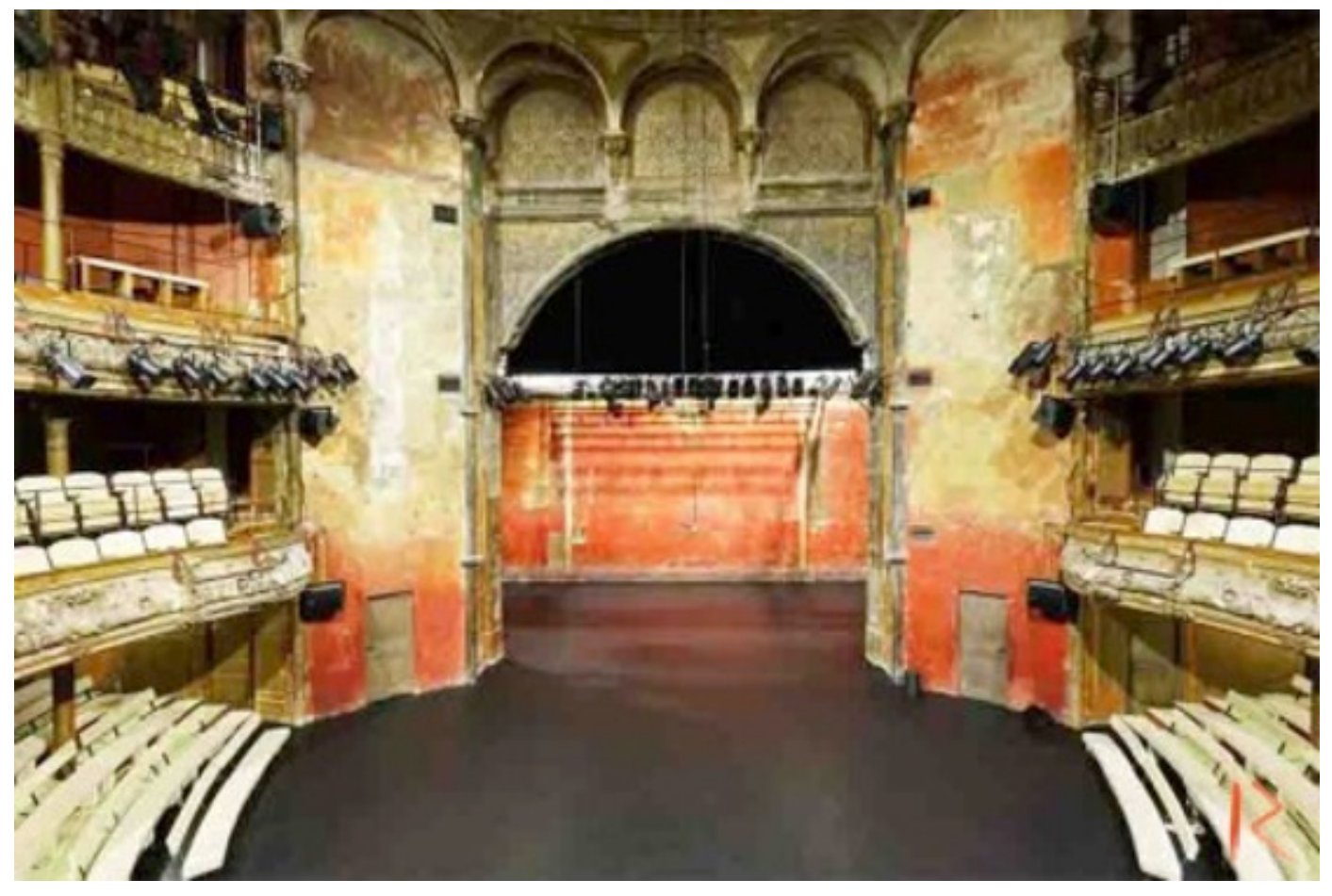

Fonte: Dray (2018). 
com o público. Tal recurso é conscientemente usado pelos atores quando querem puxar o foco. Em seguida, na área da gaiola, existem basicamente duas outras possibilidades: ou se trabalha com o plano do fundo do palco, ou na primeira metade quase no limite da divisória com a boca de cena. O diretor revela que, devido ao enquadramento do próprio espaço, a impressão de distância é muito maior onde quer que seja desenvolvida a cena.

[...] há uma perspectiva curiosa, o que significa que, se você andar para trás no primeiro espaço, vai-se, em termos cinematográficos, de um plano muito grande para um plano geral; e então, quando se volta para além o proscênio, de repente, entra-se em um plano médio: um artifício que usamos muito no Mahabharata, colocando as coisas na parte de trás durante as cenas de batalha, explodindo o ponto de vista em um panorama distante (BROOK apud TODD; LECAT, 2003, p. 27),
Figura II - Planta do Théâtre des Bouffes du Nord com a reforma proposta por Brook. Atenção para os dois espaços de representação possíveis após o ajuste espacial do palco.

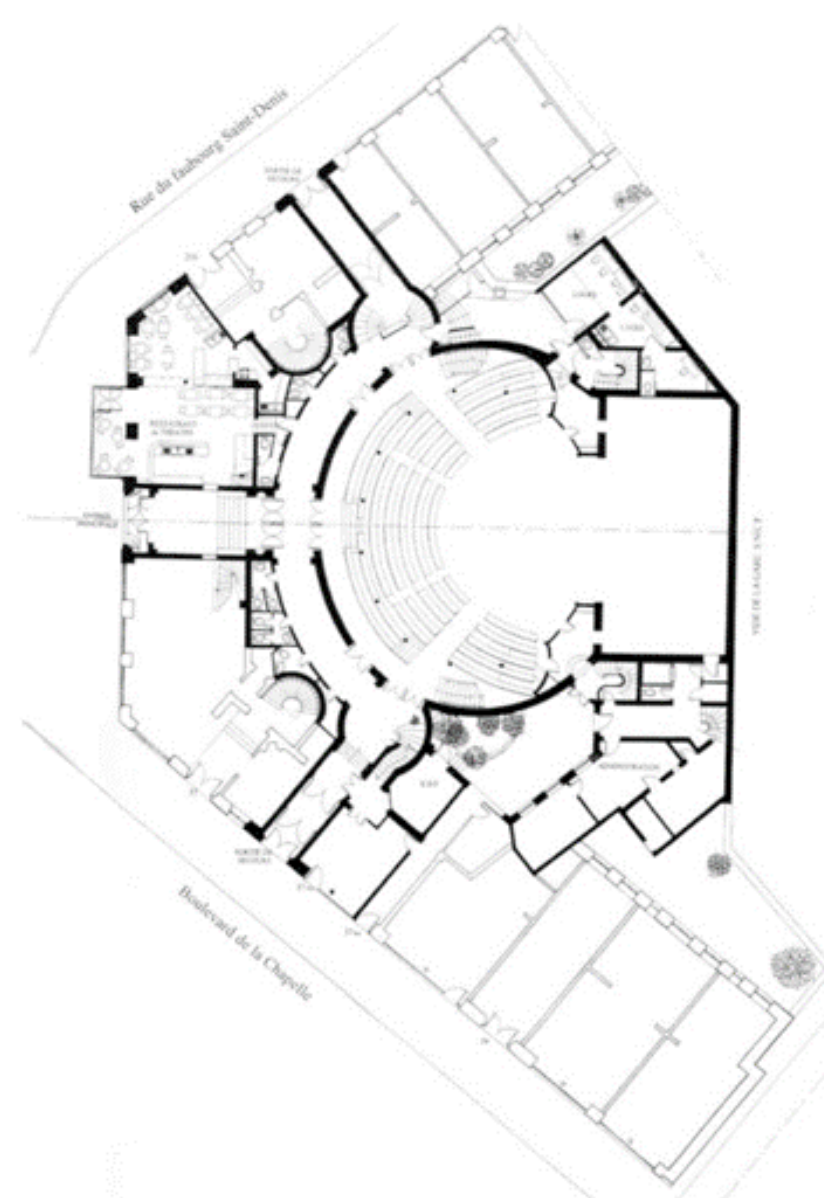

Fonte:Todd; Lecat (2003, p. 19). 
Vale destacar que Brook, a partir do momento em que lançou suas teorias sobre o fazer teatral em 1968 com a publicação de $O$ espaço vazio, procurou imprimir caráter crítico e polêmico às montagens, substituindo a passividade do espectador pela participação do público no espetáculo. Esclarecia que, para que essa alteração no modo de recepção do espetáculo ocorresse, era necessário:

[...] para captar um momento da verdade é preciso que o ator, o diretor, o autor e o cenógrafo, dando o melhor de si, estejam unidos em um esforço comum; ninguém pode conseguir sozinho. No espetáculo não pode haver estéticas diferentes, objetivos conflitantes. Todas as técnicas da arte e do ofício têm que estar a serviço daquilo que o poeta inglês Ted Hughes chama de "negociação" entre o nosso nível comum e o nível oculto do mito. Essa negociação se dá pela junção do que é imutável com a permanente mutabilidade do mundo comum, que é justamente onde se passa cada espetáculo (BROOK, 2005, p. 73).

Partindo-se do pressuposto de que 0 ato teatral se resume a um ator andando e outra pessoa que assiste da plateia, Brook (1999) afirma, em Between two silences, que tudo começa com um silêncio - o momento supremo da comunicação. Para ele esse é o momento em que as pessoas, normalmente divididas entre si por barreiras naturais do ser humano, se encontram em conjunto para compartilhar de um mesmo ponto sobre essa vida extraordinária - "O teatro é sobre a vida" (BROOK, 1999, p. 7). E, nesse curto espaço de tempo, o espectador vai buscar uma situação diferente de vida, de uma maneira mais intensa do que se encontra normalmente no seu dia a dia, para justamente poder refletir sobre as suas questões.

Nos espetáculos em geral, aceita-se que cenários, figurinos e músicas sejam o grande desafio para os cenógrafos e diretores, pois precisam ser constantemente renovados. Segundo Brook (2008), no teatro de entretenimento, geralmente os cenários e figurinos usam velhas fórmulas e métodos, processos banais de solução. Afirma que faz parte desse universo a apreciação de clássicos insossos. Nessa condição, as pessoas vão ao teatro para apreciarem os figurinos ou as mudanças de cenários. Esse tipo de proposta pressupõe que o teatro é essencialmente artificial: tudo é disposto de modo a lembrar-Ihes que estão entrando em um lugar especial, desde a entrada dos atores, que exige um figurino e uma maquilagem, que os disfarcem e mudem as suas identidades. Nessa ocasião "o público também se veste especialmente, de forma a sair do mundo cotidiano, pisando num tapete vermelho, até um lugar privilegiado" (BROOK, 2008, p. 184).

No teatro rústico, frequentemente, os tempos de ensaios são reduzidos e os atores têm necessidade de ganhar vida, de experimentar logo seus cenários, 
figurinos, iluminação, entre outros. A sua plateia não tem dificuldades para compreender a incoerência de sotaques e figurinos, por exemplo, justamente porque o interesse está em seguir a linha da história que é contada, sem querer saber que está se rompendo com algum padrão de estilos.

No entanto, de acordo com o ponto de vista de Brook, para colocar os espectadores em contato com o tipo de teatro que pretende alcançar - do universo misterioso e fascinante, ou seja, com o Teatro Sagrado - existem dois métodos. O primeiro deles consiste na busca pela beleza. Segundo ele, a maioria do teatro oriental se baseia nessa metodologia. Quer extrair o máximo de beleza de cada elemento cênico para fascinar a imaginação da plateia - o kabuki no Japão ou o kathakali na Índia seriam bons exemplos dessa vertente. Ali há uma busca pela perfeição nos menores detalhes: desde a maquiagem até os ínfimos adereços, tudo tem uma lógica que supera a simples solução estética. Também os cenários e os figurinos são desenhados de modo a refletir outro nível de existência. E, por meio dessa pureza, tenta-se atingir o sagrado.

Por sua vez, o outro método parte do princípio de que "o ator possui um extraordinário potencial para criar vínculos entre a sua imaginação e a do público, fazendo com que um objeto banal possa transformarse num objeto mágico" (BROOK, 2005, p. 38). Para isso, é fundamental que se tenha à disposição exímios mestres no ofício da interpretação teatral, ou seja, atores e atrizes de alto nível. Com uma grande atriz, exemplifica, é possível fazer com que uma garrafa de plástico que carrega nos braços de um modo especial se transforme em uma linda criança (BROOK, 2005). Ou seja, somente com alguém qualificado para desenvolver essa atividade se consegue realizar

[...] esta alquimia, na qual uma parte do cérebro vê a garrafa e a outra parte, sem contradição, sem tensão, mas com alegria, vê o bebê, a mãe segurando o filho e a natureza sagrada de sua relação. Esta alquimia só é possível se o objeto for tão neutro e comum que possa refletir a imagem que $\circ$ ator the atribui. Poderíamos chamá-lo de 'objeto vazio' (BROOK, 2005, p. 39).

Revela que, quando um diretor é atraído por alguma questão, é sempre algo a mais do que uma simples decisão comum. É uma sensação: é tão impossível de definir como um palpite ou um gosto. Ele deve ter uma vaga ideia de onde pretende chegar, mas é importante ter clareza do que pretende alcançar (BROOK, 2005).

Para se ter um bom resultado é importante proceder desse modo, além de estar aberto para a colaboração dos atores e da equipe de cenografia e figurino. Se as relações com os demais membros da equipe forem boas, todos seguirão voluntariamente com o processo. 
Mas o processo também pode ser iniciado pelo forte palpite dos designers. Porém essa situação só pode ser bem-sucedida se a intuição dos projetistas estiver relacionada com a qualidade do trabalho e não com a vontade de realizar o projeto para o seu benefício próprio. Se for dessa maneira, haverá um respeito de todos da equipe e o diretor será mais do que grato pelas indicações (BROOK, 2005).

Descreve que, cada vez que começava uma nova produção, era obrigado a reabrir esta questão como se fosse pela primeira vez.

O que os atores poderiam usar? Existiria uma época subentendida na ação? O que é uma época? Qual é a sua realidade? Seriam reais as informações que os documentos nos fornecem? Ou seria mais real um voo da imaginação e da inspiração? Qual é o propósito dramático? O que necessita de vestimenta? $\bigcirc$ que precisa ser definido? $O$ que exige ○ ator, fisicamente? $\bigcirc$ que pede o olho do espectador? Deve esta exigência do espectador ser satisfeita harmoniosamente ou contrariada dramaticamente? Que coisas podem ser valorizadas com a cor e a textura? O que elas podem encobrir? (BROOK, 2005, p. 147).

Para o diretor inglês, o primeiro ensaio era sempre, em certa medida, como a ação de um cego guiando outro. No fatídico primeiro dia, o diretor podia fazer um discurso formal, explicando as ideias básicas por trás do trabalho a decorrer. Ou então mostrar algumas pesquisas que havia feito previamente, mostrar esboços de figurinos, ou exibir imagens de livros, ou fotografias, ou ainda sugerir que todos lessem a peça. Poderia, também, insinuar uma brincadeira coletiva, marchar em volta do teatro ou sacar ideias para um cenário.

Todavia, o resultado seria sempre igual: ninguém estaria em condições de absorver o que era dito nesse primeiro momento. Em A porta aberta, Brook expôs que, antes do primeiro dia de ensaio, fazia esboços do cenário e das marcações de cena como exercício, porém tinha certeza que isso se tratava de preparação para o seu processo de direção. Jamais pedia aos atores que utilizassem aquilo que estava esboçado pois, desse modo, estaria cerceando o processo de encenação. "É preciso fazer a preparação para jogá-la fora, construir para poder demolir [...]" (BROOK, 2005, p. 2I).

Em Ponto de Mudança, desvenda o seu processo de criação, de montagem de um espetáculo. Afirma que sempre que começava a trabalhar em uma nova peça, partia de sua intuição. Não tinha especificamente uma forma, era como se fosse algo etéreo e indefinível "como um perfume, uma cor, uma sombra" (BROOK, 1994, p. 19). Se convencia de que a peça precisava ser realizada naquele momento, pois sem essa convicção acredita que não seria possível realizá-la. Assim não há 
uma técnica ou uma estrutura própria para o início, pois partia dessa sensação amorfa e informe para se preparar para o processo.

Brook define que sua preparação é resultante da perseguição dessa ideia inicial. Em seguida, evidencia que:

Começo desenhando o cenário, rasgando-o, desenhando, rasgando, trabalhando-o. Que tipo de figurino? Que espécie de cores? É a busca de uma linguagem para tornar aquela intuição mais concreta. Até que geralmente surge a forma, uma forma que precisa ser modificada e posta à prova, mas de qualquer modo é uma forma que está emergindo. Não uma forma fechada, porque é apenas o cenário e digo "apenas o cenário" porque o cenário é somente a base, a plataforma. Então começa o trabalho com os atores (BROOK, 1994, p. 1920).

Para ele, os ensaios precisam criar um ambiente no qual os atores sintam-se livres para experimentar tudo o que puderem trazer para a peça. Por isso nas primeiras fases do ensaio tudo é permitido e o diretor não impõe nada aos seus atores. Devido a sua extensa experiência, relata que já nas últimas fases de ensaio, o trabalho sempre começa a iluminar "uma área obscura, que é a vida subterrânea da peça; e quando essa área subterrânea é iluminada pelo ator, o diretor fica sem condições de ver a diferença entre as ideias do ator e a peça em si” (BROOK, 1994, p. 2I).

Conforme a explicação supramencionada, somente nos últimos estágios dos ensaios começava a desempenhar - que, usualmente, é reconhecido como o papel do diretor. Desse modo, eliminava tudo o que era estranho à essência da montagem, ou seja, tudo que pertencia unicamente ao ator, preservando sempre conexão intuitiva do ator com a peça. Tratava-se de um momento importante pois era necessário tanto pressionar, quanto encorajar o ator a descartar tudo o que era supérfluo, de modo a editar e condensar as principais ideias. Compreendia que a peça não era a somatória de ideias impostas a ela. Para se atingir uma forma orgânica, o espetáculo precisava ser iluminado e trabalhado, pois a iluminação conferia a ele essa forma harmônica.

Os elementos que sempre deram certo durante o processo de ensaio passavam por uma experiência empírica, uma vez que, sob a sua visão, a estética é resultado da prática:

[...] a altura de uma cadeira, a textura de um figurino, o brilho da luz, a qualidade da emoção são importantes o tempo todo. [...] Uma cadeira é deslocada para frente ou para trás do palco porque é melhor assim. Duas colunas não ficam bem - mas colocando uma terceira, dá certo (BROOK, 2008, p. I40). 
O palco seria o reflexo da vida, mas completamente estabelecido com bases no processo de observação e elaboração de julgamento de certos valores. $O$ espetáculo, por sua vez, seria resultado de três tipos de relacionamentos: antes mesmo de se iniciarem os ensaios, o relacionamento entre diretor/assunto/ figurinista/cenógrafo; durante os ensaios, a relação entre ator/assunto/diretor; e, nas apresentações, ator/ assunto/plateia. Os cenários e figurinos poderiam evoluir durante os ensaios, ao mesmo tempo em que se desenvolvia o restante do espetáculo.

Brook (1994) entendia que a concepção da peça deveria ser dividida em duas etapas: a primeira, a preparação; e, a segunda, o nascimento. Em relação ao processo de preparação dizia que poderia durar apenas cinco minutos, como numa improvisação, ou vários anos, como em outras formas de teatro. Mas, novamente, ressalta que preparar não é fixar um formato para as cenas. A conformação exata do espetáculo só ocorre no momento crucial, quando é exposto ao público. Geralmente, quando um ator, ou o próprio diretor, descobria uma solução brilhante para uma cena, era impossível dizer se o ingrediente vital surgiu de sua criatividade ou se já estava o tempo todo ali, à espera de ser descoberto.

Relata ainda que criou uma tradição no processo de concepção de seus espetáculos, da qual fazia parte os ajustes de elementos cênicos. Quando chegavam acerca de dois terços do período de ensaios, apresentavam o trabalho tal como estava: inacabado, usualmente para uma plateia de crianças em uma escola. Na maioria das vezes, as crianças não conheciam a peça e não eram informadas do que se tratava. $O$ grupo ia sem objetos de cena e figurinos, não utilizavam qualquer recurso para a encenação, apenas improvisavam com objetos que estavam disponíveis no espaço vazio da sala de aula para saber se estavam tomando a direção certa para a encenação.

Dizia que, quando surgia algo verdadeiro nos ensaios, os cenários, figurinos, e iluminação se encaixam naturalmente. Então só nesse momento era possível ter clareza sobre o que precisava ser realçado, por uma música ou por uma cor. Para Brook, se os elementos visuais do espetáculo fossem concebidos muito cedo ou, se por exemplo, o cenógrafo já tivesse cristalizado suas ideias antes do primeiro ensaio, as formas seriam impostas e poderiam conter o processo intuitivo dos atores, em um momento em que era importante que trouxessem as imagens mais profundas que possuíam. Portanto, o ato necessário de se estabelecer marcas e estruturas do espetáculo deveria ocorrer o mais tarde possível. De preferência somente durante a primeira apresentação. 
O processo é circular. No início temos uma realidade sem forma. No final, quando o círculo se fecha, essa mesma realidade pode ressurgir de repente - assimilada, canalizada e digerida - dentro do círculo de participantes que estão em comunhão, sumariamente divididos em atores e espectadores. Só nesse momento a realidade se torna viva, concreta, e o verdadeiro significado da peça vem à tona (BROOK, 1994, p. 38).

Em O espaço vazio, Brook (2008) afirmou que, com frequência, o processo de concepção dos cenários acabava se tornando a geometria do espetáculo definitivo. E continuou dizendo que um cenário em desacordo com a proposta cênica, muitas vezes, tinha o poder de impossibilitar que cenas sejam executadas, restringindo, assim, as possibilidades dos atores. De acordo com suas observações, no processo adequado, o cenógrafo evoluía à medida que o diretor avançava com a encenação e, se fosse necessário, retrocedia, alterava, reformulava conforme, gradualmente, fosse se delineando a concepção do conjunto. Por experiência, uma vez que, no início de sua carreira projetou diversas vezes os cenários e figurinos de suas próprias peças, dizia que os diretores que tinham essa atitude de nunca acreditarem terem chegado a um resultado satisfatório.

Assim como o processo de direção, projetar os elementos visuais é um processo longo, de mudanças.
A vantagem visível dessa situação é que a evolução destes elementos, como por exemplo, a seleção de formas e cores, ocorre paralelamente e ao mesmo tempo que o desenvolvimento da compreensão da peça em sua extensão. À medida que trabalha no cenário, pode-se encontrar a resposta para cena que escapava da sua compreensão por várias semanas. Do mesmo modo, conforme se está trabalhando sobre uma difícil estrutura de cena, de repente, ao captar seu significado em termos de ação cênica, pode-se resolver uma sucessão de cores, ou dar forma a um cenário que parecia incompleto.

Brook (1994) explica que alguns profissionais acreditavam que, ao entregarem seus estudos de cenários e figurinos elaborados separadamente do grupo, já haviam realizado o mais importante de seu trabalho, pois já exerceram a sua parte criativa. Levavam em consideração que, uma vez o projeto realizado, o trabalho estava concluído. No entanto, para Brook (1994), era mais importante um desenho incompleto, um desenho que tivesse clareza sem ter rigidez, e estar ao lado de um profissional que considerasse as constantes mudanças em relação ao que os atores estavam propondo em cena, do que um trabalho realizado separadamente. O que mais importava era a compreensão mútua do desenvolvimento do ritmo de trabalho. Esse ajuste fino entre os tempos era fundamental para o diretor. 
Apesar de ter trabalhando sempre com designers experientes, às vezes se encontrou em algumas armadilhas sugeridas pelo processo, como por exemplo, quando o cenógrafo era rápido demais e chegava a um ótimo resultado, impondo, de certo modo, seu resultado ao trabalho de direção.

De modo que me vi forçado a aceitar ou recusar formas antes de ter sentido que formas pareciam ser imanentes no texto. Quando aceitava a forma errada, por não ter achado nenhuma razão lógica para me opor à convicção do cenógrafo, trancavame numa armadilha da qual a direção não conseguia mais evoluir e, em consequência, produzi um péssimo resultado (BROOK, 1994, p. 144).

Para Brook (1994), o momento da verdade era a estreia da apresentação. De acordo com seu ponto de vista, era bem diferente observar um projeto de cenário estático, assinado por Picasso por exemplo, de um cenário que funcionava em seus espetáculos. Fazia toda diferença trabalhar com designers que, na realidade, estavam mais interessados em colocar seu projeto ou sua imagem em evidência; daqueles que se preocupavam com cada cena e com uma solução que jamais se sobrepusesse ao espetáculo. Ao ser questionado sobre nomes de projetistas que se destacaram como preferenciais em seus processos de trabalho, explicita:
[...] por exemplo, os designers com quem trabalho, principalmente Chloé Obolensky, com quem eu tenho trabalhado por vários anos, e, antes disso Sally Jacobs, são ambas designers que irão sentar-se em cada ensaio e que vão deixar o projeto evoluir até o último momento possível (BROOK, 1999, p. 108).

O bom designer, seguindo suas convicções, tinha todas as possibilidades à sua frente e estava trabalhando, observando o espetáculo e, principalmente, conversando sobre as necessidades de perto, com o diretor. E, nesse processo de troca, era fundamental que se tivesse um ponto de vista completamente distinto um do outro, para que o embate de ideias enriquecesse o material a ser produzido. Também era importante, e um pouco mais sutil de ser observado, que a sintonia entre os tempos de trabalho do cenógrafo/figurinista e do diretor se desenvolvessem num mesmo ritmo. Segundo Brook (1999), em seus processos, era necessário que houvesse observação, pesquisa e investigação até que as propostas evoluíssem e fossem finalmente concluídas.

Retomando uma questão colocada logo de início, para o encenador não eram os trajes de cena, o cenário, a iluminação e o palco convencional que estabeleciam a experiência cênica. $O$ teatro não tinha por base o palco, o cenário, a luz, a música e as poltronas. Para se fazer teatro somente uma coisa era necessária: o elemento 
humano. $O$ que não quer dizer que o restante, supraapontado, não tenha importância; de acordo com seu ponto de vista, somente não era o principal. Brook (2005, p. 12) insistia:

Já afirmei, certa vez, que o teatro começa quando duas pessoas se encontram. Se uma pessoa fica de pé

e a outra a observa, já é um começo. Para haver um desenvolvimento é necessária uma terceira pessoa, a fim de que haja um confronto. E então a vida se instaura, podendo chegar muito longe - mas aqueles três elementos são essenciais.

O autor se refere, portanto, à utilização do espaço vazio, dizendo que era inevitável que nele houvesse uma ausência de cenário. Essa acabava sendo sempre uma opção mais interessante: a exploração da imaginação dos espectadores. A ausência de cenário era um prérequisito para a atividade da imaginação.

Ao colocar somente duas pessoas lado a lado, num espaço vazio, a atenção do público se estenderia aos menores detalhes da encenação. No teatro um ator por exemplo com roupas normais, poderia sugerir que estava representando o Papa porque estava usando um gorro branco de esquiador. Bastava uma simples palavra para que o Vaticano estivesse no palco.

No teatro a imaginação preenche o vazio devido a convenção que é estabelecida entre o público e os atores. $O$ vazio permite que a imaginação preencha os buracos de maneira paradoxal, quanto menos é oferecido e mais lacunas são ofertadas, melhor para a imaginação, "pois é um músculo que gosta de se exercitar em jogos.” (BROOK, 2005, p. 23),

A participação da plateia consiste em ser cúmplice da ação e aceitar as convenções que são estabelecidas. A imaginação faz parte desse jogo desde que o ator não esteja "em parte alguma”. Se, por acaso, houver qualquer elemento ilustrativo-simbólico, a verossimilhança, imediatamente, intervém e o jogo imaginativo fica preso nas fronteiras lógicas dos elementos físicos da encenação. Todas as convenções são cabíveis desde que estejam livres de formas rígidas.

Brook (2005) explicita que, quando a ênfase está nas relações humanas, há uma liberação da encenação em relação à unidade de lugar e de tempo, pois a atenção está voltada para interação entre os atores no palco. Em um palco livre, o cenário é criado de modo dinâmico e totalmente aberto mediante a interação das personagens. Só que, para que todas estas questões possam ocorrer, é fundamental que haja uma diferença entre o teatro e o não teatro, entre a vida diária e a vida teatral, que é estabelecida por uma intensificação de energia, que é o que pretende o vínculo da ação cênica com o espectador.

Sobre a concepção da indumentária dos espetáculos, ressalta que era bastante frequente que o traje de cena 
errado estragasse a representação dos atores. Para Brook (1994), o ator sempre deveria ser consultado; porém, nunca antes de começarem os ensaios. Fazer essa consulta no momento errado seria o mesmo que solicitar ao diretor para que tomasse uma decisão antes de estar preparado. Antes de experimentar o papel, o ator somente pode passar uma impressão teórica que teria sobre seu personagem.

Se ocorrer de o figurinista desenhar um belo traje de cena e o ator aceitar, precocemente, e com entusiasmo utiliza-ló mesmo antes do processo de ensaios, se poderia descobrir, algum tempo mais tarde, que o resultado não era condizente com o que ele estava tentando expressar. Não deveria ser reduzida somente à questão de ver o que o ator precisaria usar, mas também, de se relacionar com todos os elementos visuais do espetáculo.

Segundo o encenador é fundamental que o figurinista entenda que os trajes de cena são ferramentas fundamentais para os atores. No processo de encenação o ator sempre começa com algo muito pequeno e íntimo e, de certa forma, cria uma resistência sobre o que vem proposto pelos figurinistas, pois ele "também tem um palpite sem forma” (BROOK, 1999, p. II5) sobre as características físicas da personagem que está deixando crescer em si à medida que entra em contato com essa figura. Gradualmente, ele percebe que tem que se comunicar com o figurinista e partilhar o que está fazendo, dividir o que, secretamente, encontrou em seu íntimo e que deve ser transmitido para o exterior.

- traje de cena é uma importante ferramenta de leitura do público sobre o que está se passando com o desenvolvimento do trabalho do ator. Se o figurinista estiver em sintonia com o ator, quando ele tira suas roupas de ensaio e coloca o figurino, vai se sentir muito melhor. Porém, se esse vínculo não for estabelecido, instaura-se o bloqueio. E reaparece o velho mito de que "era melhor no ensaio do que era no palco" (BROOK, 1999, p. I16) que, na opinião de Brook (1999), nunca deve ser a verdade.

O ideal é que exista um entendimento e um bom relacionamento no desejo de ambos. Para o diretor é importante que a aparência do traje leve em consideração as necessidades do ator em cena. Caso ele necessite de liberdade, por exemplo, jamais se deve agir destrutivamente, impondo a ele uma silhueta que Ihe restrinja a movimentação. Em situações como essa alguém tem que ceder e, em sua opinião, o ator tem sempre que ser ouvido. É importante que ele se sinta confiante e livre em suas roupas (BROOK, 1999).

Sobre a representação que utiliza trajes locais, ou mesmo o que usualmente se denomina de trajes de época, Brook (2000) é enfático: a não ser que se busque realmente a peça original, tanto do período como da 
localidade, sempre se tratará de uma cópia baseada em estudos. Sempre há uma série de concessões: ou o material é somente aproximativo, pois os detalhes de corte e material são adaptados ou, quando próximo do original, o ator descobre que não consegue se mover nesse traje com a mesma desenvoltura que os nativos, por exemplo. Tampouco defende que a solução de tal problema seja a utilização de roupas do dia a dia: em seu ponto de vista isso seria tão inadequado quanto se estabelecer uniformes para um espetáculo.

Brook (2000) diz ter aprendido que é importante analisar qualquer proposta de elementos cênicos dentro do contexto do espetáculo em si. Cita, como exemplo, uma experiência que teve enquanto estava encenando Trabalhos de Amores Perdidos, em Stratford-upon-Avon, em 1946, com a Royal Shakespeare Company. Três dias antes de sua estreia se deparou com a prova de roupas de outro espetáculo - A Tempestade, que também entraria em cartaz no mesmo dia que o seu. Observou os exuberantes trajes de cena elisabetanos - com veludos, penas e golas - expostos pelos atores ao diretor e ao figurinista. Pensou que sua proposta de trajes, baseada na obra do pintor rococó francês Antoine Watteau (figura 12), tinha certa elegância pela forma com que o tecido se movimentava com os gestos dos atores, mas era extremamente simples comparado com toda a exuberância exibida.
Figura 12 - Figurino baseado na obra do pintor rococó francês Antoine Watteau do espetáculo Trabalho de Amores Perdidos de Peter Brook.

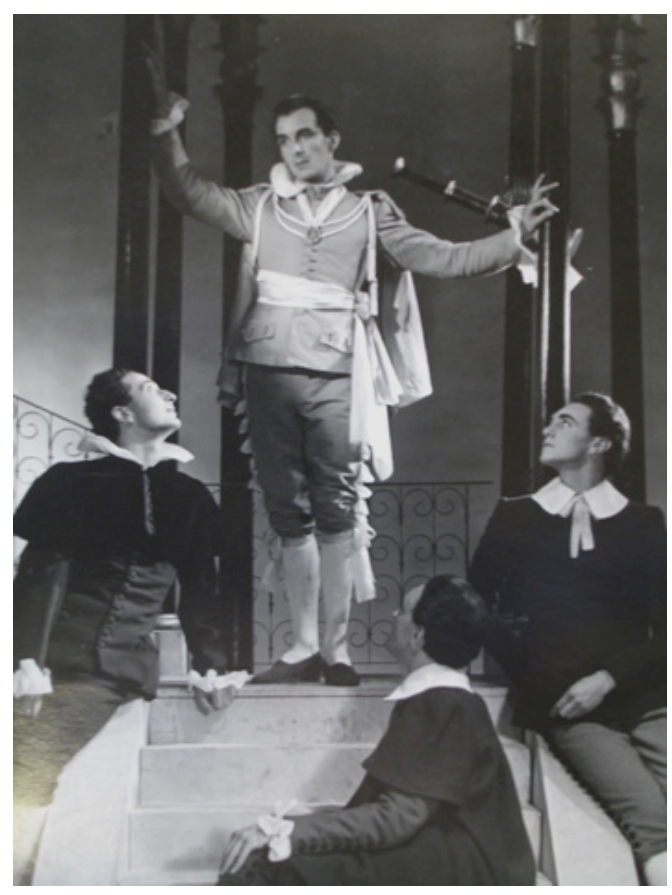

Fonte: Morris (2013). 
Contudo, durante a apresentação desta montagem de A Tempestade, tudo o que podia dar errado aconteceu: cenários caíram, as mudanças de cena não funcionaram e Brook se surpreendeu ao perceber que aqueles esplêndidos trajes exibidos anteriormente pareciam estar em excesso na cena, tornando-se cada vez mais inadequados ao espetáculo.

Desse modo aprendeu uma lição: nada relacionado com projeto no teatro é inseparável do fato de que o teatro não é uma imagem estática. É uma peça em movimento e, desde o início, cada movimento, imagem, som e palavra tem seu efeito sobre o público,

[...] trazendo o público mais perto dos personagens, mais em certas situações humanas, trazendo o seu interesse acima, em seguida, baixá-lo para um momento. É encaixado nesta estrutura rítmica que cada elemento tem o seu lugar (BROOK, 1999, p. 90).

Ao ser questionado sobre o processo de simplificação em seu estilo de trabalho, Brook (1999) explicou que quando começou a trabalhar não tinha nenhuma razão para questionar o que eram os teatros naquela época: edifícios com um palco, um público sentado na escuridão, um porta-retratos e, em seguida, uma área atrás. Dentro dessa lógica, de início, se interessava pelo design dos elementos de cena, pois acreditava que o que acontecia dentro da moldura deveria ser feito do modo mais fascinante possível.

Desde o início tinha a intuição que os atores deveriam trazer vitalidade por meio de seus movimentos físicos e da forma como se relacionavam entre si. Deveriam se valer do frescor e da natureza não convencional de sua atuação para poderem conquistar a audiência. De acordo com esse princípio, antes do questionamento das convenções teatrais, eram os elementos por trás do porta-retratos que o estimulavam mais, tais como: as luzes, as cores e os movimentos de palco. Porém logo começou a perceber que a imagem que se estava produzindo não poderia ser muito completa pois, se fosse saturada, a imaginação do espectador não fluiria. Começou a perceber que tudo dependia de encontrar uma base física de trabalho, um esqueleto estrutural da peça em particular.

Era importante, então, identificar se esse esqueleto estava correto para determinada produção pois caso optasse por algo que não se encaixasse com o que era pedido pelo espetáculo, tudo estaria perdido. Gradualmente, com sua vivência ao longo dos anos, os conteúdos humanos de uma peça se tornaram mais centrais em seu trabalho. Até o instante em que se tornou absolutamente necessário explorar isso. Tinha chegado a hora de colocar em discussão todas as questões tradicionais do teatro convencional: fazer peças a céu aberto, experimentar novas possibilidades. 
Partiu para uma nova experiência: a de verificar o que acontecia quando se trabalhava com algo infinitamente mais básico: dedicar-se apenas ao ser humano e nada mais. Por meio de experimentos, improvisações, pequenas performances, percebeu que o elemento central no teatro era justamente a questão humana: que poderia mexer com ela sem qualquer artifício. Assim seu ponto de partida havia se invertido, não era mais uma imagem que deveria ser preenchida com empolgação mas contar a história de um ser humano a outros que estavam assistindo. E a partir dessa lógica, identificar quais eram os elementos fundamentalmente necessários para se poder contar a história.

Em relação aos trajes de cena, é importante colocar que o figurino é o responsável por situar o público onde e quando a peça se passa. A partir da análise de seus espetáculos, ficou evidente uma adequação em relação às solicitações da mensagem a ser transmitida. Quando se tratava de um espetáculo no qual havia a necessidade de se criar uma atmosfera mais histórica, existia toda uma pesquisa relacionada com o momento histórico abordado, ou com a cultura na qual se ambientava.

Entretanto sempre existia um processo de síntese da impressão que se tem com as referências históricoculturais. Nunca era a completa reprodução de trajes existentes, mas uma releitura deles. Quando eram abordados assuntos de ordem mais universais, existia uma predileção por roupas que não imprimam a ideia de temporalidade, mas que passassem uma ideia de atemporalidade. As cores sempre retratavam significativamente as características das personagens que as vestiam.

Com base nestas colocações é possível estabelecer algumas relações de Brook com a proposta simbolista do início do século $X X$. Assim como no simbolismo, há na proposta do diretor inglês uma intensa crítica com a relação à caixa preta e à quarta parede como forma de representação cênica. Outra aproximação entre as pesquisas é a investigação sobre a comunicação, evidenciando a palavra como forma de estabelecer a interlocução necessária para o desenvolvimento do espetáculo. Bem como uma busca em estimular a imaginação e emoções do espectador por meio do que não está visível.

Em relação às propostas de Appia, em primeira instância percebe-se, com o amadurecimento dos princípios de Brook, a eliminação de todos os elementos que não trazem significado para o fazer teatral. Ambos preferem que o palco esteja livre para que, assim seja possível trabalhar com a proposta de exercício de imaginação dos espectadores. Interferem no espaço dos espectadores e na sala de espetáculos de modo a permitir que haja uma maior sintonia com a ação cênica.

Mesmo que Brook trabalhe mais com o plano horizontal 
do que os demais em suas propostas cenográficas, é evidente que a movimentação dos atores em cena é considerada na composição do espetáculo para que seja possível atingir o sagrado. Apesar de ainda não ter sido aprofundada essa questão neste capítulo, há ainda uma investigação com a iluminação cênica de modo que esta interfere diretamente no fazer teatral, criando a ambientação necessária para ressaltar a mensagem pretendida como nas propostas do cenógrafo suíço.

Ao se estabelecer uma relação com os ideais de Craig, fica evidente que Brook também não privilegia nenhum dos elementos do jogo cênico pois trata todos com a mesma importância. Afirmava que Craig estava em busca da perfeição e, como não via a possibilidade de encontrá-la no teatro comercial, restringiu a sua busca nessa pesquisa denominada Drama for Fools, uma peça de teatro escrita por ele próprio com 365 cenas de marionetes, para a qual desenhou todos os cenários e os trajes em cores primárias.

Brook admirava a invejável defesa que Craig fazia de seus ideais, podendo alguns pontos serem observados como elementos comuns entre os dois. Dentre os quais, destacam-se: o desejo de trabalhar com o palco livre de grandes estruturas e cenários; a ideia de tratar o teatro com algum caráter sagrado, mesmo que os objetivos de ambos fossem completamente distintos nessa finalidade; e, finalmente, a luta e busca pelos seus ideais.

\subsection{A principal experiência realista simbólica de Brook - Titus Andronicus (1955)}

Conforme dito anteriormente, foi em 1955 que Brook se consagrou entre os mais novos diretores ingleses com a montagem de Titus Andronicus de William Shakespeare, protagonizada por Sir Laurence Olivier. Para compreender o processo de elaboração dos elementos visuais se torna relevante a trajetória do pensamento do diretor, pois o mesmo relata que nesse espetáculo ele foi o responsável pela cenografia da montagem.

Quando Brook trabalhou, pela primeira vez, na Royal Shakespeare Company em Stratford-upon-Avon, dizia que eram sempre os mesmos espetáculos que se repetiam a cada temporada. Em sua primeira produção com o grupo inglês, Trabalhos de amor perdido de Shakespeare, comentou que havia sido influenciado pelo contexto pós II Guerra Mundial. Um momento em que se lutava contra uma espécie de paralisia e austeridade social na Europa. Mencionou que, naquela época, para as montagens se almejava charme e elegância e que era bastante complicado encontrar seus objetivos com os figurinos elisabetanos, bastante convencionais naquele momento.

Logo a seguir, justamente na segunda montagem com o grupo, ganhou destaque nacional entre os encenadores da época. Em 1955, Glen Byam Shaw, diretor da 
companhia inglesa estava montando uma temporada com Titus Andronicus, na Royal Shakespeare Company com Sir Laurence Olivier, como Tito, e sua esposa Vivien Leigh, como Lavinia. Shaw perguntou se Brook estava interessado em realizar essa montagem do espetáculo.

Trata-se de um texto bastante controverso de Shakespeare. Bloom (200I), professor e crítico literário norte-americano, afirma, por exemplo, que o texto revela algo de arcaico no sentido negativo do termo. De acordo com suas colocações essa é uma peça shakespeariana que deveria ter sido esquecida ou só deveria ser desempenhada como uma paródia, uma vez que o público elisabetano do século $X V I$ era tão sedento de sangue quanto as massas atuais que assistem a sangrentos filmes produzidos por Hollywood.

Brook (1994) explica que, quando saíram as críticas ao espetáculo a maioria das observações diziam que a companhia havia conseguido salvar aquela abominável peça de Shakespeare. Relatavam que o espetáculo conseguiu dar um jeito a essa "peça ridícula e inviável" (BROOK, 1994, p. 2I), sendo muito superior ao texto original. Para espanto do grupo, durante os ensaios, não haviam percebido que o espetáculo fosse tão ruim quanto estavam afirmando os críticos.

Em Ponto de Mudança (1994), o diretor inglês enfatizou que todo o trabalho de montagem da peça consistiu em desvendar as sugestões e os meandros secretos do texto, trazendo à luz os elementos que, na maioria das vezes, não foram explorados em outras montagens. Sugeriu que a peça começou a se revelar a partir do momento em que se distanciaram dos momentos melodramáticos do texto. Para ele tudo estava ligado a uma corrente obscura, em que os horrores fluem em um belo ritual bárbaro.

Durante o processo de montagem enfatizavam-se as raízes saxônicas que permaneciam nos ingleses. Sendo assim, "o gosto romano por esportes sangrentos, por gladiadores, luta com leões, não podia ter destruído sua verdadeira trágica herança grega: Electra, Medeia e todos os terríveis atos de catarse que sublimavam o terror" (BROOK, 2016, p. 49). Exploraram as possibilidades dos rituais ferozes presentes nas mitologias islandesas e saxônicas e, ao atingir tais objetivos, puderam se conectar com essas tradições fazendo emergir na plateia uma nova beleza bárbara.

Em seus depoimentos Brook afirma que Laurence Olivier aprofundou-se tanto no papel do vingativo Tito que, em pouco tempo, conseguiu revelar uma personagem de carne e osso. Porém foi Vivien Leigh que trouxe uma qualidade de beleza e poesia para as desgraças que ocorrem com Lavínia, que foi violentada e teve suas mãos decepadas. Trata-se de uma cena bastante marcante que permaneceu na memória dos espectadores e foi construída em conjunto com o figurinista Desmond Heeley", que desenhou, nos 
trajes da atriz, uma fita vermelha que caia dos dedos até o chão, transformando a cena em um momento perturbador de beleza.

A escolha das cores nesse traje não foi acidental, conforme pode-se observar na figura 13. De acordo com Kandinsky (1996) em Do espiritual na arte e na pintura em particular, a escolha do azul para a túnica reforçava o desejo de pureza e a necessidade de contato com o divino, avigorando a construção da atriz e agregando o significado de paz e calma consigo. As mangas, com a cor vermelha, estavam nitidamente associadas à simbologia do sangue derramado pela personagem, porém também poderiam ser compreendidas como símbolo de agitamento, transbordamento de vida e efervescência.

Figura 13 - Proposta de concepção e traje de cena de Lavínia em Titus Andronicus (1955) direção de Peter Brook.

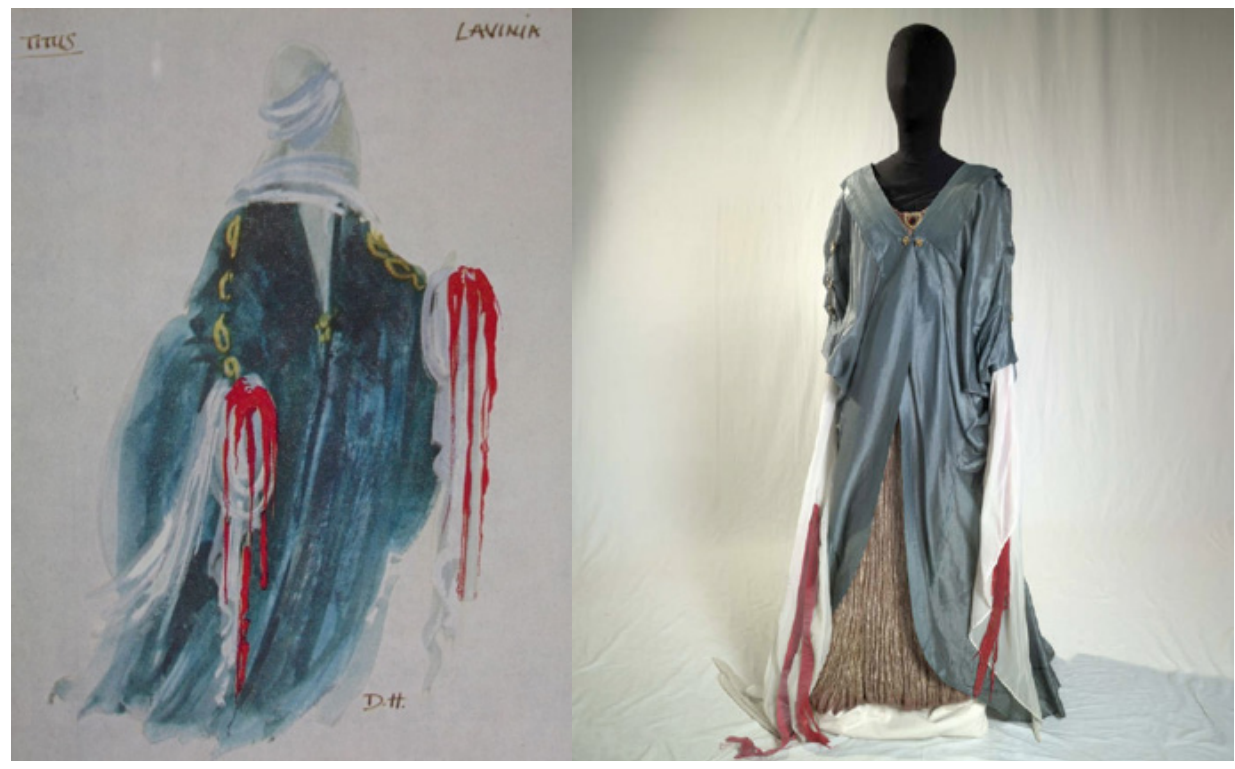

Fonte:Arquivos do RSC encontrados nos acervos do V\&A Museum.

"Desmond Heeley começou sua carreira, aos dezesseis anos, na Grã-Bretanha

como aprendiz no departamento de adereços do Shakespeare Memorial

Theatre em Stratford-upon-Avon, onde seu dom de criar bons trajes de cena

foi notado por Peter Brook que, em 1955, o contratou para desenvolver o

projeto de figurinos para a famosa produção de Titus Andronicus 
O protagonista Tito usava um traje que fazia referência aos trajes de imperadores romanos. Era composto por um tecido brilhante que se assemelhava a um courino na cor vermelha (figura 14). A cor desse traje também não era casual: evocava a força, impetuosidade, energia, decisão, presentes nas características que Sir Olivier trouxe à personagem. $O$ adereço de cabeça - uma coroa de louros -, reiterava a referência aos heróis romanos propostos para os trajes de cena.

Figura 14 - Cena de Lavínia com Titus e traje de Titus proposto por Heeley para o espetáculo Titus Andronicus (1955) direção de Peter Brook.

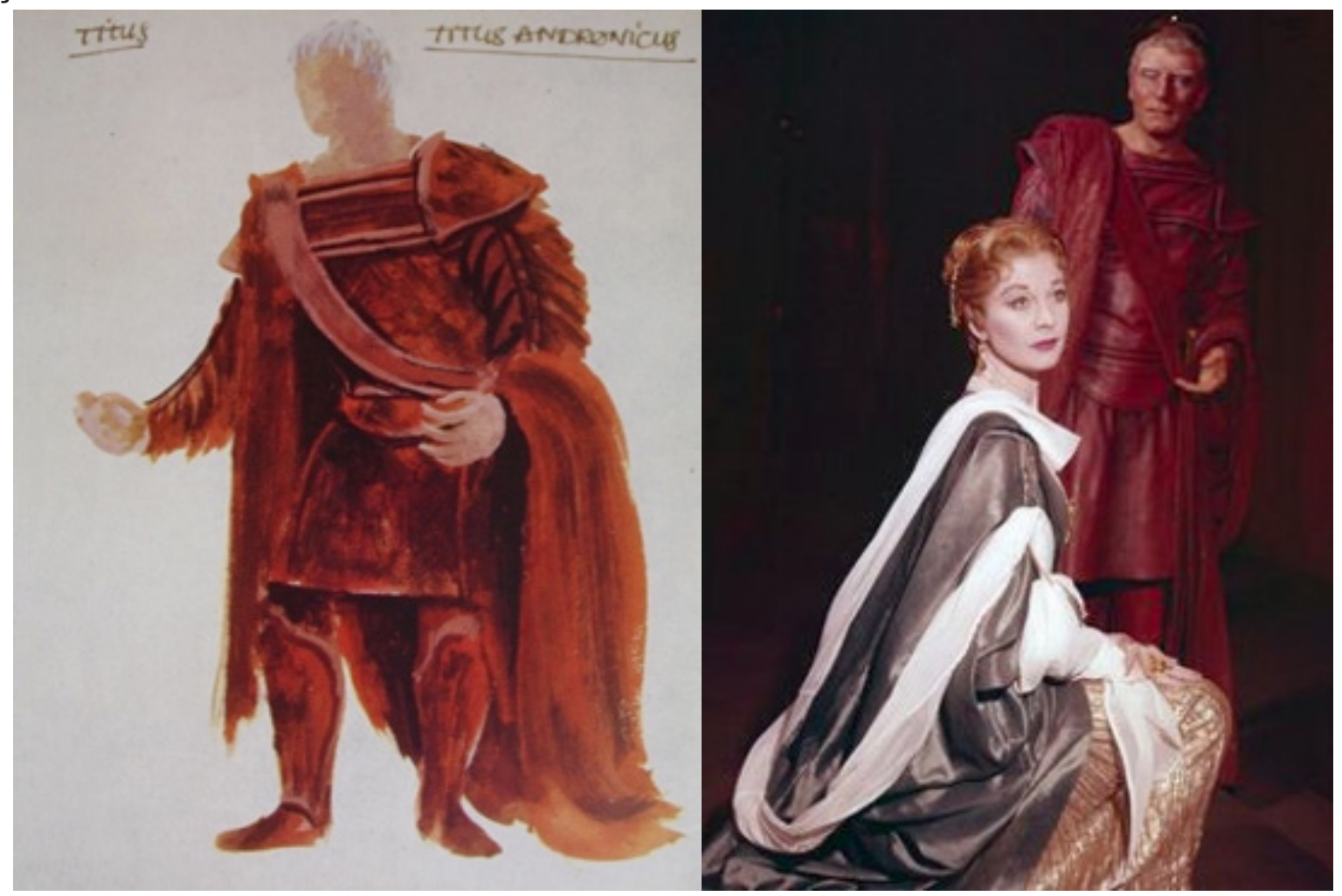

Fonte:Arquivos do RSC encontrados nos acervos do V\&A Museum. 
Fica evidente, desse modo, que os trajes de Titus Andronicus foram baseados em uma construção bastante realista. Observa-se que foram inspirados em uma pesquisa aprofundada sobre o universo da cultura grecoromana, como o largo vestido proposto para Lavínia ou as túnicas das demais personagens. Em relação ao espaço de representação do espetáculo, destaca-se que o mesmo foi encenado no Shakespeare Memorial Theatre (figura I5), em Stratford-upon-Avon, um teatro convencional que tem como conformações espaciais possíveis o palco elisabetano e a habitual caixa cênica do teatro all' italiana, uma vez que a Royal Shakespeare Company é uma das companhias teatrais inglesas mais tradicionais.

Figura 15 - Imagem de Cena de Titus Andronicus (1955) direção e cenário propostos por Peter Brook.

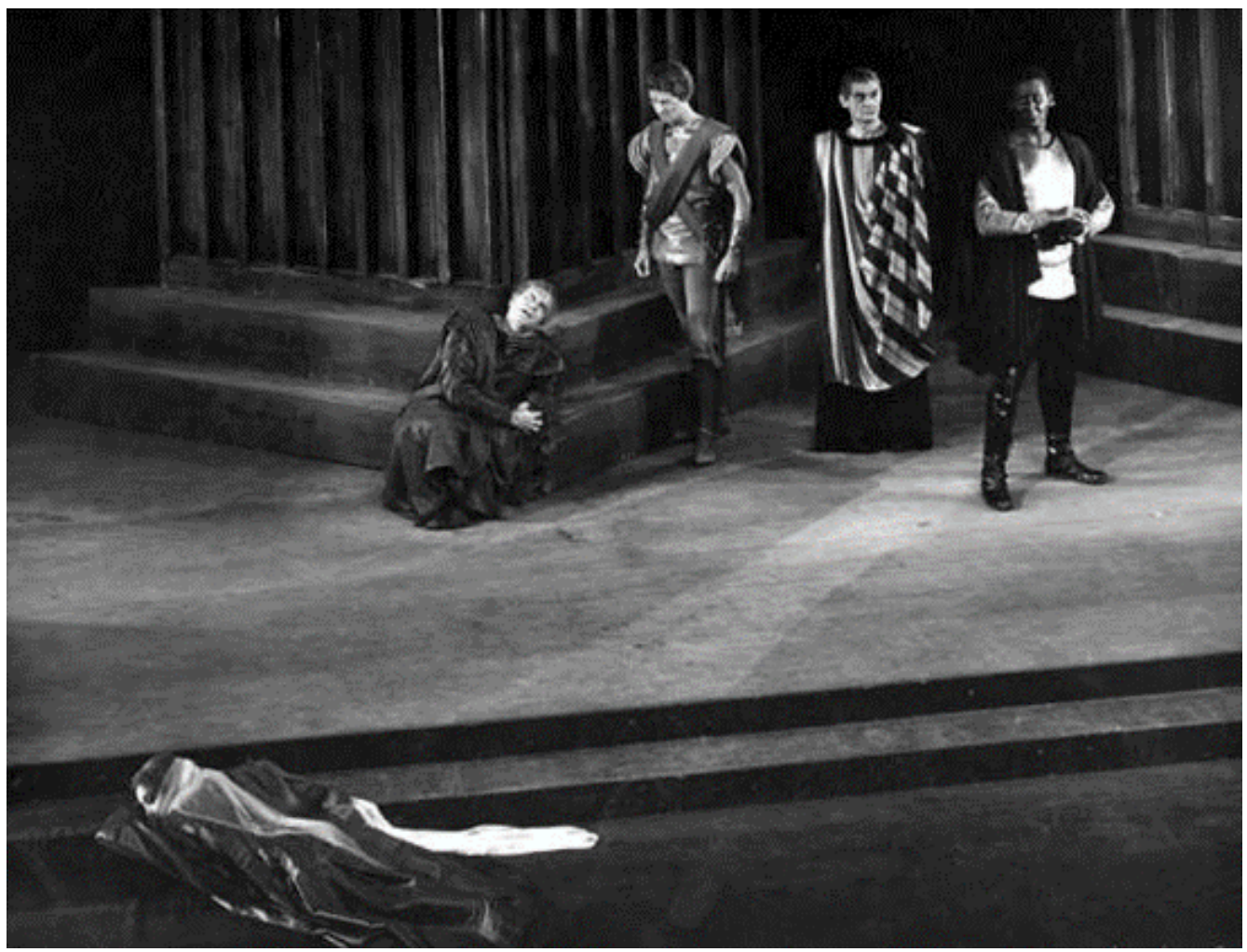

Fonte:Arquivo Vivian Leigh. 
Sobre a concepção dos cenários da peça, Brook (2000) revelou, em Fios do Tempo, que depois de sua última apresentação, se deparou, por acaso, com a cópia original do texto: folheou a última página e encontrou nela um esboço esquecido de quando havia iniciado o processo de concepção. Este desenho foi rascunhado durante a primeira leitura com os atores porém depois dessa leitura, não havia mais se deparado novamente com o texto. Ao resgatá-lo, percebeu que já estava esboçado, nessa página, o cenário completo que permaneceu como resultado final do espetáculo. Mas, para sua surpresa, este desenho havia sido deixado de lado e haviam experimentado diversas outras tentativas, com modelos de papel e cartolinas pintadas, até voltarem para esta primeira ideia.

É importante salientar que, mesmo que já houvesse chegado a um resultado semelhante ao que se concretizou no primeiro esboço, nesta montagem Brook iniciou o processo de construção dos elementos visuais que permaneceram durante todas as montagens que vieram a seguir. Trata-se da investigação dos cenários e trajes de cena a partir das ideias que os atores trazem para os seus ensaios. O diretor mencionou que, para ele, naquele tempo uma peça não poderia existir sem imagens no palco. Acreditava que fosse vital desenvolver uma metáfora para a cenografia, de modo que as cortinas, ao serem abertas, pudessem levar os espectadores a um mundo desconhecido (BROOK,
2000).

Sendo assim propôs, para esta montagem, uma pequena escada com dois níveis distintos, além de grandes colunas clássicas pintadas de preto e dourado. Vale ressaltar que elas se abriam em diferentes níveis para revelar os aposentos vermelho-sangue ou a floresta impenetrável (figura 16), conforme a necessidade exposta no texto. Esse mecanismo cênico se revelou bastante simples, pois facilmente o corpo das colunas se abriam e exibiam formas distorcidas que balançavam e sugeriam as árvores sinistras da floresta. 
Figura 16 - Cena em que a coluna se transforma em Floresta - Titus Andronicus (1955) cenário de Peter Brook.

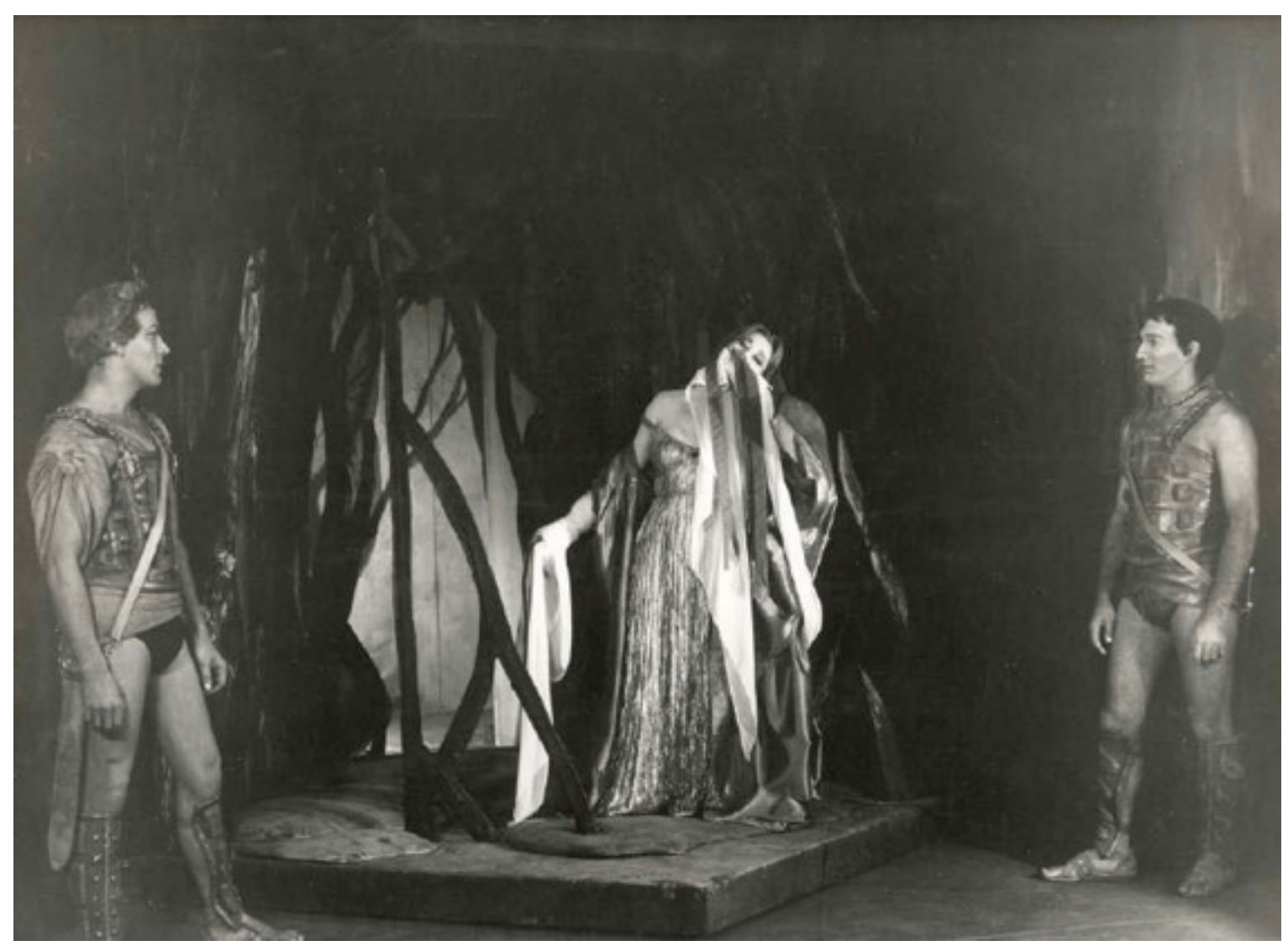

Fonte: McBean (1955).

Nos registros fotográficos encontrados, é possível observar que o cenário era composto, também, por adereços e objetos que eram introduzidos em cena pelos atores tais como: a mesa de jantar da cena final (figura 17), a escada de madeira, em que Aarão é forçado a subir pelo exército dos godos, que se transforma em uma jaula (figura 18). 
Figura 17 - Cena do banquete final - Titus Andronicus (1955). Mesas e plano superior em outro nível.

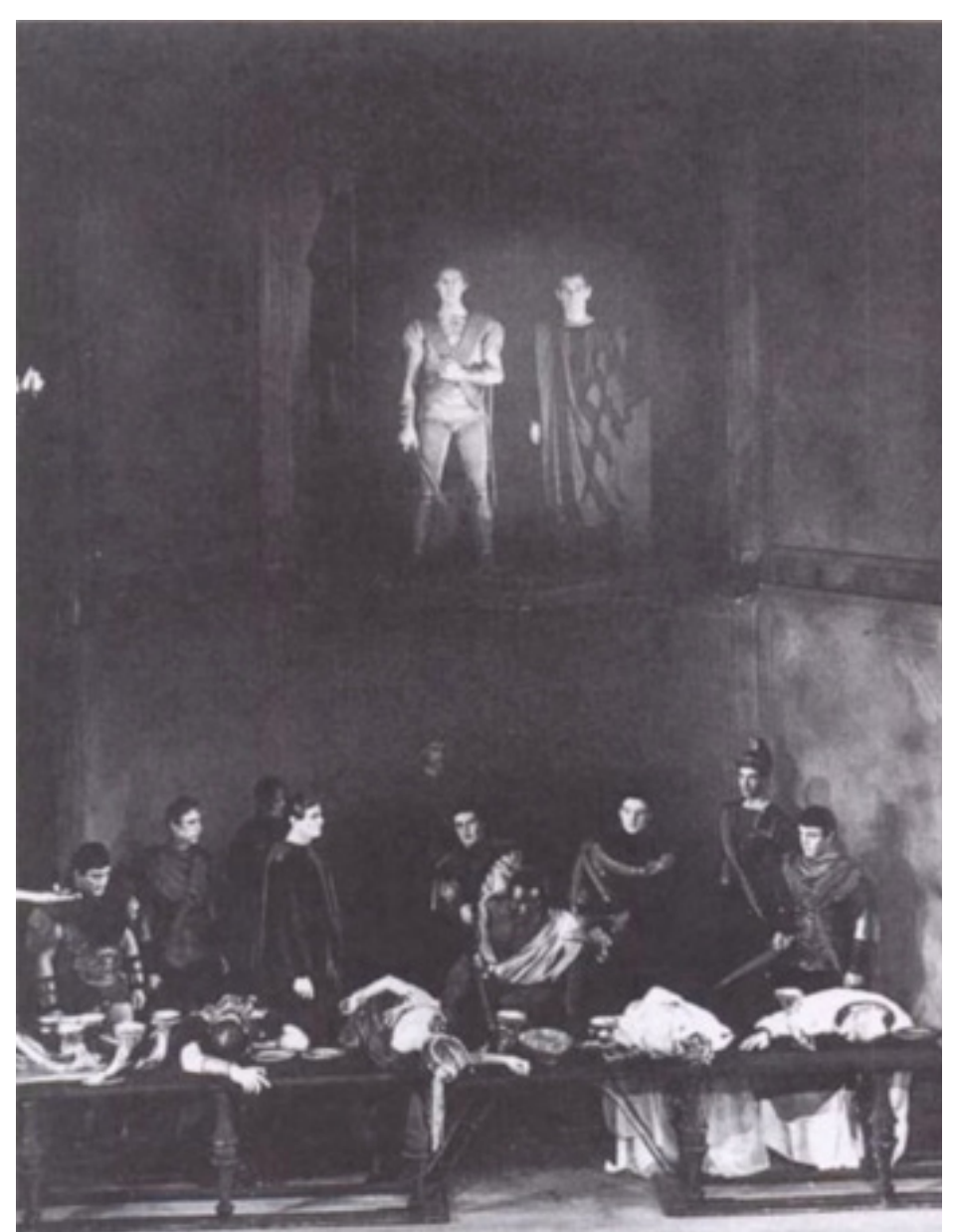

Fonte: Brook (1987, p. 53)
Figura 18 - Cena em que a escada se transforma em jaula - Titus Andronicus ( 1955) cenário de Peter Brook.

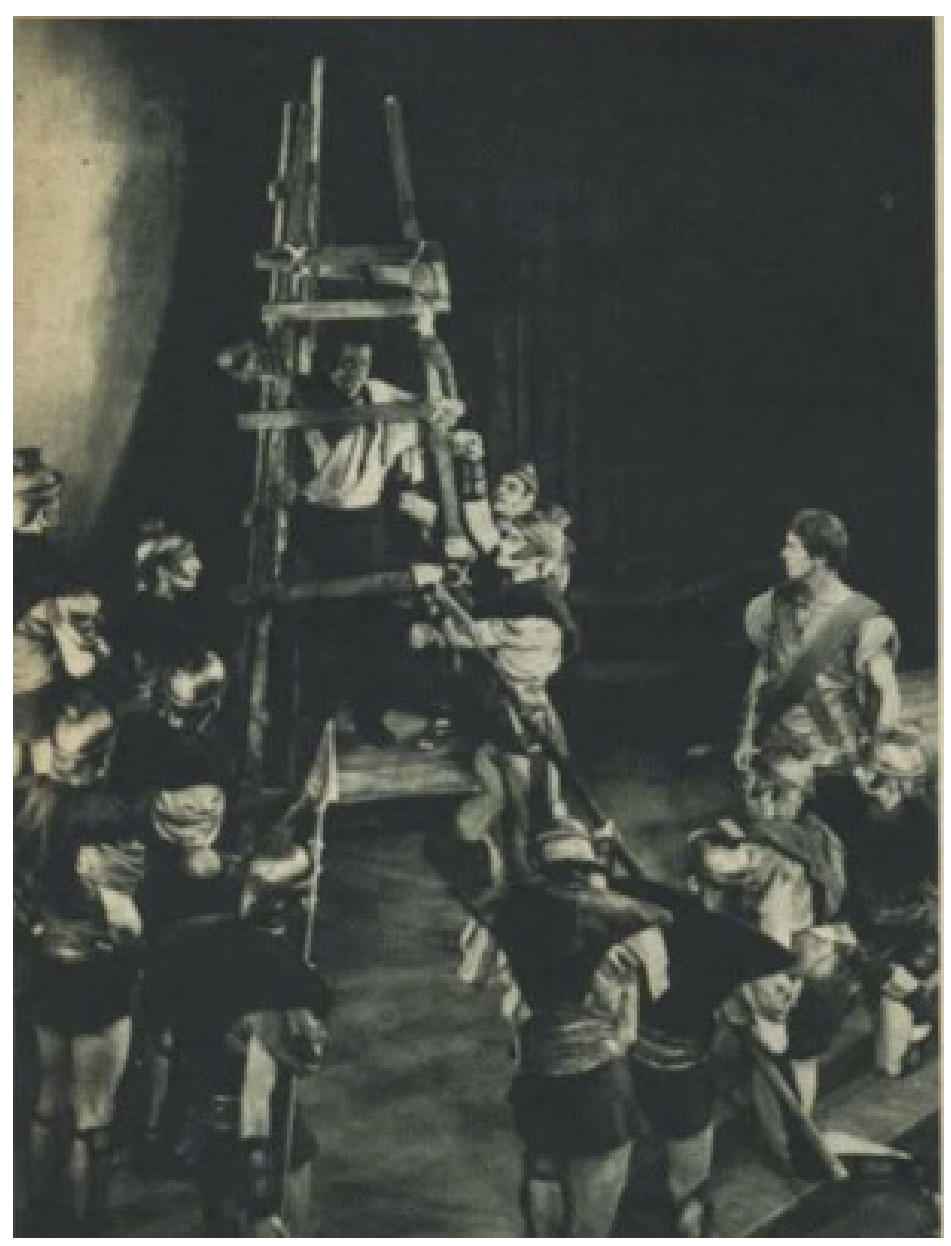

Fonte:Arquivo Vivian Leigh. 
Evidentemente, naquele momento, a proposta para os cenários do espetáculo ficou mais próximas do realismo simbólico, uma vez que tentaram reproduzir, de algum modo, historicamente, a imagem que se tinha da época do Império Romano. É importante ressaltar que Brook ainda estava amadurecendo como diretor. Além disso, devido às circunstâncias da época, dificilmente seria possível propor qualquer desenho para os cenários e trajes de cena que fugissem de uma representação mais realista, baseadas na pesquisa histórica.

\subsubsection{Uma experiência performática - U.S. (1966)}

Outra experimentação relevante na trajetória de Brook foi a peça U.S., um espetáculo performático que foi elaborado como uma reflexão sobre o momento da Guerra do Vietnã. Sua importância se deve ao fato que nesta montagem houve algumas interferências na concepção do cenário e dos trajes de cena que apontam para uma nova maneira de conduzir as suas obras e, ainda, apresentam alguns indícios de uma nova forma de abordagem para os elementos cênicos dessa peça performática.

Após um breve período de afastamento do teatro, Peter Brook entrou, efetivamente, para a Royal Shakespeare Company, em 1962 e começou a experimentar uma nova etapa em sua carreira. Brook (2000, p. 186), até então "nunca havia questionado de fato a ideia de trabalhar nas 'duas salas', pois esse era o único teatro que eu conhecia: de um lado estava o palco; do outro, o auditório". Durante toda sua experiência anterior, seus atores estavam em oposição aos espectadores. Queria partir para uma experiência em que ambos, intérprete e espectador, estivessem dentro do mesmo campo. Porém não tinha a menor ideia de como começar a perseguir este objetivo.

Esta situação começou a ser alterada quando Peter Hall o convidou para se juntar à direção da Royal Shakespeare Company. Em resposta, a única condição imposta por Brook foi ter uma unidade independente de pesquisa para explorar, na prática, suas reflexões sobre o fazer teatral. Em contato com o americano Charles Marowitz, na época editor da revista de teatro Encore, formou o grupo LAMDA (London Academy of Music and Dramatic Art) para explorar suas ideias - grupo este que foi denominado de "o Teatro da Crueldade" em homenagem a Antonin Artaud.

Embora a teoria do teatro nunca houvesse the interessado conforme explicita em Fios do Tempo, Brook (2000, p. 187) admirava "a intensidade das posições que Artaud tomara em relação a salvar o teatro de sua época". Afirma que o teatro que estava experimentando não significava a reconstrução do teatro proposto pelo diretor francês, pois não pretendia questionar sobre a 
experiência individual e social e o sentido metafísico de terror e espanto.

Realizou, na sequência, a montagem de quatro espetáculos sob influência das teorias de Artaud, a saber: Teatro da Crueldade (1964), Marat-Sade (1964), U.S. (1966) e A Tempestade (1968) - este último que será abordado no capítulo 5 , quando será apresentada a análise do espetáculo montado pelo mesmo diretor em 1990.

O primeiro deles, Teatro da Crueldade (1964), deu origem ao grupo de pesquisa com $\circ$ mesmo nome dentro da LAMDA. Tratava-se de uma performance que foi apresentada como um working in progress para a plateia. Eram vários fragmentos com gritos fantasmagóricos, longos silêncios, borrifos de tinta vermelha, Glenda Jackson totalmente nua e falas de Hamlet embaralhadas sem qualquer ordem aparente. Brook (2000, p. I9I) disse que essa apresentação "proporcionou mais motivos para as muitas sobrancelhas que se erguiam com espanto e os jocosos apartes nos bastidores".

A segunda montagem ocorreu no mesmo ano que a pesquisa anterior e culminou em um formato mais convencional com o espetáculo A Perseguição e o Assassinato de Jean-Paul Marat Representados pelo Grupo Teatral do Hospício de Charenton sob a Direção do Senhor de Sade (1964) ou Marat-Sade, de Peter Weiss. A ação proposta pelo texto colocava em discussão o processo revolucionário francês de 1789 em que os internos do hospício de Charenton, liderados por marquês de Sade, encenaram $\circ$ assassinato de Jean-Paul Marat, que foi morto pela girondina Charlotte Corday. A montagem utilizou cenários bastante simples e $\bigcirc$ palco estava praticamente vazio, com um praticável ao fundo e alguns objetos essenciais, para não se sobressaírem em relação ao assunto que estava em discussão.

Neste espetáculo um dos pontos de convergência sobre o aprofundamento das técnicas de Artaud, foi, de acordo com Brook (2000), a manifestação sobre a possessão. Porém sugeriu que deveria haver uma conexão entre possessão e inteligência, ao invés de aproximá-la dos rituais dionisíacos. $\mathrm{O}$ ator deveria explorar associações, flexibilidade e o sentido de prontidão, com o objetivo de ativar conexões entre os processos interiores e exteriores da construção da personagem. De acordo com Brook (2008, p. 33), “Marat-Sade foi bem recebida em Londres, não tanto por ser uma peça sobre a Revolução Francesa, a guerra e a loucura, mas por ser um ótimo exemplo de teatralidade".

Antes de apresentar o processo de concepção do espetáculo U.S., é relevante destacar que as experiências performáticas que ocorreram no começo da década de 1960, eram uma retomada da linguagem das experiências performáticas que remontavam ao início do século $X X$ com os encontros dadaístas no Cabaret Voltaire, a partir 
de 1916, e das experimentações na Escola Bauhaus; e tiveram uma estreita relação com o fazer teatral do período dos anos de 1960, uma vez que envolviam o público em uma participação ativa, com o intuito de provocar ações não previstas durante o processo de criação. Nessa mesma época, o artista Allan Kaprow utilizou o termo happening, também como forma de manifestação artística espontânea. Cabe destacar que, como surgimento desta expressão artística é contemporânea à proposta de Peter Brook, e seria inevitável que em algumas experiências, denominadas por ele como "mais livre", fossem embasadas em alguns conceitos performáticos. Dentre elas destaca-se U.S., uma peça engajada sobre a Guerra do Vietnã, concebida com bases na estrutura do happening. Para Brook (2000) tratava-se de uma guerra inexplicável que movimentou a companhia a criar coletivamente um espetáculo, o mais rápido possível, como forma de refletir sobre o que estava se fazendo no Vietnã. $\bigcirc$ grupo de artistas tinha a sensação de que o assunto deveria ser discutido por meio da arte. Porém havia uma questão: como colocar em cena de eventos atuais sem criar um Teatro Documentário?

Em dezembro de 1965, Brook teve uma reunião com seus colaboradores e, durante o encontro, se colocaram preocupados com os desdobramentos da guerra. Questionavam sobre como a vida da população residente em Londres era afetada pela consciência dos eventos que estavam ocorrendo no Sudeste Asiático. Naquele mesmo momento veio à tona a questão central de Bhagavad-Guita, quando um guerreiro prestes a ir para a batalha, pensa: "Devo lutar?" Parecia para o diretor que dar um retorno negativo à questão da mitologia hindu seria o mais sensato, porém, como as pessoas estavam efetivamente lutando no Vietnã, proferir preceitos morais naquele momento seria um gesto inútil.

Sentiu que o espetáculo deveria ser feito de uma nova maneira e, nesse caso, a urgência foi mais importante do que a arte. $O$ trocadilho do título já expressava as intenções do grupo. Deveria se referir tanto à situação dos Estados Unidos (United States), mas não poderia ser descrita de maneira como se fosse um problema distante, referente apenas a "eles"; U.S. significa em inglês também a palavra "nós", o que evidenciava que as questões com a situação no Vietnã, também era responsabilidade de todos.

$\mathrm{Na}$ equipe de U.S., muitos dos coautores eram socialistas devotos, enquanto a política dos atores era fundamentalmente emocional e respondia instantaneamente à injustiça e ao sofrimento. Segundo Brook (2000, p. 193), em Fios da Vida,

Quanto à ideologia não tínhamos qualquer base de acordo, mas a imediaticidade angustiante da destruição sem sentido nos uniu. Isso nos levou a territórios muito novos 
na ocasião: improvisávamos, por mais inadequadamente que isso se desse, as brutais crueldades que queríamos retratar ao fazermos exercícios que simulavam mutilações, sacrifícios e morte.

Os atores, em sua maioria, já haviam participado de montagens anteriores desenvolvidas na Royal Shakespeare Company sobre a temática do Teatro da Crueldade de Artaud. A elaboração do texto foi concebida a partir da reação do grupo de atores e pesquisadores teatrais que já estavam trabalhando com Brook e nesse processo, eles perceberam que o Vietnã era uma situação muito mais intensa, intensa e relevante do que qualquer drama que já havia sido publicado anteriormente.

Era urgente discutir não sobre as guerras antigas que ocorreram no passado, supondo que fossem mais vivas do que as atrocidades contemporâneas ao espetáculo. Assim iniciaram o processo com o intuito de promover uma reflexão sobre a situação vietnamita do momento. Todos estavam saturados dos frequentes noticiários, reportagens e programas de televisão. Sentiam que a superexposição aos horrores da guerra já não tinha mais efeito sobre a população.

Porém, se fosse colocada no teatro em uma situação ritualizada, seria possível refletir sobre os acontecimentos de uma maneira distinta. Brook não tinha pretensões que a peça convertesse ninguém. Contudo o espetáculo poderia plantar uma semente de mudança, de modo que, quando as pessoas fossem confrontadas, mais tarde, por situações semelhantes, poderiam reagir de outra forma. Conforme ressaltado por Albert Hunt, autor colaborador de Brook no processo, "se apenas uma ou duas pessoas começassem a mudar, o trabalho teria valido a pena" (HUNT; REEVES, 1995, p. 97).

grupo verificou se haveria alguma obra já realizada que refletisse sobre esse conflito, porém, como era esperado, perceberam que não havia nenhuma obra acabada sobre a questão. Foi então que uma equipe formada por 25 atores, um grupo de autores dentre eles Hunt, Chrales Wood e Geoffrey Reeves, a cenógrafa e figurinista Sally Jacobs, o poeta Adrian Mitchell e o compositor americano Richard Peaslee, liderados pelo diretor inglês, decidiram investigar por alguns meses a situação do Vietnã. Sabe-se, mediante relatos de Brook (2000, p. 194), que tiveram

[...] acesso a documentos que nos permitiram reconstruir de maneira precisa muitas das assombrosas técnicas do exército americano que eram usadas para treinamento de tortura. Deciframos a busca cega pela estética em muitas das imagens dos fotógrafos de guerra que ganharam prêmios e ouvimos em fitas a pueril risada de deleite das tripulações dos bombardeiros ao assistir aos lampejos coloridos e às pequenas lufadas de fumaça branca que transformavam em 
uma cidade de brinquedo as vilas e as vidas humanas que estavam destruindo. Ao mesmo tempo tentamos entrar no espírito do próprio Vietnã, estudando o seu teatro popular e explorando as técnicas asiáticas nas quais lendas antigas ainda eram encenadas por trás do campo de batalha.

Receberam visitas de correspondentes de guerra, militares subversivos e autores engajados que propuseram esquetes para serem incluídas no material do espetáculo. Conforme mencionado anteriormente sobre a questão do texto do Bhagavad-Guita, esta era indagada pelo grupo a todo o momento. $O$ que aconteceria se $\circ$ general encarregado das forças americanas de repente parasse e se permitisse ponderar sobre a questão: Por que se deve lutar? $O$ acesso aos registros sobre o que estava ocorrendo na guerra forneciam informações tão contundentes e intensas que, ao longo de quinze semanas de ensaio, os atores puderam estabelecer com a situação vietnamita uma relação tão visceral, o que provavelmente não teria ocorrido se optassem por realizar um espetáculo com um texto pré-estabelecido.

A construção do espetáculo ocorreu a partir de situações que eram improvisadas. Os atores eram incentivados a se comunicar uns com os outros em ritmos e sem uso de palavras. Para Brook (2000) o texto em si não tinha uma mensagem, surgiu de um trabalho experimental de laboratório que foi elaborado a partir de uma série de tentativas para resolver um determinado problema. Como resultado, quando os atores ficavam sentados em silêncio no final do espetáculo, se colocava a cada espectador a seguinte questão: "qual a nossa verdadeira atitude, aqui e agora, em relação ao que está ocorrendo dentro de nós e no mundo a nossa volta?" (BROOK, 1989, p. 89).

A pesquisa estava voltada para a criação do que se denominou de teatro de confrontação: "o que confronta o quê, quem confronta quem?" (BROOK, 1989, p. 89). E, no caso do Vietnã, o grupo percebeu que a situação, de forma definitiva, afetava a todos, embora também não afetasse ninguém. Se as pessoas pensassem, por um só dia, no horror da Guerra e contrastassem com a normalidade de suas vidas quotidianas, certamente haveria uma tensão entre estes dois polos.

$\mathrm{Na}$ conclusão do espetáculo, que não tinha um final formal, um ator sacava um isqueiro e incendiava uma borboleta (figura 19). Todas as noites, segundo relatos, o público ficava chocado com o sacrifício, mesmo que secretamente, segundo Brook (2000), aquele fosse apenas um pedaço de papel branco dobrado. Depois desse momento ninguém no palco se movia, a ação coletiva congelava, deixando os atores e o público frente à interrogação da peça: "O que é essa infinita cadeia de massacres? Como podemos viver com ela?" 
Figura 19 - Cena do sacrifício da borboleta em U.S. (1966).

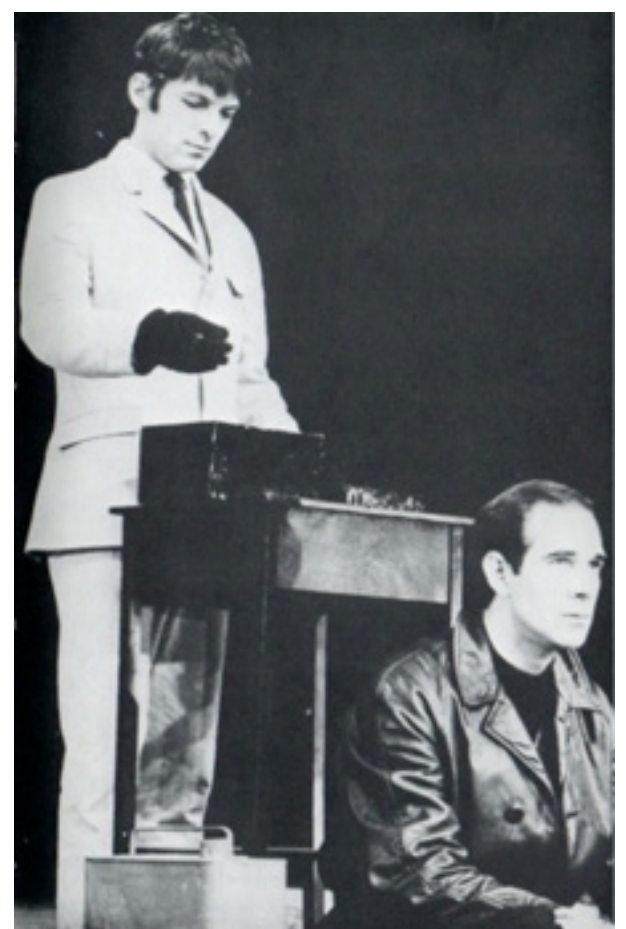

Fonte: Brook (1968, p. 185)

Segundo Hunt e Reeves (1995), a qualidade e a duração do silêncio, no final do espetáculo, dependiam do público: às vezes havia aplausos entusiasmados, o que parecia bastante incoerente; todavia, com mais frequência, a plateia partia impressionada e em silêncio. Os autores explicam que

[...] certa noite, a borboleta não se queimou: quando o ator Bob Lloyd tirou o isqueiro do bolso, uma mulher de meia-idade subiu ao palco da fila da frente e o impediu. A senhora disse: "Você vê, pode fazer alguma coisa". Quando ela viu o que ele tinha na mão, virou-se para a amiga e disse “É só papel”. Eles eram dois Quakers que já tinham visto o show uma vez do balcão; que haviam comprado os assentos na primeira fila para que pudessem parar o que achavam que era um ultraje acontecer de novo. A companhia, especialmente Bob Lloyd, admirou muito a coragem da ação (HUNT; REEVES, 1995, p. II2). 
Cada elemento do espetáculo foi criado somente para os setores específicos da população londrina que compareceram às cinquenta apresentações no Teatro Aldwych. Para o diretor, o erro cometido com a experimentação em U.S. foi a sensação de se sentirem obrigados a incluir o espetáculo em seu repertório. Um repertório se repete e, para que isso aconteça, alguns elementos devem ser fixados. As regras da censura britânica não permitiam que atores adaptassem e improvisassem nos espetáculos. Fixar, nesse caso, era o início de um deslize em direção ao "teatro morto", pois a vivacidade dos atores se esvaía à medida que diminuía o imediatismo da relação com o público e o seu tema.

A concepção dos cenários e trajes de cena do espetáculo U.S. foram desenhados por Sally Jacobs, cenógrafa e figurinista, parceira de Brook desde 1964 com a montagem de Teatro da Crueldade. Contudo, nesse processo sobre a discussão sobre a Guerra do Vietnã, Jacobs (apud HUNT; REEVES, 1995) relatou que teve problemas para chegar a uma solução tanto para os trajes de cena quanto para a cenografia. Iniciou o processo tentando juntar pedaços de elementos soltos, porém nem ela nem a direção estavam satisfeitos com a solução espacial.

Começou, então, tentando juntar pedaços de arame farpado no palco, porém como não havia um suporte que conseguisse conferir uma estrutura para a proposta, acabaram achando que não seria uma boa ideia. Em entrevista concedida a Hunt e Reeves (1995), Jacobs explicou que a estrutura não assumia uma forma. Não se sabia onde deveriam ser colocados os elementos que pareciam soltos sem criar qualquer tipo de relação. A única certeza era que o cenário aconteceria no palco do Teatro Aldwych com os pedaços de destroços que seriam explorados pelos atores em cena.

Jacobs trouxe um conceito para a cenografia, elaborado a partir de um livro de arte pop chamado de Soldado Morto. Embora ainda não fosse a solução para esse cenário, expressava muito sobre o que o grupo buscava revelar ao público. O conceito pareceu tão conectado com a proposta, que não se sabia exatamente no que iria resultar, porém tinham certeza que deveria ser aproveitado em algum momento.

Uma vez estabelecido o conceito artístico da peça, a cenógrafa relevou que completou a estruturação para o espaço cênico quando um amigo lhe disse que em todos os países envolvidos em guerra se formavam enormes depósitos de lixo, de tempos em tempos. Nesses amontoados encontravam-se diversos tipos de entulhos: coisas que sobraram, peças e mais peças de elementos culturais, carcaças de veículos, asas de avião, tanques de guerra velhos (figura 20). Parecia à designer que era exatamente essa situação que deveria ser reproduzida. 
Figura 20 - Proposta de cenário com diversos elementos descartados em situação de guerra U.S. (1966).

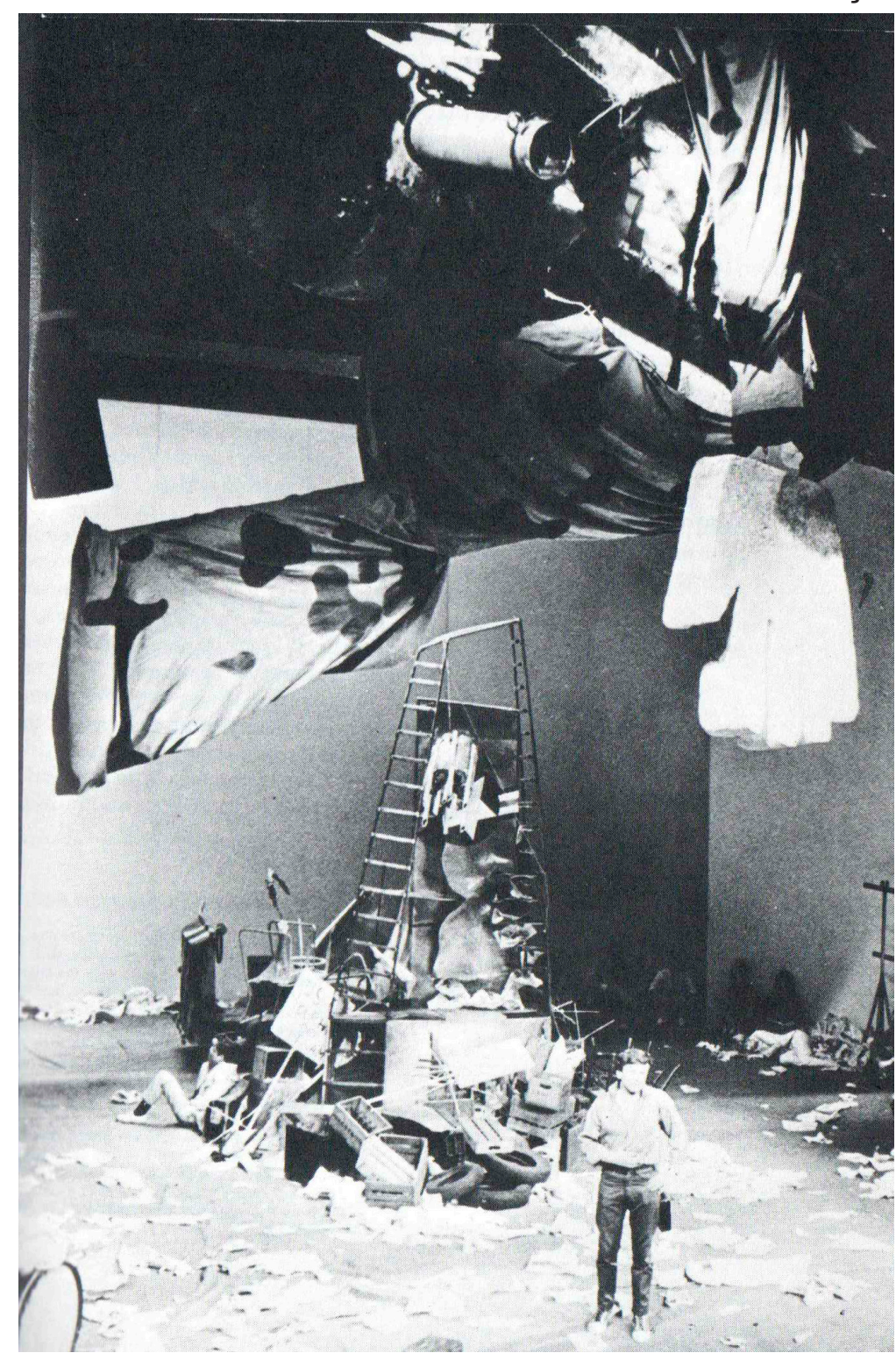

Fonte: Brook (1968, p. 91). 
Assim, a solução encontrada foi reproduzir o Vietnã devastado pela guerra com uma pilha de lixo amontoado em formato de pirâmide que os atores poderiam escalar. De acordo com relatos de jacobs (apud HUNT; REEVES, 1995), essa ideia surgiu de fotos de coleções de pedaços de aviões americanos que os vietcongues exibiam e colecionavam como suas conquistas. No centro do palco havia uma asa de avião, cadeiras velhas e pedaços de mobília que criavam a atmosfera desejada pelo grupo (figura 2I). Os atores, por sua vez, poderiam movimentar os objetos e circular por todo espaço cênico.

Figura 21 - U.S. no Teatro Aldwych em Londres.

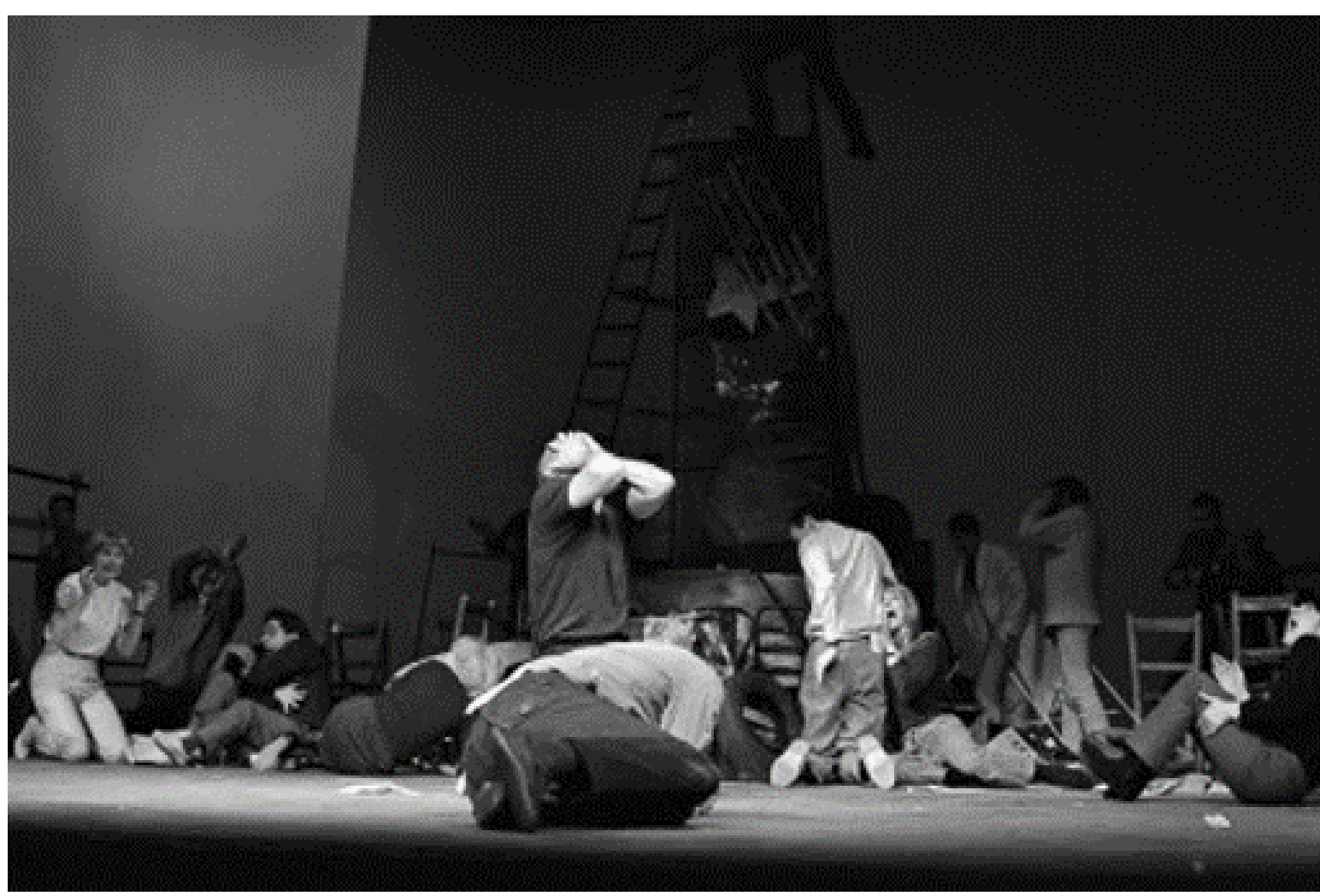

Fonte: Dorney (2015) 
No meio do palco havia uma grande e cromada cerca amarela, com uma cor muito dura e difícil de se olhar. Também faziam parte dos objetos: um jipe, bandeiras chinesas e banners de seda. Com essa proposta era possível lidar com as improvisações que surgiam dos ensaios, como a necessidade de se utilizar uma corda bamba. Para completar a ideia dos elementos de cena, em um dos encontros do grupo no apartamento da cenógrafa, ela exibiu a todos o modelo de um enorme soldado americano, deitado de bruços, que seria suficientemente grande para preencher quaisquer lacunas no palco. Era possível perceber que as feições de seu rosto (figura 22), seus braços, cotovelos, joelhos e pés haviam sido concebidos para que os atores pudessem escalar por ele. Além disso, havia um foguete, como pênis do soldado, que simbolizava ironicamente a maneira como os americanos estavam se expressando no conflito.

Figura 22 - Imagem do cenário com o formato de Soldado no espetáculo U.S. (1966).

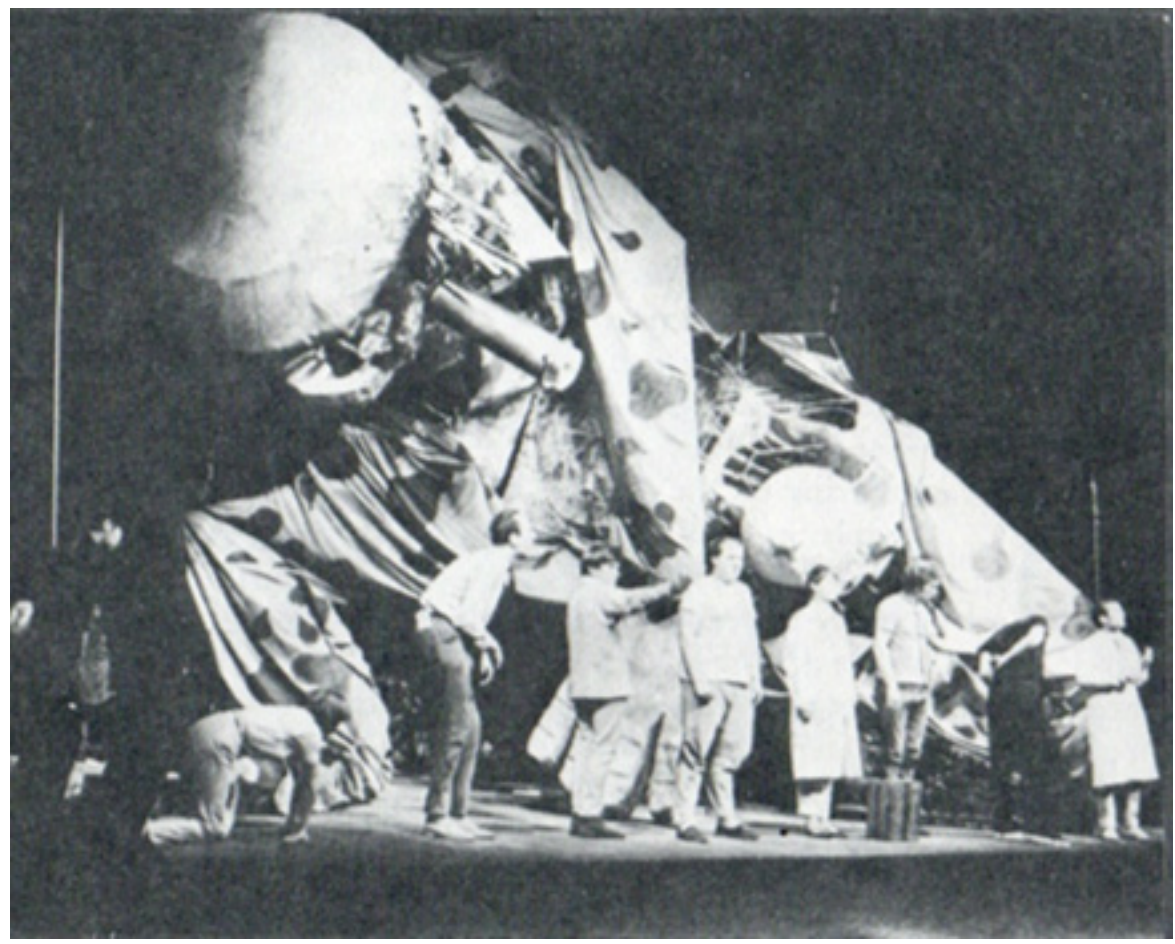

Fonte: Brook (1968, p. 125). 
Brook pareceu muito animado com o modelo apresentado e disse que acreditava que haviam descoberto o conjunto da proposta de encenação. Instruiu para que o modelo fosse construído de modo que o soldado estivesse inclinado, ocupando boa parte do palco. Mas, tendo em vista a grandiosidade em que a produção se tornaria, sobretudo para um espetáculo experimental, decidiu reconsiderar a proposta. Desse modo, o boneco do soldado foi colocado em frente ao proscênio. Quando o objeto começou a se mexer em frente ao público sentado nas primeiras fileiras do palco, manipular a marionete pareceu bastante perigoso, pois o boneco desceu tremendo e fazendo um ruído bastante estridente.

Como havia muitos problemas técnicos, principalmente envolvendo a manipulação do manequim em sua descida do arco de proscênio, ao final, o soldado ficou posicionado na frente do palco suspenso pelo teto do Aldwych. Para o público sentado em sua frente, o soldado parecia muito ameaçador. Porém se estivesse sentado no banco de trás, não conseguiriam vê-lo plenamente até que ele fosse abaixado no final do primeiro ato.

Era um fantoche de onze metros de altura com braços e pernas pendurados, cuja mão estava colocada sobre uma caixa. Na cena que mostrava a escalada da guerra, sua mão era derrubada e, então, abria-se uma paisagem de destruição na qual os atores poderiam escalar. $O$ boneco ajudou Brook a encontrar o próximo passo pois era um objeto que focalizava todo o material em um estilo teatral. A partir daquele momento o espetáculo começou a ter uma estrutura de revista musical. Todo o texto - e algumas das músicas de Adrian Mitchell - foi baseado em material documental, assim como grande parte das falas dos atores.

Em relação à elaboração dos trajes de cena, havia uma preocupação de Brook em estabelecer uma conexão direta entre os atores e o público, o que fez com que se tomasse uma decisão bastante dramática em relação aos figurinos. Como os atores estavam retratando material diretamente retirado do noticiário, encenando diálogos reais entre políticos conhecidos, interpretando pessoas famosas e vivenciando personagens de quadrinhos, era um desafio bastante significativo, para Jacobs, descobrir como eles deveriam se vestir e desempenhar todas essas funções.

Desse modo, a figurinista projetou uma série de trajes esportivos básicos, que se assemelhavam a um pijama vietnamita - alguns mais caricatos do que outros -, em que os atores poderiam adicionar adereços e outros elementos de cena quando necessário. Parecia uma ótima solução para o problema que estavam enfrentando na montagem do espetáculo, porém, quando os atores colocaram os trajes projetados, a conexão pretendida 
entre os atores e o público se perdeu. Anteriormente os atores pareciam estar falando por todos os espectadores pois pareciam pessoas reais.

Todavia, no instante em que os atores se vestiram com os trajes propostos, a peça parecia um espetáculo feito com fantasias que não tinham mais nenhuma conexão além de adereçar a própria produção. Para Brook (apud HUNT; REEVES, 1995), os trajes estavam todos errados, mas não havia tempo suficiente para que pudessem investigar o porquê. Assim, no ensaio seguinte, os atores voltaram a ensaiar sem os trajes e, para surpresa da direção, o espetáculo voltou a se encaixar. $\bigcirc$ que deixou claro que nessa produção o que mais importava era de fato conseguir estabelecer um diálogo e um embate com o momento que estavam vivendo e, principalmente, com o conflito.

Os atores deveriam, portanto, utilizar roupas do seu dia-a-dia. Quando Brook fez o anúncio de que não haveria novas propostas de trajes de cena, todos ficaram bastante apreensivos, pois essa mudança pareceu bastante radical para o grupo, o que fez, em um primeiro momento, que todos ficassem inseguros. Contudo essa escolha trouxe muito mais vitalidade aos diálogos que estavam estabelecidos em cena, como podemos observar na figura $23 \mathrm{com}$ a presença da atriz Glenda Jackson, destacada em uma bata vermelha.
Figura 23 - Glenda Jackson em U.S. utilizando trajes cotidianos.

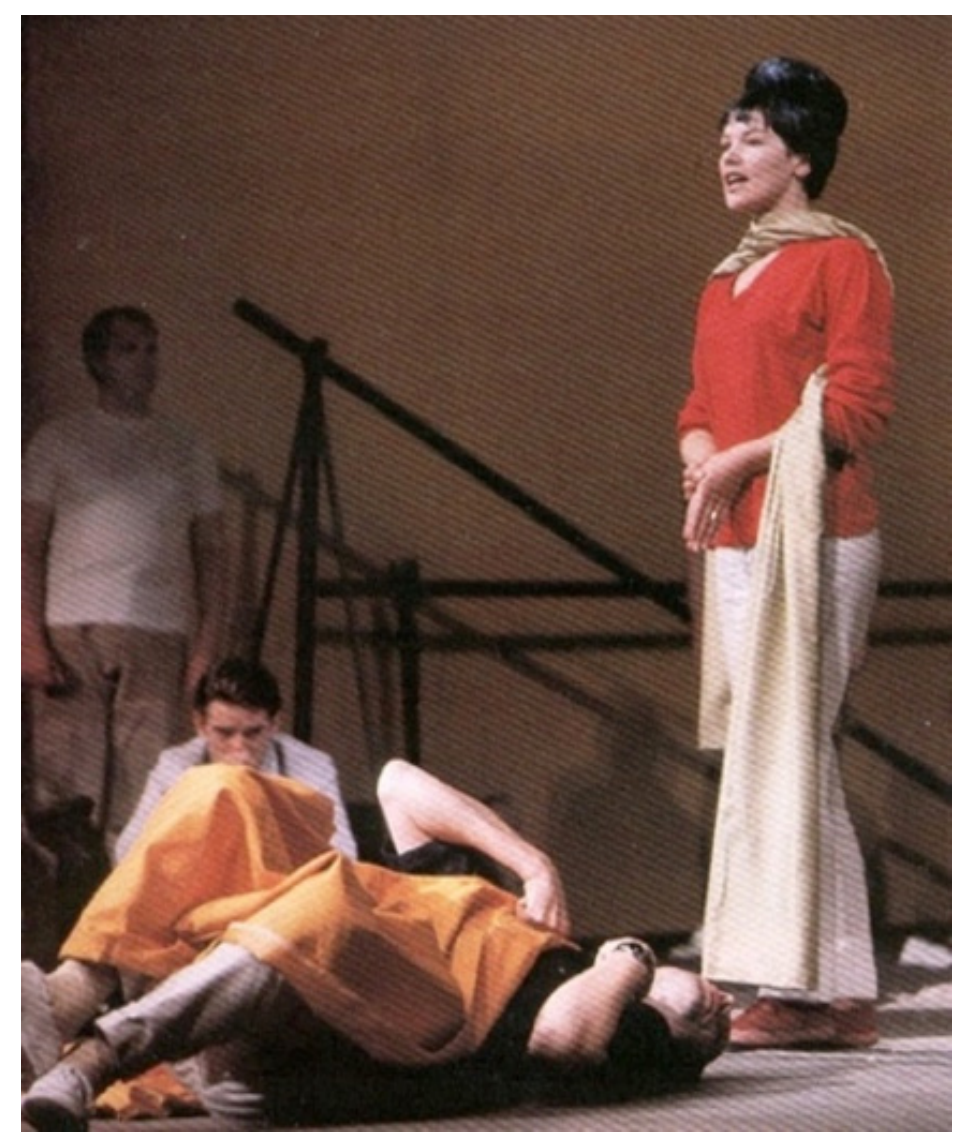

Fonte: Eichenberg (2000, p. 74). 
Hunt descreve o momento em que Brook anunciou aos atores sobre a decisão de retirar os trajes propostos.

Brook de repente interrompeu o ensaio, pediu aos atores para perceberem o que estavam vestindo e disse "É isso que eu quero que você use na peça" - depois do qual o ensaio continuou como se nada tivesse acontecido (HUNT; REEVES, 1995, p. II4).

Desse modo, os trajes originalmente planejados foram jogados fora, o que abriu espaço para roupas do cotidiano (figura 24).

Figura 24 - Atores com adereços na cabeça utilizando trajes cotidianos.

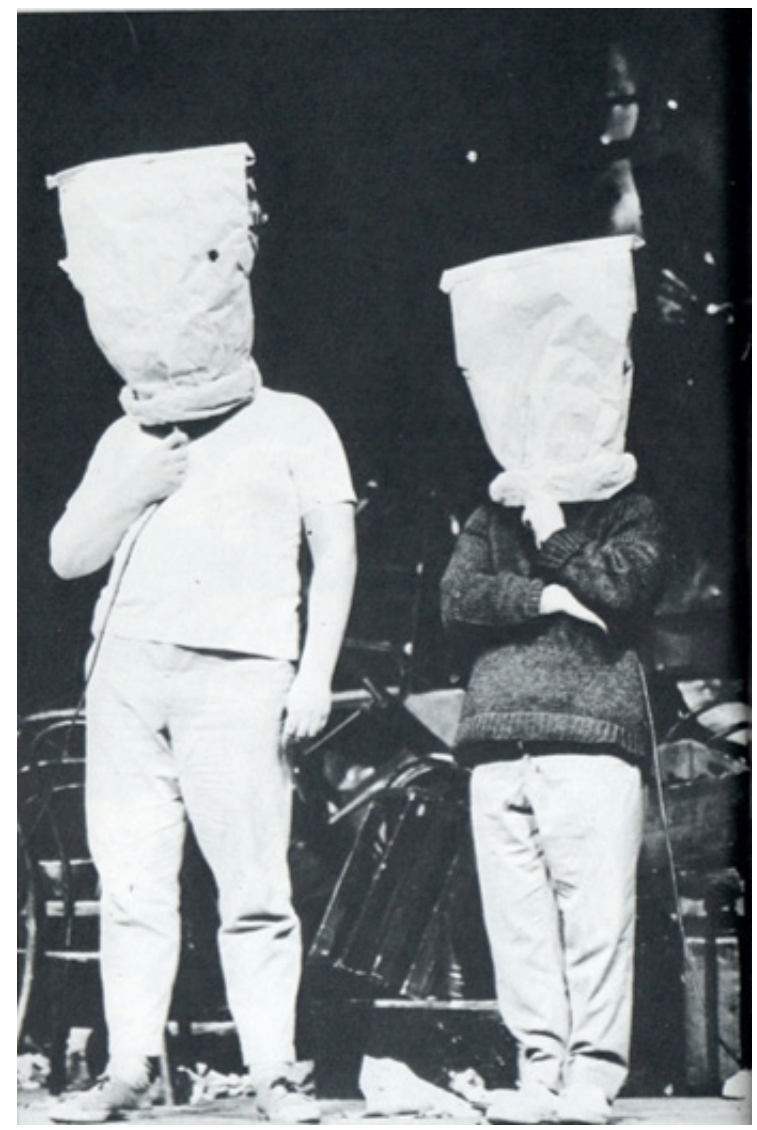

Fonte: Brook (1968, p. 130) 
A história do Vietnã foi apresentada como uma série de tableaux vivants, usando adereços de mão, chapéus e bandeiras e, sobretudo, com um ator alto e magro que personificava o Vietnã. Na Conferência de Genebra, depois da rendição francesa em Dien Bien Phu, o Vietnã foi pintado em duas cores, sendo dividido na cintura durante o espetáculo em uma representação de combate que se assemelhou a uma action painting (figura 25). Houve também uma tentativa de utilização de matérias audiovisuais de documentários justapostas em cena, assim como vídeos ao vivo, contudo essa ideia não foi colocada em prática.

Figura 25 - U.S. durante a cena de action painting, 1966.

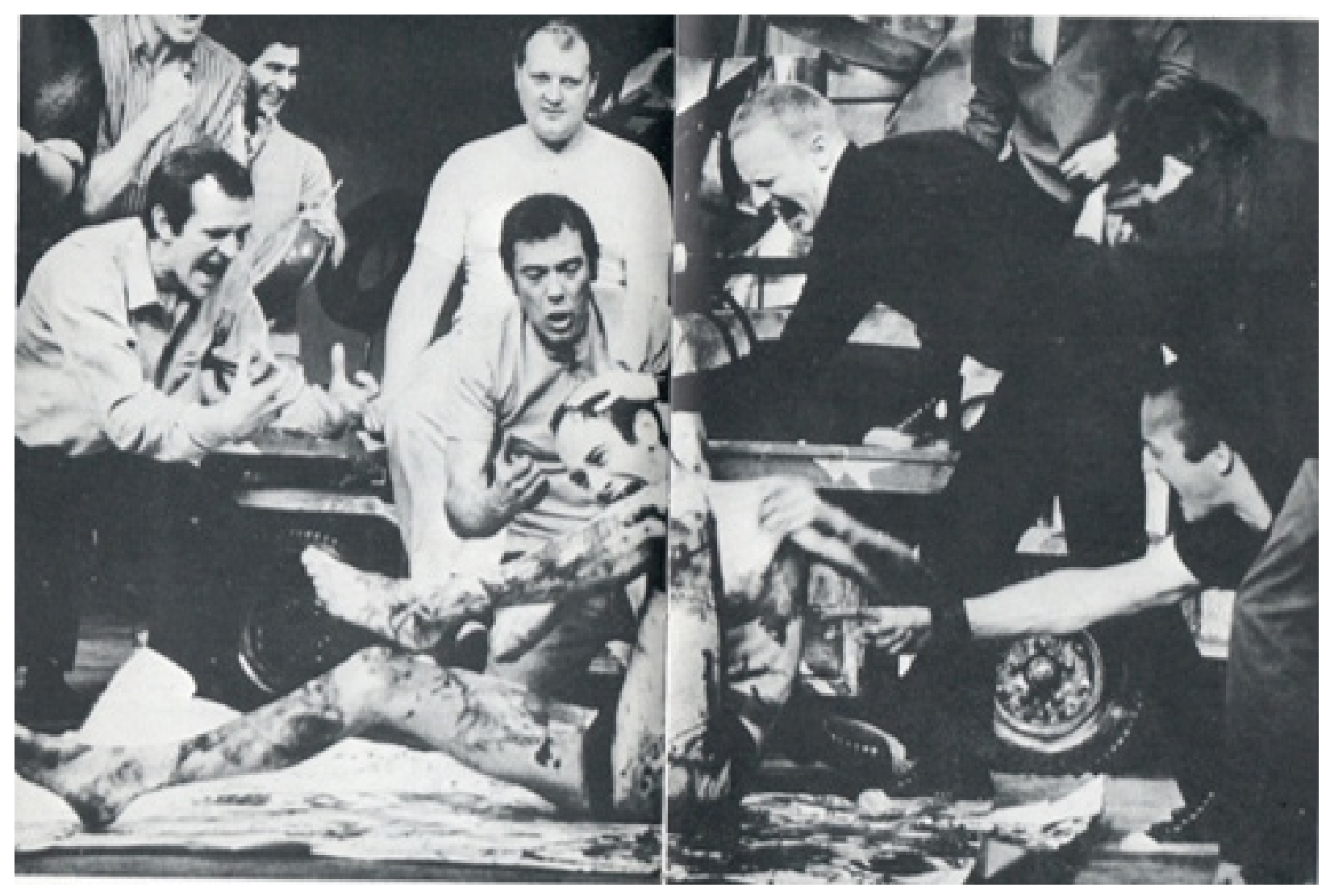

Fonte: Brook (1968, p. 54). 
O filósofo, escritor e crítico francês Jean-Paul Sartre apud HUNT; REEVES, 1995) escreveu sobre o espetáculo U.S., disse que se tratava de um acontecimento real. O problema era: o que acontece com a performance à medida em que se apela livremente à imaginação do espectador? Para Sartre, não se tratava do surgimento espontâneo de algo que é mais ou menos cruel. Sob seu ponto de vista a maioria das cenas eram uma exploração cuidadosamente pensada a partir da crueldade proposta por Artaud. Sendo assim, os espectadores deveriam ir assistir ao espetáculo com suas roupas velhas, para se sentirem mais confortáveis com o contexto e reagirem à sua própria tortura.

Não compreendia U.S. como um espetáculo teatral. De acordo com seu ponto de vista, havia uma sucessão de cenas, palavras e atos violentos sem outro propósito, senão, o de criar a confusão que inspirava dois temas: a primeira parte, o horror da guerra no Vietnã; enquanto a segunda era principalmente sobre a impotência da esquerda na realidade ocidental (SARTRE apud HUNT; REEVES, 1995). Para ele o final do espetáculo, com o incêndio das borboletas vivas, representava o happening - ou seja, algo que realmente acontece: aquilo que está vivo morre e, em situações de conflito, morre sofrendo.

No entanto para Sartre (apud HUNT; REEVES, 1995), o espetáculo não era totalmente um happening, uma vez que terminava em um silencio ensurdecedor.
O espectador era enviado de volta à sua solidão em um misto de choque, fúria e impotência. Afinal, havia algo para ser concluído? Se era verdade que a guerra no Vietnã era um crime, também era verdade que a esquerda estava completamente incapaz de fazer qualquer coisa a respeito. Finalmente o crítico francês concluía sua fala questionando se toda reflexão tinha algo a ver com o teatro.

Deve-se destacar que, em relação à experimentação cênica, apesar de U.S. se propor a ser um espetáculo performático, foi desenvolvido em um espaço em que a caixa cênica permanecia. $\bigcirc$ que evidencia que a experiência de desconstrução do espaço da representação, que ocorreu em outras obras de Brook, ainda não havia se iniciado. Em relação à proposta de cenografia, deve-se destacar que existiu uma mudança em relação ao espetáculo anterior, uma vez que não houve a necessidade efetiva de se reproduzir a realidade com uma pesquisa histórica.

Pode-se afirmar, portanto, que o espetáculo não foi performático, pois não se pretendia alterar as estruturas convencionais do teatro, ainda que a cena da borboleta tenha permitido que houvesse uma alteração na estrutura da encenação. De acordo com a classificação apresentada no apêndice, poderia se dizer que, esse cenário não seria propriamente um exemplo do que foi definido como kitsch, ainda que se utilize de uma série 
de materiais descartados em um ambiente de guerra as sucatas, como exposto por Viana e Campello Neto (2010).

Seria uma mistura de realismo atmosférico, uma vez que existia explicitamente a necessidade de ambientação da situação de guerra; e, ao mesmo tempo, um embrião de simbolismo, que era evidenciado pela proposta de construção do símbolo do soldado americano que com seu grande falo dominava o mundo. Apesar de não ter sido uma proposta inovadora do ponto de vista espacial, sem dúvida, o impacto de todas as escolhas foi muito significativo na trajetória de Brook.

Decidiu gravar, logo em seguida, um filme - Tell me lies com a mesma temática e estética obtidas no espetáculo. Além disso foi, conforme relatado pelo próprio diretor, o contato com todo o processo de U.S. que conduziu, definitivamente, a uma pesquisa bastante aprofundada, relacionada tanto com a temática da Guerra como com a da espiritualidade, para a elaboração do espetáculo Mahabharata em 1985. 


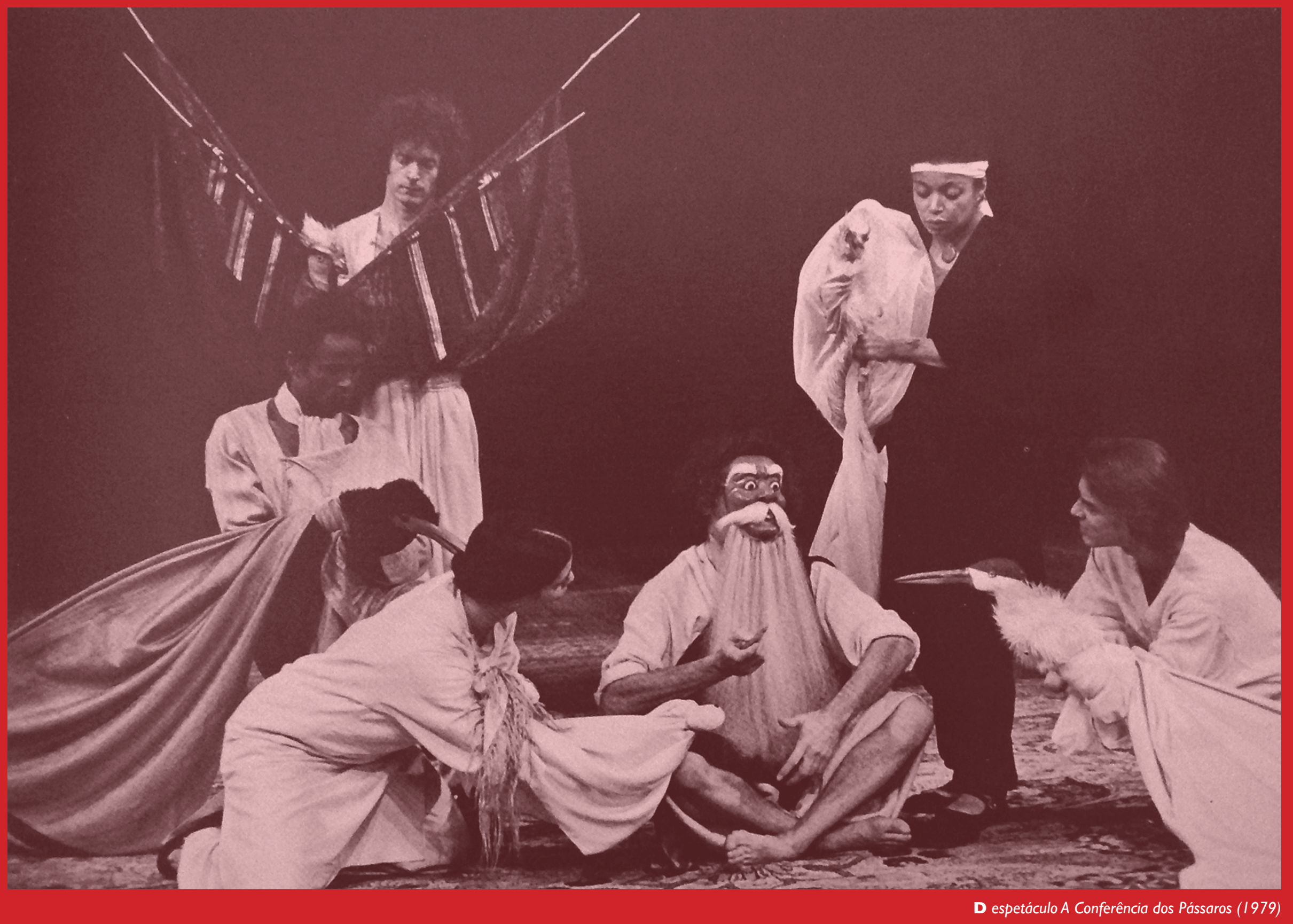





\section{AS ORIGENS DO ESPAÇO SAGRADO NO TRABALHO DE PETER BROOK: $A$ CONFERÊNCIA DOS PÁSSAROS (1979).}

Nesse capítulo pretende-se compreender o início do processo de investigação sobre o Teatro Sagrado. Para permitir um melhor entendimento sobre os textos analisados a seguir, é importante uma breve explanação sobre o processo de criação do Centro Internacional de Pesquisa Teatral (CICT). Logo após, parte-se para a análise do primeiro trabalho a ser referido nesta pesquisa, que abriu caminhos para que o diretor pudesse, efetivamente, abordar um texto cuja temática também é considerada sagrada: trata-se de $A$ Conferência dos Pássaros (1979).

\section{I A CRIAÇÃO DO CENTRE INTERNACIONAL DE CRÉATIONS THÉÂTRALES (CICT)}

Em 1968 Peter Brook recebeu um convite do ator e diretor Jean-Louis Barrault para criar um workshop com atores, escritores e diretores de diversas origens étnicas e culturais no Théâtre des Nations, em Paris. Era a possibilidade que surgira para investigar os aspectos fundamentais do teatro, considerando tratarse de um grupo de artistas bastante heterogêneo e uma interessante mescla de diferentes culturas. Na realidade, conforme mencionado anteriormente, era também a oportunidade que Brook teria de ficar mais próximo de sua nova mestre espiritual, Madame de Salzmann. 
Ocuparam uma sala de exposição em uma antiga fábrica de móveis nacional - Le Mobilier National - no bairro de Gobelins, a sudoeste de Paris. A princípio - encenador decidiu provocar o grupo de artistas envolvidos no workshop, constituido especialmente por atores internacionais, a trabalhar com a reflexão crítica sobre os acontecimentos e o caos político que a França vivenciava naquele momento, em que estudantes e membros da classe trabalhadora questionavam 0 governo de Charles de Gaulle. Contudo, por se tratar de um grupo internacional, Brook decidiu abandonar a montagem de um espetáculo baseado no texto $O$ Balcão, de Jean Genet.

Em substituição à proposta, o diretor escolheu trabalhar um texto que já havia realizado algumas montagens com a Royal Shakespeare Company em Stratfordupon-Avon: A Tempestade, de Shakespeare. Apesar de já ter realizado duas montagens anteriores, Brook ainda acreditava que não havia encontrado a essência do espetáculo e decidiu desenvolver a busca junto com o grupo. Como o tempo disponível para o workshop era escasso, logo os atores começaram a realizar as improvisações sobre as personagens. $\mathrm{Na}$ realidade todos trabalhavam a mesma cena do espetáculo que estavam estudando.

Infelizmente, devido a eclosão da revolta estudantil que ficou conhecida como Maio de 1968 na França, os planos de se mudar para a cidade e concretizar seu projeto de pesquisa teatral precisaram ser adiados. Brook decidiu retornar para Londres; porém, como atores de diversas partes do mundo se disponibilizaram a acompanhá-lo, tentou intervir junto ao British Arts Council e a Royal Shakespeare Company para dar prosseguimento ao trabalho e não dispersá-los. Foi autorizado a permanecer com o grupo pelo período de três meses; assim, com essa primeira conformação de atores internacionais, deu prosseguimento a um projeto piloto no Round House, apresentando uma versão do texto desconstruído de A Tempestade (1968) como work in progress.

Naquele mesmo ano encenou com a Royal Shakespeare Company, o espetáculo Édipo de Sêneca (1968) e, em 1970, estreou um espetáculo alegre, de enredo bastante complexo e audacioso, peça teatral que rendeu muitas críticas positivas devido à ousadia de sua montagem: Sonho de uma Noite de Verão. Trata-se da primeira experiência do diretor ao colocar em cena o conceito de espaço vazio - grande diferencial dessa montagem -, com a representação encenada em uma caixa cênica branca com poucos elementos visuais em cena e com o elenco permanentemente no palco.

Logo após a conclusão da temporada de viagens com Sonho de Uma Noite de Verão, e exatamente dois anos depois das experiências iniciais com o grupo 
internacional, Brook, juntamente com a produtora Micheline Rozan, formulou os princípios para criação do Centre Internacional de Créations Théâtrales (Centro Internacional de Pesquisa Teatral - CICT), que foi estabelecido por sua conta própria. A partir dessa decisão, Brook e sua família se mudaram para Paris e, a princípio definiu um período mínimo de três anos para o desenvolvimento da pesquisa.

Nessa temporada estariam também incluídas expedições: ao Irã; à África ocidental percorrendo Benim, Niger, Mali, Algéria e Nigéria; e aos Estados Unidos - iniciando na região dos camponeses na baixa Califórnia, passando pelas regiões indígenas de Minnesota, Connecticut, até ao bairro negro do Brooklin em Nova lorque. Algumas pessoas, de todas as partes do mundo, ligadas ao teatro: encenadores, escritores, músicos, cenógrafos, figurinistas, artistas e atores, foram convidados para investigar questões fundamentais sobre teatro: "O que é o teatro?"; "O que é um ator?”; “O que é o público?”, com $\circ$ intuito de examinar essas questões sem ideias preconcebidas.

De acordo com Croyden (2003), Brook buscava atores que estivessem abertos ao processo que iriam abraçar; que soubessem se comunicar com os demais de forma livre, e que, com sua arte, conseguissem ultrapassar a imaginação do encenador. As audições para integrar a companhia duraram cerca de um mês. Passaram por esse encontro mais de I50 atores, designers e diretores das mais diversas origens finalmente, o grupo original foi formado por: quatro artistas americanos - Andrei Serban, Andreas Katsulas, Michelle Collison e Lou Zeldis; um japonês - Yoshi Oida; um africano - Malick Bowens; uma alemã - Miriam Goldshmidt; dois ingleses - Bruce Myers e Natasha Parry; e um francês - François Marthouret.

Posteriormente se vincularam ao Centro os compositores Richard Peaselee, Elizabeth Swados; e a atriz Helen Mirren. Sally Jacobs, parceira de Brook por muitos anos, também foi convidada a integrar o grupo como designer de cenários e figurinos e contribuiu com a pesquisa deles até o espetáculo $A$ Conferência dos Pássaros (1979). Desse modo, o grupo estava finalmente formado, misturando diversas etnias em uma pequena comunidade "mundial".

Conforme explicitaram alguns de seus colaboradores mais frequentes, dependendo das necessidades do projeto a ser desenvolvido, alguns outros artistas eram convidados a participar, dentre os quais devem ser citados: Moshe Feldenskrais, mestre de consciência corporal; Joseph Chaikin, diretor convidado; Kristin Linklater, professor de voz; e, Cathy Berberian, cantor. Em relação aos ajustes do espaço cenográfico, deve ser destacado o diretor técnico Jean-Guy Lecat, que passou a integrar a companhia seis anos após o seu 
estabelecimento. Ele foi responsável pelos ajustes relacionados ao espaço cênico e teatral. E, finalmente, a cenógrafa e figurinista Chloé Obolensky que se integrou ao grupo em 1981, na criação dos cenários e trajes de cena de 0 Jardim das Cerejeiras.

Inicialmente o grupo recebia o apoio de fundações, que realizavam doações, e do Ministério da Cultura francês, que concedeu um local no Centro de Exposições das Tapeçarias Nacionais de Gobelins - Mobilier National para estabelecerem ali seu espaço de experimentação. Tratava-se de uma sala comum, sem ornamentos, com cem metros de comprimento por cem metros de largura. Suas paredes eram de pedra, sem janelas e piso frio, o que condicionava a atmosfera do lugar.

Aos poucos, os membros do grupo começaram a se ambientar ao local e criar sua própria forma de ocupar o espaço. Brook propôs que utilizassem um tapete de seis metros quadrados no chão, rodeados de almofadas, para estabelecer a área de atuação e discussão. Naturalmente alguns membros achavam bastante incômoda e desconfortável essa posição de sentar-se ao chão para realizar todas as atividades do grupo, mas, segundo revela Oida (1999, p. 76), Peter Brook "dizia que não pode existir uma verdadeira comunicação quando se está sentado em volta de uma mesa".

O trabalho começava todos os dias precisamente às dez horas da manhã. Brook aplicava exercícios físicos, vocais e improvisação, bem como discutia problemas específicos e projetos futuros, com o objetivo de:

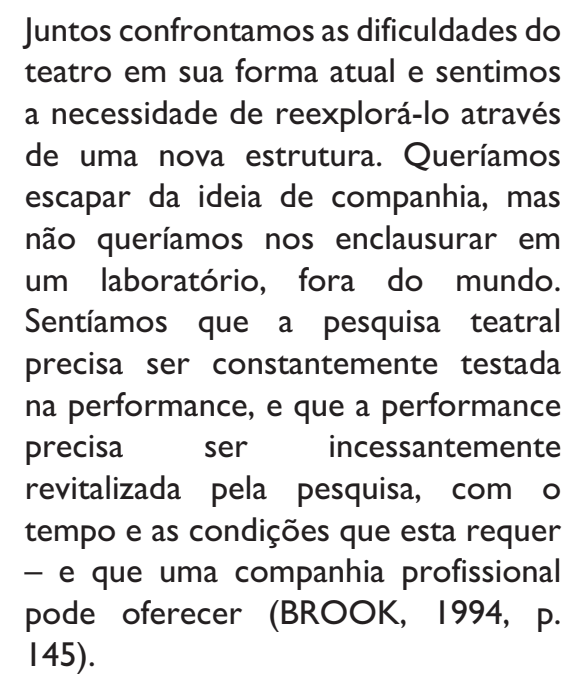

Neste primeiro momento Brook queria estabelecer um grupo estável, no qual seria possível experimentar a fusão entre culturas, temperamentos, estilos e origem dos membros do grupo em prol da universalidade de ideias. Desejava se libertar dos dogmas do teatro convencional da época, vinculado aos conselhos administrativos e aprisionados nos edifícios teatrais e seus palcos, o que engessava qualquer possibilidade de experimentação cênica.

Outro questionamento, quando se estabeleceram como grupo, era a ideia de que as palavras fossem os elementos mais importantes da expressão teatral. Deste modo, decidiram afastar os atores da palavra a 
fim de descobrirem distintas possibilidades. Acabaram por direcionar sua pesquisa em direção na produção não verbal. Algumas das temáticas mais frequentes, nos primeiros anos, foi o uso da voz e da linguagem. Como os atores nesse primeiro momento, não se conheciam e nem tinham familiaridade uns com os idiomas dos outros, concluíram que uma das possibilidades de comunicação seria por meio de movimentos corporais.

Evidentemente que cada montagem solicitava uma preparação corporal distinta. Porém, em relação aos trabalhos corporais com os atores, inicialmente optouse por exercitarem acrobacia, tai chi chuan, movimentos do teatro nô e kathakali. $O$ intuito do treinamento corporal era tornar a comunicação entre os atores mais ágil e, para tanto começaram utilizando bambus como forma de comunicação entre eles. Posteriormente, substituíram esse material por caixas de papelão, de modo a tornar mais flexível e reaproveitável as possibilidades de experimentação cênica.

Uma das justificativas para a alteração do material de experimentação dos atores foi indicada pelo diretor como a forma de estabelecer uma ligação entre o imaginário e o universo cotidiano. Para atingir a imaginação dos espectadores, Brook (2000) colocava como fundamental que seus atores se desprendessem de quaisquer hábitos e gestuais cotidianos, e estivessem concentrados e focados na mensagem pretendida. Vale ressaltar que, naquele momento da pesquisa, a base de exercício dos atores eram ações de improvisação. Essa prática se tornou frequente nas investigações da companhia, bem como o tapete se tornou a área de experimentação do ator. $O$ tapete era usado para os ensaios junto com a imaginação do ator, enquanto a caixa e os exercícios de improvisação eram fontes de pesquisa para estimular a imaginação da plateia.

Estes exercícios, mesmo que não fossem espetáculos acabados, geralmente envolviam a participação de público, uma vez que um dos pilares da pesquisa do Centro estava na relação entre o trabalho dos atores e a leitura dos espectadores. Para atingir significados mais poéticos, relacionados com o que Brook definiu como sagrado, trabalhava-se a ressignificação dos objetos (tanto do bastão de bambu, como da caixa de papelão), através da imaginação e da criação de situações em improvisações.

A primeira pesquisa, baseada nos processos de improvisação, deu origem a um espetáculo chamado Orghast (197I), texto do poeta Ted Hughes que tinha como temática de discussão a mitologia de Prometeu. O grupo decidiu expandir seus horizontes e estabelecer contato com novas culturas; deste modo, escolheu então, em 1972, explorar o Irã, antiga região da Pérsia, como primeiro local de visita internacional por se tratar exatamente da área onde as culturas orientais e 
ocidentais encontravam-se no período da Antiguidade. Fato que, segundo Brook (2000), propiciou um maior contato com as emoções.

Ao retornarem do Irã, naquele mesmo ano, estavam convictos de que seria fundamental para novas descobertas do grupo internacional, trabalharem em outros países a fim de aprofundar mais suas investigações sobre o teatro e sua relação com o público. Na segunda pesquisa, optaram por outros locais como a África, pois desejavam estabelecer contato com pessoas que nunca tivessem tido qualquer contato com teatro, tal qual exercido por Brook

Durante as investidas na África, Brook selecionou alguns trechos de textos para trabalhar com seus atores e o público: começou com Timon de Atenas e, mais adiante, passou a utilizar Medida por Medida, ambos de Shakespeare. Depois optou por textos quase anônimos, e foram adicionados aos seus textos iniciais: Os $1 \mathrm{ks}$, de Colin Turnbull; e Ubu-Rei de Alfred Jarry. Brook parecia sentir atração por textos em que a individualidade dava lugar a uma voz que ultrapassava os limites do ego. $O$ objetivo de Brook e sua companhia, naquele momento, não era de montar uma peça teatral, mas de estar aberto a um questionamento do ser humano no mundo. Vale destacar que, em alguns momentos, realizaram experimentos com fragmentos de $A$ Conferência dos Pássaros, tanto na viagem à África, como a que fizeram aos Estados Unidos.

Em 1974, quatro anos depois de se estabelecerem em Paris, Brook e os membros do Centro Internacional perceberam que era necessário ter um espaço permanente, no qual pudessem desenvolver o trabalho. Naquele mesmo ano, Micheline Rozan, produtora do grupo, sugeriu que visitassem um teatro abandonado que ficava atrás da estação Gare du Nord cujo proprietário tinha a intenção de demoli-lo para transformar a área em um estacionamento. O Théâtre des Bouffes du Nord, construído em 1874, permaneceu vazio desde 1952 até o estabelecimento do grupo teatral, tornou possível a realização uma série de experimentos. Foi com a conquista deste espaço que Brook pode aprofundar a pesquisa teatral inserindo diferentes tradições culturais em seus processos criativos e tornando-se pioneiro no que é considerado, atualmente, "multiculturalismo".

De posse de um espaço teatral adequado Brook começou a realizar no Bouffes du Nord uma série de espetáculos marcantes e importantes. A primeira montagem no retorno do grupo foi Timon de Atenas (1974), seguida por Os lks (1975), Ubu au Bouffes (1977) e, nesse mesmo ano, montou outros textos de um dos seus autores favoritos, Medida por Medida (1978) e Antônio e Cleópatra (1978). Com a montagem destes espetáculos Brook, finalmente, se sentiu seguro para começar experimentar colocar em cena temáticas 
vinculadas a sua evolução espiritual, como é o caso de A Conferência dos Pássaros (1979), espetáculo baseado num poema Sufi do século XII, que apresenta a essência do pensamento islâmico. Sendo sucedido pelo icônico O Jardim das Cerejeiras (198I) de Anton Tchekhov.

\subsection{AS ORIGENS DO TRABALHO E O TEMA DE A CONFERÊNCIA DOS PÁSSAROS}

Durante o trabalho exploratório do grupo na África e nos Estados Unidos, foram acrescidos, para atividades experimentais, trechos do texto $A$ Conferência dos Pássaros, também conhecido como $A$ Linguagem dos Pássaros - um texto do poeta persa, do século XII, Farid ud-Din Attar com cerca de 4500 versos. Trata-se de um poema épico, um tipo de narrativa alegórica, que apresenta a essência do pensamento sufi, sendo uma das mais importantes obras da literatura muçulmana acolhida por escritores como Cervantes, Dante e Jorge Luis Borges. Sua estrutura é simbólica e se projeta enquanto metáfora da busca pelo divino.

No texto há um eixo principal composto por histórias secundárias que complementam o enredo. As histórias, para os sufis, são possibilidades de transmitir as experiências vividas; desse modo, elas têm a função de servir como espelho para o desenvolvimento espiritual de seus seguidores. No oriente os mestres se aproveitam de histórias para a transmissão de ensinamentos aos seus discípulos. A Conferência dos Pássaros é exatamente uma dessas histórias com carácter especial, justamente por seu tamanho e complexidade.

O enredo conta que o rei dos pássaros, Simorgh - um pássaro da lenda da Pérsia, uma espécie de alegoria da busca pelo divino -, deixa cair no centro da China uma pluma esplêndida. Um grupo de pássaros, cansados de sua anarquia, se reúne para identificar quem deveria ser seu rei, uma vez que eles não têm nenhum. A Poupa, ou Boubela, considerada a mais sábia de todos, sugere que eles encontrassem o mitológico Simorgh. Um grupo de pássaros é guiado pela Poupa, decidem fazer a empreitada.

Eles sabem que a moradia de Simorgh está no monte Káf, que rodeia a Terra, e rumam em direção à fortaleza do pássaro divino. Atravessam o deserto e superam sete vales, que simbolizam as etapas de transformação da consciência e a encarnação do conhecimento e que representam as estações que um sufi, ou qualquer indivíduo, deve passar para perceber a verdadeira natureza de Deus: Talab (ânsia); Eshq (amor); Marifat (gnose); Istighnah (desapego); Tawhid (unidade de Deus); Hayrat (perplexidade); e, finalmente, Fuqur e Fana (abnegação e extinção). Durante a viagem, cada uma das aves que parte com a Poupa - representada como o mestre sufi -, desiste da jornada e somente trinta pássaros do grupo original conseguem chegar ao seu destino. Cada uma das aves desistentes representa 
uma falha que impede o homem de atingir a sua iluminação.

Além de ser um dos exemplos mais célebres da poesia persa, este livro se baseia em um jogo de palavras entre as palavras Simorgh e "si morgh" - que significa "trinta pássaros" em persa. O texto descreve, de modo metafórico,

[...] as etapas percorridas pelos pássaros-homens para atingir um estado desconhecido da consciência humana, e por isso colocado além da barreira das palavras e da mente [...] que levam o homem ao despojamento de ilusões, dos falsos e mundanos ideais (FARIA, 20I0, p. I03).

Finalmente os trinta pássaros purificados pelo trabalho, chegam à moradia de Simorgh, entregamse à meditação em busca da revelação do mistério da unidade e da pluralidade humana, e percebem que o Rei que buscavam, tinham encontrado em si mesmos. Essa conclusão reflete a doutrina sufi, que revela que Deus não é algo externo, ou que esteja separado do universo, e sim a totalidade da existência.

Em dezembro de 1972, um grupo de onze atores, juntamente com Brook, a compositora Elizabeth Swados, o percussionista africano Ayansola e o jornalista inglês John Heilpern realizaram uma viagem, com duração de cem dias, por cinco países da África Ocidental, iniciando pela Argélia. A jornada principiou em Argel e seguiu por uma rota descendo pelo deserto do Saara em direção à cidade de Cotonou em Benim (antigo Daomé), retornando à cidade de origem da viagem, passando novamente pelo deserto.

Esta segunda viagem proposta no projeto original de Brook e Rozan, segundo descrição feita pelo jornalista Heilpern (1978), foi, especialmente para os atores, um processo marcante de desconstrução de condicionamentos e de aprofundamento da pesquisa. Utilizavam bastante a técnica de improvisação dos carpet shows, para estabelecer contato com as diversas culturas africanas. Todos pareciam viver um embate bastante concreto com seus limites físicos, culturais, artísticos e psíquicos.

Todas as condições pareciam corroborar nessa desconstrução de padrões; o ambiente, a temperatura local, as condições de convívio do grupo, a cultura, a comida, as doenças e as exigência propostas pela direção. Nesse aspecto, a jornada do grupo se assemelhava bastante ao processo de descobrimento dos ensinamentos vivenciado por Gurdjieff e seus discípulos, nas diversas expedições que realizaram. E, a partir de sua vivência pessoal, o mestre de Brook descobriu que uma das formas de conseguir se tornar desperto é justamente através da desconstrução de padrões.

De acordo com as questões supramencionadas, para 
estabelecer contato com a população local durante a viagem, um dos trechos escolhidos para o trabalho foi justamente parte da epopeia A Conferência dos Pássaros, cujo projeto final seria chegar a um espetáculo. Conforme descreveu Brook (1994, p. 205), o texto "se constitui num trabalho de níveis e facetas ilimitadas para nós, representou o oceano de que precisávamos. Aproximamo-nos dele cautelosamente, passo a passo".

Nesta primeira proposta, Brook e Swados haviam selecionado alguns trechos e pedido que $\circ$ autor Ted Hughes, que já havia trabalhado com o grupo em Orghast, fizesse a adaptação, em Paris. Contudo, o material apresentado não foi condizente com as expectativas do diretor. $O$ texto produzido por Hughes tinha uma carga bastante densa e subjetiva, enquanto Brook preferia que o enfoque fosse relacionado à graciosidade e brincadeira, uma vez que iriam explorar o contexto sem muitos recursos, mais voltados então às características do teatro rústico descrito por Brook (2008) em $O$ espaço vazio. Os trechos deveriam ser, portanto mais cômicos, alegres, cadenciados e repletos de vitalidade.

Esse primeiro trabalho com o texto não estava focado no caráter místico do poema, nem nas características do ensinamento espiritual, era uma abordagem prosaica e ligeira, que se ajustava bastante à proposta do grupo. Naquela ocasião, o objetivo era explorar o teatro de improviso e o relacionamento com outras culturas, de modo que se estabelecesse um contato cultural e houvesse uma troca de energia por meio da ação teatral. Enquanto explorava a cultura local, o grupo percebeu que havia uma grande vitalidade - vocal e corporal -, quanto uma capacidade de foco e atenção, que permitiu uma troca bastante intensa e rica para a pesquisa que pretendiam realizar.

Contudo, para a montagem do espetáculo, em 1979, Brook propôs que houvesse uma adaptação diferente para o texto e o responsável por esse trabalho foi - escritor francês Jean-Claude Carrière, o antigo roteirista de Buñuel. O escritor se integrou ao grupo em 1974, quando ocuparam o Théâtre des Bouffes du Nord. Naquela época, ficou responsável pela tradução, para o francês, do texto Timão de Atenas. Durante os cinco anos seguintes, até a estreia do espetáculo $A$ Conferência dos Pássaros, o texto era recorrentemente trabalhado como exercício para os atores.

No decorrer desses anos, o escritor pôde experimentar diversas etapas e possibilidades a partir do poema sufi. Quando decidiram realizar a montagem do texto, Brook questionou se seria possível que Carrière desenvolvesse a adaptação do texto e escrevesse uma peça com base em A Linguagem dos Pássaros, em cinco meses de ensaio. $O$ objetivo, agora, era escrever um roteiro que contasse a história de forma mais completa, 
indicando as principais ideias do texto original e não só fragmentos como ocorreram nos exercícios anteriores. Depois de dois meses o escritor entregou sua primeira versão para que o grupo pudesse trabalhar.

Desde que começou a trabalhar com experimentos teatrais, já na Royal Shakespeare Company com U.S. por exemplo, Brook (1994, p. 208) identificou a necessidade de trabalhar sempre junto a um escritor, "um especialista, um homem das palavras", com o intuito de enriquecer a expressão dos textos de suas montagens. Contudo, assim como os demais profissionais envolvidos no processo, o autor também deveria estar permeável às mudanças decorrentes do processo de criação do espetáculo teatral, trabalhando juntamente com o processo de evolução dos atores.

As cenas escritas eram verificadas e testadas por meio de improvisações até que se ajustassem e estivessem próximas ao formato mais adequado às necessidades do espetáculo. Sempre que o texto estivesse esboçado, era colocado para que os atores o improvisassem. Assim Carrière assistia $\circ$ trabalho dos atores seguido pelas intervenções propostas por Brook e, sequencialmente, os trechos expostos eram reestruturados e reescritos por meio desta interação.

O texto final seguiu a narrativa geral do texto de Attar, ressaltando seu aspecto mais dinâmico. Dessa maneira a peça também se estruturou em cinco grandes partes, como o texto original, a saber: $O$ Início da Conferência; As últimas desculpas; No deserto; Os Sete Vales; e $O$ Simorgh. A principal ideia de Brook e Carrière, para a montagem do espetáculo, era que a ação ocorresse na viagem que realizavam em direção a Simorgh e não na assembleia dos pássaros como está no texto original, em que a viagem somente é relatada na parte final do texto.

No livro a maior parte das situações é justamente resultado da conferência, da discussão entre os pássaros; enquanto, no espetáculo, a conferência ocorre no início, nas duas primeiras cenas e, a partir de então, inicia-se a viagem. É relevante destacar que Carrière acrescentou algumas histórias e encontros com personagens em todo o percurso da viagem, ou seja, durante a travessia do grupo pelo deserto e pelos sete vales até a chegada à morada do Simorgh.

Nestas histórias, surgiram algumas personagens humanas, representadas por reis, princesas, escravos, ladrões, viajantes e, também, de um santo sufi. $\mathrm{Na}$ construção do texto foram colocadas estas histórias para que dialogassem diretamente com as questões com as quais os pássaros se deparam. As respostas, assim, são evidenciadas por meio de parábolas e respondem, de maneira indireta, aos questionamentos expostos anteriormente. Ao incluir a questão simbólica na estrutura da narrativa pretendida, houve uma 
preocupação em tornar o texto original mais universal, de modo a não sobrecarregar a apresentação com uma carga de tradição islâmica que não era pretendida pelo grupo.

Carrièrre fez uma síntese bastante elaborada das histórias apresentadas no poema original, bem como das personagens-pássaros. A diversidade de pássaros, existentes no texto, indica os diferentes tipos sociais que se demonstram a partir das diferenças de comportamento e caráter. O Pardal, por exemplo, por ser sensível e pequeno, utiliza a desculpa de ser frágil para não realizar a viagem, pois acredita que não conseguiria completá-la. O Falcão, que representa um guerreiro leal e orgulhoso, não enxerga sentido em realizar uma viagem tão complexa para encontrar um rei legítimo, uma vez que ele já serve a um.

A Poupa, responsável por narrar a história, delineia, por sua vez, tanto para os pássaros como para o público, qual é o real significado da jornada. Ir ao encontro do Simorgh significa simplesmente "entrar" e "perder tudo", de modo a se tornar "livre" - da tirania e da escravidão - e, realizar completamente todas as potencialidades humanas, abrindo mão das ilusões sobre o mundo e sobre si mesmo, para se conectar com o conhecimento verdadeiro e com a plenitude do Amor "que não morre", Deus.

Dessa maneira a peça, que se divide em dois momentos - o primeiro, antes da partida dos pássaros; e, o segundo, durante a viagem até a morada do Simorgh, é um pedido para que cada um reconheça sua situação "limitada" e receba o desafio de transformar a si mesmo e o seu posicionamento diante do mistério da existência.

\subsection{A CRIAÇÃO DE A CONFERÊNCIA DOS PÁSSAROS (1979)}

O espetáculo A Conferência dos Pássaros começou com as experimentações de Brook e sua Companhia durante as viagens à África no ano de 1972. Naquele momento a versão improvisada foi sugerida pela direção de Brook em conjunto com a escritora e compositora Elizabeth Swados. Eram de seis a oito histórias relatadas no poema, mas que tinham como fator de dificuldade ser uma improvisação musical e não-verbal. O tema de Attar estava presente embora não houvesse, nessa primeira investida, uma personagem que liderasse a expedição.

Além dos textos que serviam para improvisações, os exercícios com a "linguagem dos pássaros" eram contínuos. A começar pela trama da história, que ocorre com a travessia do grupo de pássaros pelo deserto, enquanto Brook e a companhia estavam, literalmente, atravessando o deserto do Saara nessa expedição à África. Depois, quando estavam acampados em lugares com arborização e presença abundante de pássaros, os atores aproveitavam para exercer a escuta e observação dos animais para que, em seguida, pudessem 
se expressar imitando as posições, movimentos, e sons com os cantos e arrulhos.

O jornalista que acompanhou o grupo, John Heilpern, registrou a viagem no livro $A$ Conferência dos Pássaros (1978) e relatou que, num momento da viagem, havia uma série de experimentações com pássaros realizadas nos carpet shows propostos. Os atores realizavam as apresentações com bastões e canções, desenvolvendo um excelente trabalho musical. Havia muitos pássaros: "pássaros viajando, pássaros em busca, pássaros perdidos, pássaros se afogando, pássaros lutando para sobreviver. $O$ trabalho estava evoluindo para uma nova tentativa com a grande peça, A Conferência dos Pássaros" (HEILPERN, 1978, p. 223). Em seguida, Heilpern descreveu em seus relatos o comentário do ator Lou Zeldis, que comentou: "Sabe, está ficando realmente irritante não ser capaz de voar" (HEILPERN, 1978, p. 223).

O produto destas experiências originou distintas encenações que resultavam diretamente, na necessidade da comunicação com o público. Desse modo, Brook realizou que seu conteúdo era verdadeiramente universal, pois havia passado sem impedimentos através de todas as barreiras culturais e sociais. Segundo o ator Bruce Myers (apud BANU, 1982, p. 255), "Era uma versão primitiva de $A$ Conferência dos Pássaros. Uma versão um tanto quanto mística. Apenas uma história”.
Porém permitiu que o grupo se apropriasse, de modo bastante contundente, da temática abordada pelo texto. Com o material realizaram improvisações livres e pesquisaram sobre as personagens-tipo, próximos aos desenvolvidos no texto.

Algum tempo depois da imersão nas cidades africanas, em 1973, uma nova plataforma de trabalho do Centro Internacional de Pesquisa Teatral permitiu outra experiência bastante peculiar e viva, diante de um público completamente distinto do anterior. Trata-se da viagem que fizeram para os Estados Unidos que fazia parte do planejamento do grupo.

Começaram seu percurso pelas grandes fazendas da Califórnia, esperavam encontrar um processo semelhante aos vilarejos africanos. Contudo a realidade que encontraram era bastante diferente da sua expectativa, pois se depararam com muitos mexicanos que já estavam inseridos no processo de industrialização. Ou seja, se descobriram uma cena bastante urbana, mesmo quando se encontravam com espaços amplos e abertos nessas regiões de produção agrícola. $O$ final dessa jornada ocorreu em Nova lorque, na região do Brooklyn, na BAM (Brooklyn Academy of Music), onde permaneceram por três semanas, entre setembro e outubro de 1973.

Ali $\circ$ grupo ocupou o salão de baile e realizou uma série de encontros com artistas da região, seguindo 
um programa que se chamou: "Dias de Teatro". Desenvolviam exercícios pela manhã, improvisações à tarde e, à noite, sessões de trechos de $A$ Conferência dos Pássaros para alguns espectadores. Durante estes encontros Brook e sua companhia puderam fazer novos experimentos com o texto do poema sufi. Ao final desse período, realizaram três apresentações completamente distintas, com três diferentes grupos de pessoas, cada um deles liderados por um grupo de atores e membros da companhia.

Yoshi Oida e Michelle Collison ficaram responsáveis pela apresentação às seis e às oito da noite, nas quais Brook disse usar elementos do "teatro rústico". Com uma energia bastante intensa, essa montagem posteriormente serviu de inspiração para criação do espetáculo Ubu aux Bouffes $^{\prime 2}$. Natasha Parry e Bruce Myers fizeram a versão da meia-noite, profunda, sussurrada e à luz de velas. Seu resultado era evidentemente mais sensível, ou seja, mais próximo do que Brook define como teatro "sagrado". E, finalmente, a compositora Elisabeth Swados fez a

${ }^{12}$ Ubu aux Bouffes que estreou em 1977 no Thêátre des Bouffes du Nord, é a versão desenvolvida pela CICT para o espetáculo Ubu-Rei de Alfred Jarry (I897- 1907), um espetáculo que é considerado um grandioso guignol pósshakespeariano estridente, improvisado, baseado na peça contundente do terrível infante do teatro francês. Nessa versão, Brook queria restaurar a violência cômica e a vulgaridade que Jarry coloca em seu texto, estabelecendo raízes com a escrita do cômico grego de Aristófanes. No espetáculo Ubu e sua esposa Mãe-Ubu decidem que podem se tornar rei e rainha de uma Polônia imaginária. Eles trapaceiam e intimidam todos que estão no seu caminho ao topo, deixando a Europa repleta de cadáveres. Seu jogo de poder, sem nenhuma crença ou valor interiores, atingiu bastante a plateia da época pela familiaridade com os tiranos da história contemporânea. atuação da madrugada, de modo totalmente ritualístico e musical. Brook identificou que o resultado desse workshop poderia ser incorporado a um de seus espetáculos.

Alguns anos mais tarde, já em 1979, decidiram realizar a montagem do espetáculo $A$ Conferência dos Pássaros inspirado no poema de Attar, adaptado para o inglês por Brook e atualizado para o francês por JeanClaude Carrière. $O$ trabalho, naquele ano, sugeriu um novo caminho, deixando o artifício teatral para trás. Estavam preocupados com o que o diretor chamou de “o essencial”, ou seja, o despojamento de apetrechos desnecessários à encenação. Seu esforço concentrou-se em atingir uma nova simplicidade, de modo a alcançar uma "unidade" entre os seguintes elementos de cena: atores, audiência e tema abordado pelo autor. Assim, após novo período de ensaios, o espetáculo foi exibido no festival de Avignon junto com outro espetáculo L'Os, no verão de 1980, e realizou turnê mundial depois de uma temporada no Théâtre des Bouffes du Nord.

Vale ressaltar que $A$ Conferência dos Pássaros sempre foi exibida em conjunto com a farsa L'Os (Os ossos) e nunca apresentada independentemente dela. Tanto que Georges Banu (1982) sugere que essa configuração, proposta por Brook, se assemelha bastante com as formas de teatro tradicional, ou seja, do costume da tragédia grega vir sempre acompanhada pelas 
saturnais, ou do teatro Nô seguido pelo Kyôgen. Caso A Conferência dos Pássaros fosse apresentada sem o espetáculo anterior, poderia parecer um espetáculo totalizante sobre a busca humana. Assim, de maneira a suavizar o discurso essencialista, o diretor optou por equilibrar seu discurso com uma farsa rápida.

Também é significativo salientar que Brook estava pesquisando, naquele momento, uma forma de integrar suas definições sobre o teatro rústico e sagrado. De modo que a montagem de L'Os ficou responsável pelo desenvolvimento do elemento rústico do espetáculo. Sua trama revelava um mundo material imperfeito que serviria para, na sequência, indicar a viagem dos pássaros em busca de seu aprimoramento espiritual. De tal modo, além de aproximar o público de um contexto mais cotidiano, a farsa evidenciava a busca do ser humano pela transcendência e pela sua evolução moral e espiritual.

A farsa L'Os é baseada no texto do escritor africano Birago Diop. O texto é resultado de sua investigação sobre a cultura oral do Senegal e foi publicado no livro Les nouveaux contes d'Amadou Koumba em 1958. Em seguida o autor decidiu transformar $\circ$ texto em espetáculo que foi representado pela primeira vez, em 1966, no Senegal. Na versão de Brook a peça também teve adaptação de Jean-Claude Carrière e tinha duração de quarenta minutos.

148
A história toda se passava em uma pequena aldeia senegalesa em que um camponês avarento, Mor Lam preferia morrer do que partilhar seu robusto pernil de carne com seu companheiro. $\bigcirc$ protagonista, para não dividir o osso com seu colega, finge estar doente, na esperança de seu colega deixe sua casa. Percebendo que a ação não obteve sucesso, decide então fingir-se de morto. Infelizmente não obtém nenhuma vantagem pois, no final do espetáculo, todos acreditam e Mor Lam é enterrado vivo, enquanto seu colega termina saboreando um delicioso pernil e consola sua esposa, que agora tornara-se viúva, desposando-a em virtude da longa amizade que tiveram.

Para Brook (apud BANU, 1982), a estrutura estabelecida pelos dois espetáculos, um em seguida do outro, era fundamental, pois assim L'Os preparava os espectadores, sobretudo os mais céticos, a aceitarem os temas mais místicos que iriam ser evidenciados ao longo dos 75 minutos da montagem de $A$ Conferência dos Pássaros.
Ela ajudava a estabelecer um clima de simplicidade e confiança que tornava então possível conduzir o público à poesia mais rarefeita de uma obra sufi, sem que ele sentisse o tom esotérico como solene ou intimidativo (BROOK, 2000, p. 287).

O cenário de L'Os retrata o ambiente da aldeia africana. Brook optou por desenvolver o espetáculo com a menor quantidade de elementos possíveis, visando explorar a questão do espaço vazio. Para a composição 
Figura 26 - Cenário de L’Os, evidenciando a paliçada ao fundo e a utilização de estruturas simples para definir os espaços.

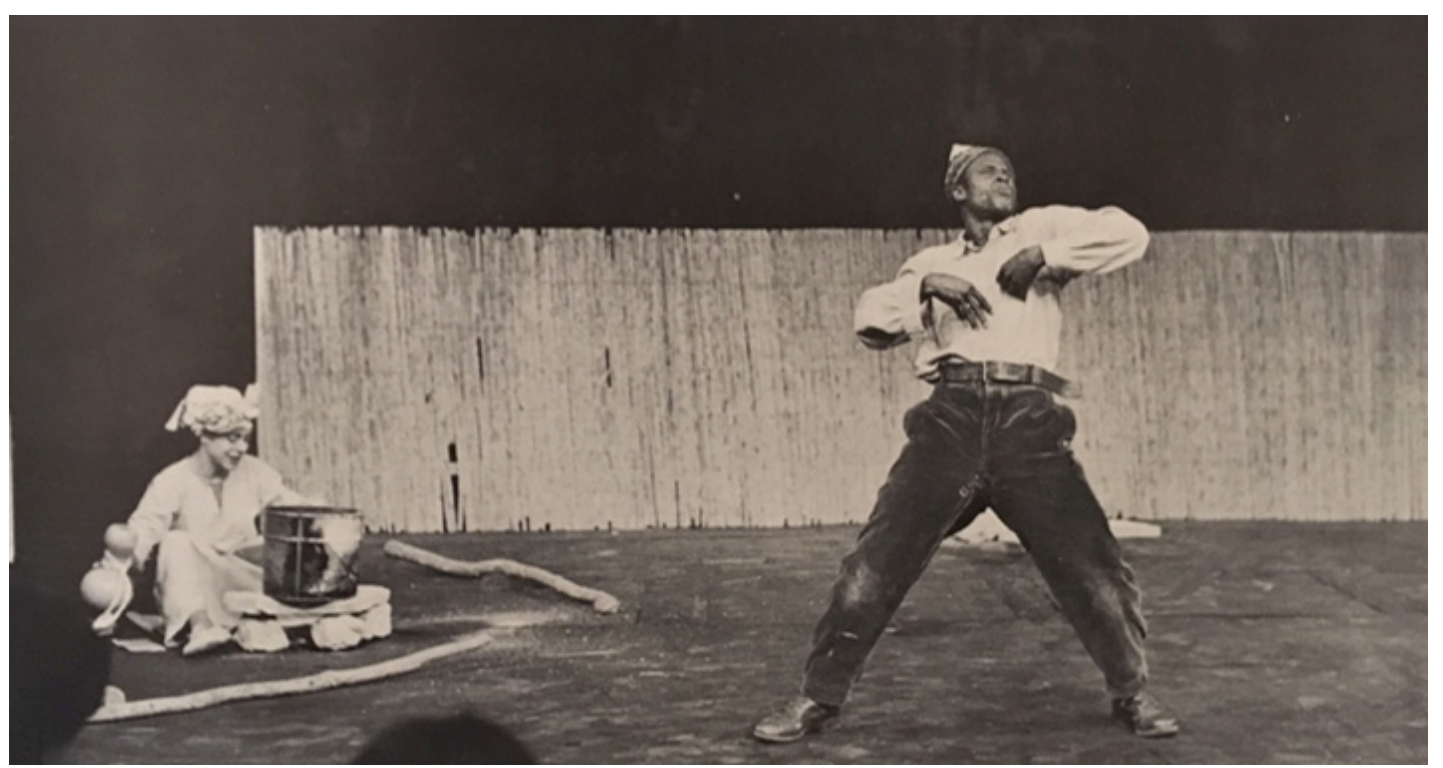

Fonte: Banu (1982, p. 259).

de cena utilizava utensílios como: pedaços de madeira, panelas, pedras e vasilhas, para diferenciar os ambientes internos da casa de Mor Lam (figura 26). Existia, também ao fundo, uma estrutura composta por uma paliçada que separava o ambiente interior e o exterior, indicando que o restante do ambiente seria a vila.

Essa opção de proposta de cena indica que há uma tentativa de fazer com que os espectadores, em relação ao espaço cênico, utilizem a sua imaginação para complementar as informações espaciais, mesmo que ainda tenham utilizado elementos reais do cotidiano para estabelecer o jogo cênico. Vale ressaltar, também, que para este espetáculo, Brook optou por realizar toda farsa na parte do semicírculo frontal justamente para ter uma maior aproximação e conquistar os espectadores.

Para os trajes de cena existia uma preocupação em que se assemelhassem aos trajes cotidianos da população de uma aldeia da região do Senegal, de onde provinha a história. Sendo assim, na proposta da farsa, Brook ficou próximo de uma reconstrução de trajes realistas para a configuração do espetáculo. Para trazer a referência africana os atores cobriam-se com tecidos coloridos, alguns utilizavam túnicas, amarravam tecidos na cabeça para se aproximarem dos turbantes bastante encontrados na região (figura 27). 
Figura 27 - Trajes de cena do espetáculo L'Os composição mais próxima de remeter ao cotidiano da população local.

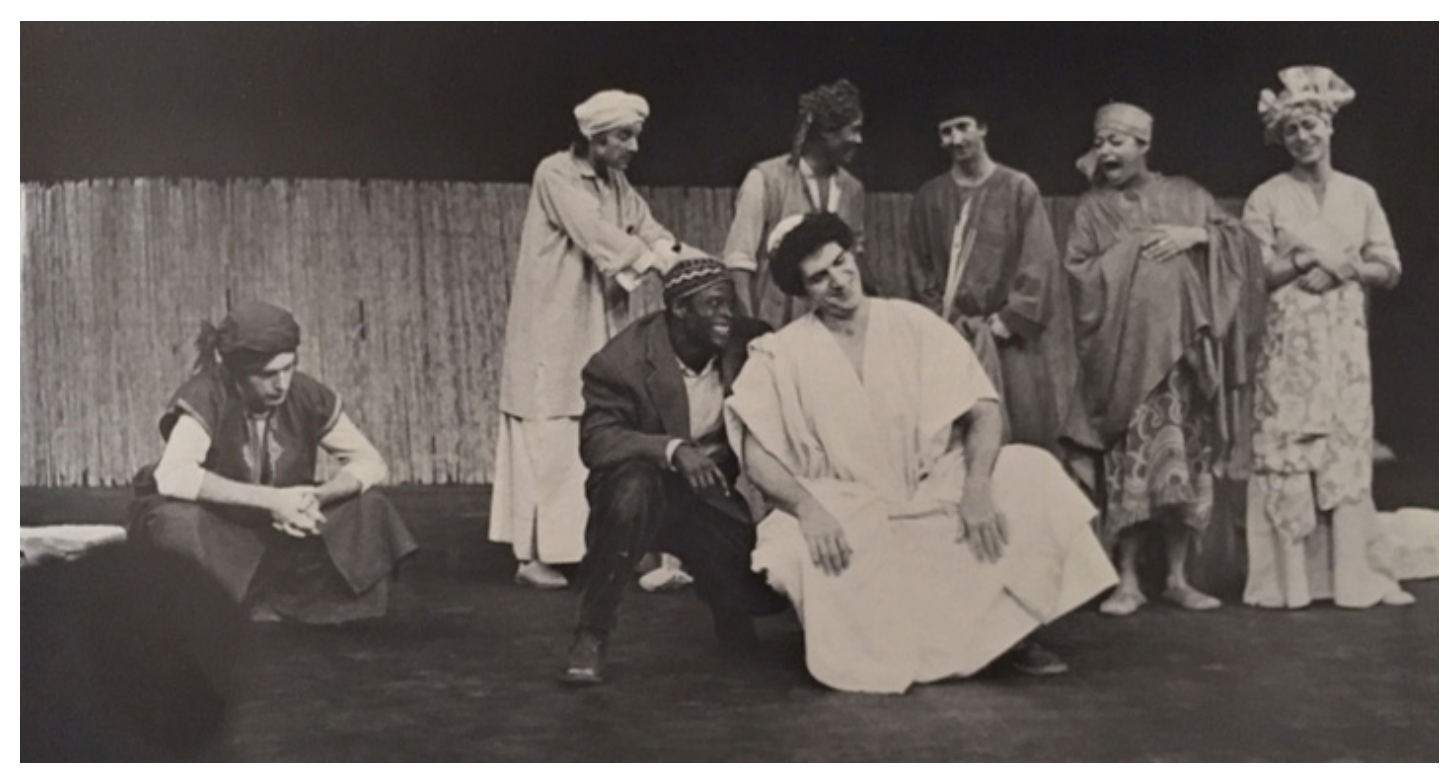

Fonte: Banu (1982, p. 259).

De forma a reforçar o recurso cômico, os atores em alguns momentos falavam o texto em dois idiomas, o francês e o inglês, evidenciando que se tratava de uma provocação ao entendimento da plateia. Reforçando que o mais importante era o envolvimento com $\circ$ jogo estabelecido pela atuação do que propriamente a compreensão das palavras do texto. Em A Conferência dos Pássaros, devido à importância dos argumentos, não ocorria a mesma situação: ou a peça era completamente apresentada em inglês ou francês.

O trabalho sobre a montagem do espetáculo $A$
Conferência dos Pássaros (figura 28) já havia se iniciado sete anos antes da sua efetivação de 1979. A preparação dos atores, do núcleo do grupo inicial, já havia começado na expedição africana. Ali, além de vivenciarem a atravessia do deserto, também tiveram a oportunidade de deixar guardada em suas memórias a pesquisa em relação aos movimentos e aos sons dos pássaros que estabeleceram contato pelas aldeias que passaram. Além desse resgate, Brook também pretendia que os atores tivessem uma atenção especial sobre o vazio para criar formas de modo a construir uma relação com os espectadores. 
Figura 28 - Cartaz do espetáculo A Conferência dos Pássaros (1979).

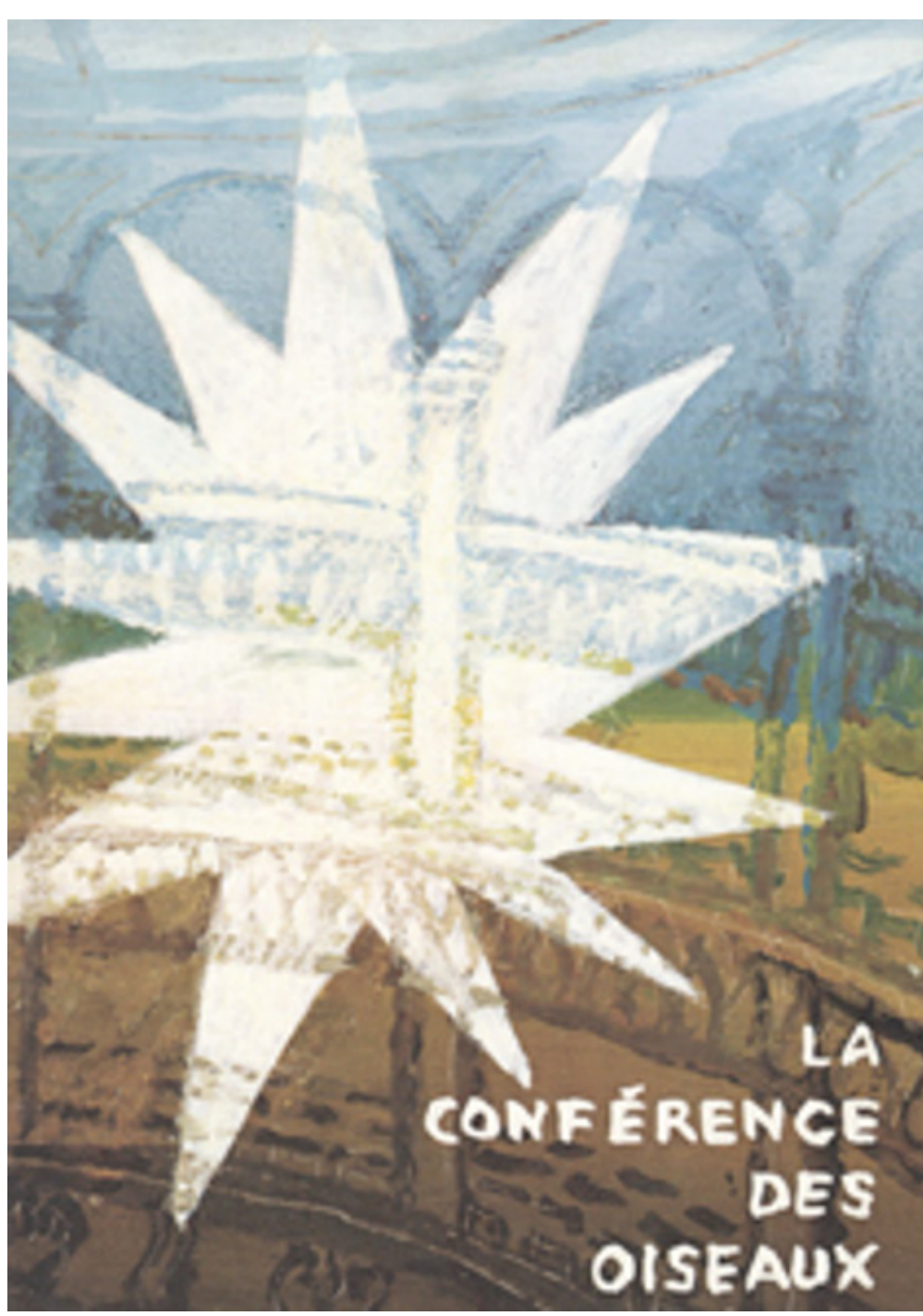

Fonte: Brook (1979). 
Como o texto não é realista, optou-se por utilizar a questão da narrativa como forma de condução dos espectadores pelas tramas da peça que tratava, de forma alegórica, sobre seres humanos em busca do seu aprimoramento espiritual. Havia também a intenção de se estabelecer um trabalho rítmico que configurasse uma conexão entre todos os atores criando, uma forte sincronia durante a peça. Não importava se a cena era realizada por alguns personagens, todos os atores estavam presentes de forma ativa e participavam da encenação de alguma forma.

Este processo era resultado da pesquisa estabelecida pela companhia durante os carpet shows em que, desde o momento em que o ator adentrasse o campo de representação, deveria permanecer, constantemente, atuante para estabelecer um jogo cênico com os demais. Durante a concepção do espetáculo, a partir das improvisações entre os atores, ainda propuseram que algumas histórias, as que mais os haviam tocado, fossem incluídas na peça.

Relacionado propriamente aos ensaios, Bruce Myers, em entrevista a George Banu em 1985, relata brevemente como foi o processo de montagem:

A primeira leitura é muito importante.

É a primeira escuta. Neste dia

a atmosfera é sempre especial, concentrada. Algumas vezes há quem encontre seu personagem neste momento. A gente lê durante praticamente duas semanas. Leituras em um ritmo contínuo, sem pausas, com calma.

Em seguida passamos às improvisações sobre os principais temas do espetáculo. Isso nos faz descobrir o texto. Se fala pouco, por outro lado experimentamos fisicamente muitas respostas possíveis. $\bigcirc$ que é importante são os temas que estão por trás, o fato de que estejam claros e precisos. Depois, a montagem do espetáculo se faz bem tardiamente. Brook começa este trabalho bem mais tarde que outros diretores. (MYERS apud BANU, 1985, p. 365).

Devido à estruturação do texto, os atores realizaram o espetáculo utilizando-se essencialmente da narrativa como forma para a elaboração das personagens que eram desenvolvidas de modo a dar vida aos acontecimentos relatados. Brook optou por estabelecer uma alternância entre a narração e a interpretação em primeira pessoa.

Desse modo fizeram uso de marionetes e fantoches que permitiam a inversão de situações durante o decorrer do texto. De maneira a humanizar e aproximar os espectadores da ação, decidiram não estabelecer um uso constante desses elementos, permitindo lançar informações suficientes para que a imaginação dos espectadores fosse estimulada e pudesse corroborar com a encenação.

A peça, cuja mensagem tratava da luta por alcançar 
uma maior consciência e conhecimento, combinava os vários estilos que a companhia trabalhou ao longo dos anos. Era essencialmente mística, mas, sob a direção de Brook, apresentava elementos alegres e, também, farsescos. Nestes seis anos, desde que os primeiros fragmentos foram exibidos ao público, o espetáculo foi totalmente remodelado em uma produção que contou com desenho de cenários e figurinos elaborados por Sally Jacobs (figura 29).
Apresentada em um palco com cenografia bastante reduzida, que contava com tapetes orientais pendurados nos fundos do palco, os atores assumiram vários papéis. Às vezes eles eram os pássaros: um falcão orgulhoso, uma pomba melancólica, um pavão arrogante, entre outros; enquanto que em outros momentos eles encenavam vários outros personagens da história, dentro do enredo contado pelo narrador. Brook também empregou no espetáculo fantoches de aves e máscaras balinesas.

Figura 29 - Figurino do pássaro exótico 2 para A Conferência dos Pássaros desenhado por Sally Jacobs para o ator Yoshi Oida.

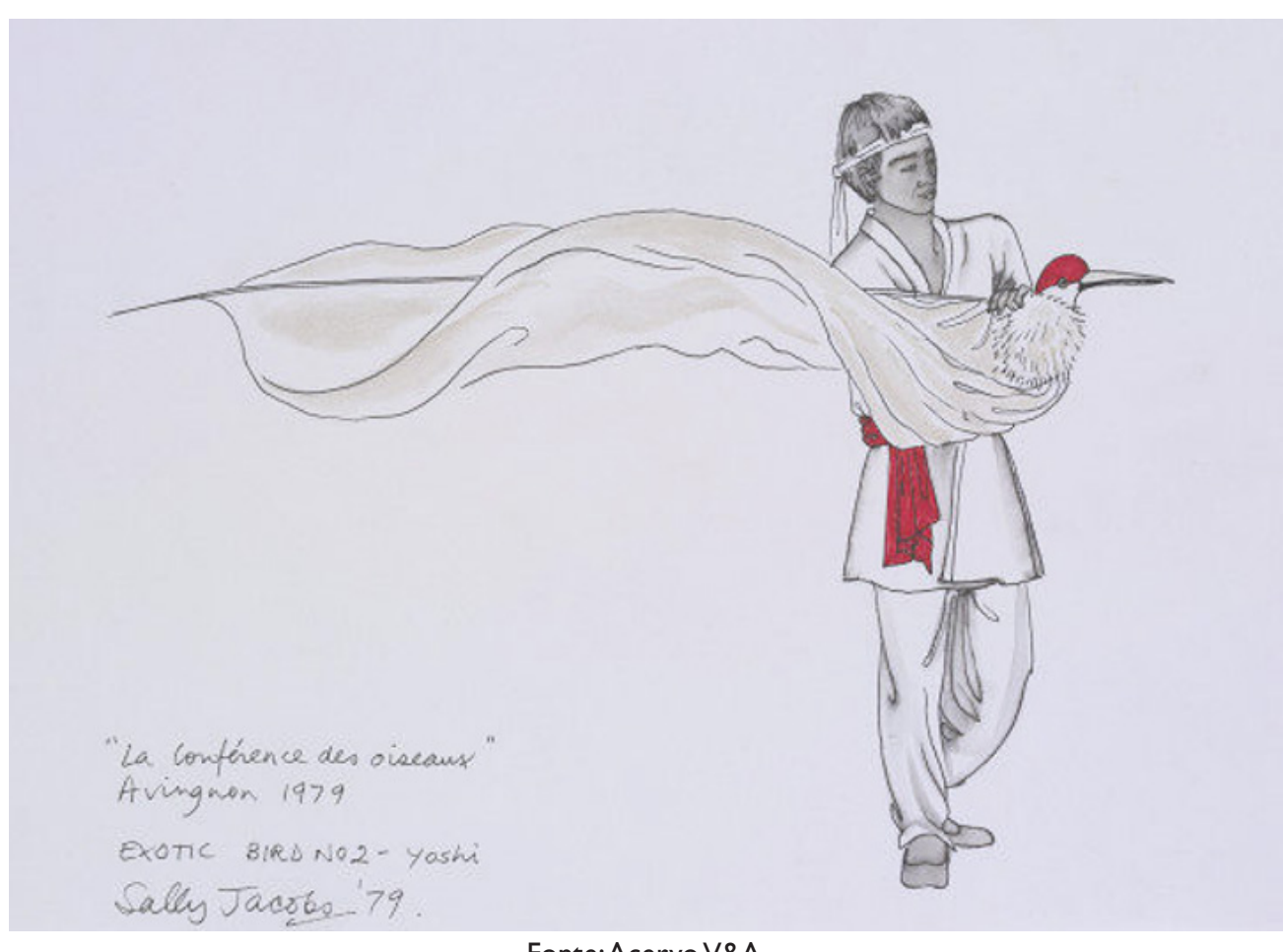

Fonte:Acervo V\&A. 
Para identificação das personagens, os atores se utilizavam de gestos em cena. Assim, um movimento de mão, uma volta da cabeça, um dedo arqueado sugeria algumas características do pássaro representado, e o restante deveria ser preenchido pela imaginação do público (figura 30). Além disso, havia uma variedade de músicas orientais e ocidentais esotéricas produzidas com gongos, tambores e com cantos de pássaros. $O$ diálogo, como no conto de fadas de uma criança, tinha sido reduzido ao essencial.
Brook relatou em entrevista a Coryden (1980) que, durante a sua experiência na África, aprendeu que a narrativa é a grande salvação do espetáculo teatral. Naquele continente puderam experimentar as situações mais adversas possíveis e identificaram que não há nada mais poderoso do que a história e, por isso, afirmou que seus atores são essencialmente contadores de histórias. A sua pesquisa, a partir de então, passou a ser orientada no sentido de priorizar o diálogo ator-plateia, ou seja, os atores não podiam se esquecer em nenhum instante da existência do público.

Figura 30 - Ator manipulando a Poupa no espetáculo A Conferência dos Pássaros (1979).

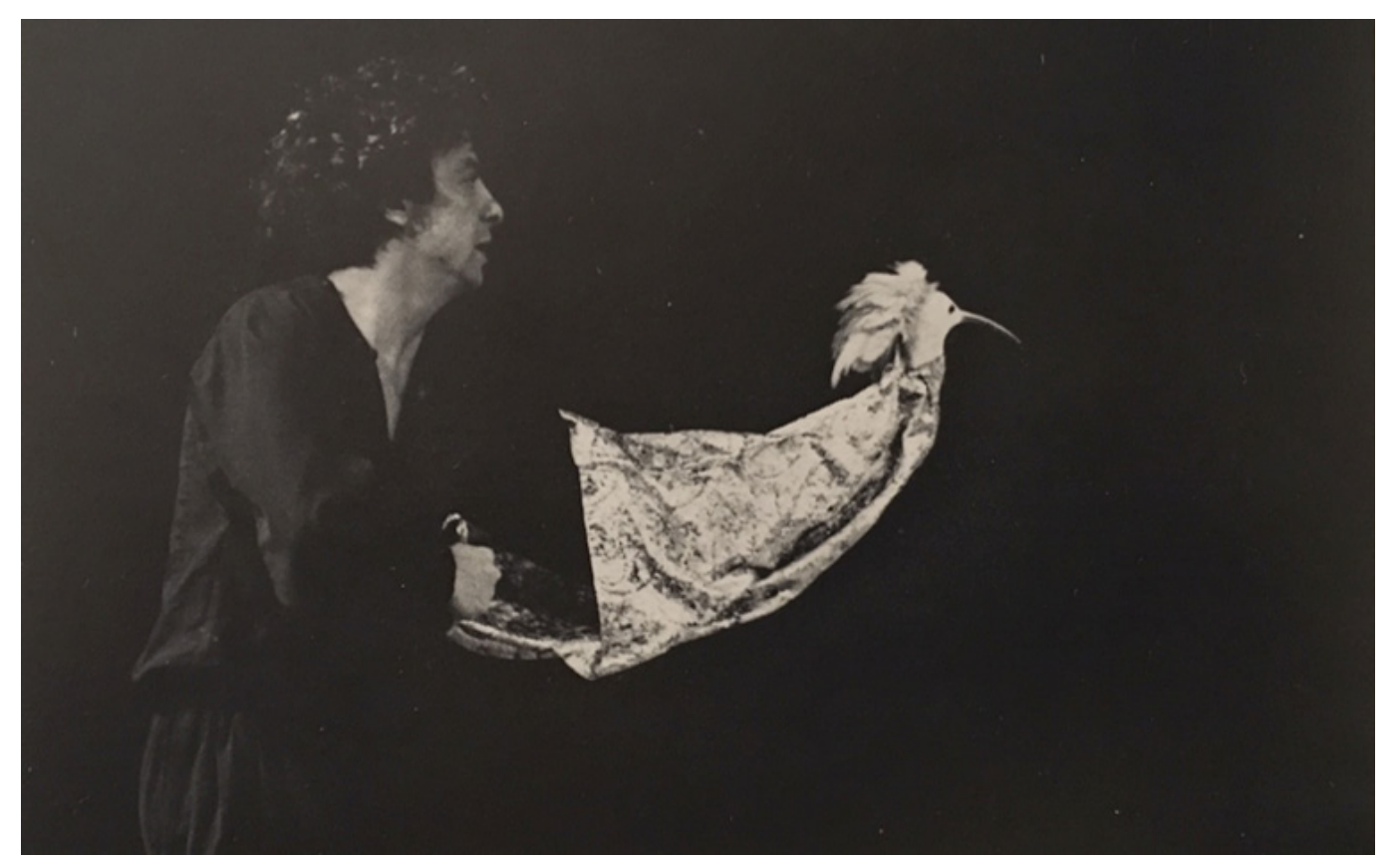

Fonte: Banu (1982, p. 262). 
A Conferência dos Pássaros não é um espetáculo realista e nem é algo completamente abstrato. É essencialmente um texto sobre os seres humanos e possibilidades humanas, por isso Brook decidiu expor um grupo de atores contando uma história para as pessoas de seu próprio mundo. Dentro disso os atores se tornaram indivíduos mais ou menos proeminentes. Seus rostos estão em alguns momentos perto, em outros longe da plateia, ou desaparecem completamente. Ora seus rostos são substituídos por máscaras (figura 31). Ora o olhar do público é conduzido inteiramente para fora dos rostos e dirigidos para um dedo, ou para um pássaro-fantoche. Todos são elementos da narrativa. $\mathrm{E}$ os atores sabiam que não se podia tirar qualquer um desses elementos sem prejudicar a narrativa da história.

De acordo com Brook, em Conversations with Peter Brook (CROYDEN, 2003), neste enredo existiam duas imagens básicas: um pássaro e um vale, representações bastante concretas. Havia, ainda, significados escondidos, tais como o poético e espiritual, por exemplo, e distintos níveis de expressividade. Para reforçar a sua forma de expressão ressaltava que, se o pássaro não estava

Figura 3 I - Cena com ator com máscara balinesa.

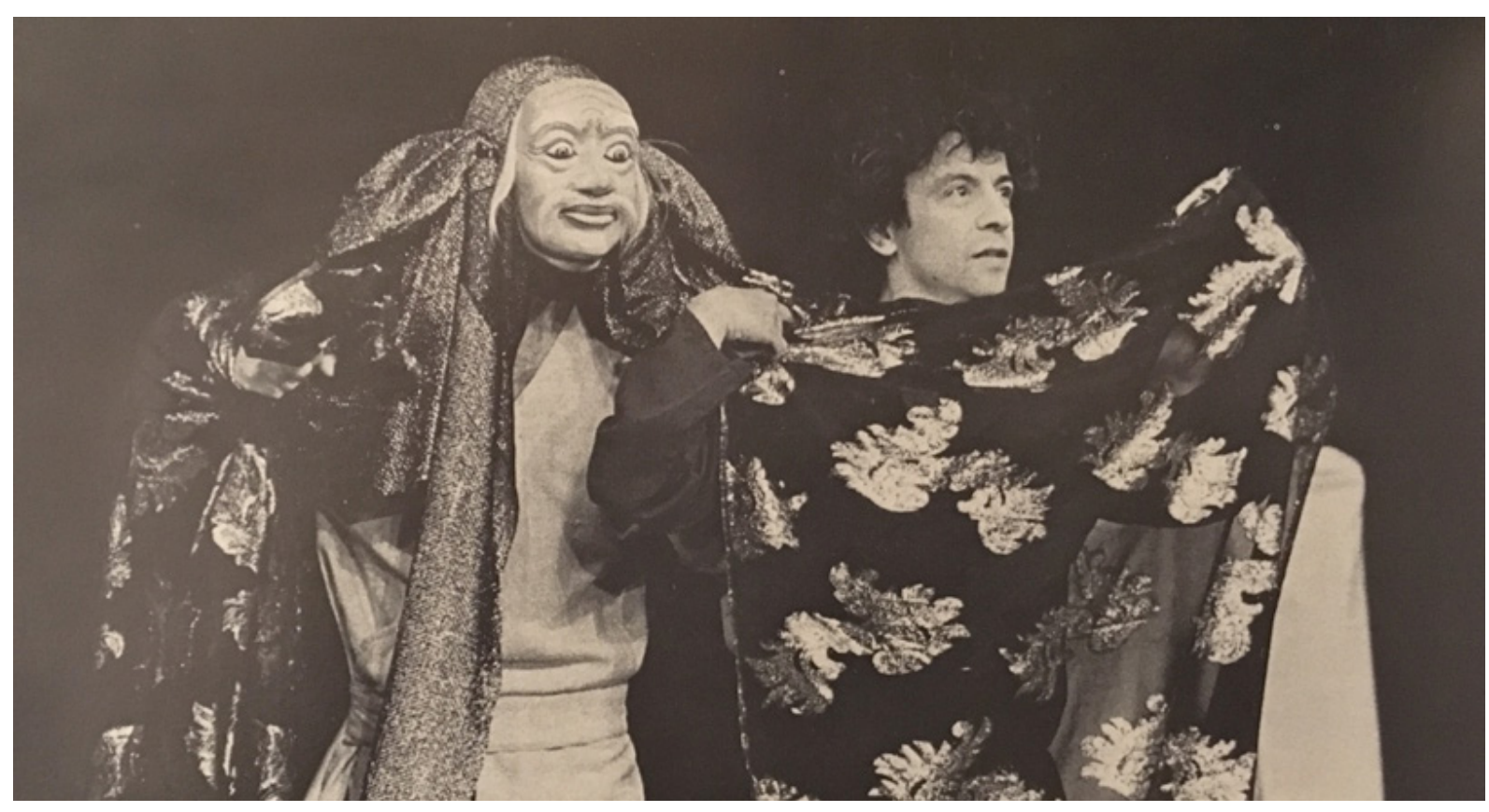

Fonte: Banu (1982, p. 272) 
em cena de qualquer modo, o poder evocativo desse símbolo poderia não chegar até a plateia. Se um pássaro se tornasse muito parecido com um pássaro realista, o significado espiritual era perdido.

Segundo seus relatos, para cada momento era necessária uma solução de representação distinta. Em uma situação o pássaro é uma cabeça. Em seguida está em voo e é sugerido pela energia efetiva e sensação de voo. Deste modo os atores foram treinados, especialmente, para transitar de uma situação a outra. E decidiram utilizar a sugestão ao invés da ilustração. "Sugestão" significa evocar da forma mais sutil possível, de modo que a impressão é forte mas os sentimentos são leves. E, nesse caso, a imaginação preenche o restante.

Vale ressaltar, também, que se trata de um momento especial pois é justamente o momento em que Brook pode assumir, de forma cênica, a sua vertente relacionada ao seu aprimoramento espiritual. Dessa maneira foram estabelecidos espaços simbólicos que permitiram que o público vislumbrasse as múltiplas dimensões contidas no texto. De acordo com a afirmação de Banu (1982), o espetáculo atingiu seu propósito de relação com o sagrado, tanto pela proposição de montagem quanto pela sua temática. Uma vez que, nessa epopeia sufi, alegoricamente, todas essas relações dizem respeito ao ser humano, e às diversas possibilidades de aprimoramento no percurso do desenvolvimento espiritual.

\subsection{O RESULTADO DOS ELEMENTOSVISUAIS: O CENÁRIO E OS TRAJES DE CENA DE A CONFERÊNCIA DOS PÁSSAROS.}

$\mathrm{Na}$ temporada desenvolvida no Théâtre des Bouffes du Nord, o espaço selecionado por Brook, para desenvolvimento da representação do espetáculo compreendia as duas áreas do teatro, utilizando todo - espaço de representação disponível e ganhando assim mais profundidade de cena para a realização do espetáculo. Desse modo o ambiente proposto era completamente diferenciado da peça que o antecedia - L'Os, que concentrou a ação cênica somente no semicírculo frontal do palco (figura 32). 
Figura 32 - Estrutura de ocupação dos espaços da montagem de L'Os e de A Conferência dos Pássaros. Destaque para a linha com preenchimento que no espetáculo L'Os indicava a posição da paliçada - divisor entre o ambiente interno e externo da casa do protagonista.

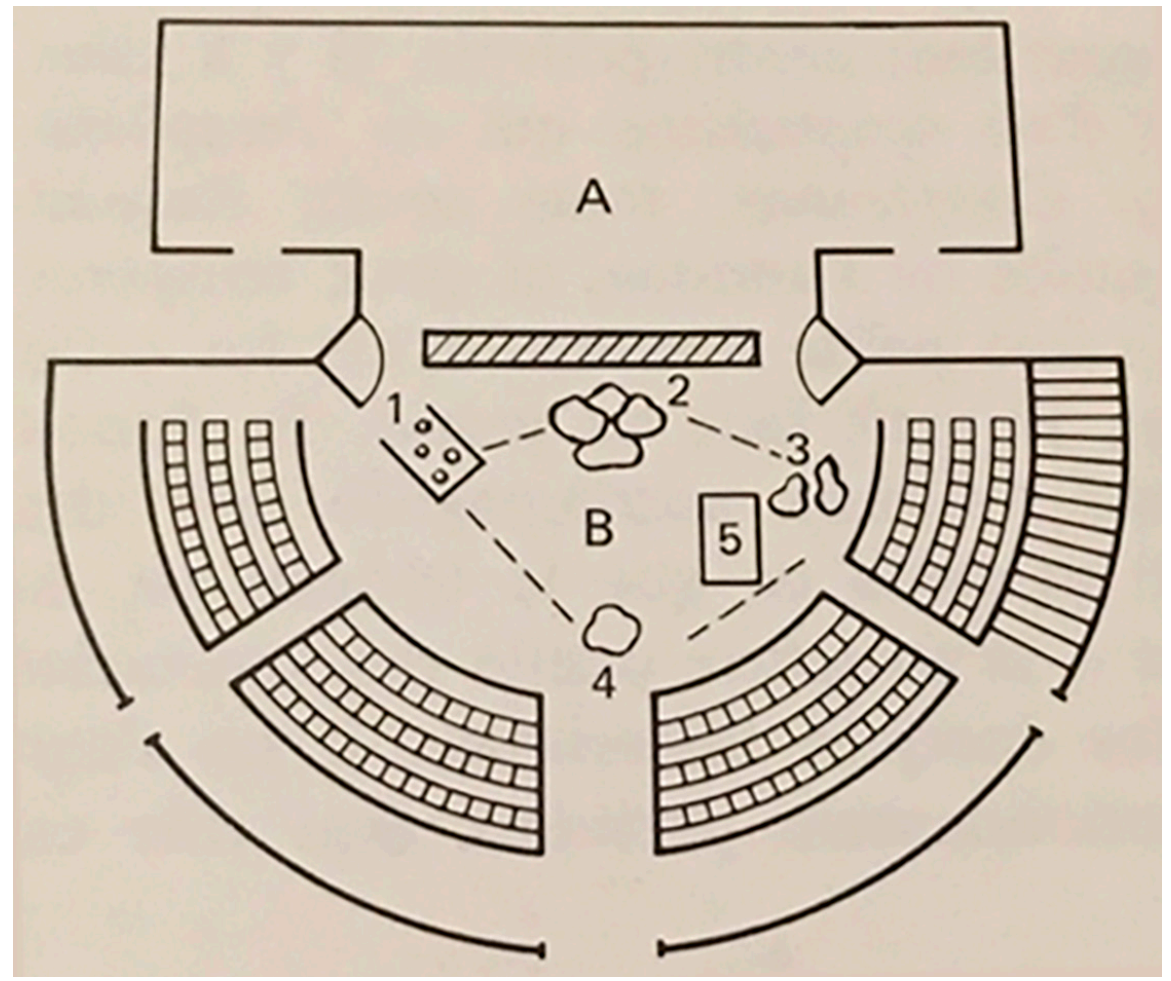

Fonte: Banu (1982, p. 258).

Ainda que tenha optado por ampliar o espaço de representação na montagem é possível perceber efetivamente a situação proposta por Brook do espaço vazio para o desenvolvimento do espetáculo. Ou seja, a cena é marcada pela completa ausência de cenários. Havia somente um resgate do processo vivenciado pelo grupo durante as expedições, que era a inclusão dos tapetes para definição da área de representação. Sendo assim havia dois grandes tapetes persas que cobriam todo o palco. Conferiam uma proposta de delimitação do espaço cênico e traziam um elemento para o plano do piso na encenação (figura 33). 
Figura 33 - Espaço cênico de A Conferência dos Pássaros com a delimitação dos dois ambientes determinado pelos tapetes persas.

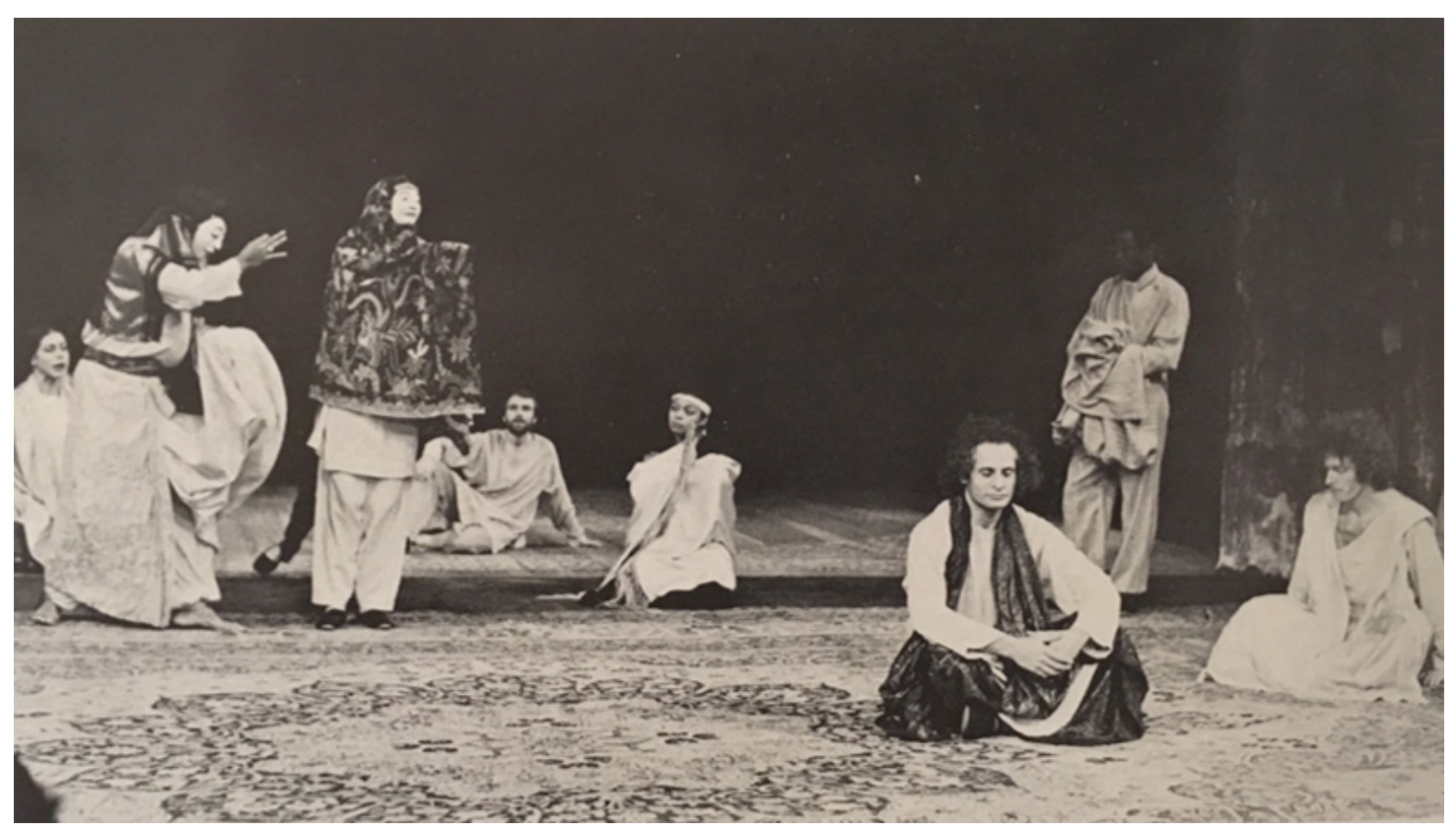

Fonte: Banu (1982, p. 258).

É evidente que o espaço destinado aos músicos, que tocavam ao vivo, também era delimitado por um tapete menor que cobria a cena, demarcando, assim, o espaço de cada um no espetáculo. Como se tratava de um texto alegórico, o símbolo do tapete, neste caso, também poderia, por meio da imaginação do espectador, remeter tanto para a fantasia, com referência ao tapete voador - amplamente difundido pelas histórias dos Contos das Mil e Uma Noites de Sherazade -, como no elemento simbólico do tapete de oração utilizado pelos

\section{8}

mulçumanos - condizente com a temática sufi.

Esta solução proposta por Sally Jacobs estabelecia uma sutil atmosfera oriental que, de fato, era a pretensão da montagem, elemento de composição da ambientação do espetáculo de modo bastante perspicaz. Portanto, de acordo com a construção do texto proposto por Brook e Carrière que pretendia atingir qualquer ser humano na busca pelo divino, a composição com os tapetes não pretendia que se realizar qualquer construção temporal 
ou cultural para transmissão da mensagem. Não havia, assim, qualquer intenção de materializar a época ou a cultura persa do século XII, referente ao contexto histórico da composição do texto de Attar.

Segundo Myers a opção de seleção do tapete, tratavase de solução adequada à proposta, pois, para ele, o tapete "é belo, é calmo, é digno. Ele permite uma concentração interior que conduz a um estado menos nervoso. Se chega a uma calma trabalhada" (apud BANU, 1985, p. 260). É relevante destacar que, para a apresentação do espetáculo no Festival de Avignon, o espaço também era composto por poucos elementos de cena, porém não foram utilizados os tapetes persas. $\bigcirc$ piso permaneceu com terra e areia no chão, conforme demonstra a figura 34. Essa escolha, por deixar o piso com seu acabamento natural em areia, certamente trouxe outro significado para a montagem, uma vez que a areia conduz naturalmente o imaginário dos espectadores para o deserto proposto no texto.

Figura 34 - Espaço cênico de A Conferência dos Pássaros no Festival de Avignon piso com areia e terra

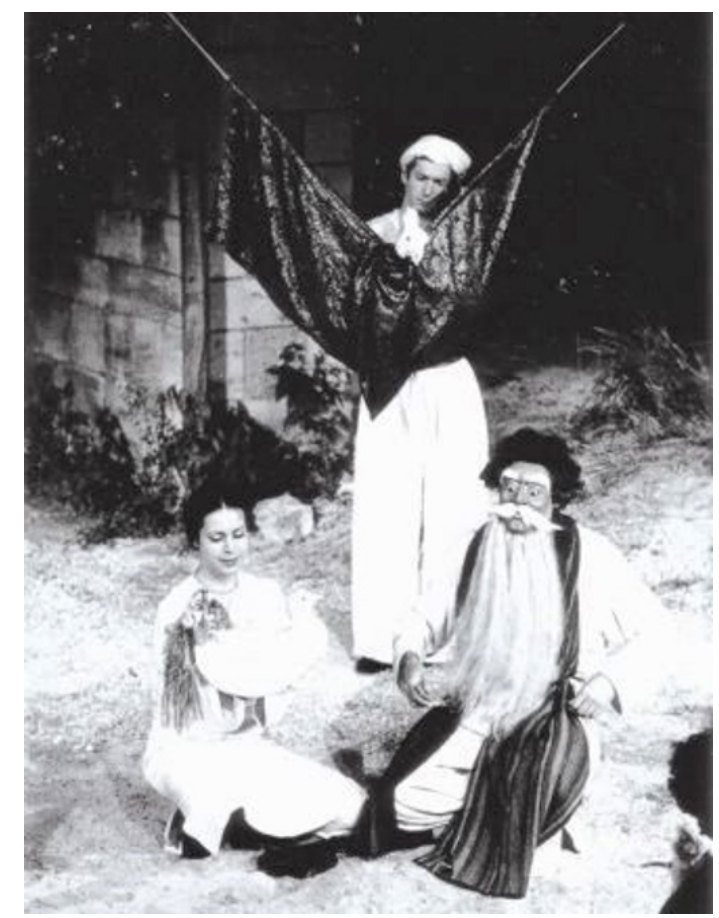

Fonte: Bernard; Ferreira (2010). 
Em relação à cenografia, é possível identificar que o espaço composto pelos tapetes em cena, remetem a uma linguagem simbólica, de modo que o espectador é levado a estabelecer em sua própria imaginação os espaços narrados pelo texto. Desse modo percebese que a simbologia estava fortemente ancorada pela narrativa do espaço de representação. Nesta peça, os elementos de destaque na composição espacial da cena se tornam os pássaros fantoches, as máscaras balinesas, o uso de véus, tecidos e bastões de bambu, entre outros objetos que compõe o espetáculo, sendo relevante compreendê-los pois estes elementos permitiram que Brook experimentasse o seu primeiro contato com o Teatro Sagrado.

Cabe reafirmar que o pássaro do texto de Attar, na verdade, é uma alegoria para se falar do próprio ser humano, e o espetáculo produzido por Brook deveria refletir esta ideia. Deste modo, vestir o ator com uma máscara figurativa em sua cabeça, além de dificultar bastante o desenvolvimento das cenas, seria uma solução estéril; imitar as aves poderia privar a compreensão da mensagem da fábula; na mesma medida, se os atores não tivessem o menor vestígio da Poupa, do Falcão, da Garça ou da Coruja, poderiam se incorrer no risco de a mensagem ficar em um discurso somente essencialista - um discurso em que a moral superaria a relevância da viagem exposta na apresentação.
A peça sugere que a ambiguidade estivesse presente na apresentação em que tanto o ser humano como - pássaro fossem reconhecidos em cena. Decidiuse portanto, que o núcleo de atores transitaria entre a dupla polaridade destacada nas intenções do texto original e que também acompanharia o movimento de progressão da narrativa. Assim, a intenção sugerida por Attar torna-se chave para a encenação de Brook.

De acordo com a observação da natureza, a primeira resposta dos pássaros é sempre através dos sons. Por isso a Poupa é convocada pelo som que se inicia distante e vai se aproximando aos poucos, o que serve também como uma maneira alternativa de indicar a profundidade espacial. A partir desta provocação, outros sons estranhos ecoam uns sobre os outros, passando a sensação de montes e vales. O conjunto de aves se move em direção ao chamado da Poupa. E, então, o espetáculo se inicia com a migração acústica das personagens, quando, nesse momento, o pássaro predomina sobre a figura humana.

No palco os atores estão vestidos em trajes largos: túnicas curtas e calças em tons predominantemente ocre. Os materiais empregados nas roupas remetiam à elegância e limpeza das civilizações rurais, com produtos feitos à mão, estranhos a qualquer tratamento químico. Os materiais dos trajes deveriam transmitir a conotação das civilizações primitivas. Os trajes de cena possuíam 
homogeneidade, uma unidade, que enfatizava a relação voltada para o coletivo. A variedade das aves era perceptível por meio de pequenas peculiaridades que eram aplicadas à unidade inicial. A diferença era realizada a partir de um elemento móvel - como por exemplo, um cachecol, um xale, ou mesmo um leque (figura 35 ). Os tecidos e materiais, bem como as cores, variavam para cada ave. No entanto, ainda deveria predominar a imagem humana mesmo com estas intervenções.
Para identificação e desenho do pássaro que era representado, foi solicitado que cada ator usasse um gesto especial para sua reconhecimento: os dedos tortos; os braços cruzados; ou, as palmas das mãos sempre abertas e levantadas. Todas as posições, em si, de algum modo sugeriam uma espécie de pássaro, mas não deveriam imitar seu comportamento de modo idêntico. A sua finalidade era induzir à imaginação dos espectadores e, ao mesmo tempo, perturbar a

Figura 35 - Figurino de A Conferência dos Pássaros, ator ao centro é o Pavão e utiliza um leque como instrumento de reconhecimento do pássaro que representa.

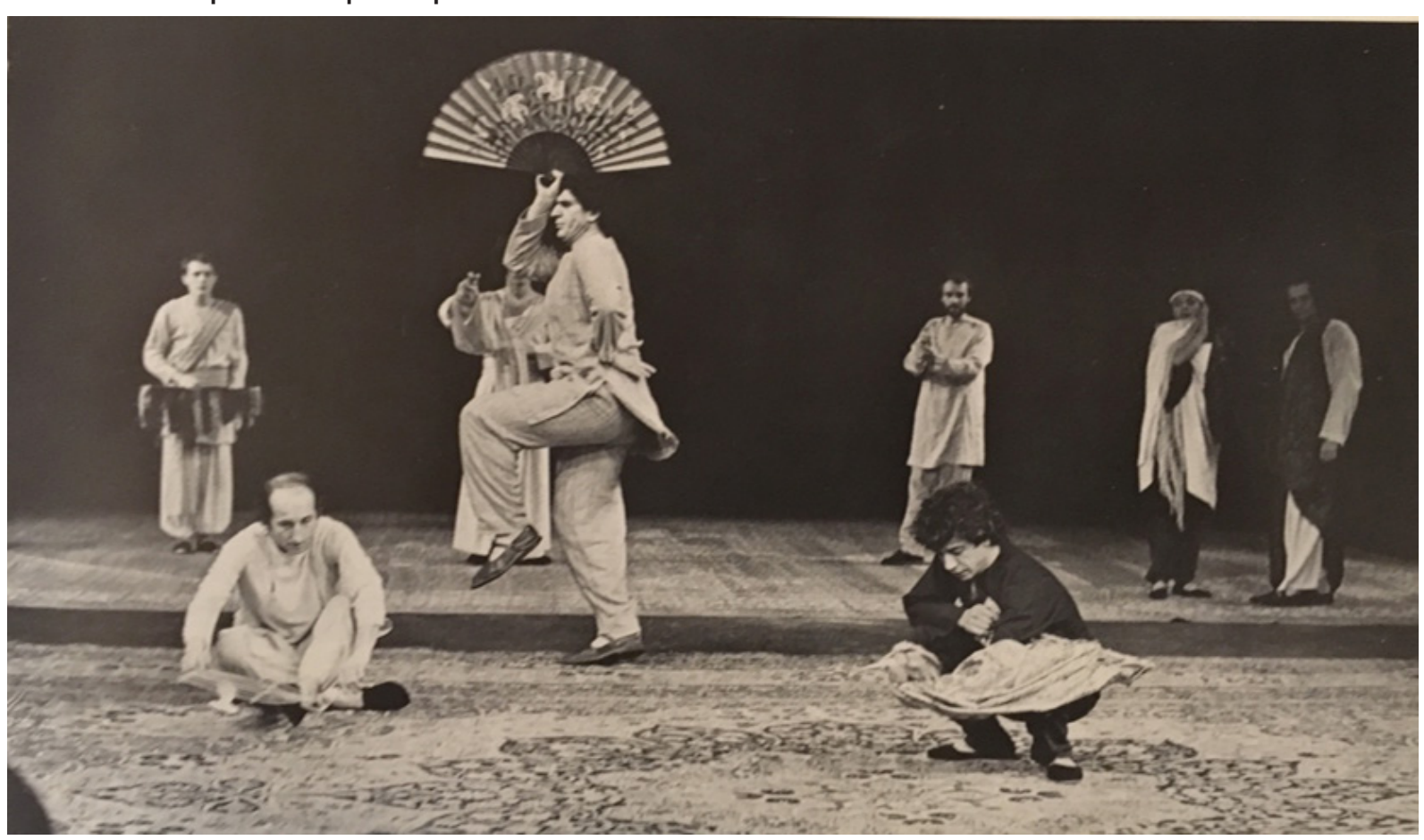

Fonte: Banu (1982, p. 263). 
familiaridade com o corpo humano. À caracterização visual da personagem ainda era acrescido o trabalho vocal, alternando os arrulhos e os sons de cada uma com a utilização estereotipada de voz para indicar o caráter da ave.

Assim os atores poderiam desfrutar de maior liberdade para favorecer sua caracterização. De acordo com Brook (apud BANU, 1982, p. 264), eles poderiam escolher "entre um instrumento, como por exemplo a transformação de um dedo, e um som. Além disso, poderiam escolher entre um pincel, uma escova, ou outro objeto". Mas não deveriam perder de foco que para representação inicial das aves, a base era sempre o corpo pois o ser humano e o pássaro deveriam ser uma mesma figura.

Na primeira parte do espetáculo, os pássaros duvidam, adiam e até fogem da ideia da Poupa. Até mesmo se recusam a prosseguir sua viagem em nome de um contentamento que os torna surdos a qualquer chamado de fora. Para alguns dos pássaros a figurinista reforçou sua atitude, sugerindo um modo particular de representação:

- Perdiz evoca amorosamente colares de pérolas em torno dos dedos;

- Periquito, com uma voz pequena, se mostra atrás das grades de uma gaiola, concordando com seu estado em cativeiro;

- Pavão, para apoiar uma voz presunçosa, se exibe através de uma gama multicolor, composta por sua cauda e seu bico (deve notar-se que a peça ressalta uma atitude, como se a exibição da cauda demonstrasse exibição do orgulho);

- Coruja aparece pendurada num ramo, que ela não vai abandonar;

- Pardal aparece adornado com um avental azul - e pede desculpas em um tom choroso, mostrando o desejo de ter ou ser aquilo que não somos (BANU, 1982).

Outro elemento fundamental nos trajes propostos para - espetáculo foi a utilização de máscaras balinesas em cena. Para Brook (1994, p. 287), em seu texto Ponto de Mudança, "é evidente que há máscaras e máscaras. Existe algo muito nobre, muito misterioso, muito extraordinário, que é a máscara". No entanto, para o diretor, a maneira como a máscara era manuseada era fundamental para que se estabelecesse a relação com este objeto.

A máscara tradicional, assim como as máscaras balinesas, segundo o diretor são vivificantes e afetam tanto o usuário como o observador de uma maneira positiva. Ela não é uma "máscara” em sua essência, já que se trata de uma imagem da natureza essencial. Em outras palavras, uma máscara tradicional equivale ao 
retrato de um ser humano sem máscara.

Em A Conferência dos Pássaros a escolha deste tipo de máscara, realísticas, estava posto de acordo com as palavras de Brook (1994, p. 289), "no sentido em que, contrariamente àquilo que acontece com as máscaras africanas, suas feições não eram distorcidas; muito pelo contrário, o efeito pretendido eram completamente naturalísticas".

\begin{abstract}
A máscara tradicional se constitui num retrato genuíno, um retrato da alma, uma fotografia daquilo que raramente se vê, e apenas seres humanos verdadeiramente desenvolvidos: um invólucro que é reflexo completo e sensível da vida interior. [...] Essas máscaras, apesar de imóveis, parecem estar cheias de vida. Desde que o ator respeite certas etapas, no momento em que usa a máscara, esta se torna viva num sem-número de maneiras. Uma máscara desse tipo possui a extraordinária característica de apesar de uma quantidade absolutamente inesgotável de expressões quando é posta sobre uma cabeça humana, desde que o ser humano que está dentro dela seja sensível à sua significação (BROOK, 1994, p. 289).
\end{abstract}

Brook (1994) diz que relutou na utilização das máscaras neste espetáculo, porém, desde a primeira vez que a introduziram no processo de pesquisa, trabalharam de forma que a individualidade do ator pudesse transparecer através de seu rosto e, por meio de uma técnica ou outra, esse trabalho resultou no livrar-se das máscaras superficiais dos atores em cena. "Seus rostos se convertiam assim em um espelho de melhor qualidade - no mesmo sentido que um sufi afirmaria que seu espelho estaria se tornando mais polido" (BROOK, 1994, p. 297). Um espelho que reflete de forma mais limpa aquilo que está acontecendo no interior de seu rosto. 


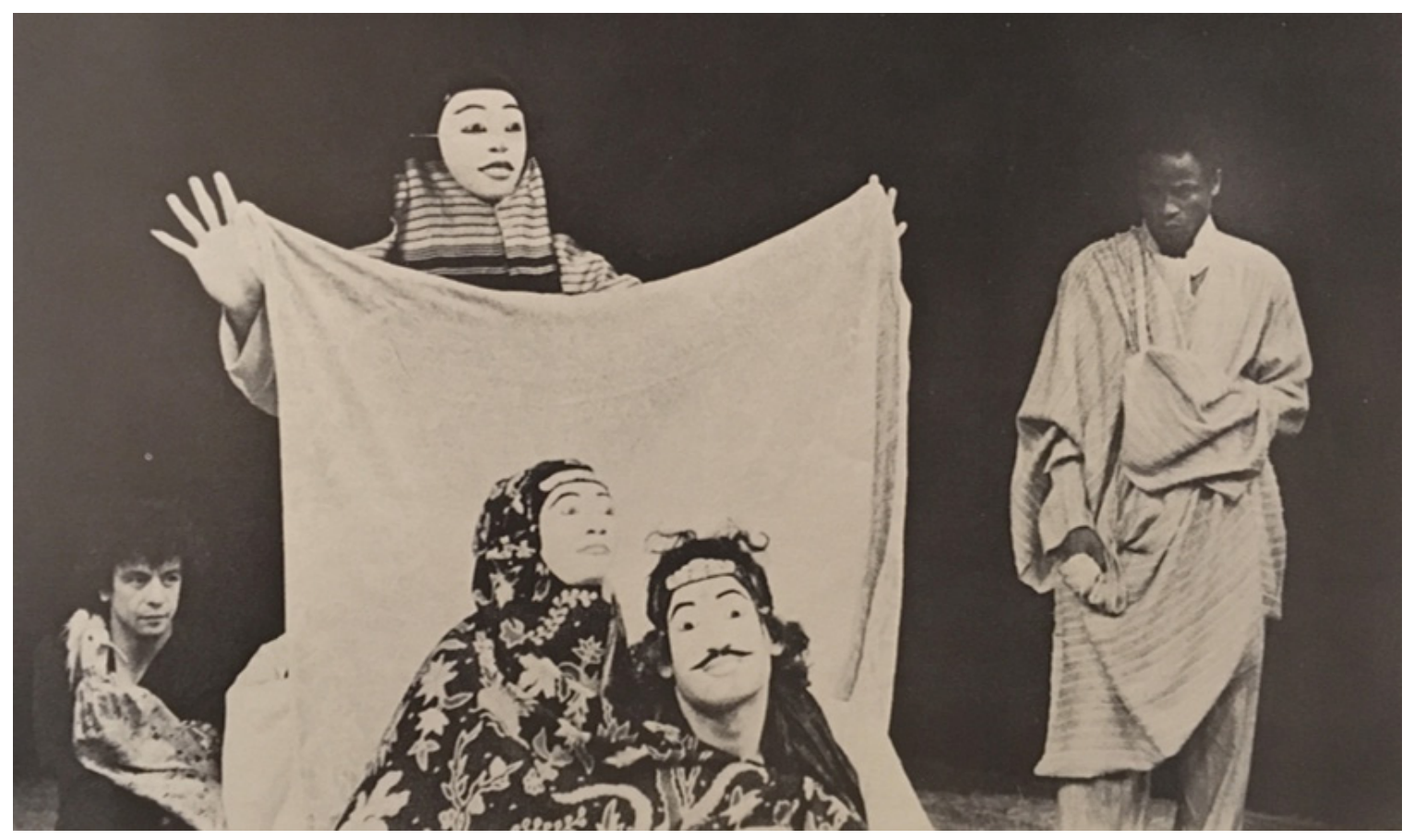

Fonte: Banu (1982, p. 275)

Tendo em vista a trajetória de Brook, é evidente que o processo de simplificação tanto da cena, como de seus elementos visuais - trajes de cena e cenários -, não ocorreu somente com a realização do espetáculo A Conferência dos Pássaros em 1979. Contudo, deve-se ressaltar que a criação dessa peça e consequentemente a busca por uma nova linguagem para a representação teatral, teve início alguns anos antes com as primeiras investidas do Centro de Pesquisa Teatral pelas cidades africanas em 1972. Foi naquele momento que ganhou força a investigação de Brook e seu grupo, pela exploração de uma nova forma de estabelecimento do jogo teatral, aproximando o ato cênico do espectador, com a exploração da imaginação da plateia.

Deste modo, o cenário e os trajes de cena propostos por Jacobs para esta encenação se encaixaram nesse processo cênico. A cenógrafa já trabalhava com Brook e esta foi uma de suas últimas realizações em parceria com o diretor. Devido a imersão de Jacobs no 
processo investigativo do grupo, sua concepção estava inteiramente integrada na busca por essa nova forma de concepção cênica, que estava calcada mais na sugestão dos elementos visuais do que na reprodução realista dos elementos presentes no texto.

Com elementos e tecidos bastante simples, explorando adereços e máscaras de modo a encaixarse com o trabalho do ator, a designer contribuiu contundentemente para a investigação de Brook. E fez com que este espetáculo se tornasse, de fato, o início da simplificação dos elementos visuais na obra de Brook, devido a sua aposta na complementação da imaginação do público.

Ainda é relevante salientar que, de certa maneira, o espaço sagrado, em que Brook estabelece esse primeiro contato, é também reflexo do aprimoramento e amadurecimento espiritual do diretor. Pois naquele mesmo ano decidiu, a convite de sua mentora, realizar - filme Encontro com Homens Notáveis que narrava a trajetória de Gurdjieff. Trata-se de um primeiro momento em que Brook se sentiu seguro para poder expressar, no palco, seu pensamento filosófico em relação ao aprimoramento da espiritualidade. 



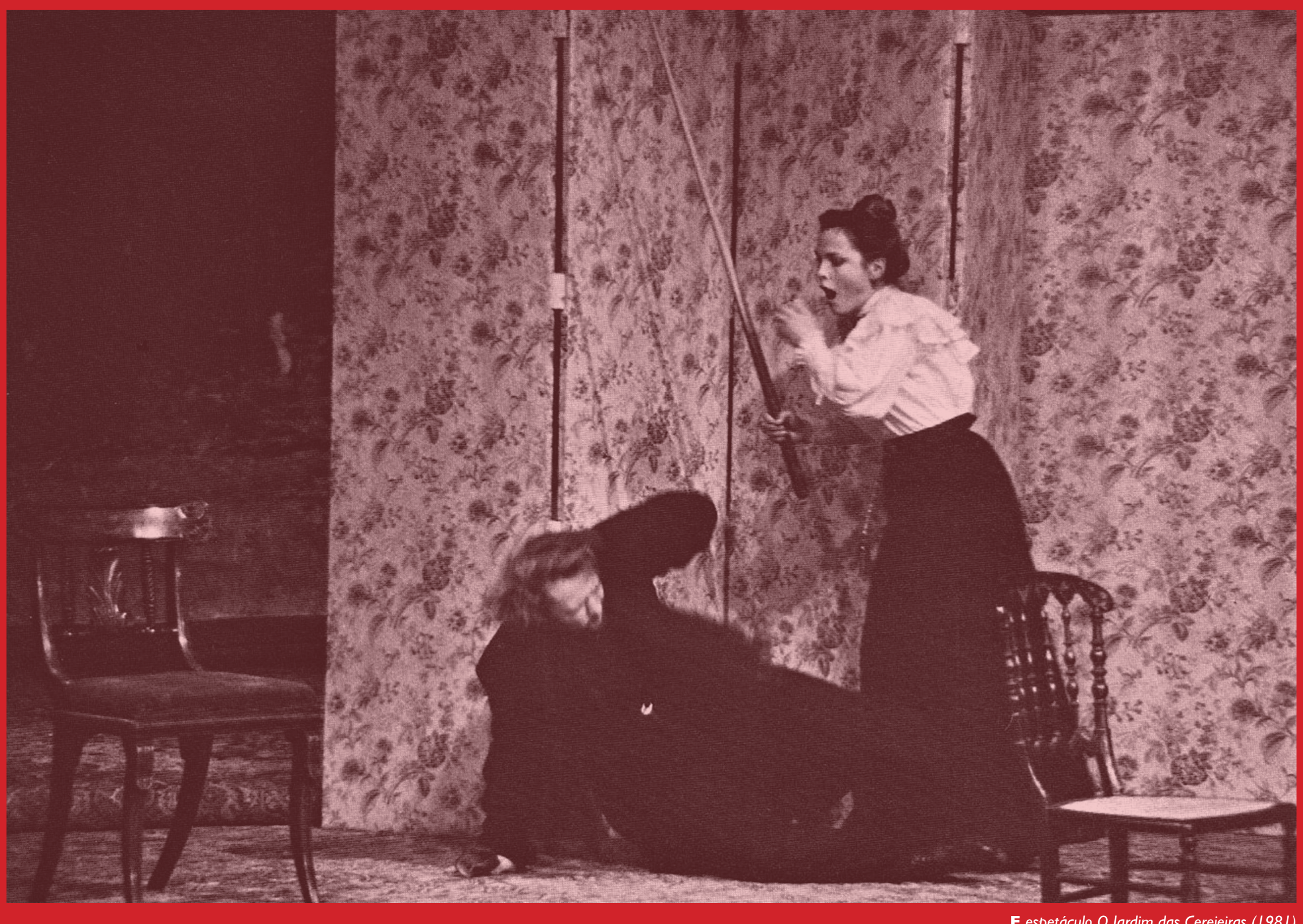

E espetáculo O Jardim das Cerejeiras (I98I) 



\section{O ESPAÇO CÊNICO TORNA- SE PROTAGONISTA NO TEATRO SAGRADO:OJARDIM DAS CEREJEIRAS (198I) E A TEMPESTADE (1990)}

Este capítulo apresenta um aprofundamento de Brook em relação à sua pesquisa referente ao Teatro Sagrado, em que o espaço cênico adquire um maior protagonismo em relação às suas montagens. Trata-se, também, de um período em que ele resgata as montagens de grandes dramaturgos da história do teatro mundial como Tchekhov e Shakespeare.

Desse modo são analisados, propriamente, os cenários e trajes de cena dos espetáculos 0 Jardim das Cerejeiras (I98I) e A Tempestade (1990). De forma análoga ao capítulo anterior, para que haja uma melhor compreensão dos elementos visuais, entende-se que é fundamental realizar uma breve análise dos dois textos para melhor percepção das questões pertinentes à configuração espacial do espetáculo, bem como identificar como se deu o processo de montagem das duas peças.

4.I - AS ORIGENS DA MONTAGEM DE O JARDIM DAS CEREJEIRAS E REFLEXÕES DE BROOK SOBRE TCHEKHOV

Vale ressaltar, que embora Brook tenha nascido em Londres, seus antepassados são russos. Como coloca 
Bonfito (2009), Brook é filho de imigrantes russos e em sua carreira é possível identificar várias interferências extraídas da cultura russa, o que, de algum modo, o torna um pouco mais próximo das questões abordadas por Anton Tchekhov em seu texto. Em entrevista a Godard (1981), o diretor inglês relatou que já havia lido as quatro ou cinco versões do texto de Tchekhov - $O$ Jardim das Cerejeiras - que existiam em francês na época e também as várias em inglês, além do texto original em russo quando decidiu montar o espetáculo.

A leitura no original foi possível pois aprendeu russo em Oxford no tempo de estudante, como pode aprimorar seu conhecimento quando trabalhou com a mãe de sua esposa, Natasha Parry, que tinha origem russa. Contudo aprofundou-se na língua durante o processo de adaptação do espetáculo com Carrière para o francês, de modo a tornar o texto menos marcado por quaisquer traços temporais das traduções existentes. Em suas experiências anteriores de adaptação de textos, os espetáculos geralmente eram uma recriação mais poética a partir de uma visão de Carrière.

De acordo com Brook (1994), era imprescindível essa interferência, pois a sensibilidade da sociedade era distinta do momento em que os autores haviam escrito. Todavia, com o texto de Tchekhov, houve uma mudança. $O$ grupo passou a perseguir a fidelidade ao texto, uma vez que, na visão do diretor, uma das qualidades essenciais do autor russo era a precisão da escrita. Ele compara a poesia tchekhoviana com a beleza de um filme: a sucessão de imagens naturais e justas. Além disso, para ele, Tchekhov procurava o natural e queria que tanto a atuação quanto a encenação fossem tão fluentes e simples como a vida (BROOK, 1994).

Revelou que, durante a adequação do texto, existiu uma tentação de rebuscar as sentenças, mas logo perceberam que em russo elas são bastante simples. Assim, na opinião de Brook (1994), tanto Shakespeare quanto Tchekhov são os dois grandes autores teatrais. Sabe-se que Shakespeare é uma importante referência para o encenador, uma vez que já havia realizado diversos de seus espetáculos. E, naquele momento, realizar um espetáculo de Tchekhov se tornava um bom desafio.

Até a montagem de $O$ Jardim das Cerejeiras, Brook ainda não havia se debruçado sobre as peças do escritor russo. Alguns anos antes, expôs que queria realizar a montagem de As Três Irmãs, mas que, ao final, decidiu fazer $O$ Jardim das Cerejeiras, uma decisão que parecia bastante natural, pois o Théâtre des Bouffes du Nord tinha muitas semelhanças com A Casa de Ranievskaia ${ }^{13}$,

${ }^{13} \mathrm{~A}$ ação de $\mathrm{O}$ Jardim das Cerejeiras de Tchekhov se passa na propriedade de Liubov Andreievna Ranievskaia, que foi morar em Paris após a morte de seu filho, por afogamento, na propriedade onde fica o lindo jardim das cerejeiras. A Casa de Ranievskaia havia ficado abandonada e, devido às dívidas da família estava indo a leilão para saldar seus dividendos. A semelhança entre a casa do texto e o Théâtre des Bouffes du Nord, é justamente o aspecto de degradado que ambos têm, a casa pelos relatos do texto e o teatro por sua aparência. 
que era a alma do espetáculo.

$\mathrm{Na}$ escrita bastante concentrada de Tchekhov ressaltava-se $\circ$ uso mínimo de palavras, $\circ$ que para Brook permitia a sua comparação com Pinter ou Beckett. Tal qual os autores citados, é a construção da escrita que conta, assim como o ritmo e a poesia puramente teatral da palavra certa no momento e no tom adequados. "Alguém diz somente sim, mas de tal forma que o sim se torna uma expressão perfeita, não podendo ser substituída por outra" (GODARD, I98।, n.p., tradução nossa).

Como foi decidido pela fidelidade ao original, pretendiam que $\circ$ texto em francês se ajustasse perfeitamente ao russo e permanecesse forte e realista. Correram o risco de cair em aproximações artificiais, pois as equivalências eram possíveis para a escrita literária mas, para a linguagem falada, algumas vezes, ficava bastante estranho. Carrière e Brook tiveram o cuidado de passar fala por fala com os atores, considerando a estrutura que estava baseada na evolução do pensamento tchekhoviano.

Respeitaram a pontuação em russo, pois os pontos, as vírgulas e os pontos em suspensão são fundamentais para a compreensão das intenções do texto. Emitiram uma série de mensagens codificadas. Revelaram, por meio da sua utilização, os relacionamentos e os sentimentos das personagens. De acordo com o Brook
(1994), era a partir da pontuação que se tornava possível compreender o que as palavras escondiam.

Comparava Tchekhov a um exímio editor de cinema, mas que, ao invés de cortar para passar de uma imagem para outra, ele realizava a passagem de um sentimento para outro antes de tudo ser expresso em cena. No momento em que o espectador começava a ter empatia demais por uma personagem, apresentavase uma situação inesperada que desestabilizava essa proximidade. Em suas peças, tanto os indivíduos quanto a sociedade, estavam em contínuo estado de mudança. E, para Brook (1994), Tchekhov era o dramaturgo do movimento da vida, sorridente e sério, engraçado e amargo.

O autor russo definia suas peças como comédias tema que, por diversas vezes, foi conflito com o diretor Stanislávski devido ao tom dramático e a lentidão que este último imprimia em suas montagens dos textos. Porém, segundo Brook ( 1994), o fato de ser considerada como comédia não deve induzir à conclusão de se montar 0 Jardim das Cerejeiras em estilo vaudeville.

Por ser médico, Tchekhov era um meticuloso observador do comportamento humano. Conhecia o significado das suas atitudes, sabia discernir o essencial e expunha os elementos diagnosticados. No que julgava ser a comédia da vida humana revelava suas observações com ternura e atitudes simpáticas, evidenciando quaisquer questões 
sem sentimentalismos. Por outro lado também demonstrava as imperfeições e os sinais de mal-estar de suas personagens sem medo. Outro tema reincidente em seus textos era a presença permanente da morte, porém sem um caráter negativo. Essa consciência, para o encenador inglês, era equilibrada com o desejo de viver. Suas personagens tinham a sensação do momento e a necessidade de prová-lo completamente.

Brook (apud GODARD, 198I, n.p., tradução nossa) prossegue afirmando que

Como nas grandes tragédias, encontrase em si um equilíbrio perfeito entre a vida e a morte. Ele morreu jovem, tendo viajado muito, escrevendo e amado depois de participar de projetos de melhoria social. Ele morreu logo depois de pedir champanhe, seu caixão foi transportado em um vagão marcado "ostras frescas" (...) Essa consciência da morte e momentos preciosos para viver traz-lhe o senso de parente, isto é, dizer uma distância suficiente para nunca perder de vista o lado cômico dos dramas.

Indicava que, para não trair as intenções do autor, era preciso coincidir os elementos cômicos e dramáticos da peça. Reiterava que, se alguém quisesse ser fiel a Tchekhov, o responsável pela invenção do teatro moderno, era preciso inovar. Para Brook (1994), em O Jardim das Cerejeiras, cada personagem seguia a sua própria existência, e nenhuma era semelhante à outra.
O que, do ponto de vista histórico e político da época, revelava um microcosmo de tendências: aqueles que anunciavam as transformações sociais e os que estavam no caminho do desaparecimento.

Vistas de fora, suas vidas pareciam vazias e irrisórias, mas ficava evidente que os desejos permaneciam vivos, latentes. As personagens não estavam desiludidas, pelo contrário buscavam, à sua maneira, o melhor de si mesmas, no campo social e emocional. Não se envergonhavam de viver plenamente as diversas nuances e reviravoltas de sentimentos. $O$ maior drama era que a sociedade, o mundo exterior, os impedia, os prejudicava, mas, apesar destes conflitos, elas não eram destrutivas. A complexidade de seu comportamento não era indicada nas palavras, revelava-se na construção de um mosaico repleto de detalhes.

Deste modo Brook (apud GODARD, 198I, n.p., tradução nossa) ressaltava que a única coisa a ser feita era trabalhar todos os detalhes e, pela insistência, o espetáculo começaria a ganhar forma. Como se tratava de um processo laborioso, eles repetiam as cenas diversas vezes até que a palavra estivesse colocada da forma correta. Durante o processo ele entendia que seria impossível que alguém chegasse à encenação definitiva, pois ela se desenvolveria de forma autônoma e, a cada momento, novas camadas de sentimentos e nuances seriam acrescidas à cena. 


\section{I.I - Questões evidentes em 0 Jardim das Cerejeiras}

O Jardim das Cerejeiras foi a última peça escrita por Tchekhov. Foi encenada pela primeira vez sob direção de Stanislávski e estreou no Teatro de Arte de Moscou em 1904, mesmo ano da morte do autor, que, por também ser médico de formação, tinha consciência do seu estado de saúde e sabia que a morte estava próxima. Assim, nesse espetáculo, a morte é onipresente, porém, não traz uma carga negativa ou desagradável. A sua consciência é compensada pelo desejo de viver.

Esse texto traz à tona a temática da brevidade da vida e da necessidade de aproveitar e celebrar cada momento. Tchekhov morreu jovem - aos 44 anos. Segundo Brook (1994) depois de ter viajado, escrito e amado enormemente; após ter participado dos eventos de seu tempo e vivenciado os grandes projetos de reforma social. Sua consciência da morte e os momentos preciosos que puderam ser vividos deram, ao seu trabalho, um significado de relatividade, ou seja, uma distância suficiente para nunca perder de vista o lado cômico dos dramas.

Devido à maestria do russo, nenhuma personagem é semelhante a outra, especialmente em 0 Jardim das Cerejeiras, em que cada uma tem sua própria existência e apresenta as diferentes tendências políticas da época. Há as que acreditam nas transformações sociais, bem como as que estão mais ligadas a um passado que já não existe. Nenhuma delas pode alcançar satisfação ou plenitude e, analisadas friamente, suas existências não estão longe de parecerem vazias ou sem sentido. Algumas vezes se mostram consumidas por desejos intensos. Ao contrário de estarem desiludidas, cada uma a seu modo, busca uma melhor qualidade de vida social e emocional. A grande problemática é que a sociedade bloqueia as suas energias.

O diretor inglês enfatiza que a complexidade do comportamento das personagens não é indicada no texto somente pelas palavras; surge da construção bastante elaborada do autor e se concretiza pelos inúmeros detalhes. Novamente é preciso ressaltar e compreender que as suas peças não são sobre personagens letárgicas. Elas são cheias de vida e desejos, porém se encontram em um mundo apático e são conduzidas a dramatizar quaisquer eventos, por menores que sejam, devido ao seu apaixonado anseio de viver. Longe de serem desistentes, estão sempre à flor da pele e apresentam evidente dificuldade de comunicação entre si.

A peça ocorre na Rússia, no início do século $X X$, em um momento que antecede a revolução social. Foi um período em que as questões socioeconômicas estavam em pleno embate. Observou-se a ascensão da classe média após a abolição da servidão na metade do século XIX e o consequente declínio da aristocracia. Tchekhov 
apresenta a aristocrata Liubov Andreievna Ranievskaia exatamente nestas circunstâncias que, sem condições de permanecer morando em Paris onde vivia há cinco anos, foi obrigada a retornar para o seu jardim de cerejeiras, uma grande propriedade com uma enorme casa velha.

Devido às progressivas mudanças políticas e econômicas ocorridas, a propriedade não era mais produtiva, e, portanto, não trazia mais rendimentos. Foi hipotecada e estava prestes a ser leiloada. No decorrer das ações da peça fica evidente o desconforto de Luibov e seu irmão Leonid Andreiêvitch Gaiev em lidar com as situações construídas no passado, assim como a inaptidão de viverem no presente e lidarem com as suas dificuldades. Fatos estes que evidenciam a importância do tempo, sobretudo neste espetáculo de Tchekhov.

Torna-se oportuno uma breve apresentação das personagens, assim como um apontamento das ações propostas pelo autor. Gaiev é, também, proprietário do jardim das cerejeiras e se apresenta como "um pobre e velho bebê de cinquenta e um anos" (ELIAS, 20I5, p. II0) que é entusiasta de jogo de bilhar. Tem apreço por sua irmã e a ama profundamente, porém em alguns momentos revela que a considera uma criatura de moral duvidosa.

Ánia, a filha mais nova de Liubov, tem dezessete anos e foi a Paris buscar a mãe; permanece cheia de sonhos e alegre do início ao fim do espetáculo. Vive na esperança de uma vida melhor ao lado do admirado Piotr Serguêievitch Trofimov - ou Pétia, o "eterno estudante". De acordo com Elias (20I5), na versão de Peter Brook há uma acentuação da relação entre os enamorados "a ponto que acreditamos num final feliz para os dois" (ELIAS, 2015, p. III). Por sua vez, Trofimov, com 26 ou 27 anos, prega sobre o trabalho como forma de solucionar o problema de estagnação da sociedade russa e acredita no avanço permanente da humanidade.

O trabalho de organização da casa da família é mantido pela filha adotiva de Ranievskaia, Vária, que tem 24 anos. Ela se apresenta como uma mulher "limitada, de roupa preta, que parece uma freira, chorona" (ELIAS, 20I5, p. III). Os demais a chamam de "Madame Lopakhin", fato que, no decorrer do enredo, salienta que ela realmente almeja um pedido de casamento do rico comerciante Lopakhin. Mesmo assim ela abandona tudo e vai morar em um convento bastante distante, o que de fato ocorre no final do texto.

Em um outro grupo social, destaca-se o filho de antigos camponeses que está ascendendo socialmente lermolai Aleksêievitch Lopakhin. Durante o início da ação cênica, esforça-se em alertar os donos da propriedade da inevitabilidade da venda e tenta propor-lhes algumas alternativas. Anuncia que o jardim das cerejeiras está à 
venda e, ao fim, torna-se o novo proprietário das terras onde seu pai e avô eram servos. De acordo com Elias (20I5, p. II0),

A relação de Lopakhin com Ranievskaia é ambivalente. Ele nutre por ela sentimentos mistos de admiração, de ternura, de atração, de reverência, de submissão. $O$ laço que os une no presente é o da amizade, mas no passado o que unia seus pais era a relação de servidão e propriedade.

Boris Borísovitch Simeonov-Pichtchik também é proprietário de terras e, assim como Ranievskaia, está endividado. É um velho glutão, maltratado pela gota, que vive em busca de empréstimos para resolver seus problemas financeiros e está à espera de que algo aconteça para mudar a sua vida. O falecido pai de Boris dizia que os "Simeonov-Pichtchik descendem em linhagem direta do cavalo que o imperador Calígula nomeou senador ... [e que a sua] [...] única desgraça é nunca ter dinheiro [...] [porque] [...] o cão esfomeado só acredita na carne" (TCHEKHOV, 2003, p.98). Como explicita Elias (2015), trata-se de um homem que reconhece a necessidade da inverdade como condição da sobrevivência.

Relacionado aos agregados de Liubov, destaca-se Charlotta Ivanovna. Não se sabe ao certo sua idade, porém tem-se ciência que é órfã e foi educada por uma senhora alemã quando seus pais morreram. Tornou- se preceptora e, por ser prestidigitadora, realiza no decorrer da ação alguns truques de mágica. É evidente que em alguns momentos do texto de Tchekhov ela desempenha um papel de comentarista e condutora da ação dramática.

$\mathrm{Na}$ sequência, dentre os demais criados, observa-se ○ velho Firs de 87 anos, que já era jovem quando o pai de Liubov nem era nascido. De certa maneira está ainda apegado à antiga estrutura social, quando se sabia quem eram os camponeses e quem eram os senhores de terras - tempo em que o jardim das cerejeiras era bastante produtivo e com as cerejas colhidas faziamse conservas e licores. $\mathrm{Na}$ montagem de Brook, Firs tem um ritmo ágil e rápido, tanto nas falas como em seus movimentos, seguindo indicação de Tchekhov nas rubricas do início da peça que explicitam essa característica da personagem.

Já a criada Duniacha vive enfeitada. É ingênua, suspirante e desperta paixões ao longo da peça. Por ter convivido com os senhorios desde pequena se desacostumou com a vida simples. Para Firs, ela é bastante lenta no trabalho. Está apaixonada por lacha que entende ser um homem fascinante, viajado e culto que "sabe falar tão bem de tudo" (TCHEKHOV, 2003, p.88). lacha, por sua vez, é um jovem criado alegre, sedutor e aproveitador, que chega de Paris com Liubov, para onde deseja muito voltar. Debocha descaradamente de Gaiev e tem um 
rápido caso amoroso com Duniacha, a quem chama de "meu bombonzinho" (TCHEKHOV, 2003, p.88).

$\mathrm{Na}$ montagem de $\mathrm{O}$ Jardim das Cerejeiras, lacha é interpretado por Maurice Benichou, que faz a personagem safada e esperta, com tons arlequinescos. Finalmente, Semion Panteleievitch Epikhodov, contador, atrapalhado e angustiado, uma figura dissonante e perturbadora, que é recebido sem ser convidado. Está muito apaixonado pela criada Duniacha, mas para lacha trata-se de um sujeito bobo. É a personagem que, na montagem de Brook, tende levemente ao ridículo e confere ao espetáculo nuances ligeiramente cômicas.

A peça é dividida em quatro atos e a ação do espetáculo transcorre na propriedade de Ranievskaia e Gaiev, dura aproximadamente seis meses. Inicia-se em maio, na primavera, justamente na época em que as cerejeiras estão florescendo. Cada ato acontece em algumas horas de um só dia, geralmente dentro da casa, com exceção do segundo ato, que se passa do lado externo.

Para Elias (2015), o primeiro ato funciona como um prólogo. A cena se sucede durante a madrugada em que Liubov retorna à Rússia para tentar retomar a sua antiga vida. A encenação ocorre no quarto das crianças, cômodo da antiga casa da fazenda, quando a propriedade é apresentada em seus vários significados, por intermédio das perspectivas de Liubov, Ánia, Lopakhin e Trofimov.

176
De acordo com Pavis (20 I I), o segundo ato corresponde ao agon - ou seja, o princípio que marca a relação de conflito entre os protagonistas. Transcorre no campo, onde se pode ver "o caminho que conduz à propriedade de Gaiev. [...] ali começa o jardim das cerejeiras” (ELIAS, 20I5, p. II4) em um final de tarde, num dia entre os meses de maio e agosto. Neste momento o público tem ciência dos conflitos de valores entre as personagens e o esforço que cada uma delas faz, em ações fora do palco, para salvar o jardim das cerejeiras.

O terceiro ato ocorre no dia 22 de agosto em uma festa, à noite, realizada no salão da casa de Ranievskaia e Gaiev. Justamente no mesmo momento em que, na cidade, a propriedade está sendo leiloada. Deste modo, este ato corresponderia ao phatos ${ }^{14}$, ou seja, "à peripécia da forma trágica tradicional" (ELIAS, 20I5, p. II5). Enquanto na cidade acontece o leilão da antiga casa, Liubov estranhamente está realizando uma festa aos seus convidados. Este ato encerra-se com o anúncio de Lopakhin, confirmando que é o novo dono do jardim das cerejeiras em um discurso que transita entre momentos de orgulho e a culpa por sua atitude.

Enfim apresenta-se o quarto e último ato, o momento de epifania em que a ação é vista sob um novo e irônico ponto e vista. É outubro, em pleno outono, quando

${ }^{14} \mathrm{Na}$ experiência do espectador, o phatos corresponde ao sentimento de dó, compaixão ou empatia criados pela qualidade do texto, ou da representação. 
ainda se tem um pouco de sol, mas já bastante fraco. A ação transcorre no mesmo ambiente em que se inicia o espetáculo, no quarto das crianças. Liubov e as demais personagens estão deixando $\circ$ jardim das cerejeiras enquanto ouvem $\circ$ barulho de madeira derrubada. Lopakhin destrói o centenário jardim para construir um loteamento veranista e lucrar com a propriedade.

Este final carrega uma intensa e provocativa imagem metafórica. É outono, ou seja, a estação que geralmente é associada ao final de um ciclo. Firs, o personagem octogenário, aquele que ainda tem a memória das tradições do passado, é literalmente trancado e esquecido na casa velha que será demolida. Afinal a casa é fechada e, ao fundo, percebem-se sons cortantes de madeira seca atingidas pelas machadadas que se assemelham ao som de pregos sendo fixados. Assim, pode-se dizer que a casa seria um caixão e a presença de Firs, imóvel como um utensilio centenário em meio e essa somatória de imagens, reforça ainda mais a metáfora da morte que Tchekhov imprime em seu texto.

\section{I.2 - A encenação de 0 Jardim das Cerejeiras (198I)}

De maneira a compreender o processo de concepção do espetáculo O Jardim das Cerejeiras (198I), é fundamental relembrar brevemente alguns elementos presentes na montagem anterior do CICT: $A$
Conferência dos Pássaros (1979). Como um dos focos da pesquisa era a relação entre o ator e os espectadores, o trabalho neste processo investigativo sugeriu um novo caminho, deixando o artifício teatral para trás. Estavam preocupados com o que o diretor chamou de "o essencial", ou seja, o despojamento de apetrechos desnecessários à encenação.

Apresentado em um palco nu, com exceção de tapetes orientais colocados no chão do palco, que delimitavam o espaço de representação teatral e aqueles fixados no fundo do espaço de representação, os atores assumiram vários papéis: às vezes eles eram os pássaros e, em outros momentos, eles encenavam vários outras personagens da história, dentro do enredo contado pelo narrador. Foram utilizados, também, fantoches de aves e máscaras balinesas e, para identificação das personagens, os atores em cena se utilizavam de gestos distintos que permitissem uma rápida identificação com a personagem.

No processo de O Jardim das Cerejeiras (figura 37), como exposto anteriormente, uma das principais preocupações da direção foi a fidelidade ao texto de Tchekhov e, consequentemente, estar atento à precisão, uma vez que essa era uma das qualidades essenciais do autor. Deste modo decidiram que o texto adaptado ao francês fosse exatamente tão forte e realístico quanto o original. Uma questão que vale ser ressaltada 
na encenação de Brook foi o ritmo proposto, que se contrapunha ao criticado "ritmo ralentado" (ELIAS, 20I5, p. 177) da montagem de Stanislávski no Teatro de Arte de Moscou, revelado por Meyerhold em carta a Tchekhov.
Brook definiu a divisão do espetáculo por quadros e não por atos, conforme o texto de Tchekhov. Segundo Elias (20I5), para os espectadores ficava mais evidente a rapidez com que a cena era realizada, a não fixação de detalhes e um aspecto de "inacabamento" que causava

Figura 37 - Cartaz de O Jardim das Cerejeiras (198I) direção de Peter Brook no Thêátre des Bouffes du Nord.

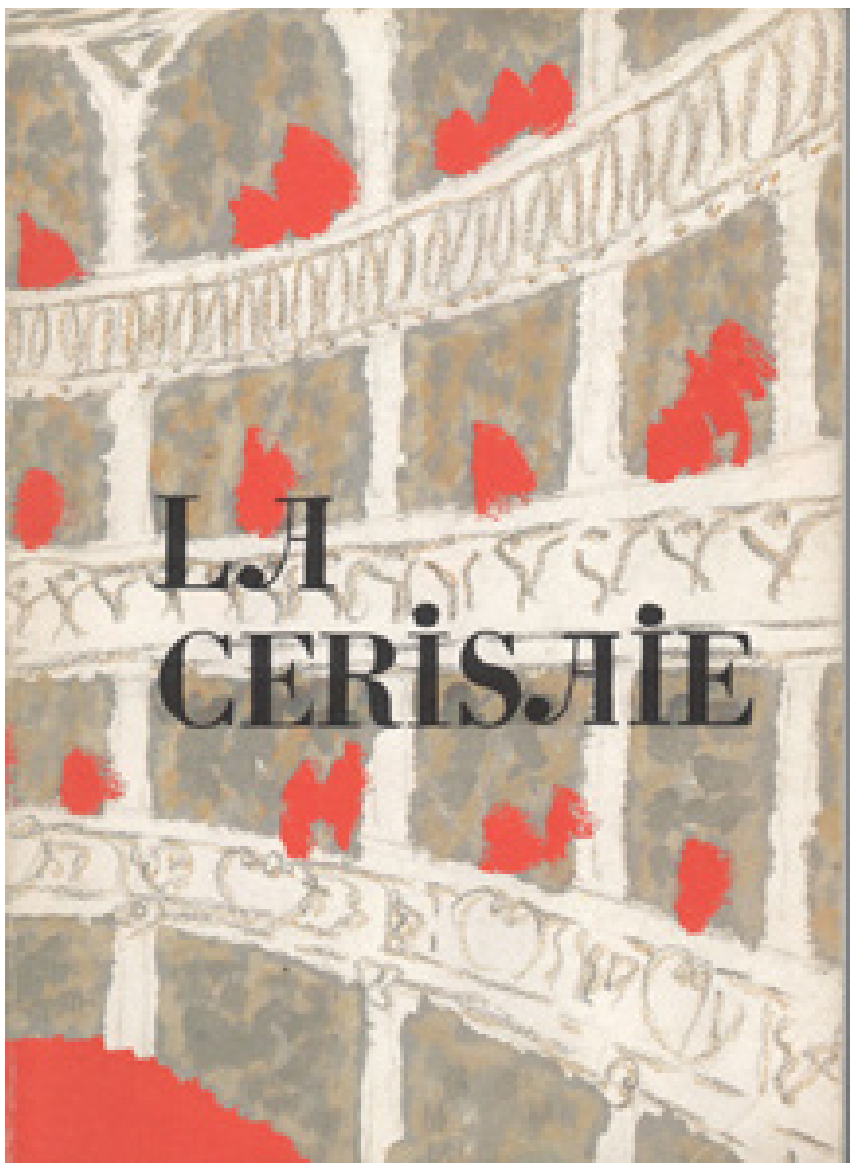

Fonte:Acervo do autor (2012) 
a impressão de que os quadros se precipitavam uns sobre os outros. A aceleração era fundamentalmente notada pelo ritmo, por vezes frenético, com que os atores pronunciavam suas falas, sobretudo Lopakhin interpretado por Niels Arestrup.

Vale ressaltar que o entendimento de ritmo é uma questão relevante para compreender essa concepção de Brook. Além da aceleração das falas, o ritmo da organização do espaço e a cadência da movimentação espacial são fundamentais para a determinação do aspecto mais próximo da comicidade pretendida no espetáculo. É importante destacar também que, quando Brook decidiu montar o espetáculo na primavera de 198I, o CICT havia renovado completamente o seu quadro de atores, permanecendo somente entre eles sua esposa, Natasha Parry, que interpretou Liubov.

Foi o momento em que se estabeleceu o princípio de que qualquer intérprete poderia encenar qualquer personagem, rompendo com os padrões de que seria importante para o sucesso do espetáculo que houvesse uma concordância entre a aparência física da personagem com o tipo físico do ator. Conferindo, portanto, uma liberdade para que o artista pudesse ressaltar as suas qualidades independente de etnia e idade. Hunt e Reeves (1995), no texto Director in perspective, indicam que houve um processo um pouco conturbado no início da montagem: alguns atores se recusaram a interpretar alguns papeis, ao considerar que o papel era pequeno demais.

Dois dos atores que participaram dessa montagem foram: Michel Piccoli que realizou Gaev e o experiente cômico Robert Muzeau que interpretou Firs. Muzeau, que já estava aposentado disse que esperou por quase sessenta anos para fazer Tchekhov, e aceitando o papel com bastante satisfação e muita gratidão. Deve ser destacado, também, que foi neste espetáculo que tivemos a presença de uma nova colaboradora, responsável pelos cenários e figurinos da peça, a designer Chloé Obolensky.

É importante frisar que Sally Jacobs, a parceira anterior de Brook, que trabalhou com o diretor até 1979 no trabalho de A Conferência dos Pássaros, vivia nos Estados Unidos desde 1970. Como já estava trabalhando com o diretor há muitos anos, depois desse espetáculo, decidiu se desvincular de Brook para não tornar sua carreira totalmente dependente do sucesso do diretor. Desse modo o CICT estava totalmente desprovido de designer de cenografia e trajes de cena, momento este em que decidiram realizar seu próximo processo de montagem.

A cenógrafa Chloé Obolensky foi contactada para fazer parte da equipe, pois havia acabado de publicar seu livro O Império Russo: um retrato em fotografias (1979) que reunia fotografias antigas da família de seu marido. 
Naquele momento Brook imediatamente percebeu que a designer seria ideal para evocar o universo russo do início do século $X X$ pretendido para o espetáculo $O$ Jardim das Cerejeiras no Théâtre des Bouffes du Nord. De acordo com Hunt e Reeves (1995), os ensaios do espetáculo duraram dez semanas, aproximadamente dois meses. E, no primeiro dia, Brook ofereceu para a equipe um luxuoso jantar russo para que os artistas pudessem se ambientar ao clima proposto.

Deve-se destacar que, na montagem, houve um intenso respeito às rubricas propostas por Tchekhov e, mesmo com a adaptação do texto, havia uma grande fidelidade à versão do autor. Desse modo os atores deveriam seguir exatamente as indicações que eram oferecidas pelo autor, aproximadamente oitenta anos antes da realização da montagem. Segundo Georges Banu (200I), Brook indicou que haveria um grande problema de atuação se a peça não tivesse uma expressiva vitalidade e rompesse com a visão de um texto languido e melancólico, usualmente utilizada nas encenações das peças do autor russo.

Nessas personagens há um evidente desejo de se mostrarem vivas, o que afastou a ideia de que o desgaste da classe social corresponderia, neste caso, ao desgaste do ser humano. Assim, a atuação teve uma uniformidade e uma sintonia significativas, que tornava perceptível ao público a interação entre os atores, mesmo em cenas em que eles só passavam uns pelos outros. Mesmo com um enfoque mais leve, trabalhou-se em uma constante corrente de sentimentos relacionados com as perdas e as esperanças frustradas que efetivamente eram sugeridas pelo texto. Não havia, dessa forma, qualquer indulgência emocional, mas uma expressiva profundidade de sentimentos.

Sobre o processo de construção cênica, conforme os demais espetáculos que antecederam essa montagem do grupo, a improvisação foi determinante na concepção da encenação. Durante os ensaios os atores começaram a utilizar todos os espaços do teatro: balcões, janelas e escadas. Logo, todo o teatro se tornou vivo para o grupo, como relatou Natasha Parry (apud TODD; LECAT, 2003), que encenou Liubov Ranievskaia. Esse depoimento da atriz, expresso no livro The Open Circle (TODD; LECAT, 2003), revelou que a familiaridade com o espaço contribuiu sobremaneira para a comunicação estabelecida em cena, o que contribuiu, definitivamente, para que o Théâtre des Bouffes du Nord se tornasse também importante na montagem.

Assim como ocorre no texto, a montagem de Brook se passa, também, em um só lugar: o teatro. Fato este que permitiu estabelecer, ao espetáculo, uma relação de interposição entre a vida e o teatro, uma vez que optou por tornar a casa dos atores na amada e degradada propriedade de Ranievskaia. Nestes termos, evidencia- 
se a metalinguagem estabelecida pela encenação, uma vez que a casa dos atores -o Théâtre des Bouffes du Nord -, era o local da propriedade do jardim das cerejeiras - casa das personagens tchekhovianos; e ambos eram espaços em ruínas, tanto a casa degradada e sagrada da família de Liubov quanto a sede dos atores.

De modo a reforçar a posição de destaque do espaço teatral na peça, as rampas, as escadas laterais, as paredes manchadas, as portas, os corredores entre as arquibancadas, a galeria circular por trás delas, os balcões

Figura 38 - Cena de 0 Jardim das Cerejeiras (198I) em que se percebem as paredes descascadas da casa de Ranievskaia. nos andares superiores, ou seja, todos elementos da arquitetura do próprio teatro foram incorporados à montagem. $O$ aspecto degradado das paredes descascadas que Brook encontrou quando decidiu se estabelecer nesse local, se encaixou perfeitamente com as ruínas ambientadas na casa deteriorada do texto de Tchekhov, o que estimulava a imaginação do espectador a se colocar naquela situação, conforme evidencia a figura 38.

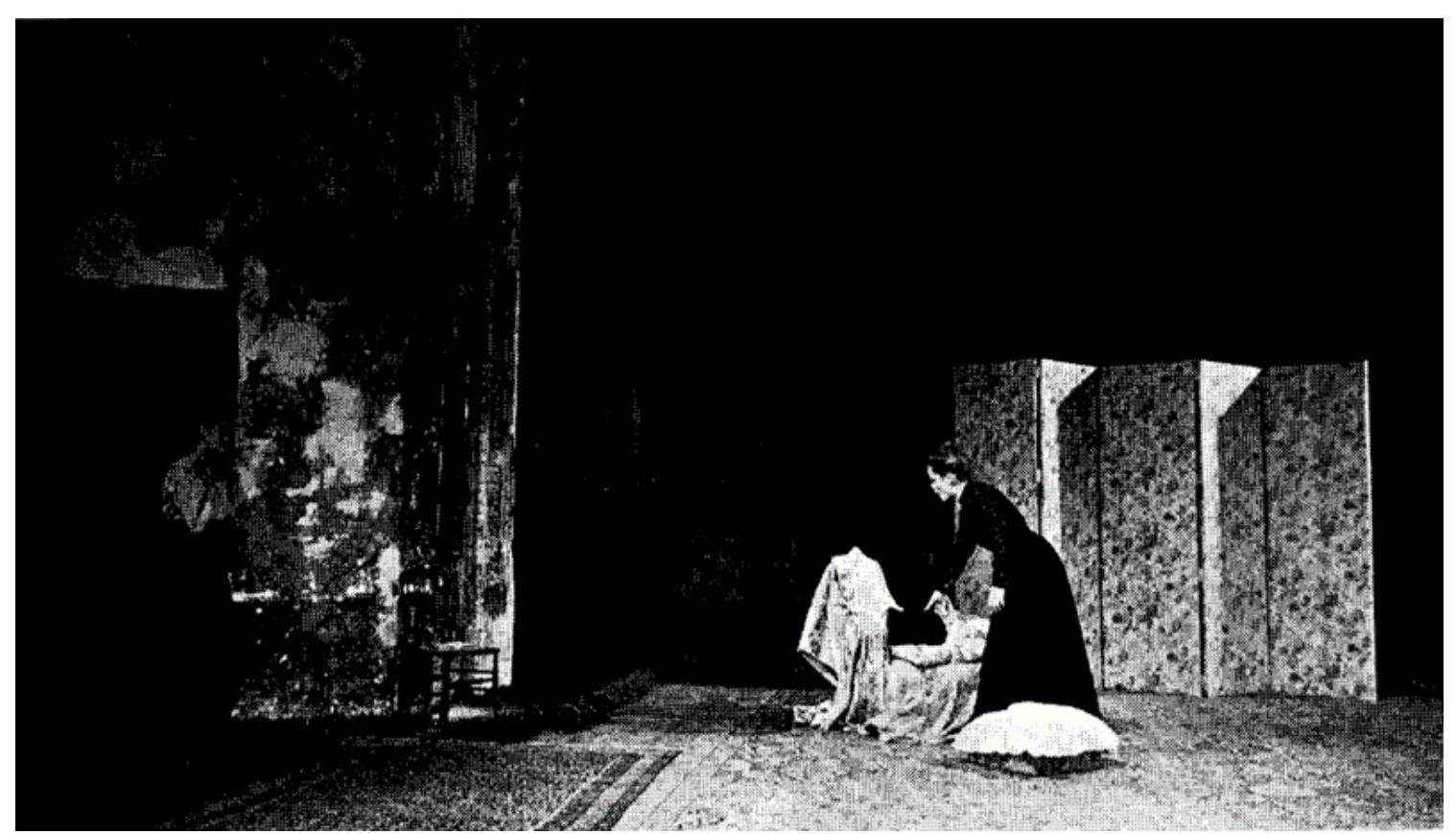

Fonte: Hamon; Picon-Vallin; Nedelco-Patureau (1985, p. 277). 
Devido ao protagonismo que o espaço cênico assumiu nessa montagem, a discussão sobre este tema deverá continuar sendo explicada a seguir, quando se esmiuçará a questão da conformação da cenografia e dos trajes de cena do espetáculo de forma mais aprofundadas. Contudo, ainda sobre a direção do espetáculo, é significativo identificar que a realizada por Brook caminhou no sentido de caracterizar seu teatro com um processo de eliminar de cena tudo o que era supérfluo, em busca de uma simplicidade associada à profundidade da representação.

Hamon, Picon-Vallin e Nedelco-Patureau (1985), em seu texto La Cerisaie et la vitalité tchekhovienne, ressaltam que, nesse trabalho do encenador, é possível identificar traços das lições espirituais na encenação de modo que há uma procura por seguir com um fluxo livre e continuo de energia em cena, ao se estabelecer um constante intercâmbio de energias entre atores e espectadores de modo que a ocorrer uma corrente de troca contínua. $O$ público se integra à encenação e participa do trabalho proposto pelo estímulo à sua imaginação, permitindo com que faça parte do processo de construção cênica.

Dessa maneira, o espaço teatral estabelece um sentido metalinguístico no espetáculo, criando um elo entre a vida fictícia das personagens e a situação vivenciada pelo grupo. Essa superposição sutil de linguagens se constitui pela perspectiva de que o espaço do Théâtre des Bouffes du Nord é tanto a casa em ruínas, amada por Liubov Ranievskaia, quanto o espaço igualmente amado e degradado que serve como sede do grupo teatral. Nesse contexto, a propriedade da família aristocrata se estendeu às dimensões da realidade dos espectadores, pois sua arquitetura seria coincidente com todo 0 espaço teatral.

O espaço interior da casa da peça é refinado, como também é o espaço vazio do teatro. Não existem móveis, cortinas ou quaisquer outros elementos. Segundo Hamon, Picon-Vallin e Nedelco-Patureau (1985), o espaço é justamente apresentado vazio como forma de reforçar a intensa história de desapego que é retratada em $O$ Jardim das Cerejeiras, escrita por Theckhov quase à beira da morte. Nesse jogo cênico Brook estabeleceu que o pomar com o esplêndido jardim das cerejeiras fosse construído na imagem mental do espectador, ao longo da encenação. Para os autores supracitados, essa construção imagética constrói uma relação dupla: representa tanto a imagem de um símbolo de felicidade, como também uma projeção visual do silêncio, ao qual certas antigas meditações orientais conduzem ao final do seu estágio de observação.

Durante a encenação havia uma constante: eram criadas relações entre espectadores e atores para que se tornassem íntimos uns dos outros. Por meio 
dos jogos de improvisações, realizados no período de ensaios, a encenação conseguiu envolver a plateia para que se tornasse parceira das personagens em diferentes situações. $O$ contraste estabelecido entre a comicidade de algumas circunstâncias e a densidade de uma realidade obscura da existência humana, permitiu que os espectadores não assistissem ao espetáculo em posição de juízes. Eram simplesmente seres humanos refletindo sobre uma história que trazia a ponderação sobre a questão da impermanência da existência humana no mundo.

\section{I.3 - O espaço de representação e os trajes de cena de $O$ Jardim das Cerejeiras}

A encenação ocorre em todo o teatro, porém predominam as cenas no espaço central de representação do Théâtre des Bouffes du Nord. A maior exceção é o quarto ato, quando se descentraliza e o espaço se abre tanto na vertical quanto na horizontal, ocupando as laterais, o alto e o fundo do palco e a frente do teatro. É importante evidenciar que um elemento presente nas pesquisas de Brook, desde as suas investidas nas viagens à África que contribuiu para o protagonismo do espaço nesta encenação, é a presença do tapete em cena - ou seja, os espetáculos do carpet show.

Os tapetes utilizados em $O$ Jardim das Cerejeiras são os mesmos de $A$ Conferência dos Pássaros, porém sua presença adquire novas proporções, uma vez que não foram colocados como anteriormente em que delimitavam a área de representação como pode-se perceber na figura 39. Brook solicitou que o espaço de representação fosse despojado de cenários, exceto pelos tapetes persas gastos que eram lançados pelo chão. Sendo assim seriam os únicos resquícios de que a casa de Ranievskaia havia sido uma casa aconchegante e reconfortante, apesar da sua degradação. 
Figura 39 - Cenas do segundo ato, em que é possível perceber a estruturação dos tapetes em cena.

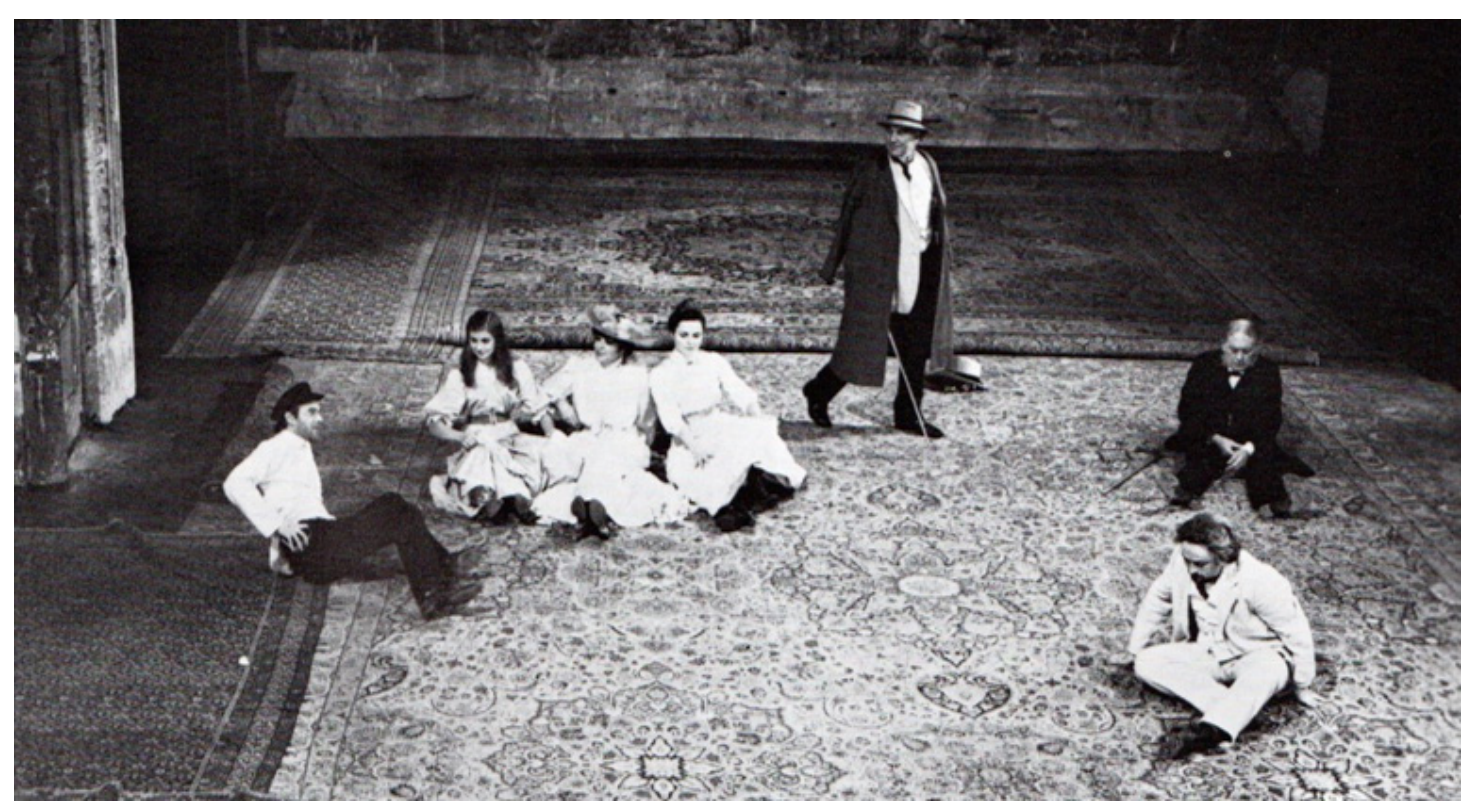

Fonte: Hamon; Picon-Vallin; Nedelco-Patureau (1985, p. 280)

No espaço cênico desta obra, os tapetes tocavam as paredes laterais do teatro e percorriam quase todo o espaço. Essa foi uma das formas que a cenógrafa encontrou para associar o teatro à imagem da casa. Como os tapetes floridos tocavam tanto as paredes do teatro como os pés do público, eles deixaram de ter a função de restringir o espaço de atuação e se tornaram responsáveis por reforçar a imersão dos espectadores na velha propriedade da família. Fato este que foi reforçado com as personagens falando do balcão, movimentando-se constantemente por todo o teatro e por entre o público.
Outro aspecto fundamental no processo artístico de Brook é o estímulo à imaginação do público. Uma das maneiras mais eficientes encontradas neste espetáculo é a indicação da imagem do jardim, como se estivesse atrás do público. Os atores se referem a ele como se estivesse atrás da plateia, o que força que cada um estabeleça em seu imaginário o que seria o jardim. Os poucos móveis, os biombos, que fazem as divisórias dos ambientes da residência, o armário centenário, os tecidos desbotados, as paredes descascadas denotam uma casa quase vazia, antiga e decadente. 
Durante o primeiro ato da peça, os biombos e os tapetes floridos com poucos móveis compõem o ambiente de representação. Os atores estão, na maior parte do tempo, mais próximos do nível do chão (figura 40) sentados diretamente nele ou sentados nas poltronas, em seus braços, ou em cadeiras. Deve-se atentar que, para Tchekhov a ação transcorre no quarto de criança, ou seja, um lugar da infância, das brincadeiras, das memórias, do passado com o qual os personagens se reencontram. $\mathrm{Na}$ encenação, boa parte da associação com o universo infantil é realizada pela movimentação dos atores nesse plano baixo e mais horizontalizado.

Figura 40 - Cena do primeiro ato de O Jardim das Cerejeiras (198I) direção de Peter Brook no Thêátre des Bouffes du Nord.

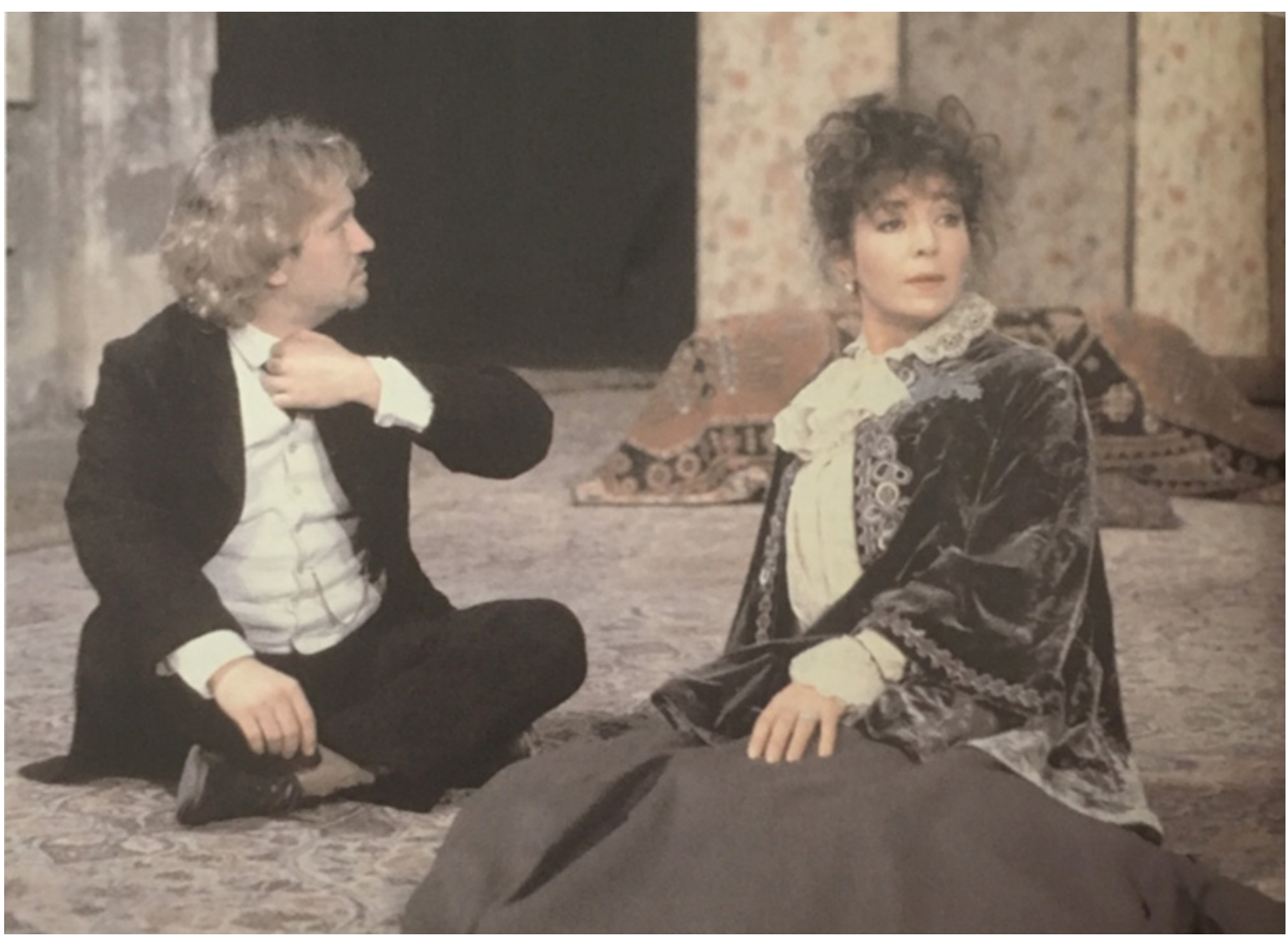

Fonte:Todd; Lecat (2003, p. 80). 
No segundo ato (figura 4l) a ação se passa em um local externo à residência, entre a casa e o jardim. A solução adotada pela encenação é concentrar a área de representação na parte central, criando um retângulo sem qualquer elemento além dos tapetes. Este é o momento em que os atores exercitam a imaginação do público, pois o jardim é recorrentemente indicado nas áreas do entorno, nas costas do público, por meio da indicação de foco visual dos atores em cena.

Figura 4I - Cena do segundo ato de O Jardim das Cerejeiras (198I) direção de Peter Brook no Thêátre des Bouffes du Nord.

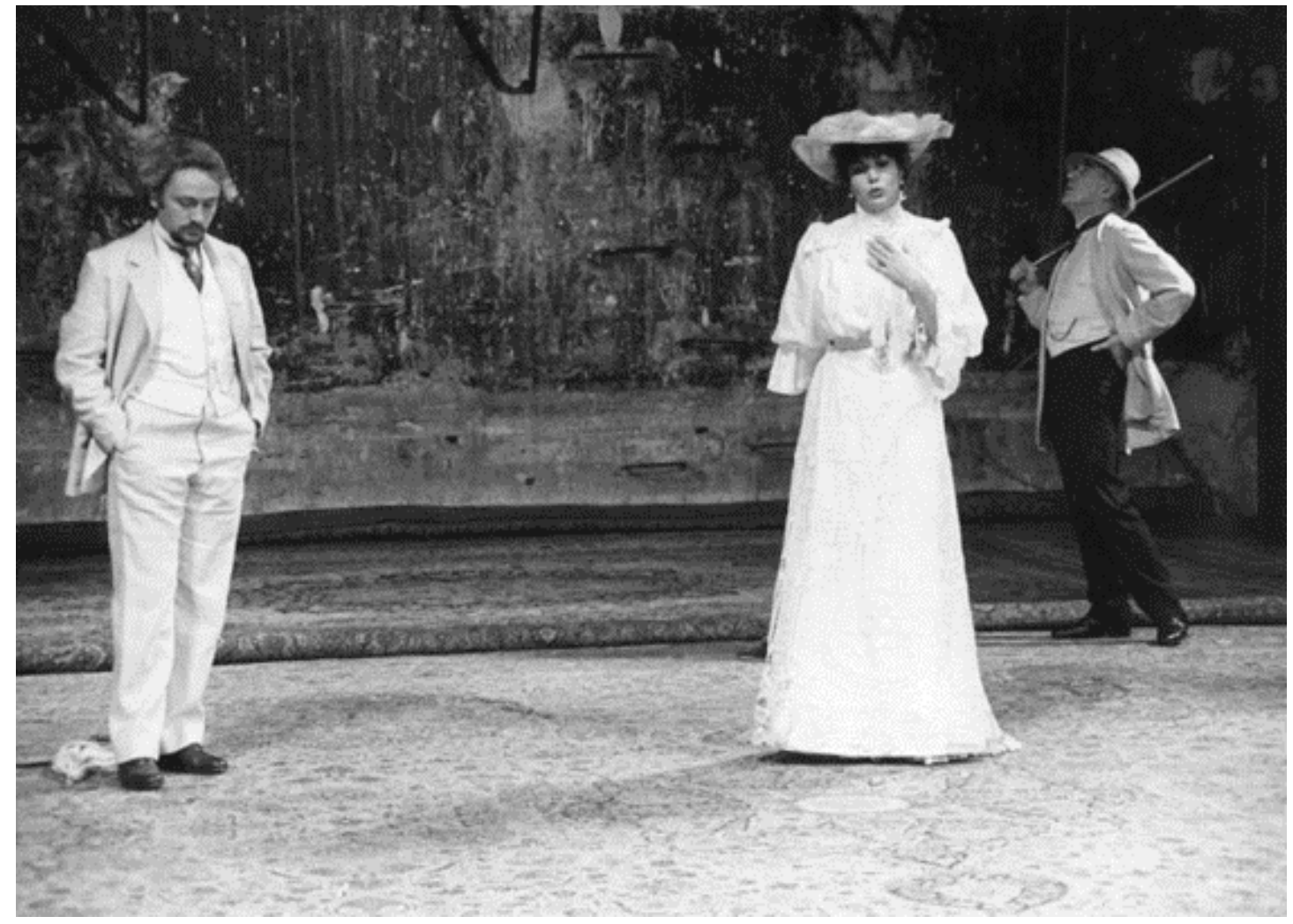

Fonte:Treatt (1981). 
No terceiro ato a ação é novamente concentrada no retângulo inicial, porém, de modo distinto dos demais atos, em que se vê todo o espaço cênico. Até este ato, não havia quaisquer móveis, cadeiras ou sofás para que as personagens se sentassem, exceto um tapete enrolado que compunha estranhamente a cena no primeiro ato. Neste momento, sua configuração é intencionalmente fragmentada, pois alguns biombos são posicionados para seccionar o retângulo da representação, formando, assim, alguns corredores. No entanto não se separam os espaços de representação completamente, é permitido que se veja a ação da festa que ocorre ao fundo, caracterizada pela movimentação dos atores (figura 42).

Figura 42 - Cena do terceiro ato de 0 Jardim das Cerejeiras (I98I) direção de Peter Brook no Thêátre des Bouffes du Nord.

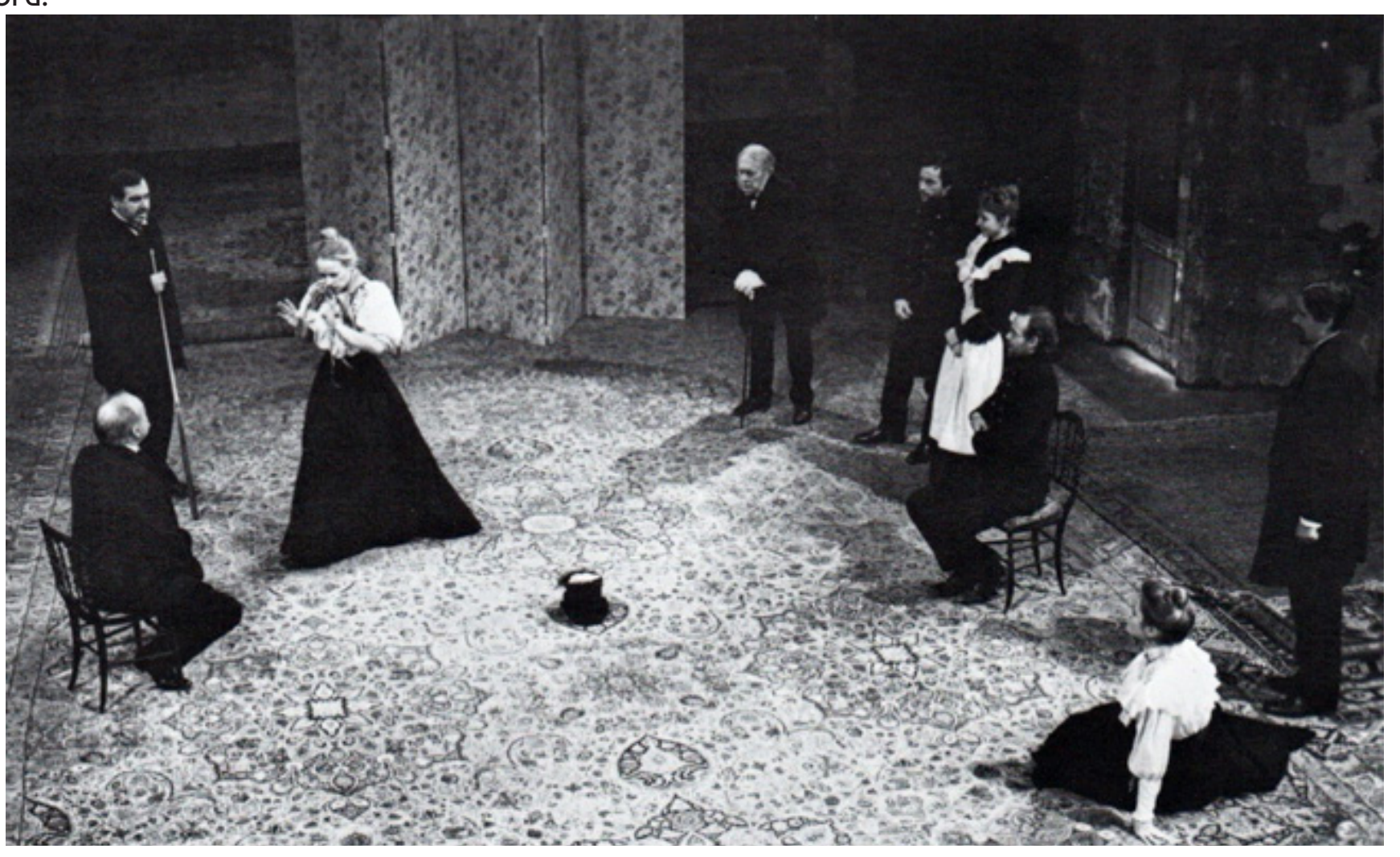

Fonte: Hamon; Picon-Vallin; Nedelco-Patureau (1985, p. 28I). 
Vale destacar que é durante esse ato que Lopakhin anuncia a compra do jardim das cerejeiras. $O$ ator se movimenta de modo bastante irregular pela área de representação, andando da frente ao fundo do espaço por diversas vezes. Até o momento em que bate com os braços no biombo do fundo que delimitava o espaço de representação. $O$ tapete que cobre o biombo balança e cai de costas sobre outro deles, derrubando-os. Ouvese um barulho de grandes proporções que evidencia um dos momentos mais impactantes da montagem, pois o efeito criado com o desabamento dos biombos, simbolicamente prenuncia o que irá acontecer à propriedade.

\section{inacabada.}

Figura 43 - Cena do quarto ato de O Jardim das Cerejeiras (198I) direção de Peter Brook no Thêátre des Bouffes du Nord.

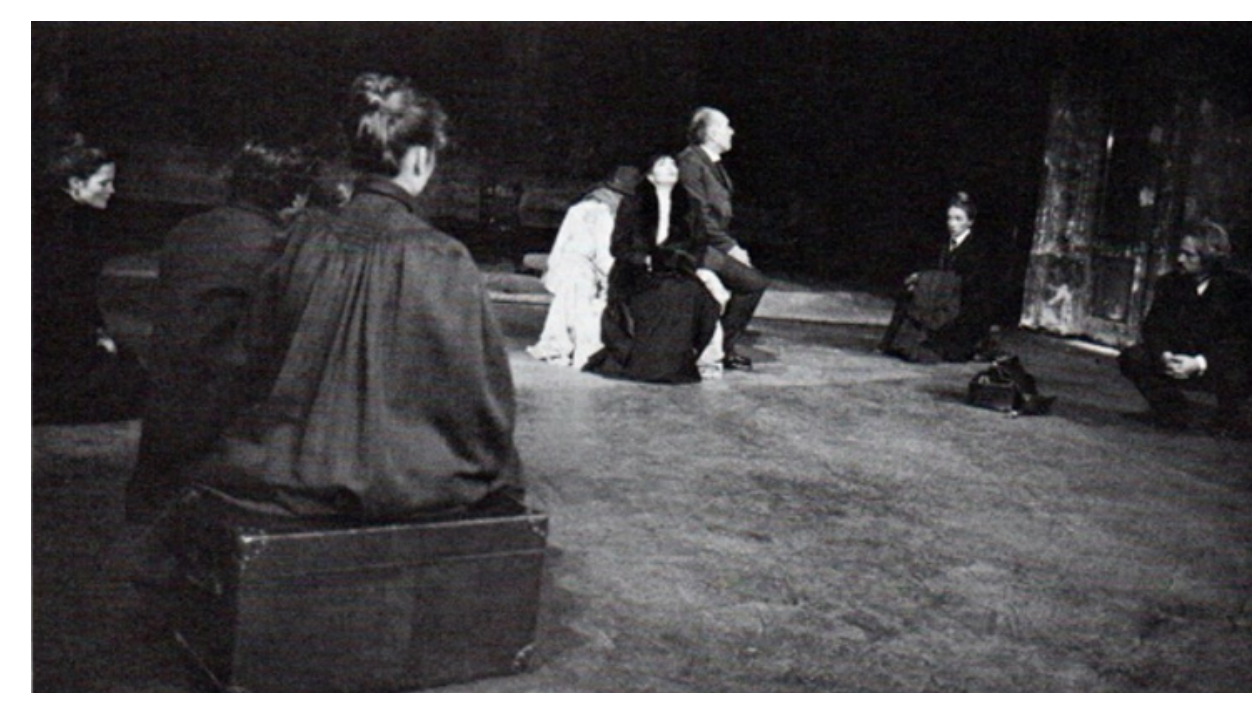

Fonte: Hamon; Picon-Vallin; Nedelco-Patureau (1985, p. 28I).
No quarto e último ato, o espaço se abre completamente. Os tapetes são removidos (figura 43), restando apenas um deles no chão, em segundo plano. Sobre ele percebese um amontoado dos outros tapetes enrolados, um pano e mais alguns objetos. Há malas espalhadas pelo com taças de champanhe. Ao fundo se vê um lençol pendurado e a poltrona sem banqueta está coberta por um tecido claro. A ação cênica é estendida para fora da área central de representação, utilizando-se bastante as rampas, as laterais frontais, um dos balcões superiores do teatro, as escadarias e um curioso buraco na parede de contorno irregular, que se assemelha a uma porta espaço e, sobre uma delas, encontra-se uma bandeja 
A imagem da ruína da casa e da iminente destruição do jardim está estampada definitivamente nas paredes e no chão do teatro, agora totalmente desnudados, despojados de quase todos os móveis e adereços. Resta apenas a poltrona, espécie de leito de morte, em que Firs, que fica "esquecido" na casa deixada para trás, se deita e dorme. É importante destacar a forma como Brook e os seus atores conceberam intencionalmente a movimentação das personagens em cena.

Conforme Elias (2015) expõe em seu livro, Está à venda o Jardim das Cerejeiras, à medida que a encenação avança, a movimentação parte do plano predominantemente baixo, com os atores bastante próximos aos tapetes no chão, para, a partir de metade do segundo ato até o final do terceiro ato, permanecerem em um plano médio, e finalmente no quarto ato, partirem para o plano alto, ficando assim, mais verticalizados e livres dos tapetes. No esquema abaixo que evidencia a composição do espaço (figura 44), é possível perceber a importância da ocupação espacial nesse espetáculo, em que o campo de representação ganha um evidente protagonismo.

Figura 44 - Esquemas do cenário do $1^{\circ}$ e $4^{\circ}$ atos de $O$ Jardim das Cerejeiras (198I) no Thêátre des Bouffes du Nord, desenhado por Larissa Elias a partir do ensaio escrito por Béatrice Picon-Vallin.

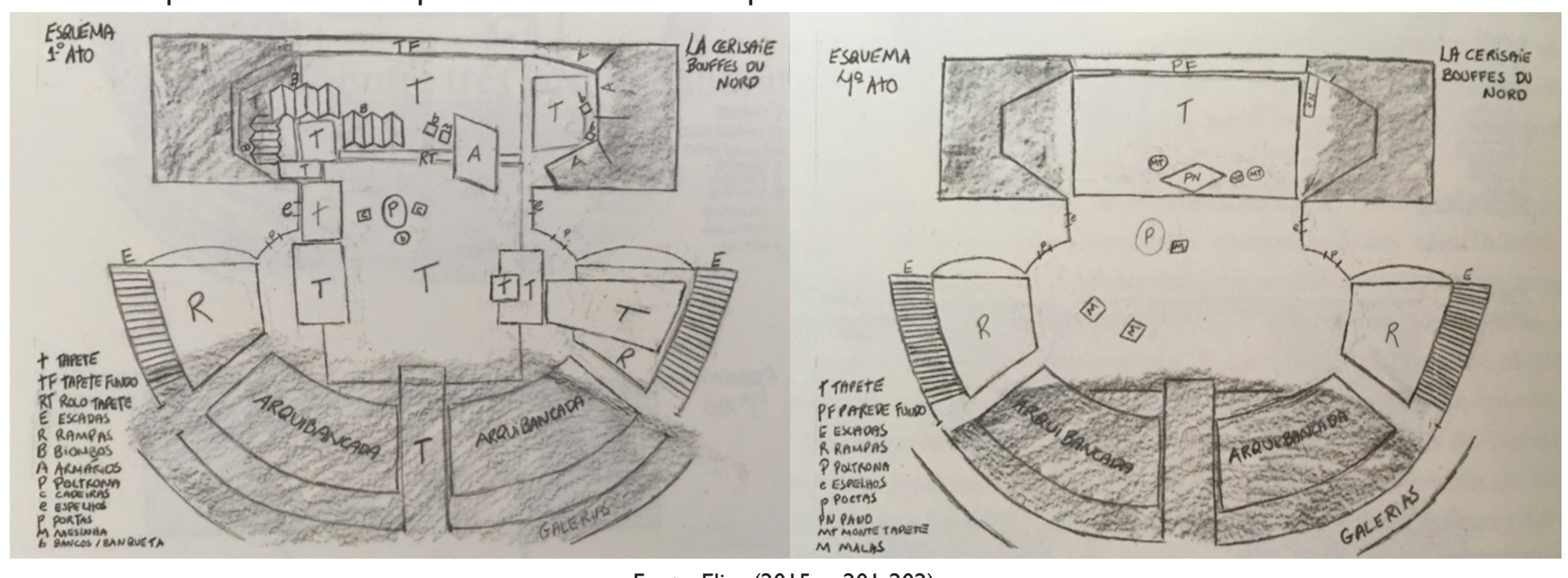

Fonte: Elias (2015, p. 20I-202). 
Para Hamon, Picon-Vallin e Nedelco-Patureau (1985)

o espaço cênico proposto era a personalização da residência decadente de Liubov. Sua estrutura, em todos os atos, parte de um evidente espaço vazio que era envolvido pelas paredes destruídas, ora remetendo a uma cor acinzentada da fuligem da destruição do bombardeiro, ora parecendo avermelhadas com vestígios de pinturas antigas do espaço cênico anterior a ocupação do grupo. $O$ piso se assemelhava a uma colcha de retalhos de tapetes orientais de diversos tamanhos, que se sobrepunham. Devido ao seu evidente desgaste, ressaltavam a degradação daquele ambiente.

Vale relembrar que os tapetes traziam também a memória do passado da montagem anterior de Brook. Além do resgate da memória dos próprios atores do grupo, é preciso considerar que a maciez do piso e a decoração com desenhos coloridos da cultura persa, para os autores supramencionados, evocavam um estágio de relaxamento que trazia a simbologia de um estilo de vida europeu da época, inspirados na cultura oriental. Além disso, compunham traços do espaço da infância, dos segredos e dos jogos infantis propostos pelo texto. Remetiam, ainda, a um passado antigo em que havia abundância de recursos financeiros, um passado mais distante das personagens, que resgatam memórias de quando eram crianças para se sentirem mais confortáveis com seu atual estado.
Deacordo com Hamon, Picon-Vallin e Nedelco-Patureau (1985), a proposta de Brook e Obolensky estabelece algumas relações espaciais que são extremamente significativas para a montagem. A escolha dos ambientes, o arranjo dos tapetes, a ausência de objetos cênicos em alguns momentos e sua presença em outros, ofereceu uma estrutura espacial que permitia a sobreposição de cinco tipologias espaciais: o espaço das festas; o espaço real; o espaço do imaginário; o espaço pessoal e coletivo; e, o espaço mental.

Em relação ao primeiro, das festas, era um espaço dinâmico e sempre composto por muitas personagens. Geralmente era representado por três corredores principais que se estabeleciam em cena e que permitiam a fruição das personagens pelas portas laterais do palco. O espaço real, em sua totalidade, era estabelecido pelo contato visual do espaço cênico que era composto pelo círculo do palco do Théâtre des Bouffes du Nord, pelos planos verticais utilizados pelos atores durante alguns momentos da encenação, pelas distâncias que os intérpretes deveriam percorrer, bem como pelo contato com o solo quando executavam as cenas no plano inferior. Também deveriam ser agregadas as percepções sonoras, como por exemplo o bater das portas do teatro, o barulho do biombo caindo, e as batidas finais com o corte das árvores.

○ espaço imaginário, assim como o anterior, era 
definido da mesma maneira: visual, tátil e sonoro. Porém, neste caso, um gesto indicava uma direção específica em relação ao formato da casa. Nesse contexto, a proposta de iluminação teve especial contribuição, pois no segundo ato, permitiu que a imaginação dos espectadores transformasse o espaço cênico no jardim externo à casa, dando a impressão de que os atores estavam a céu aberto. Foi, também, nesse tipo de espaço estabelecido pela encenação que se configurou o jardim das cerejeiras, evocado pelos atores e elaborado na mente do público.

Sobre o espaço pessoal e o coletivo, é relevante destacar que cada ator tem sua própria forma de estabelecer o espaço, o que, de certa maneira, reflete na construção do espaço corporal estabelecido pela personagem. Consequentemente, sofre influência tanto da composição corporal do artista como da maneira como seu traje de cena é composto.

\section{Como exemplo é possível citar:}

A falta de jeito de Epikhodov, o desejo de Douniacha de ocupar mais espaço do que ela pode, empurrando a barriga para frente e puxando a cabeça para trás, proporciona a contração da sua voz, e a faz tremer como uma boneca. Alguns acessórios podem contribuir para essa espacialização pessoal, como por exemplo Ranievskaia no segundo ato, está com um vestido longo, e sombrinha aberta ou esquecida no chão, bolsa vazia e a personagem largada ao chão acentua sua importância e a tendência de se espalhar constantemente.

Ranievskaia é o pólo de atração, às vezes fixo, às vezes móvel, do grupo que se move de acordo com ela. $A$ partir dela outros centros surgirão. [...] A variação dos centros, sua natureza, seu lugar, seu nível (em pé, sentado, ajoelhado, nas galerias, etc.) cria múltiplos círculos mais ou menos ampliados ou perfeitos que dobram, incluem ou cruzam as superfícies semicirculares do palco e da sala em vários lugares. Assim, Ranevskaia sentada no pufe central gera uma figura circular que inclui espaço e o primeiro plano do palco. No terceiro ato, quando o biombo cai e ela cai com dor em uma cadeira em primeiro plano, está no centro de um enorme círculo onde os espectadores estão com Pistchik em relação ao resto da casa que a queda descobre ao fundo, em pé, silenciosa. O círculo, em sua mobilidade, figura essencial da cena Brookiana, concentra, além de uma energia teatral, toda a carga das relações dentro da família, é esse espaço familiar permanente ao qual o espectador está associado.

[...] Finalmente, a maneira como Brook transforma a interpretação íntima dos personagens tchecovianos no processo de jantar amplia seu espaço pessoal e destaca o ator por trás do personagem, cara a cara com o público. Lopakhine e seu fermento 
(Ato I), Liubov e seu café (Ato I), Charlotte e seu pepino (Ato II), Yacha e champanhe (IV) essas entradas de bebidas ou alimentos costumam ser feitas com o olhar voltado firmemente não para seus parceiros de cena, mas em direção à sala, dando à especificidade dos gestos de cada um a amplitude de outro espaço frequentado por ele, cabaré, salão parisiense, reboque ou escritório, que o define e onde o público é seu parceiro por um momento (HAMON; PICON-VALLIN; NEDELCOPATUREAU, 1985, p. 288).

Sobre o espaço mental percebe-se que este indica a posição estabelecida por cada personagem a cada cena que é apresentada ao público. Ou seja, este espaço retrata e configura a posição mental de cada um, conforme os grupos que são estabelecidos em cena. Por exemplo, a posição marginal do tio, constantemente retratada, no texto se configura espacialmente de forma estática ou dinâmica quando o tio circula por trás do alinhamento das três mulheres sentadas ao chão no segundo ato (figura 39).

Para os trajes de cena, que definitivamente contribuem para a construção visual do espetáculo e consequentemente para o espaço de representação, observa-se a escolha de uma composição fortemente vinculada ao momento histórico em que o texto foi escrito. Ou seja, os trajes (figura 45) se aproximam de confecções do final do século $X I X$ e início do século $X X$. Esta composição tem um forte embasamento histórico e foram desenhados por Obolensky com base no livro que havia escrito. 
Figura 45 - À esquerda vemos trajes europeus do início do século $X X$ e à direita cena do $2^{\circ}$ ato em que Natasha Parry traja um vestido branco bastante referenciado nas indicações ao lado.

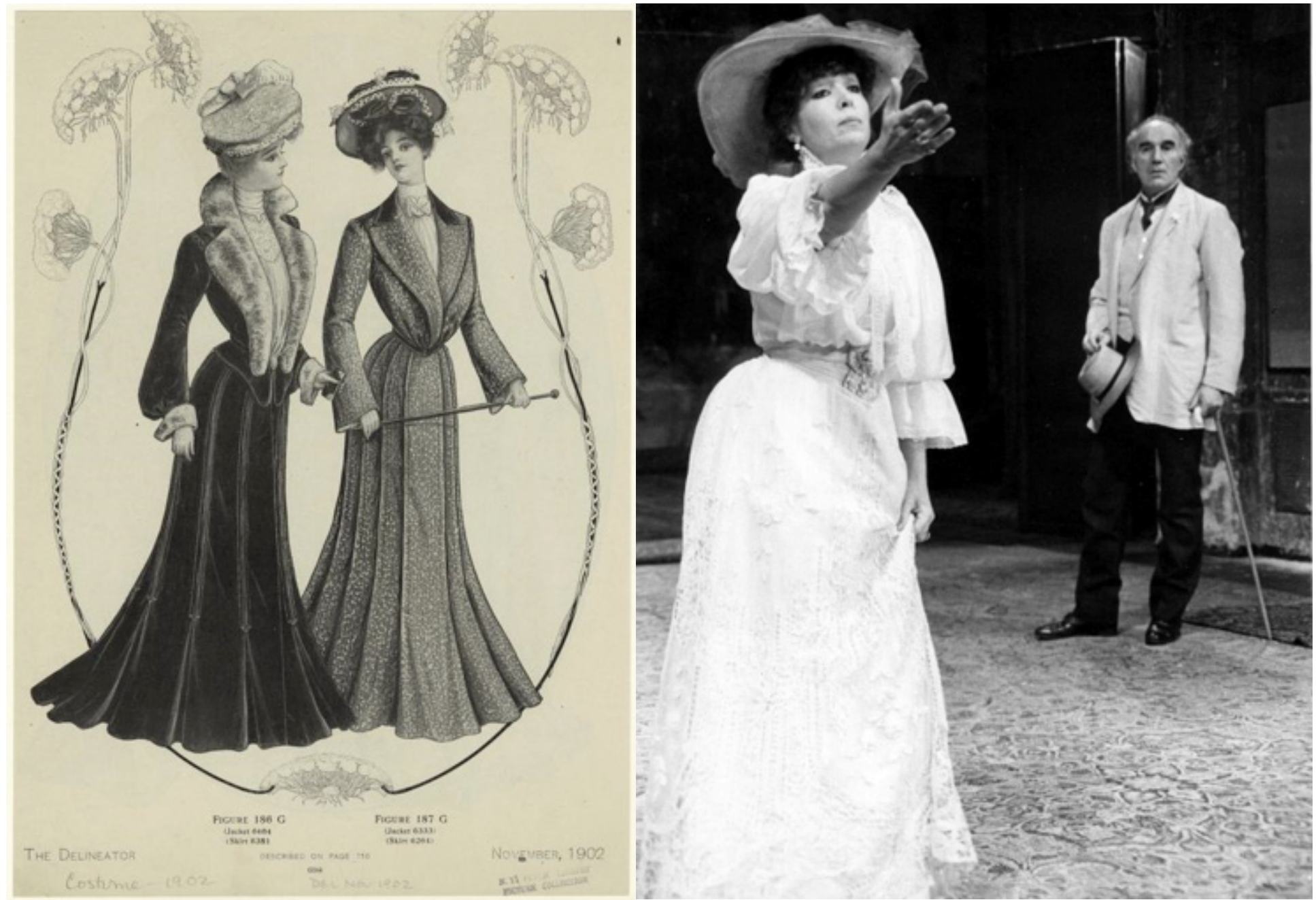

Fonte: Brook (I98I). 
A elegância e o corte das roupas se opõem à condição degradada do espaço cênico. A cenografia, composta pelos tapetes floridos e pelas paredes desbotadas, contrasta fortemente com as roupas lisas que combinam - claro e o escuro, com a prevalência do escuro. Há a predominância dos tons escuros, principalmente os pretos (no primeiro e terceiro atos), nos elegantes sobretudos, paletós, calças e saias, com alguns detalhes claros nos demais componentes do figurino. No segundo ato, determina-se um contraponto em relação aos demais trajes, pois sobressai uma paleta de cores calcada em tons claros, em contraste com alguns elementos em cinza e preto.

As estações do ano e consequentemente as sensações de frio e calor, também eram transmitidas tanto pelas formas e cortes dos trajes, quanto pela paleta de cores. Os assessórios contribuíam, de maneira similar, para que fosse possível estabelecer a leitura do clima. Ranievskala, por exemplo, no segundo ato que indica o período de verão, veste um longo vestido branco e um chapéu, que é agitado durante a encenação, de modo a indicar que se trata de um período de intenso calor (figura 45).

Ao relacionar os elementos presentes na concepção espacial do espetáculo 0 Jardim das Cerejeiras com a trajetória de Brook, fica evidente a permanência de alguns elementos de investigação do grupo, mesmo que a proposta tenha sido por uma maior fidelidade ao texto e ao contexto de Tchekhov. O que, para alguns críticos, poderia parecer um ruído frente ao processo de simplificação tanto da cena, quanto dos elementos visuais do espetáculo. Deve-se, porém, atentar que esta escolha adquiriu algumas características simbólicas.

O Théâtre des Bouffes du Nord intencionalmente revestido por tapetes floridos, além de incluir o espectador diretamente na cena de forma a participar ativamente do espetáculo, faz com que o espaço se torne também um dos protagonistas na ação. Ainda que se explore uma forma distinta da usual nos processos de Brook para o estabelecimento do jogo teatral, aproximando o ato cênico do espectador, é evidente a exploração da imaginação da plateia também nessa montagem. $O$ exercício da imaginação é substancialmente indicado pela sugestão que os atores fazem do jardim das cerejeiras que, em momento algum, é representado em cena.

Outro elemento de permanência na pesquisa teatral de Brook é a concepção do espaço vazio. Mesmo que o Théâtre des Bouffes du Nord tenha se tornado parte da encenação, a determinação de poucos elementos cenográficos no espaço interior da casa reforça o conceito primordial na concepção cênica brookiana que utiliza a imaginação do espectador como parte ativa da encenação. Nessa condição há uma evidente 
alteração da proposição espacial do espetáculo, o qual, definitivamente, se estabelece como um espaço simbolista, uma vez que 0 teatro, por meio da metalinguagem proposta, se torna, em sua totalidade, a casa abandonada dos aristocratas.

Contudo, ao compreender que os trajes de cena influenciam diretamente na composição espacial, observa-se que existe uma reprodução realista do período em que se estabelece a ação cênica proposta por Tchekhov. Uma vez que há indícios e relatos do próprio encenador evidencia-se que a escolha da nova cenógrafa e figurinista do grupo foi embasada na publicação do seu livro sobre registros fotográficos históricos. Deste modo, compreende-se que houve uma evolução no sentido de uma proposta que primava pela simplificação cênica, mas que não se completa em todos os elementos visuais do espetáculo.

\subsection{AS ORIGENS DA MONTAGEM DE A TEMPESTADE (1990)}

Em 1990, depois de realizar um de seus maiores trabalhos - Mahabharata, Brook iniciou um processo diferente. Já havia realizado, no palco do Théâtre des Bouffes du Nord uma temporada de músicas e peças sul-africanas outra em comemoração ao bicentenário da Revolução Francesa e, também, sobre o ano dedicado à celebração dos Direitos Humanos. Sobre esse novo momento, Brook (2005, p. 87) esclarece que:
Senti então a necessidade, tanto para o grupo de atores como para mim, de tomar um rumo totalmente novo e deixar para trás todas aquelas imagens do passado que haviam se tornado uma parte tão forte de nossas vidas. Eu andava interessado nas estranhas e nebulosas relações entre o cérebro e a mente, e após ler um livro do médico Oliver Sacks chamado 0 homem que confundiu sua esposa com um chapéu, vislumbrei a possibilidade de dramatizar esse mistério por meio dos padrões comportamentais de certos casos neurológicos. Nosso grupo ficou muito interessado no novo campo de trabalho que se abria.

Apesar do grande interesse que tinham nessa pesquisa sobre a mente humana, os integrantes do grupo precisavam de tempo para aprofundarem os estudos sobre os comportamentos neurológicos e desenvolver as investigações necessárias ao novo espetáculo. Além disso tinham a responsabilidade prática de manter a companhia teatral em atividade, bem como, o espaço do Théâtre des Bouffes du Nord funcionando. Desse modo, iniciaram a busca por um texto que se encaixasse com o processo investigativo do grupo internacional de atores. Queriam um texto que fosse capaz de oferecer, ao mesmo tempo, uma mensagem bastante valiosa ao público, que tivesse uma relação direta com as necessidades e realidades do período e, sobretudo, que inspirasse seus atores. 
Como não poderia deixar de ser, suas reflexões o conduziram diretamente ao autor com o qual Brook tinha bastante intimidade, William Shakespeare. O autor inglês continuava a ser "um modelo insuperável, e sua obra é sempre relevante e sempre contemporânea" (BROOK, 2005, p. 87). Decidiu realizar uma nova investida no texto $A$ Tempestade, em uma versão minimalista do clássico que foi traduzido para o francês, por Carriére, sob o título La Tempête. Tratavase de um espetáculo com o qual Brook já tinha uma certa intimidade. Seu primeiro contato foi em 1957, quando dirigiu uma versão com John Gielgud no papel de Próspero no Shakespeare Memorial Theater em Stratford-upon-Avon. Nessa experimentação o próprio Brook foi o responsável pelo desenho dos cenários e trajes de cena (figura 46).

Figura 46 - Desenho de Peter Brook para o traje de cena de Gonzalo e Cartaz da montagem de Peter Brook de A Tempestade (1957).

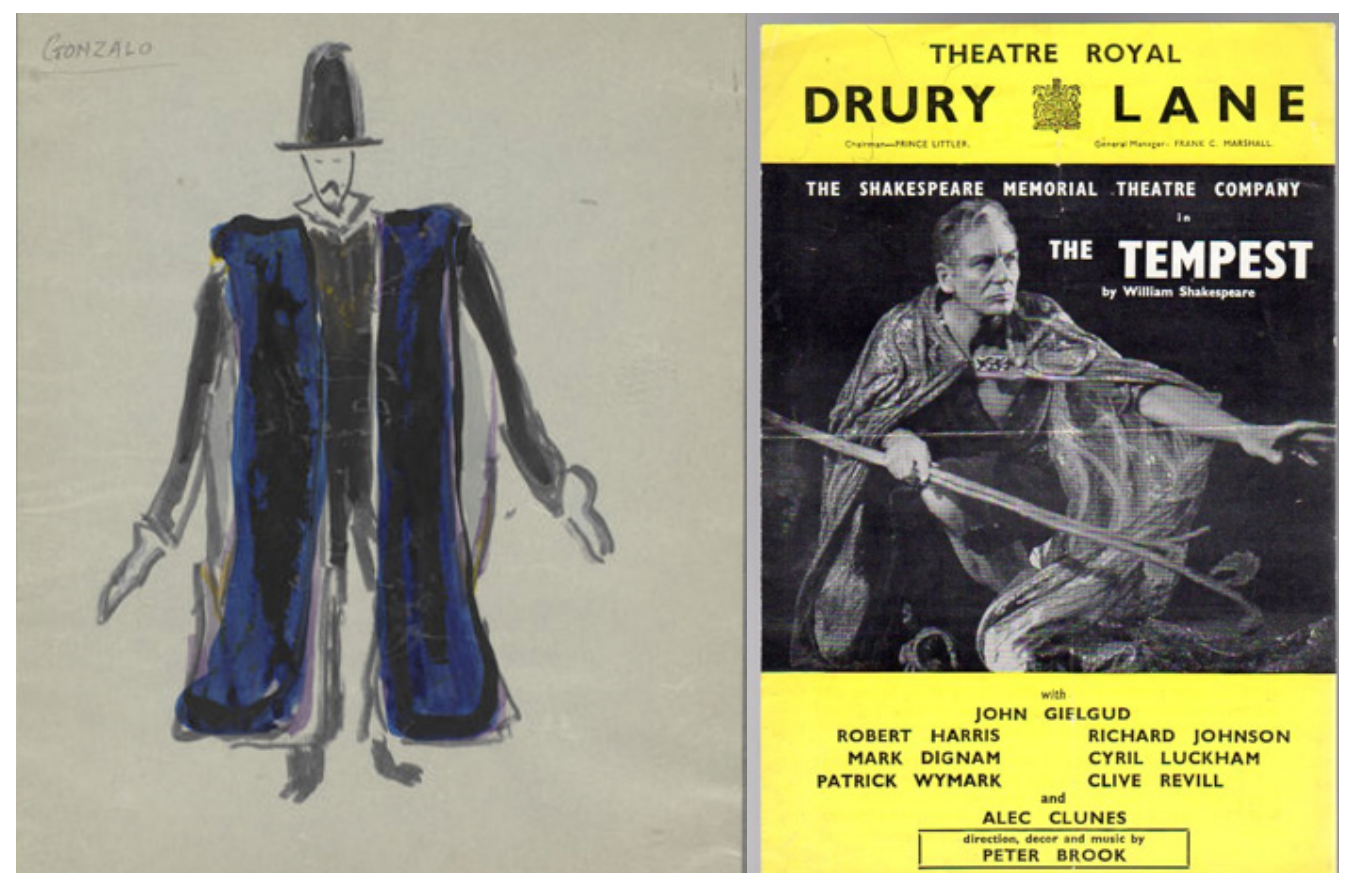

Fonte:Acervo V\&A Museum. 
Em 1968 teve um novo contato com o texto, em caráter experimental, ao escolher algumas cenas como matéria-prima para o desenvolvimento das improvisações e pesquisas. Esta experiência ocorreu durante a realização da primeira oficina com atores internacionais, em Paris, o que levou alguns anos mais tarde à formação do Centro Internacional de Pesquisa Teatral com artistas oriundos de diferentes culturas, conforme relatado anteriormente.

Devido aos acontecimentos de Maio de 1968, decidiram regressar à Inglaterra, devido ao contexto conturbado do país. Quando chegaram, Brook e alguns membros do grupo de Paris decidiram se reunir na Round House de Londres para dar continuidade ao trabalho iniciado, colocando em cena um novo espetáculo experimental com fragmentos de A Tempestade. Para surpresa dos espectadores, nessa montagem não havia cadeiras no espaço teatral, em seu lugar foram colocados tamboretes de madeira espalhados pelo espaço (figura 47) de modo que, tanto os atores como os espectadores, poderiam mudar rapidamente de posição quando o andaime móvel se dirigisse em sua direção. Brook (2000) comenta, em Fios do Tempo que essa montagem causou muito espanto nos espectadores.

Figura 47 - A Tempestade (1968) direção de Peter Brook no Round House em Londres.

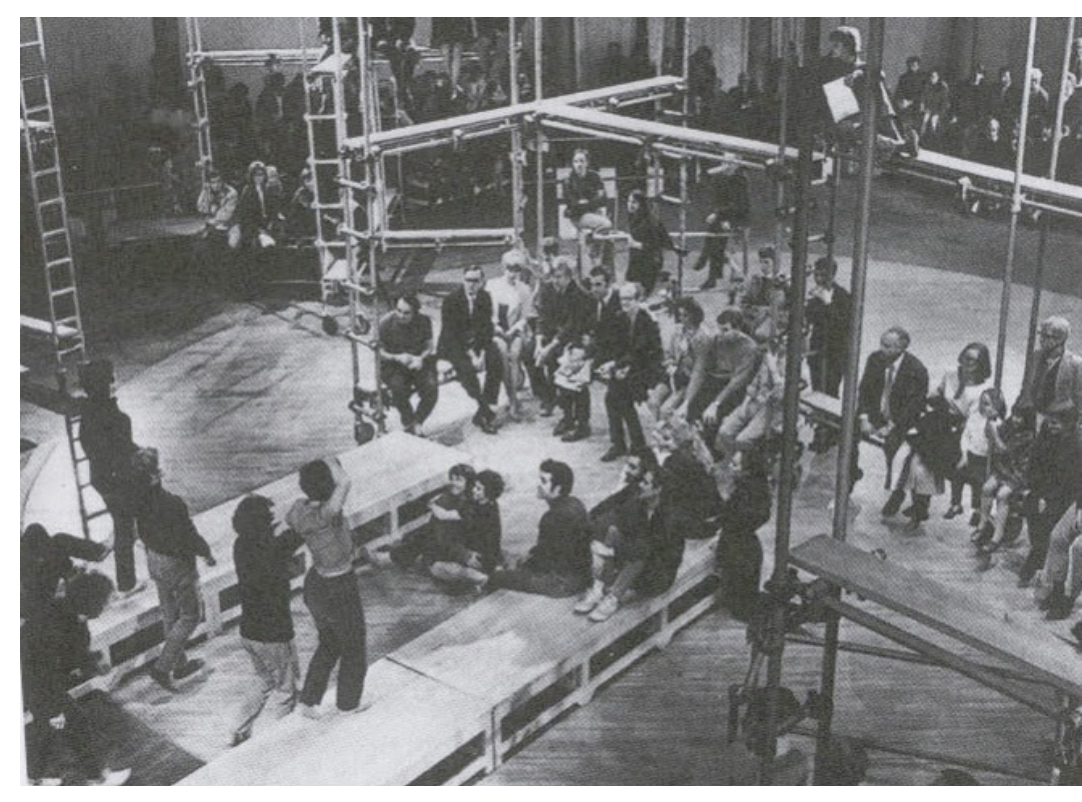

Fonte:Tood; Lecat (2003, p. 36). 
De volta ao processo de seleção do texto a ser trabalhado após a grande produção do poema hindu Mahabharata, Brook (2005) conta que, curiosamente, não havia pensado no texto de Shakespeare para trabalhar com seu grupo de atores até que um amigo inglês sugeriu A Tempestade como solução para aquele momento em que se encontravam. Logo as vantagens da opção ficaram evidentes para o diretor, pois, de acordo com suas convicções, uma peça de Shakespeare somente poderia ser montada quando se tivesse a certeza de contar com os atores apropriados. Brook percebeu que um dos atores africanos do grupo, Sotigui Kouyaté, poderia trazer uma nova leitura, diferente e mais autêntica, para o protagonista Próspero. Assim como os demais membros do grupo também poderiam incrementar o jogo teatral com o frescor de suas próprias culturas e tradições.

Desse modo pediu que Carrière preparasse a tradução em francês e logo iniciou as discussões dos cenários e figurinos com Obolensky, artista que já estava integrada ao grupo desde $O$ Jardim das Cerejeiras. Essa montagem representou um novo momento na produção de Brook, pois se tratava de um espetáculo curto, simples e sem adornos, ou seja, totalmente diferente da produção de O Jardim das Cerejeiras e do espetáculo que o antecedeu, Mahabharata. Todavia, por mais diferentes que estas obras fossem, o estilo da produção de Brook estava presente em todos os trabalhos: uma estética simples e clara, que contava com um elenco com atores de diferentes nacionalidades. $O$ diretor não se contentou somente em encenar um espetáculo; ele procurou uma qualidade de interpretação que permitisse revelar o que chama de "o mundo invisível sob o texto" (BROOK apud CROYDEN, 2003, p. 232); um mundo que não é facilmente compreensível e reproduzível em termos teatrais.

\subsection{1 - O processo de criação de A Tempestade (1990)}

De acordo com Brook (2005), em um primeiro momento, os ensaios foram planejados para durarem três meses e meio. Mas logo em seguida percebeu que seriam necessários mais dois meses para concluir o processo e estrear a peça. Buscava-se tocar o invisível e a direção estava interessada em fazê-lo por meio de uma imagem. Procurava fugir da convenção de se fazer uma leitura moderna do texto pois, de acordo com suas convicções, desse modo os espectadores não conseguiriam penetrar profundamente nas questões do texto. Ao mesmo tempo pretendia libertar-se do clichê de utilizar as imagens remotas do passado, de deuses e reis, comumente utilizadas nas produções dessa comédia shakespeariana.

Nos primeiros dez dias de preparação todos os atores 
trouxeram seus textos, mas sequer o tocaram. Primeiro fizeram exercícios para os corpos e, posteriormente, para as vozes. Os exercícios corporais tinham o objetivo de desenvolver reações rápidas, para transformá-los em uma equipe sensível e vibrante. Porém, além dos corpos, os pensamentos e sentimentos deveriam ser entrosados com exercícios de voz e improvisações, tanto cômicas como dramáticas, para fazer com que realmente se apropriassem do universo proposto no texto. Após alguns dias se exercitando, foram introduzidas no exercício teatral as palavras, seguidas de sequências de palavras e, finalmente, frases inteiras, de modo a fazer com que os atores adquirissem uma proximidade com a linguagem do autor.

Para Brook (199I apud CROYDEN, 2003, p. 237) A Tempestade (figura 48) não é uma peça sobre o colonialismo, ou que Caliban represente a natureza perversa do homem - duas leituras bastante comuns ao texto naquela época. Segundo ele nada é pesado ou sério no texto, pois Shakespeare escreveu o espetáculo como uma fábula encantadora, leve, fácil e rápida. Ao escutá-la cuidadosamente, pode-se observar uma grande profundidade a ser percebida através de uma linguagem fácil, aplicada aos jogos teatrais.

Figura 48 - Cartaz de A Tempestade (1990) direção de Peter Brook.

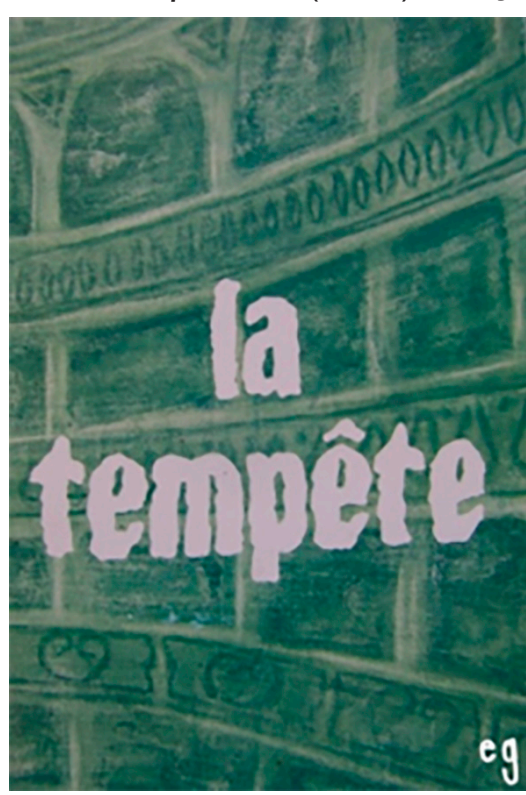

Fonte: Brook (1990). 
Durante muitos anos, seguindo a tradição inglesa, esse espetáculo tem sido concebido com muitas trocas de cenários, trajes bonitos e máscaras. Contudo, essa montagem de Brook, não pretendia ser colocada sobre o ponto de vista histórico. Não buscou nenhum realismo, pois para ele, a ilha, de fato, não existe. Qualquer tentativa de localizá-la nestes moldes seria infrutífera. De acordo com a entrevista realizada por Croyden (2003), Brook ao renegar estas convenções, e conceber o espetáculo de forma muito leve, fez com que o jogo cênico ganhasse em qualidade. Desse modo sua abordagem explorou bastante a imaginação do público, mas com absoluta seriedade.

Era a quarta experiência de Brook com o texto e, nesta ocasião, escolheu uma das formas aparentemente mais simples para a representação: o espaço vazio. $O$ palco deveria ser desprovido de elementos, exceto por uma grande rocha e uma caixa de areia retangular. $O$ navio condenado era simulado pelos atores, vestidos com trajes escuros, que manipulavam uma variedade de varas de bambu e eram acompanhados de gritos e música tocada por dois músicos sentados ao lado do palco. O primeiro choque para o público foi Ariel, pois, de acordo com Croyden (2003), esperavam a jovem garota frágil com um tutu delicado ou calças brancas e se depararam com o africano Bakary Sangaré, que carregava um navio de brinquedo com velas vermelhas na cabeça para dizer a Próspero - também encenado por um alto ator africano, Sotigui Kouyaté -, que ele havia criado a tempestade.

Logo Caliban aparece saindo de uma caixa de papel. Outro choque: tratava-se de David Bennent, ator de baixa estatura com grandes olhos azuis e vestido com um saco de tecido bruto. Em cena, embora ele cuspisse, gritasse, mordesse e subisse em cordas, parecia mais um selvagem patético, quase desamparado, do que propriamente um monstro. Miranda segue a linha proposta por Shakespeare em seu texto é encenada por uma jovem atriz indiana Shantala Malhar-Shivalingappa, de catorze anos de idade, que foi treinada como dançarina pela mãe desde cedo. O mesmo ocorre com a personagem Ferdinando, interpretado por Ken Higelin, que aparenta ter somente um pouco mais de idade.

Nessa versão tudo era criado a partir da sugestão e da fantasia: borboletas eram balançadas em varas conduzidas por fadas; nas roupas dos dois marinheiros bêbados - Bruce Myers e Alain Maratrat - foram colocadas asas. Os sons da floresta eram evocados pela música tocada em cena. $O$ vestido de noiva de Miranda era constituído por um véu feito por gazes, as fadas brincavam com areia, aros e cordas que serviam para irritar a tripulação perdida. As personagens saltavam e brincavam na caixa de areia colocada no centro do espaço de representação e, também, subiam pelas laterais do teatro. 
As cenas cômicas eram parte da ação dramática e não somente quadros pontuais. Brook agregou um frescor e uma qualidade juvenil a esta encenação que induziu, nos espectadores, uma nova forma de se relacionar com o texto. Seu objetivo não foi abordar as questões psicológicas mais sombrias, nem trajes luxuosos e os efeitos teatrais espetaculares, geralmente associados com as demais montagens. Não era somente uma síntese do minimalismo, mas tinha a clara intenção de assemelhar-se ao universo da imaginação infantil.

De acordo com Croyden (2003, p. 233),

As fadas dominam a realidade com jogos divertidos, charadas inteligentes e magia sobrenatural para criar uma ilha de fantasia, um habitat natural ou, se preferir uma paisagem de ilusão. A ação, com suas cenas cômicas habilmente atuadas com inúmeros fragmentos inventivos - típicos do humor de Brook, era tão repentino, jovial e extravagante que, as duas horas e meia ininterruptas passaram como um sonho repentino e estimulante.

\subsection{2 - A encenação de A Tempestade (1990)}

Horowitz (2004) em seu livro Próspero's “True Preservers”, relata como foi realizada a encenação do espetáculo $A$ Tempestade montada por Brook, em 1990. Por meio de seus depoimentos é possível compreender algumas questões referentes à configuração do espaço cênico e à utilização dos adereços produzidos para a cena, o que certamente contribui para a compreensão do desenvolvimento da pesquisa espacial nas produções do diretor.

Uma das questões que foi bastante latente nessa produção foi o uso de poucos elementos, como, por exemplo, somente com dois músicos foi possível representar uma orquestra, ou mesmo a partir de três folhas de palmeira indicar uma floresta, ou ainda, como uma pequena bandeja de frutas indicou um verdadeiro banquete. Essa solução cênica foi possível, sobretudo, pela seleção de itens simbólicos e carregados de significados para o público, além da destreza dos atores e músicos envolvidos no processo que, sob a orientação da direção, conseguiram enaltecer estes poucos elementos, fazendo com que adquirissem outras proporções. Outra questão premente nessa produção é, sem dúvida, o aprofundamento do intercâmbio cultural explícito em algumas soluções cênicas e nos trajes dos atores.

A peça tem início quando os músicos se instalam sentados sobre tapetes persas na lateral do palco. O espírito Ariel entra em cena com um modelo de navio a velas pintado de vermelho e preso na cabeça; traz consigo um casco de troncos de madeira e atravessa a areia em silêncio, bastante concentrado. Em um ponto específico do palco de areia, perto do local em que Próspero estava 
sentado, tira o capacete com o navio e o deposita sobre a areia (figura 49). Trata-se do primeiro evento de magia do espetáculo, quando o capacete se transforma no navio encalhado dos tripulantes de Nápoles. Próspero estuda as circunstâncias e, gradualmente, invoca uma tempestade.
Alguns críticos sugerem que a cena de abertura, tal qual descrita acima, lembrava um ritual não-ocidental. Enquanto Próspero concentra sua energia na pequena embarcação encalhada, Ariel se move atrás dele e manipula um comprido e grosso "pau de chuva" (instrumento musical), decorado com motivos africanos.

Figura 49 - A Tempestade (1990) cena de Sotigui Kouyaté e Bakary Sangaré como Ariel e Próspero na ilha de areia.

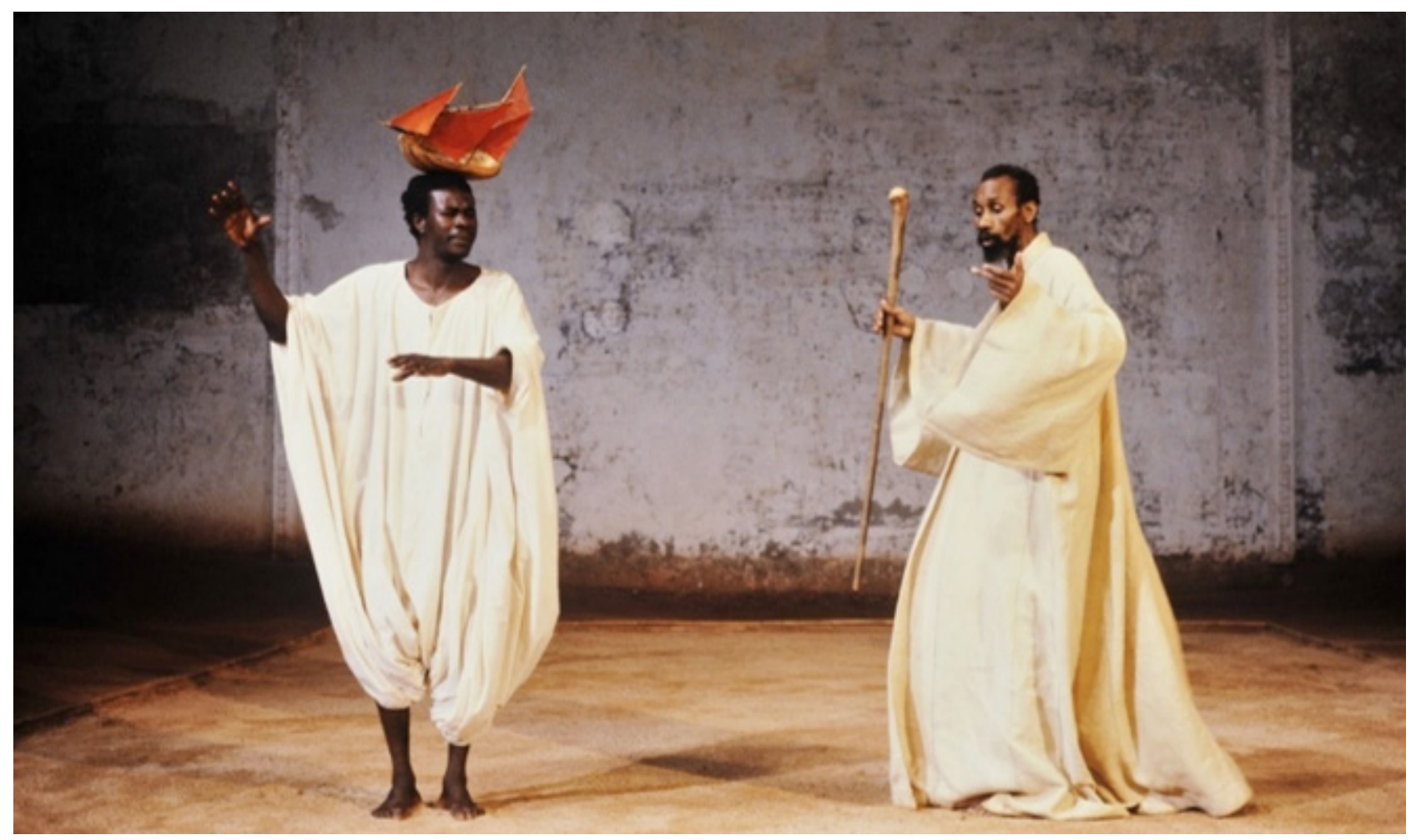

Fonte: Cande (1990). 
O movimento ondulado e lento do instrumento faz com que Ariel anuncie a iminente tempestade.

Ao mesmo tempo um grupo de atores, tripulantes da embarcação, adentram ao espaço cênico e começam a realizar movimentos que simbolizam os efeitos da magia sobre o navio (figura 50). Esta ação, nas circunstâncias em que ocorriam concomitantemente no palco, cria efeitos cinematográficos na encenação, de acordo com alguns espectadores da época. Na sequência os tripulantes prestes a naufragar, munidos de longas varas de bambu, realizam movimentos que simulam a tentativa de manter o controle da embarcação. Os bambus, por sua vez, indicam em alguns momentos o mastro, em outros o convés com seus trilhos, ou ainda o nível de água subindo à medida que a embarcação se despedaça.

Figura 50 - Cena de ATempestade (1990) em que temos à frente os tripulantes do navio e ao fundo Ariel e Próspero.

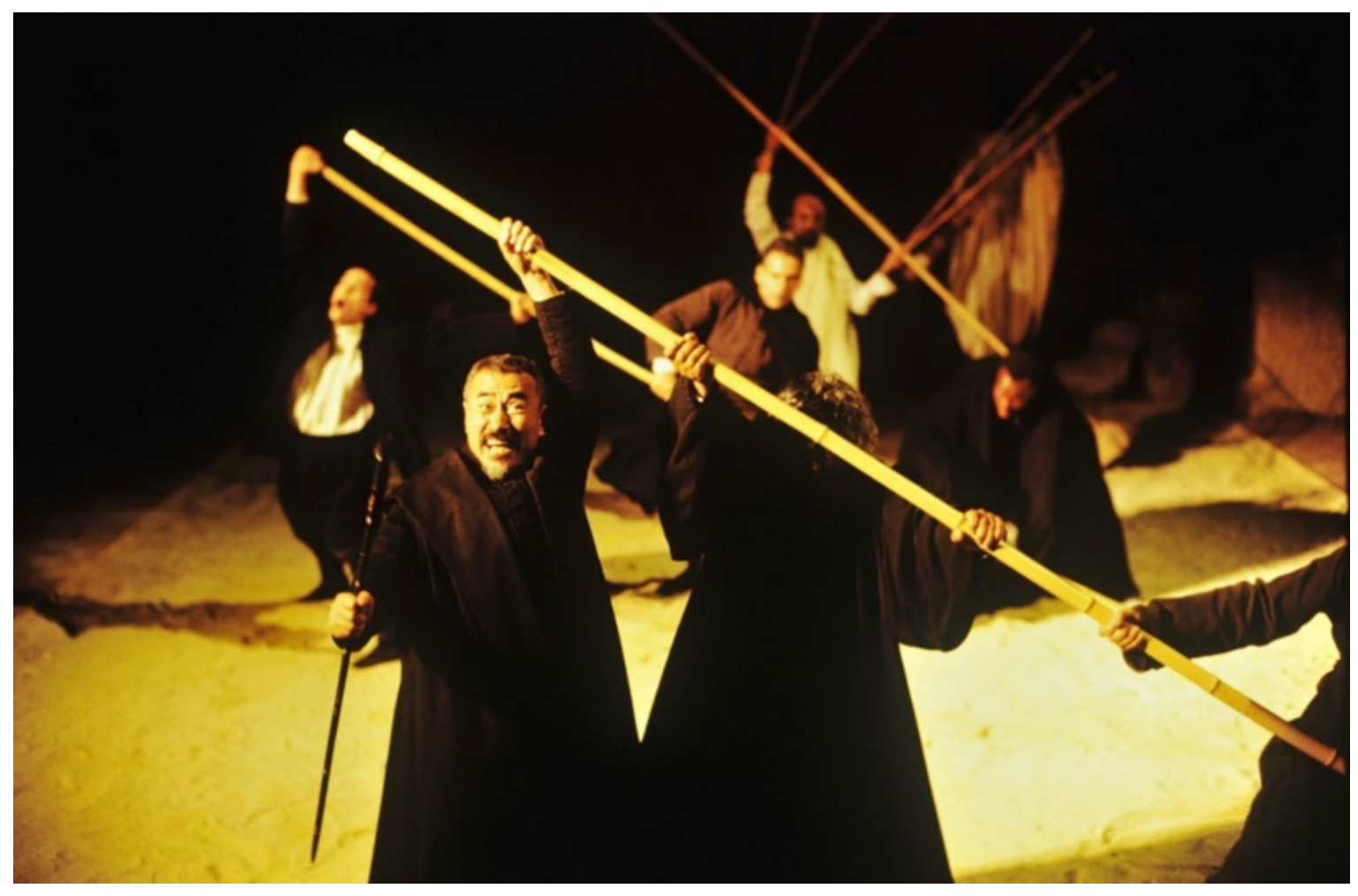

Fonte: Cande (1990) 
Ariel e dois de seus ajudantes invadem o navio e, com seus gestos, intensificam a tempestade. Os cortesãos de Milão e Nápoles aparecem vestidos com calças pretas, camisas brancas e longas capas também pretas. Tentam lutar contra a tempestade utilizando seus bambus. Dentre eles destaca-se Yoshi Oida, que interpreta Gonzalo, e transforma seu bambu, com movimentos corporais, na superfície do mar e, com suas habilidades físicas, representa um homem se afogando. Devido à destreza do ator o público teve uma apreensão bastante profunda da cena da tempestade.

Acerca do que foi mencionado, Horowitz (2004) revela que a inglesa Poh Sim Plowright, diretora de teatro Nô na Grã-Bretanha, descreveu que a cena da tempestade foi encenada como uma farsa para crianças. Porém, as circunstâncias apresentadas não permitiam a distinção entre o real e o imaginário. Desse modo a plateia podia, mesmo que de forma estilizada, compartilhar do horror vivenciado por pessoas em situações de acidentes como esta. Na sequência das cenas, à medida que a tempestade cessa e os tripulantes saem do navio, Próspero permanece com sua filha, Miranda, no mesmo ambiente, evidenciando seu domínio sobre a ilha.

Os náufragos estavam de mãos dadas no mesmo momento em que Próspero olhava para além das dimensões de sua ilha, compreendendo as circunstâncias que os conduziram até ali. Ele pede a sua filha para que compartilhe suas memórias e, durante o questionamento, segura um amuleto acima da cabeça dela. Enquanto Miranda revivia sua infância de olhos fechados, seu pai fazia o mesmo, refletindo sobre suas lembranças da perda do ducado e a traição de Sebastião e Alonso. A maneira como a transmissão de pensamentos acontecia, imprimia a solenidade de um ritual sagrado africano.

Próspero continua com sua exposição ao descrever a gentileza do "nobre napolitano, Gonzalo" enquanto Yoshi Oida caminha como se estivesse muito cansado no fundo da cena até sentar-se sobre a rocha, solitária no palco. Os três nobres, Alonso, Sebastião e Antônio, separados de Ferdinando, atravessam o palco, aparentemente desesperados e cansados. Ao saírem de cena, Gonzalo lentamente se levanta da rocha e os segue para o centro da área de encenação.

Em seguida Próspero insiste para que Miranda não faça mais perguntas e vá dormir, assim ele e Ariel possam discutir sobre os resultados da tempestade. Então a posicionam no chão, virada para frente, seu corpo endurece e seu rosto se torna inexpressivo. Seu pai segura um amuleto e, de forma amorosa e protetora aplica um feitiço, para que ela não se envolva na sua vingança. Próspero foi representado por Brook simultaneamente como um mágico poderoso e um pai protetor. Logo após Miranda se muda para a rocha e 


\section{adormece.}

Ariel aproxima-se de Próspero e, sentados na areia, relata orgulhosamente usando o tronco de madeira e a sua cabeça para demonstrar onde ele lançou seus raios. Recriou os sons que seu feitiço provocou na destruição. A demonstração agrada a Próspero e, em seguida ao questionar o espirito sobre a realização de suas ordens, Ariel escala uma das paredes laterais do proscênio, por meio dos anéis metálicos que estavam fixados para que pudesse escalar até as alturas, de modo a observar novamente seu feito com o navio, mostrando ao seu mentor a localização precisa da embarcação.

A produção havia decidido se concentrar em contar os temas expostos por Shakespeare em A Tempestade, fugindo de contextualizar a peça no período pós-colonial, como costumavam a maioria das demais produções ocidentais. Caliban, pessoa escravizada selvagem e deformado, foi encenado por um ator bastante pequeno que se parecia com um anão branco. De acordo com Horowitz (2004), nesta montagem de Brook, Caliban foi a personagem mais contemporânea. $O$ objetivo declarado foi fazer com que tivesse a ferocidade, o perigo e a rebeldia de um adolescente da década de 1990. Alguns críticos ainda estabeleceram um paralelo entre as suas atitudes com as dos hooligans - jovens ingleses e europeus, turbulentos, desempregados, que ficavam bêbados em jogos de futebol e tinham atitudes agressivas.

Brook ainda atualizou o destino de Caliban ao igualar sua situação com a de Próspero e aproximá-los de moradores sem-teto contemporâneos. Esta opção é evidenciada quando decidiram por converter a célula do escravo em uma caixa de papelão, equivalente aos abrigos dos atuais moradores de rua (figura 5I). Entretanto, ao passo que o restante das personagens lendárias da ilha se assemelhava à figuras de uma lenda folclórica africana atemporal, Caliban, com um corte de cabelo pós-moderno, se aproximava desse jovem irritadiço que é reflexo dos abusos materialistas vividos pela Europa na década de 1980. 
Figura 5 I - Caliban saindo de sua célula, a caixa de papelão que o assemelha aos sem-teto e o corte de cabelo pósmoderno com expressão irritadiça.

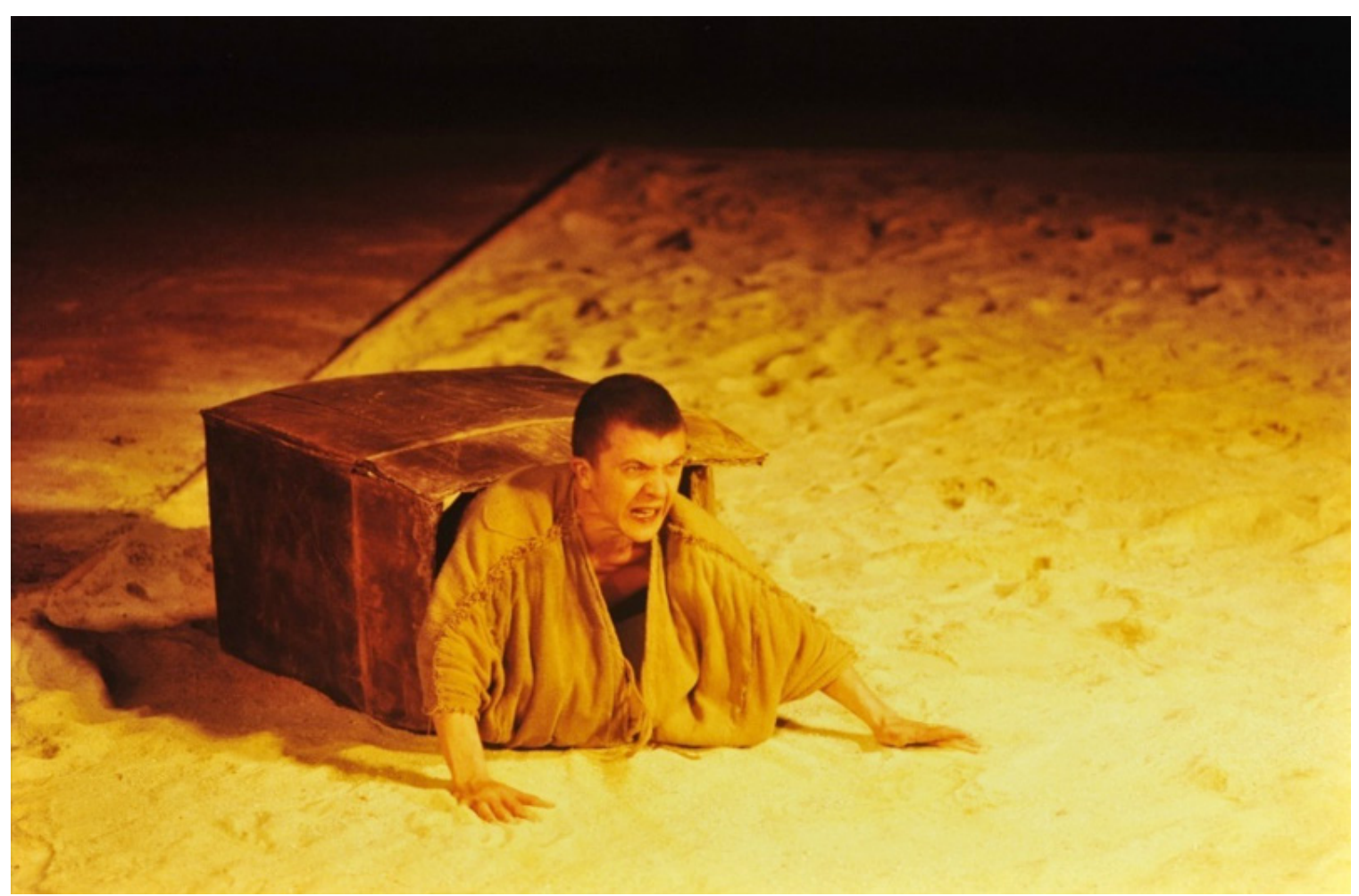

Fonte: Cande (1990)

Em sua primeira entrada Caliban carrega uma velha caixa de papelão, cujo signo aproxima-se das habitações urbanas dos sem-teto contemporâneos. Ao adentrar em cena se senta sobre o abrigo para jantar, um milho bastante fino que cospe na areia, mostrando sua aversão a este alimento inconsistente. Logo após Próspero o ameaça, e o escravo corre para o lado oposto ao de
Ariel, escalando a outra lateral do proscênio.

Tanto Caliban como Ariel permanecem sentados nas bordas superiores das paredes do teatro, observando a ação que se sucede. O escravo veste um reles manto/cobertor de serapilheira marrom e se esforça para romper a espessa corda, amarrada ao seu corpo 
como símbolo de seu aprisionamento. Seus músculos, particularmente os do pescoço, estão tensos devido à pressão e seu rosto não disfarça sua ira, está bastante avermelhado, parecendo estar à beira de uma explosão. Em contraposição Ariel permanece sentado com bastante serenidade vestindo uma túnica branca que não transmite qualquer tipo de tensão.

Quando Próspero força Caliban a se curvar à sua vontade, usa castigo físico e o ameaça psicologicamente com mais um abuso. Em um desses momentos a bengala serve para imobilizar o escravo no chão. Nestas circunstâncias o antigo Duque de Milão se assemelha bastante com um pai tirano e severo que repreende uma criança indefesa. Caliban, no entanto, tem as mãos sob o nariz, que o assemelha a uma criança tentando desaparecer atrás de suas mãos durante um jogo de "esconde"; ele se move em diversas direções como se estivesse procurando a bruxa, Sycorax, para que ela lhe concedesse proteção divina contra $o$ ataque de Próspero.

A seguir os exilados na ilha de Próspero chegam ao seu primeiro destino. Antônio e Sebastião tramam o assassinato de Alonso e Gonzalo. O último deles permanece sentado no chão, cercado por castelos de areia, criados pelos emissários espirituais de Ariel e Próspero. É importante ressaltar a simbologia atribuída à imagem do castelo de areia que se tornou uma imagem chave para o personagem. Ao mesmo tempo em que Gonzalo medita sobre uma colônia utópica que imaginava governar, um dos espíritos emissário de Ariel está atrás dele.

O espírito segura um bastão fino com uma grande folha no topo que se transforma em asas mágicas de um pássaro, representando as criaturas estranhas e maravilhosas que habitam não só a ilha, mas o mágico mundo imaginário que Gonzalo sonha comandar. No terceiro ato, primeira cena, depois de Ferdinando suportar as brincadeiras dos espíritos de Ariel que repetidamente roubam as toras de lenha que organiza, ele e Miranda trocam seus votos de amor.

Uma floresta é criada pelos espíritos que seguram suas varas de bambu na vertical; eles evitam olhar diretamente para o público para não se intrometerem na cena de amor e intimidade dos jovens. Este é um importante momento de quebra no ritmo e intensidade do espetáculo; pois mudou-se de uma situação mais rápida e cômica para um momento de maior imobilidade e romance entre os dois. Durante esse encontro, Próspero está posicionado em cima da cena, atrás dos jovens amantes, e observa como se fosse espectador de sua própria invenção, aguardando o resultado da situação. 
Figura 52 - Simulação de floresta realizada pelos espíritos em cena de A Tempestade (1990).

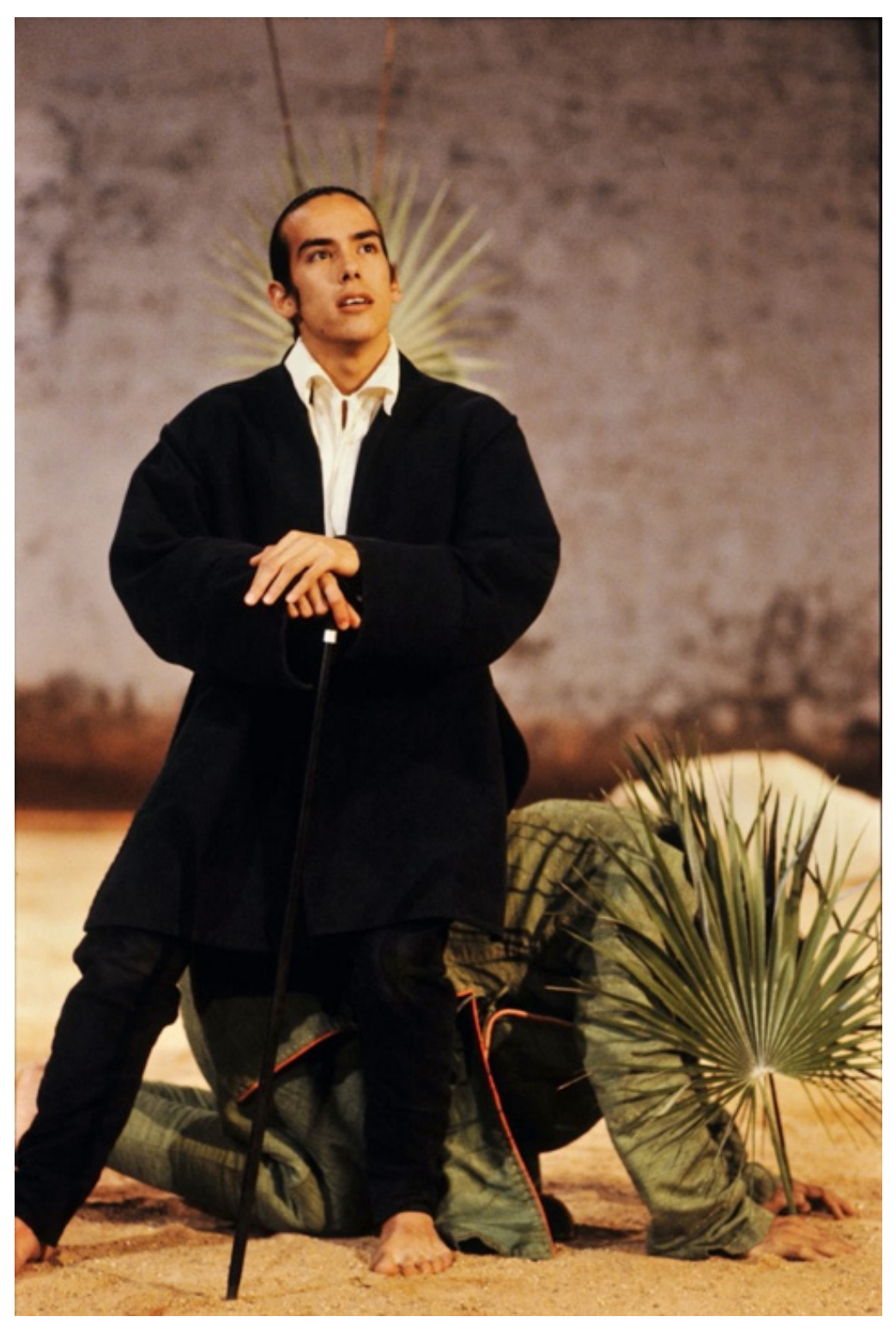

Fonte: Cande (1990). 
Em contraste a este interlúdio romântico está a primeira entrada dos clowns: Estéfano e Trinculo, que improvisam com sons inventados (gromelô ${ }^{15}$ ) e com alguns elementos da comédia de entretenimento. Quando se reúnem, reconhecendo-se como cavalheiros napolitanos, entram em uma corrente de falso italiano, que se concluiu com uma irreverente aria de ópera. As cenas em que estão presentes são repletas de homenagens às origens da comedia dell'arte. Por exemplo, quando Estéfano (Alain Maratrat), interpreta o rei para a ordenação de Caliban a cavaleiro, ordena que Trinculo (Bruce Myers) fique mais longe; Bruce então caminha em direção à parede dos fundos do palco e Maratrat grita "Mais longe!", e quando Myers tenta atravessar a parede.

A produção utiliza algumas referências da commedia dell'arte, que não se limita somente às cenas que envolvem as personagens cômicas do espetáculo. Por exemplo, na cena em que Ferdinando prova sua obediência à Próspero e sua dedicação à Miranda, transportando e empilhando troncos de madeira, dois dos espíritos de Ariel se tornam arlequins invisíveis e roubam os troncos ajustados, reconduzindo-os novamente ao

${ }^{15}$ Gromelô é uma palavra inventada pelos cômicos dell'arte e italianizada pelos venezianos, que pronunciavam gramlotto. Apesar de não possuir um significado intrínseco, sua mistura de sons sugere um sentido para o discurso. Trata-se, portanto, de um jogo onomatopéico, articulado com arbitrariedade, mas capaz de transmitir, com o acréscimo de gestos, ritmos e sonoridades particulares, um discurso completo. monte original para que fossem empilhados de novo.

Os papéis dos assistentes espirituais de Ariel servem, não só como seus emissários, mas como artesãos e, também, interferem diretamente no contexto cênico. São visíveis ao público, porém invisíveis às personagens. Em alguns momentos do espetáculo seguram objetos como pedaços de plantas tropicais e borboletas em frente de suas vítimas, particularmente de Gonzalo e Ferdinando, de modo a realizar alguma magia. Tornamse os cantores durante as cenas Trinculo-EstéfanoCaliban e depois do banquete com as máscaras. Nessas cenas, além de cantarem, são responsáveis por manejar os adereços cênicos que permanecem em cena, tais como: os jarros de vinho, as comidas, as argolas, fitas, as plantas e os trajes de cena que não são mais utilizados.

Uma das cenas em que fica evidente a intervenção dos espíritos invocados por Ariel é o momento em que Ferdinando, enfurecido pelas exigências e insultos de Próspero, prepara-se para atacá-lo ao desembainhar sua espada. Nessa situação um dos assistentes espirituais torna-se, novamente, parte do contexto cênico, como se não estivesse presente enquanto personagem. Ariel coloca-se no palco se encostando no mesmo bambu ornamentado usado como varinha mágica durante a cena da tempestade.

Ferdinando realiza uma movimentação parecida com uma mistura entre posições de karatê com passos de 
dança, enquanto segurava sua espada negra em ambas as mãos. Sua tentativa de ataque à Próspero é frustrada por Ariel que sorria com a mesma facilidade com que ele imobiliza o filho do rei de Nápoles, que tenta saltar sobre uma misteriosa vegetação criada por um dos espíritos, agachado e vestido de verde segurando uma quantidade expressiva de folhas paralisantes em sua frente. Na sequência duas varas finas se estendem de ambos os lados e em cada uma delas havia uma borboleta, uma vermelha e outra branca. Logo surge magicamente uma floresta inteira com os movimentos das folhas das palmeiras e os bambus manipulados pelos atores.

O banquete, assim como todas as cenas mais espetaculares da produção, foi encenado com simplicidade e poucos efeitos pirotécnicos. Os onipresentes assessores de Ariel trazem os cortesãos para repousarem em uma mesa baixa, semelhante às mesas japonesas. Então recebem uma variedade de uvas e vinhos dos espíritos que são visíveis ao público, mas não podem ser vistos por Antônio, Gonzalo, Alonso e Sebastião. Por meio de mímica, expressam os prazeres de comer e beber; assustados sem compreender o que estava acontecendo, os náufragos se encolhem e recuam da mesa. Ao observarem que o banquete era consumido por mágica, deixam seus próprios pratos intocados. Os espíritos, "não vistos", rapidamente atingem a mesa e seus conteúdos e sua invisibilidade serve como "dispositivo pitoresco colocado no palco".

A cena dos mascarados, embora tenha sido bastante reduzida nessa produção, dava continuidade ao intercâmbio cultural e à simplicidade teatral almejada por Brook. Sobre a utilização de máscaras, o diretor reutiliza as questões místicas, as quais experimentou e obteve sucesso quando experimentou situação semelhante no espetáculo Mahabharata. Tanto na produção do mito hindu quanto em A Tempestade, acredita que havia encontrado uma solução no uso de máscaras exóticas.

Torna-se bastante evidente que seria ridículo um ator ordinário pretender ser um deus. Pode-se verificar esse fato até mesmo em produções de $A$ Tempestade, em que muitas garotas tentam ser deusas; A Tempestade costuma ser um desastre. Assim, é preciso recorrer para alguma coisa que possa vir em auxílio, e a primeira coisa que surge nesse sentido é uma máscara que contenha poderes e evoque forças superiores às que o próprio ator possa invocar. Jamais as vi sendo utilizadas dessa maneira no teatro ocidental, e acho que é algo muito perigoso de se abordar caso não se tenha adquirido muita prática e compreensão. No Oriente e na África, essa espécie de máscara é mais empregada em rituais, mas em certo sentido, é usada com o mesmo propósito, que é o de trazer para fora elementos abstratos que de outra 
maneira são apenas chamados de forças, e fazer com que eles assumam aspectos de carne e osso (BROOK, 1994, p. 301-302)

A cena das máscaras inicia-se com os assistentes espirituais cobrindo a areia com um pano dourado ondulado. $\mathrm{Na}$ sequência Miranda entra no quadrado de areia, um dos assistentes espirituais que carregava duas varas de bambu, nas quais um xale de renda branca era sustentado. Em seguida o xale é colocado sobre os ombros da filha de Próspero e os bastões são transformados em uma moldura móvel. O casamento realizado com as máscaras, em uma situação de metalinguagem teatral, em que os personagens observam uma cena de casamento realizada no palco. Ferdinando juntou-se a Miranda no palco à esquerda e Próspero estava à direita, observando toda encenação: tanto a cena do casamento, quanto a reação dos jovens amantes.

Uma fumaça de incenso encobre o teatro e deusas aparecem, atuando e dançando em círculo. Seu traje é mais um exemplo de intercâmbio cultural, pois elas usavam máscaras coreanas pintadas de branco e roupões dourados com toques vermelhos diáfanos, além de bubus africanos (robes de mangas largas) que estavam cortados para se parecerem com sari indiano. Todavia, as deusas conjuradas pela magia de Próspero para entreter Ferdinando e Miranda, são rapidamente descartadas, o que faz com que a cena das máscaras se conclua rapidamente. Quase imediatamente após a chegada das ninfas dançantes, Próspero se lembrou "da conspiração suja”, e a cena foi abortada abruptamente.

A última cena entre Próspero e Ariel é realizada com uma dignidade silenciosa que sublinhava o forte vínculo entre o mestre e seu assistente. Antes de libertar seu súdito, Próspero o mantem firmemente em seus braços. Ambos olham para frente e a renúncia à magia por parte do legítimo Duque de Milão deixa o liberto Ariel com um grande senso de falta de propósito. Esse sentimento é dramatizado por uma pausa no choro e um olhar para trás ao mesmo tempo em que o espírito se afasta lentamente.

Próspero permaneceu em silêncio, triste e sozinho, no centro de seu círculo mágico de seixos na areia. Após o discurso final de Próspero, um dos assistentes espirituais arrumam discretamente a areia, reconfigurando a área de representação de volta à estaca zero, ou seja, o ponto de partida do espetáculo. Trata-se de uma evidência proposital da direção sobre a natureza cíclica desta produção e, também, da própria vida. As luzes do palco enfim se acendem e revelam o retângulo de areia raspada com a única pedra, tal qual se iniciou a peça. A magia de A Tempestade estava pronta para ser reproduzida novamente e, consequentemente, a distinção entre ilusão e realidade, início e fim, ficava 


\section{obscurecida.}

Em última análise $A$ Tempestade incorpora as técnicas de narração que Brook estava praticando em outros projetos, porém afasta-se da meta-teatralidade em que os elementos dominantes são o teatro de ilusão e a arte. Para esta encenação o diretor argumenta que "o tema essencial não é a ilusão do teatro, não é o palco, mas a vida" (BROOK, apud HOROWITZ, 2004, p. 163). Neste intuito Brook transforma a renúncia de Próspero em magia e a ilusão em sua negação ao virtuosismo teatral e à pirotecnia em cena.

Todas as propostas eram provenientes dos atores que foram convocados por Brook para preencher o espaço, os silêncios e a própria fábula com clareza e leveza. Portanto, deu-se grande ênfase aos signos e símbolos durante a performance - as representações e os sinais criados pela luz, pela areia, pela música e pelo manejo do bambu realizado pelos atores. A magia que provinha dessa produção veio do uso econômico, porém altamente eficaz, da manipulação da imaginação no exercício teatral. De forma minimalista uma tigela com algumas poucas frutas se tornava um banquete, três folhas exóticas eram uma floresta e quatro varas de bambu, uma caverna ou um navio em perigo. $O$ som de areia passando por um tubo na cabeça de Ariel era uma tempestade, e o "espaço vazio" de Brook transformavase uma ilha mágica e misteriosa.

\subsection{3 - Processo de criação do espaço cênico e dos trajes de cena de A Tempestade.}

Durante a pesquisa sobre o processo de criação desta versão de $A$ Tempestade, ficou evidente que a cenografia e a definição do espaço de representação no espetáculo estavam entre as grandes preocupações de Brook e seus colaboradores. Pode-se observar que, nesta peça houve um intenso processo de simplificação na concepção espacial e no trabalho de criação do diretor. Ressaltase que o espaço cênico e a cenografia foram aspectos determinantes para a concepção do espetáculo. Encontrou-se muito pouco material sobre a criação dos trajes de cena. Porém, fica evidente que, na concepção dos trajes, essa condição ainda não tinha atingido todas as possibilidades minimalistas investigadas pelo diretor.

Brook (2005) diz que ao reler a peça sentiu que as experiências espetaculares que havia produzido em seu primeiro contato com o texto não deveriam ser a solução para esta nova montagem. Intelectualmente intuiu que a peça não deveria ter bases realistas e que a ilha era simplesmente uma imagem simbólica - ou seja, não deveria ser representada de forma literal. Ao terminar a sua leitura, fez no verso do texto o esboço de um jardim zen, "como o de Quioto, onde uma ilha é sugerida por uma rocha e a água por pedrinhas secas" (BROOK, 2005, p. 90).

Porém, ao fazer uma reunião com a cenógrafa e 
figurinista Obolensky, só apontaram desvantagens para essa solução inicial e descartaram a primeira intuição do diretor. Durante os ensaios no Théâtre des Bouffes du Nord, a designer preparou uma série de elementos cênicos que permitiam aos atores a experimentação de algumas possibilidades, tais como: cordas penduradas no urdimento, escadas, pranchas, cubos de madeira, caixas de embalagem, tapetes, montes de terra de diversas cores, pás e enxadas. Estes objetos serviam de base para que os atores pudessem experimentar em suas improvisações e decidissem o que deveria permanecer na encenação.

De acordo com Brook (2005, p. 94) foram realizadas várias experimentações "no instante em que as ideias surgiam, tudo era muito estimulante, mas nada convincente sob um olhar mais frio no dia seguinte, e acabava sendo invariavelmente descartado sem dó nem piedade". Àquela altura nada parecia estar adequado aos propósitos do grupo. As imagens produzidas apresentavam algum inconveniente, ou eram muito convencionais, ou intelectuais demais. Assim todos os acessórios propostos acabaram descartados. Contudo Brook ressalta que neste processo de experimentação, nada se perdia completamente. Algum vestígio aparecia inesperadamente em outra cena mais adiante. Como exemplo revela que se não:
[...] tivéssemos gastado tanto tempo experimentando com o barquinho na cena inicial, Ariel nunca teria tido a ideia de interpretar sua primeira cena com Próspero equilibrando um barco de vela vermelha sobre a cabeça; aí sim o acessório era genuinamente útil um elemento necessário para dar maior vivacidade às suas ações (BROOK, 2005, p.95).

O diretor ressalta que Shakespeare, ao escrever A Tempestade como uma fábula, queria evitar momentos de maior dramaticidade, mantendo um tom de leveza à obra toda, assim como um contador de histórias do Oriente faz em sua atividade. De modo a atingir tal objetivo, foram necessárias diversas improvisações e invenções até descobrirem os modos diferentes de evocar a ilha com recursos bastante simples. Durante as primeiras semanas de ensaio, tanto Brook quanto Obolensky estavam convencidos de que precisavam de um espaço vazio para permitir fluir a imaginação da plateia. Haviam rejeitado diversos acessórios, tais como pisos de madeira ou tapetes. Até que, em um fim de semana, a cenógrafa levou ao ensaio uma quantidade significativa de terra vermelha.

Naquele momento $\circ$ barco era realizado com a movimentação de algumas varetas de bambu na horizontal que, posteriormente, foram postas na vertical para evocar com clareza a floresta. Os espíritos precisavam somente de alguns elementos, tais como: 
folhas de palmeira, punhados de grama ou ramos de arbustos, para fazer truques com a imaginação. Em um dado momento ficam apavorados ao perceber que haviam sido conduzidos à armadilha de adaptar a peça ao cenário, tentando justificar as cenas com uma sucessão de imagens realistas.

A reversão dessa condição foi possível devido a um processo que havia se tornado prática regular em seus métodos de ensaio. Depois de um período de aproximadamente dois terços do programado para os ensaios quando os atores já haviam se apropriado do texto entendido a história e quando o espetáculo já começava a tomar forma em termos de marcações, objetos de cena, cenário e trajes de cena, o grupo encenava o espetáculo para crianças em uma escola. lam ao local de representação desprovidos de todos os elementos, e deveriam improvisar uma versão da peça com os materiais e as possibilidades existentes na sala. O objetivo era fazer com que os atores se tornassem exímios contadores de histórias encontrando meios imediatos de captar a imaginação de seus observadores.

Nessa experiência com A Tempestade, ao apresentarem a cena sobre o tapete num espaço mínimo, conforme relata Brook (2005, p. 99) "a peça ganhou vida na mesma hora." Logo após, chegaram à conclusão, aparentemente óbvia, que esta peça deveria ser despojada de qualquer proposta decorativa que limitasse a imaginação.
Para surpresa dos atores, quando voltaram ao teatro, havia sido sugerida uma redução na área de interpretação, o que, além de conferir uma maior concentração da ação, libertou-os de certo naturalismo e fez com que os objetos manipulados voltassem a fazer sentido na encenação. Começaram experimentando com a colocação de um tapete persa no centro dessa área. Todavia identificaram que o excesso de desenhos tolhia a imaginação da plateia, uma vez que o tapete era repleto de elementos figurativos. A seguir decidiram usar um tapete sem desenhos, mas prontamente percebem que esse signo remeteria a elementos que eram irrelevantes à encenação.

Obolensky, então, emoldurou a área de representação coberta de terra vermelha com varas de bambu. Removeu o tapete e cobriu essa área com areia branca, mas deixou o bambu permanecer conformando um retângulo perfeito. Deste modo continuavam com a proposta do tapete, mas de areia. Ao verem os atores ensaiando nesse espaço, perceberam que o problema central do espaço de representação estava resolvido. Contudo a cenógrafa optou por colocar duas rochas no retângulo de areia, que posteriormente foi reduzida a uma, para conferir pontos de referência ao espetáculo.

Assim, como se pode verificar nas figuras 53 e 54, determinou-se a ilha de Próspero como um depósito de areia clara com formato retangular, com tamanho 
aproximadoao de uma quadra de tênis (24 por I I metros), delineados por alguns bastões de bambu que conferiam características tanto simbólicas quanto teatrais ao longo da produção. Conforme indica Horowitz (2004, p. I 54), a ilha no início das apresentações era representada

Figura 53 - ATempestade (1990) estrutura do espaço de representação e delimitação da área de encenação em adaptação do espetáculo para o Teatro Ginza.

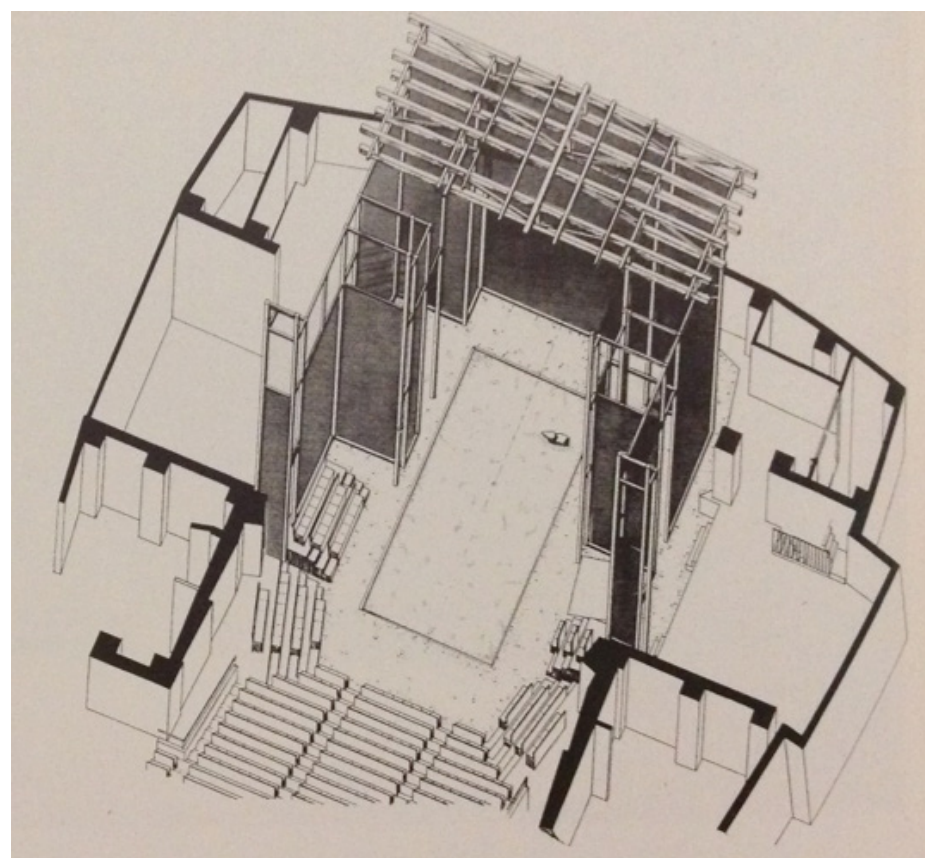

Fonte:Todd; Lecat (2003, p. 80). por espirais concêntricas com uma única pedra bruta colocada em um canto do cenário "sugerindo algo da ilha de Próspero e ,também, do casco quebrado de um navio encalhado".

Figura 54 - A Tempestade (1990) foto da adaptação do espaço cênico para o espetáculo no Festival de Avignon.

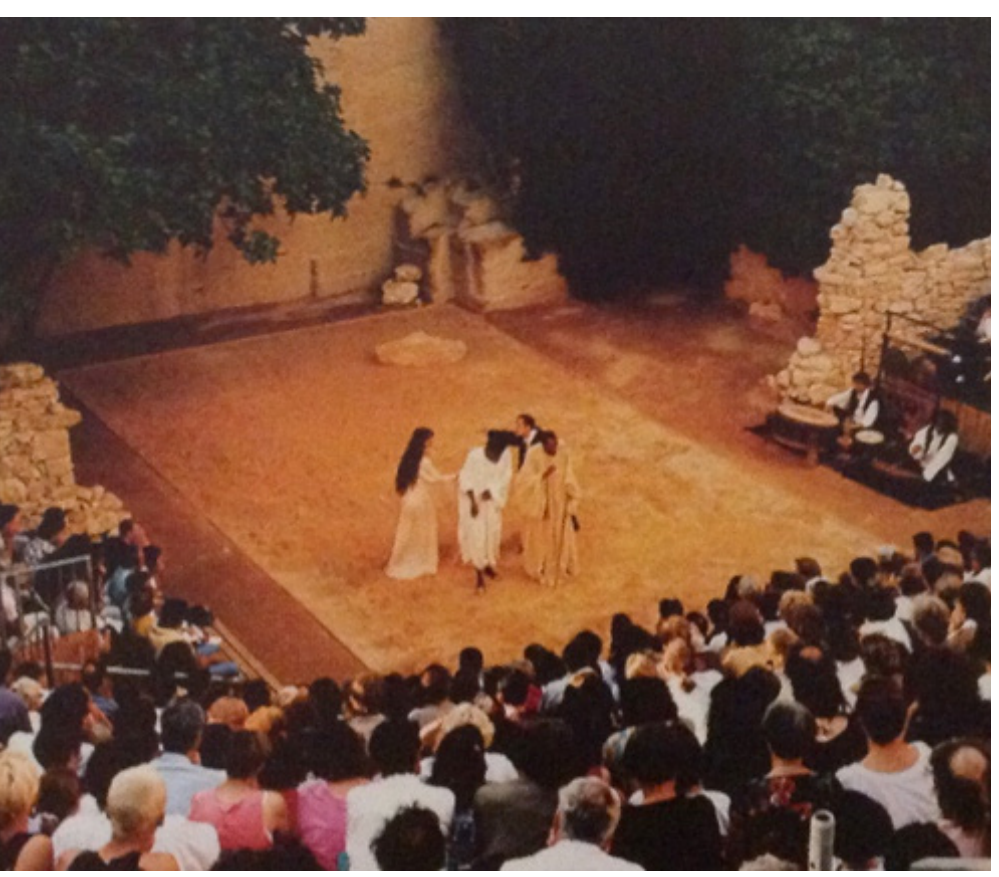


Para a alegria de Brook, alguns críticos compararam essa solução com um playing field, outros com playground - termos que correspondem exatamente ao que pretendiam desde o início: "um lugar para o jogo cênico ou, em outras palavras, um lugar em que o teatro não pretendesse ser nada mais que teatro" (BROOK, 2005, p. 10I). Também houve quem comparou a proposta cenográfica do espaço de representação com um jardim zen, o que remetia diretamente à ideia inicial do diretor. Carlson (apud HOROWITZ, 2004, p. I53) comentou sobre o conjunto da areia no piso do palco, com os instrumentistas africanos e asiáticos que faziam as intervenções musicais na encenação à vista do público, sentados em tapetes persas, os trajes de cena bastante leves e fluidos, que conferia extrema simplicidade visual à encenação.

Georges Banu (apud HOROWITZ, 2004, p. 153), por sua vez, comentou sobre o impacto conferido pelo design do palco que seria o resultado do Jardim Zen japonês na concepção do espetáculo, a partir da escolha final de Obolensky. Banu descreve:

[...] o universo limitado de pedra e as pedras dentro dos templos zen (particularmente aqueles dos jardins zen em Quioto) como uma metáfora ideal para um mundo ordenado permeado tanto pela realidade quanto pela espiritualidade, onde $o$ visitante não pode ignorar a onipresença de qualquer um deles (apud HOROWITZ,
Banu (1992 apud HOROWITZ, 2004) argumenta que Brook e Obolensky acabaram conferindo para a imagem da ilha certa ambiguidade ao enfatizar a posição de Próspero tanto como um juiz e fiscal da má administração, como seu papel de mago espiritual desse espaço estéril e ordenado. Além dessas possibilidades apresentadas acima, o espaço cenográfico proposto para a ilha também pode ser compreendido como um parque infantil alegórico, no qual toda a vida poderia ser sentida durante as três horas de peça.

Para completar a intervenção no espaço teatral, as paredes do Théâtre des Bouffes du Nord foram transformadas para esta produção. $O$ fundo do palco foi pintado de branco - e continuou a revelar as texturas da antiga parede deteriorada através dos tempos e as paredes das laterais foram pintadas de verde. Estas duas cores eram extremamente importantes para essa produção, conforme veremos adiante. $O$ contraste de cores foi um elemento bastante utilizado na composição deste espetáculo. Ora era evidente nos tons da terra e areia do cenário (respectivamente vermelho e branco), ora estava presente na seleção de cores utilizadas nos trajes dos personagens (figura 55). 
Figura 55 - Figurino de A Tempestade (1990) concebido por Chloé Obolensky. Túnicas brancas simbolizam os habitantes da ilha em contraste direto com os náufragos

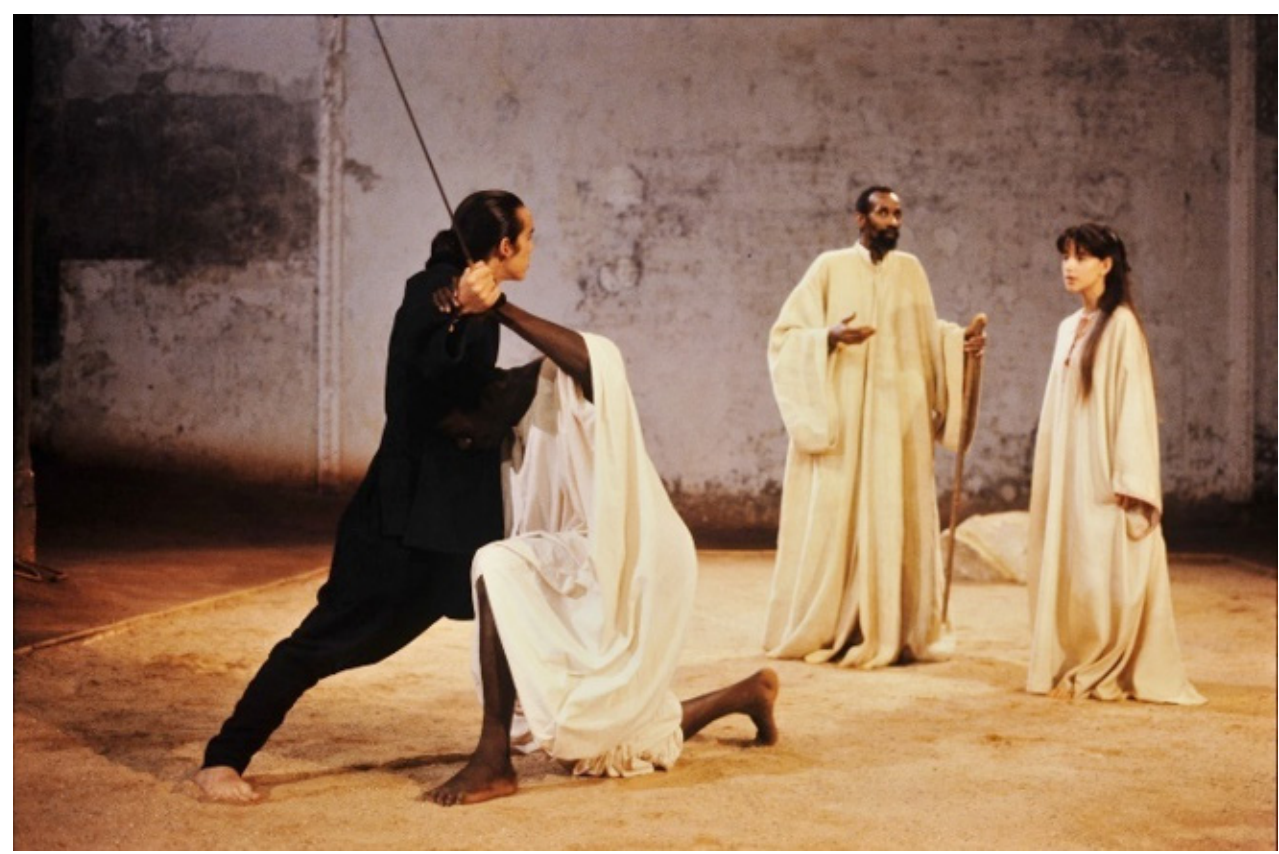

Fonte: Cande (1990).

Enquanto os habitantes da ilha estavam vestidos com túnicas bastante leves, flutuantes e brancas ou de cor clara - Ariel, por exemplo, não veste propriamente o branco, mas uma túnica de cor crua -; os náufragos usavam casacos sóbrios, retos e escuros, muitos deles com desenhos claramente inspirados em desenhos da época Elisabetana (figura 56). Certamente a seleção das cores para estas personagens não foi aleatória.

De acordo com as teorias de Kandinsky (1996), a cor branca seria um sinal de resistência. É uma cor cheia de possibilidades que pode significar pureza, alegria e esperança, mas para as culturas orientais está ligada ao símbolo da transformação e do luto. Enquanto o preto, seria sinal de ausência de resistência, ou seja, representa a extinção de algo e o nascimento de um mundo novo, tal como acontece no decorrer do texto com o processo de transformação das personagens dos náufragos. 
Figura 56 - À esquerda retrato de homem do século XVI da época Elisabetana provável inspiração de formas para os trajes dos náufragos de A Tempestade (1990)

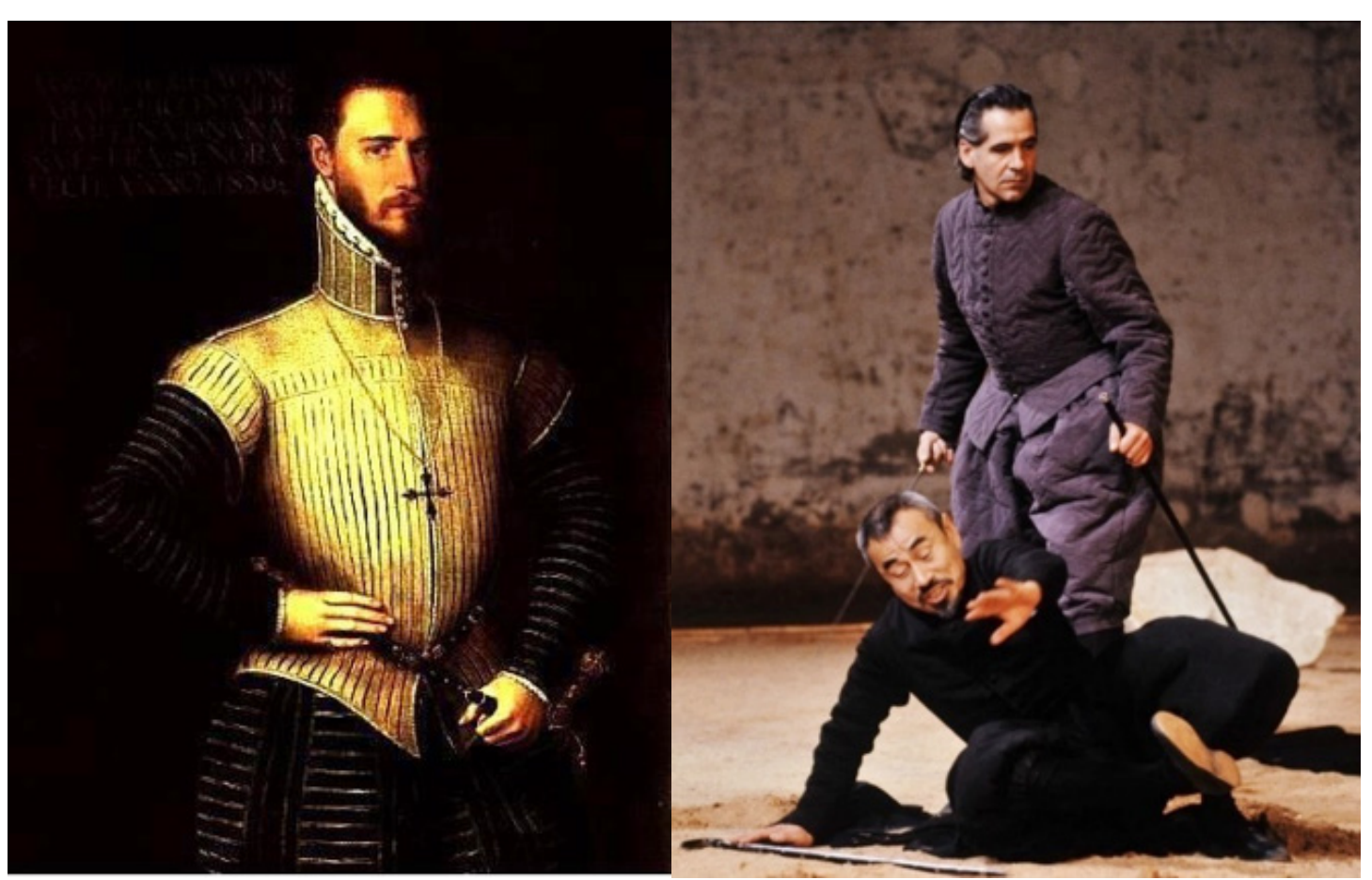

Fonte: Cande (1990)

Outra cor utilizada nos trajes das personagens é o verde, atribuído aos personagens trapaceiros, Trinculo e Estéfano, os marinheiros bêbados, que forneciam um alívio cômico ao espetáculo. Para Kandinsky (1996) o verde é a cor mais calma de todas. Representa a passividade saudável repleta de satisfação, momento de vitalidade e exuberância. Nas culturas orientais ela é símbolo de fertilidade, sorte e riqueza, ou seja, atributos que Brook também gostaria de transmitir como mensagem de seu espetáculo. Este foi o modo com que Brook traduziu a mensagem do texto, fazendo com que seus espectadores, através da imaginação, pudessem se reportar ao que o grupo pretendia e transmitir a mensagem idealizada por Shakespeare. 
Figura 57 - Figurino de A Tempestade (1990), cena de Ariel com os marinheiros bêbados - utilização das cores contrastantes - preto, brancos e verdes

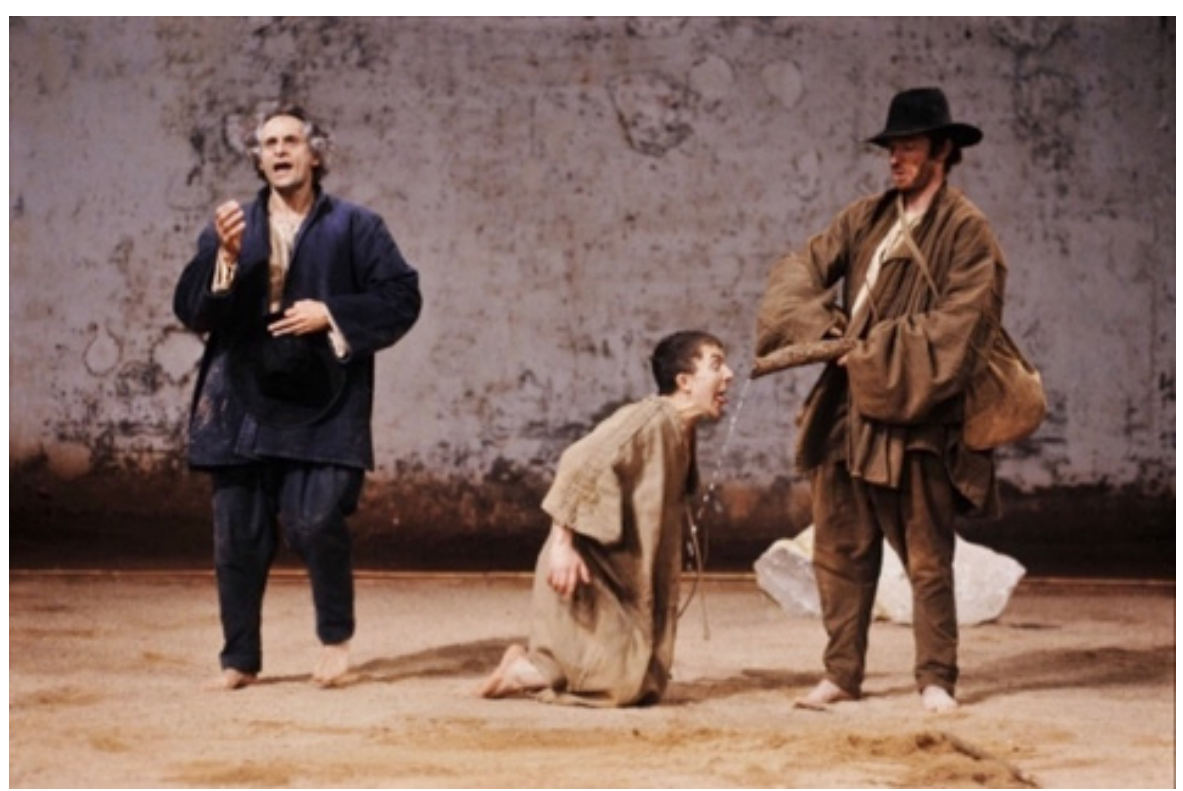

Fonte: Cande (1990).

A partir do que foi exposto, fica evidente que esta montagem de A Tempestade, apesar de não ser tão divulgada e difundida dentre os espetáculos de Brook, teve um papel bastante relevante em relação ao processo de síntese artística do diretor. Vale ressaltar, sobremaneira, que nesse contexto a criação cenográfica foi fundamental no processo de criação visual do espetáculo, contribuindo inclusive como elemento de significação. Ao simplificar os elementos cênicos e ao utilizar o tapete de areia como espaço de representação teatral, todas as escolhas de material e os desenhos dos trajes de cena foram, ainda mais, evidenciados.

Pode-se observar que nos trajes deste espetáculo, assim como em algumas outras peças do diretor, existe uma intenção de não imprimir referência temporal. E neste caso, fica ainda mais evidente a dualidade entre esta intenção, pois de um lado as personagens do mundo alegórico de Shakespeare recebem vestimentas simples, sem referência temporal e com cores neutras; em contraste com as personagens humanas que conservam algumas características histórico-culturais com cores marcantes e que conduzem o espectador a um período 
específico. Contudo, essas dualidades nos trajes acabam se tornando referências para que o espectador perceba a diferença entre os universos expostos pelo autor, tornando-se então mais um elemento de significação relacionado à parte visual do espetáculo.

Desse modo é possível observar que, ao compreender o processo de evolução da produção teatral de Brook, há um passo significativo rumo à produção simbólica e ao que o próprio Brook define como Teatro Sagrado. E essa transformação adquire proporções distintas em relação à concepção do espaço cênico propriamente dito que se aproxima definitivamente de uma estrutura simbólica, ao passo que os trajes de cena ainda carregam de certa forma algumas características voltadas a um realismo simbólico, uma vez que é possível identificar o período histórico aplicado aos trajes não alegóricos das personagens.

\section{3 - AS RELAÇÕES ESPACIAIS DE O JARDIM DAS CEREJEIRAS (198I) E A TEMPESTADE (1990)}

Existem diferenças nítidas nas soluções espaciais e produções dos cenários dos espetáculos $O$ Jardim das Cerejeiras e $A$ Tempestade. $O$ primeiro é o espetáculo que marca a entrada de Obolensky no CICT, fato este que contribuiu de forma determinante na criação dos elementos visuais e espaciais dos espetáculos do grupo. Percebe-se que, com sua chegada, houve um aprofundamento em alguns elementos visuais dos espetáculos de Brook que já estavam presentes nas concepções do trabalho do grupo, porém adquiriram novas proporções. Uma pesquisa mais profunda acerca de elementos históricos e a inclusão de algumas referências nos trajes de cena que foram determinantes para contribuir no envolvimento dos espectadores em cena, como se pode notar em ambos espetáculos analisados nesse capítulo.

Além dessa importante parceria, que possibilitou um aprofundamento nas investigações de Brook acerca do espaço de representação e dos elementos visuais colocados em cena, nestas montagens deve-se ressaltar o protagonismo que o espaço de representação adquiriu. No caso de $O$ Jardim das Cerejeiras, todo o Théâtre des Bouffes du Nord foi incorporado ao espetáculo, ou seja, se tornou parte ativa da cena. Também foi explorada a sua condição degradada que contribuiu demasiadamente para o imaginário da propriedade degradada que seria leiloada. Ao ser revestido com tapetes floridos que chegavam aos pés dos espectadores, ficava nítida a necessidade de sua inclusão na peça.

É interessante destacar o uso do tapete como forma de linguagem para determinar o universo cênico. Em paralelo, no espetáculo A Tempestade o espaço de representação também foi determinado pelo uso do 
tapete, que veio para o trabalho de Brook desde suas excursões investigativas na África. Neste caso o tapete, um elemento fundamental da representação, era um campo de areia demarcado por bambus. Quer ele seja interpretado como uma área de recreação, quer ele seja um jardim oriental, esse tapete de areia permitiu que fosse marcado o registro da encenação devido a seleção de um material maleável. Ao final do espetáculo, quando os rastros na areia eram intencionalmente apagados para que uma nova memória fosse realizada, ficava clara a intencionalidade de fazer com que o cenário também transmitisse uma mensagem ao público.

A partir do que foi observado, deve-se atentar para a permanência do espaço vazio concebido por Brook em ambas encenações. Evidencia-se a escolha por colocar poucos elementos cenográficos. Percebe-se a presença de poucos adereços e quase nenhuma construção colocada em cena. Para que fossem incorporados ao espetáculo, precisavam ser significativos ou determinantes para a representação, como é o caso dos biombos em $O$ Jardim das Cerejeiras, que eram fundamentais para alterar a configuração espacial dos cômodos da casa em cada cena, ou da poltrona e da estante que interferiam na cena final com 0 abandono de Firs.

Em A Tempestade os elementos fundamentais foram; os bambus que os atores manipulavam em cena e os transformavam em outros elementos a partir da imaginação da plateia; a rocha, que, conforme explica Brook (apud CROYDEN, 2003) para Obolensky foi importante para que se tivesse a noção de profundidade do espaço e a caixa de papelão, que conferia uma qualidade à personagem de Caliban, aproximando-o aos moradores de rua. Essa opção de colocar em cena poucos elementos reforça um dos principais pontos de investigação sobre o Teatro Sagrado definido por Brook. Deve-se tornar visíveis os elementos invisíveis colocados no texto, por meio do trabalho e destreza do ator ao estimular, a imaginação dos espectadores.

Deve-se atentar, também, para a questão do desenvolvimento espiritual do diretor no período em que foram desenvolvidos estes dois espetáculos. No caso de $O$ Jardim das Cerejeiras, é importante ressaltar que fazia somente dois anos que Brook havia estreado o filme Encontro com Homens Notáveis (1979) responsável por retratar a história de seu mentor espiritual. Portanto, ainda que as filmagens tivessem acontecido antes da realização de A Conferência dos Pássaros (1979), seu trabalho de aprimoramento continuou a ser realizado e, provavelmente, reverberou também nessa composição.

$\mathrm{Na}$ montagem de A Tempestade é significativo salientar que foi exatamente neste mesmo ano, no mês de maio, que sua mentora Madame de Salzmann faleceu. 
espetáculo estreou em setembro e, como Brook (2000) relata foram necessários mais de cinco meses de ensaio para a montagem; desse modo sabe-se que houve uma infeliz coincidência de situações, pois esse falecimento ocorreu exatamente durante os ensaios do espetáculo.

Certamente essa circunstância provocou alguma interferência significativa no caminho de aprimoramento espiritual do diretor. Um aspecto da montagem que sobressai, nesse sentido, é a possibilidade de recomeço do espetáculo ao final do processo, - que indica a probabilidade de continuidade da representação, simbolizando a possibilidade de se reescrever (reapresentar) a situação proposta, como se houvesse uma continuidade, ainda que não visível aos espectadores. 


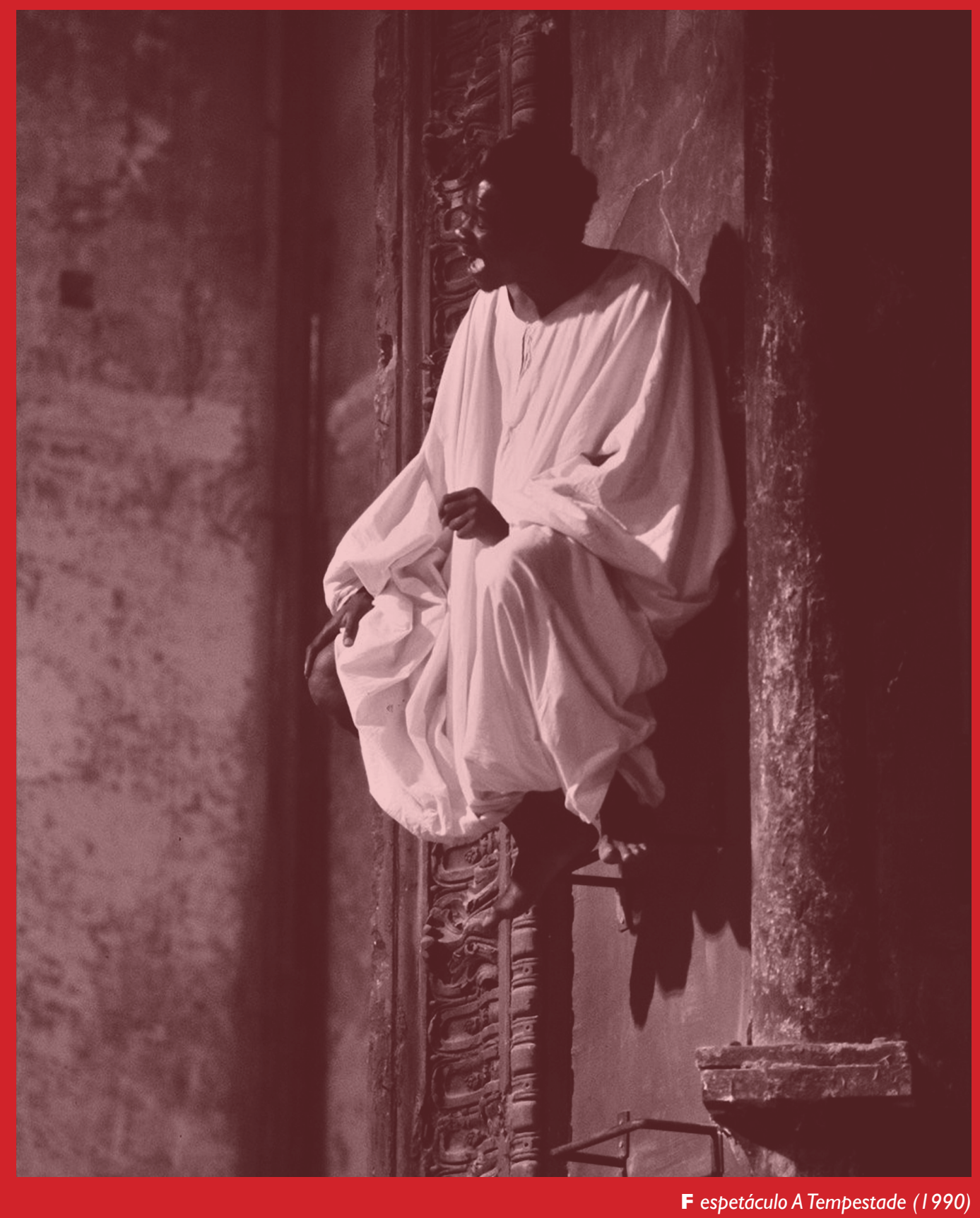





\section{TEATRO SAGRADO CONSOLIDADO: A TRAGÉDIA DE HAMLET (2000)}

Parte-se, finalmente para a análise dos momentos de consolidação dos conceitos de TeatroSagrado apontados por Brook. Identifica-se, portanto, a consolidação da trajetória de simplificação da concepção espacial e cenográfica no espetáculo A Tragédia de Hamlet (2000).

Sobre o espetáculo, A Tragédia de Hamlet é importante comentar que, durante $\circ$ mestrado realizado pelo autor desta tese, este espetáculo foi analisado. Desse modo, para obter mais informações sobre a análise detalhada do texto de Shakespeare, bem como do processo de idealização do espetáculo, recomenda-se a leitura do capítulo referente ao espetáculo no trabalho: Do espaço vazio ao círculo aberto (ORTIZ, 20I3). Esta nova pesquisa irá, portanto, se atentar somente aos elementos significativos da montagem do espetáculo relativos à concepção dos trajes de cena e elaboração dos cenários.

\section{I UMA PROPOSTA SIMBÓLICA PARA A} TRAGÉDIA DE HAMLET (2000).

Essa foi a quarta experiência de Brook com este texto de Shakespeare. Em 1954, realizou a primeira turnê inglesa, logo no pós-guerra. Dez anos depois, retomou com uma nova versão sobre o texto no teatro LAMDA, 
à frente da Royal Shakespeare Company, e contou com a colaboração de Charles Morrowits. Sua terceira aproximação com esta obra foi a pesquisa relacionada com os apontamentos dos principais teóricos de artes cênicas do século $X X$, em que se passava por trechos de Hamlet no espetáculo Qui est là (1995).

É relevante destacar que a ideia de montar esta peça surgiu durante os ensaios de Qui est là, que reunia uma série de fragmentos de Hamlet. Brook (2000 apud COROYDEN, 2003, p. 255) afirma que durante o processo de ensaio pensava que seria interessante realizar a peça de uma forma concentrada. Seguiu, naquele momento, uma tendência que se tornou recorrente em seu trabalho: guiar-se pela intuição.

Assim, praticamente na virada do milênio, montou um espetáculo com o objetivo de atingir temas profundos, que refletissem sobre a totalidade humana, em um momento em que as barreiras e as distâncias globais pareciam estar diluídas, abrangendo um público mais diversificado e heterogêneo. Desse modo, em 21 de novembro de 2000, estreiou, no Théâtre des Bouffes du Nord, A Tragédia de Hamlet falada, totalmente, no idioma original do autor.

Para Brook (2004, p.29) este texto é inesgotável, ilimitado. Fiel ao estilo de seleção multirracial de atores, em todos os processos do CICT, A Tragédia de Hamlet foi protagonizada pelo ator britânico, negro,
Adrian Lester, que iniciou as apresentações com uma caracterização impressionante e em eloquente entrega ao texto de Shakespeare.

Brook (apud BANU, 200I) acreditava que a presença de um grupo multicultural sempre produzia um significado diferente de um grupo culturalmente homogêneo, uma vez que a presença de atores pertencentes a várias culturas sempre trazia à tona um aspecto mítico ao trabalho. Lester, neste caso, tinha um alcance extraordinário: cantava e se movia lindamente, dançava e era uma pessoa adorável, além de ter uma sensibilidade bastante aguçada para as palavras e seus significados.

Em entrevista a Banu (200I), o encenador inglês afirmou que Hamlet era uma peça bastante complexa. $\mathrm{E}$, devido a essa complexidade, era fundamental que se partisse para uma grande simplicidade na elaboração do espetáculo, pois de outra forma seria facilmente possível de se perderem na montagem. Essa primeira aproximação era essencial para que se estabelecesse uma leitura aprofundada do texto e não partissem para outas leituras sobre a peça. $O$ foco dessa aproximação era constituir um contato mais aproximado das questões centrais do texto shakespeariano.

Brook (apud BANU, 200I) ressalta que, antes dessa montagem, estavam também diretamente ligados aos problemas ocorridos na África do Sul, especialmente - Apartheid. Haviam acabado de se defrontar com a 
experiência de montar um espetáculo de autoria de um escritor sul-africano com a montagem de Le Costume de Can Themba. Depois de realizarem o espetáculo sulafricano, Brook pensou que não poderiam negligenciar as obras do passado e decidiu retomar seu contato com a pesquisa de Hamlet.

De tal modo, ao encenar Hamlet, pensaram em realizar um projeto mais global que poderiam complementar com as discussões contemporâneas do espetáculo Le Costume, que deixava o presente para se encontrar com a realidade do passado. Por outro lado, Hamlet, era um texto antigo que, apesar de ter sido feito no passado, trazia questões bastante atuais para reflexão.

Sabe-se que nessa montagem de Brook, o diretor altera e edita o texto com o objetivo de encontrar o ponto essencial de Hamlet, deslocando de posição inclusive o celebre monólogo "ser ou não ser". De acordo com o diretor, neste texto, a ação política não influencia diretamente as ações das personagens, de maneira que a discussão política não está na origem dos eventos. Assim o texto estaria mais próximo da tragédia do que de uma crônica política sobre a sucessão do trono. Brook (apud BANU, 200I) explica que, segundo seu ponto de vista, o príncipe dinamarquês já se mostrava bastante chateado e, ao saber sobre o assassinato do pai, sua condição apenas piorou.

Existe uma especulação sobre um suposto enlouquecimento verdadeiro da personagem, porém não é confirmado em nenhum momento do texto. Shakespeare evidencia a situação em que Hamlet se encontra, e não sua loucura. Sua dificuldade essencial é decorrente do fato de que, por um lado, está completamente lúcido e age normalmente e, por outro, está excepcionalmente triste com a situação em que se encontra. Para o encenador Hamlet quer ter certeza e reforçar suas ideias sobre as palavras do fantasma e tem a possibilidade de realizá-lo graças ao espetáculo que organiza com os atores itinerantes que passam pelo reino. A religiosidade do príncipe é abalada pelo fato de saber que seu pai está sofrendo no Purgatório (BROOK, apud BANU, 200I).

Com a confirmação do ato de assassinato, na cena metalinguística do texto, a ideia do além com todas as suas sanções se comprova para Hamlet e torna-se uma realidade da qual ele não tinha mais nenhuma dúvida. Então, quando o fantasma solicita vingança, fazendo com que o príncipe mate alguém, algo que é contrário à sua natureza, gera um conflito que faz com que pense e entre em conflito a respeito da situação. Este é basicamente o conflito de toda trama. Questiona se o que havia visto seriam as suas fantasias, ou se as forças do demônio tomaram a forma de seu pai e o induziam a realizar algo tenebroso.

Apenas com a chegada da trupe de atores à corte é 
possível que Hamlet manipule os comediantes e faça uma peça para ter certeza sobre os atos do seu tio, conferindo assim as provas necessária à confirmação do seu ato. Neste caso o próprio Hamlet é responsável por armar a trágica armadilha. A partir da prova obtida, "o homem de guerra prevalecerá sobre o homem de paz” (BANU, 200I, p. 283). Em relação às mudanças propostas pelo diretor e seus colaboradores, a última cena expôs bastante do pensamento sobre a visão de Hamlet. Todos estão mortos, inclusive os que foram vítimas da conspiração do Rei Claudio.

Neste universo atingido pela morte, o encenador optou por não fazer com que ninguém chegasse de fora. Desse modo não é Fortimbrás que toma o reino da Dinamarca. Na encenação Horácio, o único sobrevivente, profere as falas do início do espetáculo dizendo: "Quem está aí?" Brook indica que Shakespeare, ao longo de seu trabalho, afirmou que há algo mais forte que a morte: a vida. E com a montagem de $A$ Tragédia de Hamlet, não é a morte que tem a última palavra, mas a vida. Em sua opinião, Fortimbrás seria a tradução do militarismo de um jovem ditador que chega para organizar o caos que se instaurou no reino da Dinamarca, pois nada se sabe ao seu respeito. Nem as suas qualidades humanas e nem a sua visão política (BROOK, apud BANU, 200I).

Desse modo, conferindo uma situação diferente, optou por finalizar o espetáculo com a última réplica de Horácio o amigo do príncipe e a testemunha da tragédia. Para Brook (apud BANU, 200I), Horácio estaria mais próximo do público e seria a personagem que tem quase a mesma visão sobre a vida pretendida pela direção, o que encerraria a encenação de forma bastante apoteótica e cheia de esperanças. Como resposta à pergunta: "Quem está aí?", o encenador queria que a vida fosse restaurada pelas palavras de Horácio, mesmo que estivessem repletas de incertezas.

$\mathrm{Na}$ opinião de Brook (apud BANU, 200I) a personagem não tem a arrogância das certezas de Fortimbrás. Sendo assim ele simplesmente fala e as demais personagens se levantam. Então finaliza o espetáculo com algumas indagações: Quem são eles? Eles estão vivos? Estão mortos? Perguntas estas que permitem que se discuta a questão do aperfeiçoamento do ser humano a caminho de se tornar melhor em sua trajetória de aprimoramento espiritual.

Entretanto Brook sempre foi destemido na busca por novos significados, por ideias maiores. Algo que pudesse estar além do trivial. Nunca satisfeito, não se incomodava com desafios, dificuldades ou críticas que surgiam devido aos seus esforços, nada ortodoxos, para encontrar uma estética mais refinada que expressasse os mistérios do espírito humano, mesmo que exigisse a edição e o corte da obra-prima de Shakespeare. Ele segue o seu próprio caminho. E é justamente este o 
estilo de direção de Brook: a transparência, o cenário simples e organizado, o uso impecável da cor, a beleza essencial da mise-en-scène - e o que atrai atenção das críticas: "estava tudo lá, visível no momento em que se entrou no teatro" (CROYDEN, 2003, p. 253).

\subsection{A SIMBOLOGIA DO TAPETE VERMELHO - CENÁRIO DE ATRAGÉDIA DE HAMLET.}

A encenação de mais de duas horas não apresenta nenhuma complexidade em relação a opção espacial, bem como não apresenta nenhum efeito técnico para seu desenvolvimento. Brook enfatiza a simplicidade e busca, desta maneira, atingir a força teatral necessária ao texto. Explica que, enquanto ensaiava o espetáculo $O$ homem que confundiu sua mulher com um chapéu, observou o cenário e percebeu que havia somente quatro cadeiras e uma mesa e pensou que seria 0 suficiente para desenvolver $\circ$ espetáculo sobre a história de Hamlet.

Assim o pensamento que conduziu os trabalhos para a concepção espacial e estrutural de A Tragédia de Hamlet foi implementado também com base em dois conceitos que Brook tem experimentado desde a formação do CICT: a exploração do espaço vazio e os carpet shows. Desta maneira é possível expor que se tratava de um espaço com características minimalistas, composto apenas por um tapete retangular, vermelho cor de sangue, que cobria o círculo frontal do espaço do Théâtre des Bouffes du Nord.

De acordo com o que vimos nos capítulos anteriores, essa configuração espacial permitia que houvesse uma maior proximidade entre os atores e o público, de forma que havia uma grande imersão na narrativa shakespeariana, bem como permitia um estímulo grande à criatividade dos espectadores.

Os únicos objetos que compunham a cenografia do espetáculo eram: algumas almofadas; dois pequenos tablados revestidos de vermelho, que funcionavam como bancos e estavam dispostos de maneira geométrica (figura 58); duas varetas que serviam como espada; uma taça; e, duas caveiras para a cena dos coveiros. No total eram seis almofadas: verde, amarela, índigo e preta, que estavam espalhadas ao redor do palco. Os tablados, que serviam de assentos para os atores, possuíam rodas, de modo que poderiam ser facilmente alterados pelos atores para compor diferentes formatos, de acordo com a necessidade da cena. A responsável pelo desenho do espaço cênico também foi Obolensky, que desenvolveu ainda os figurinos do espetáculo. 
Figura 58 - Foto do cenário proposto para A Tragédia de Hamlet (2000) no Théâtre Bouffes du Nord.

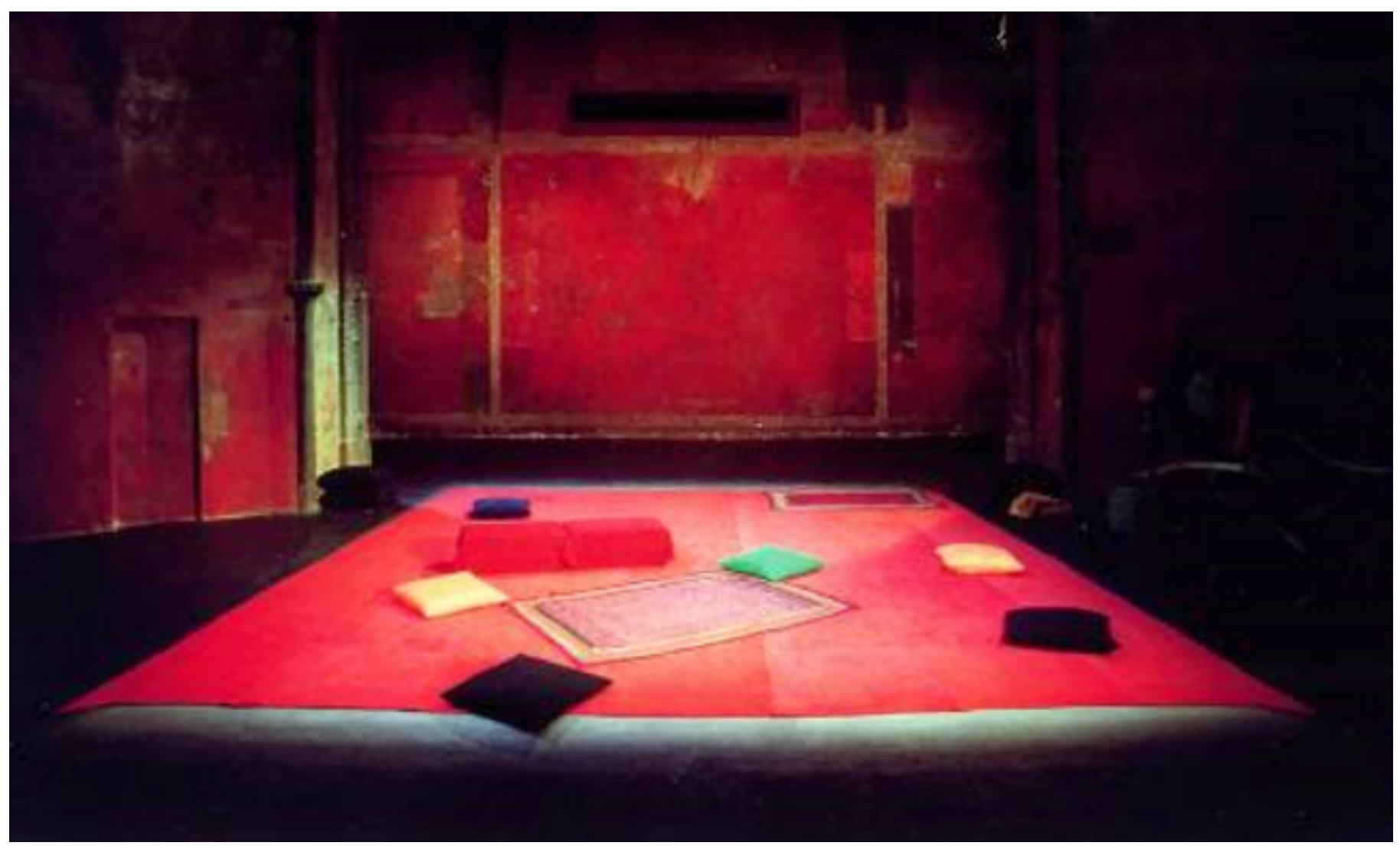

Fonte:Victor (2003).

Em momentos específicos, a iluminação contribuiu bastante para estabelecer uma atmosfera mais sombria. Em algumas cenas, tal como o momento de oração do Rei Cláudio, tio de Hamlet, que está pedindo sua redenção pela morte de seu irmão, o efeito das sombras reforça o desejo do protagonista em vingar-se pela morte de seu pai (figura 59). Outro momento em que também há um efeito de iluminação significativo é o início da cena dos atores que representariam "A Ratoeira", por exemplo. Porém, de forma geral, o ambiente criado a partir da iluminação era extremamente uniforme e antiestético. 
Figura 59 - Foto do efeito de iluminação quando Hamlet surpreende o rei Cláudio rezando em ATragédia de Hamlet (2000)

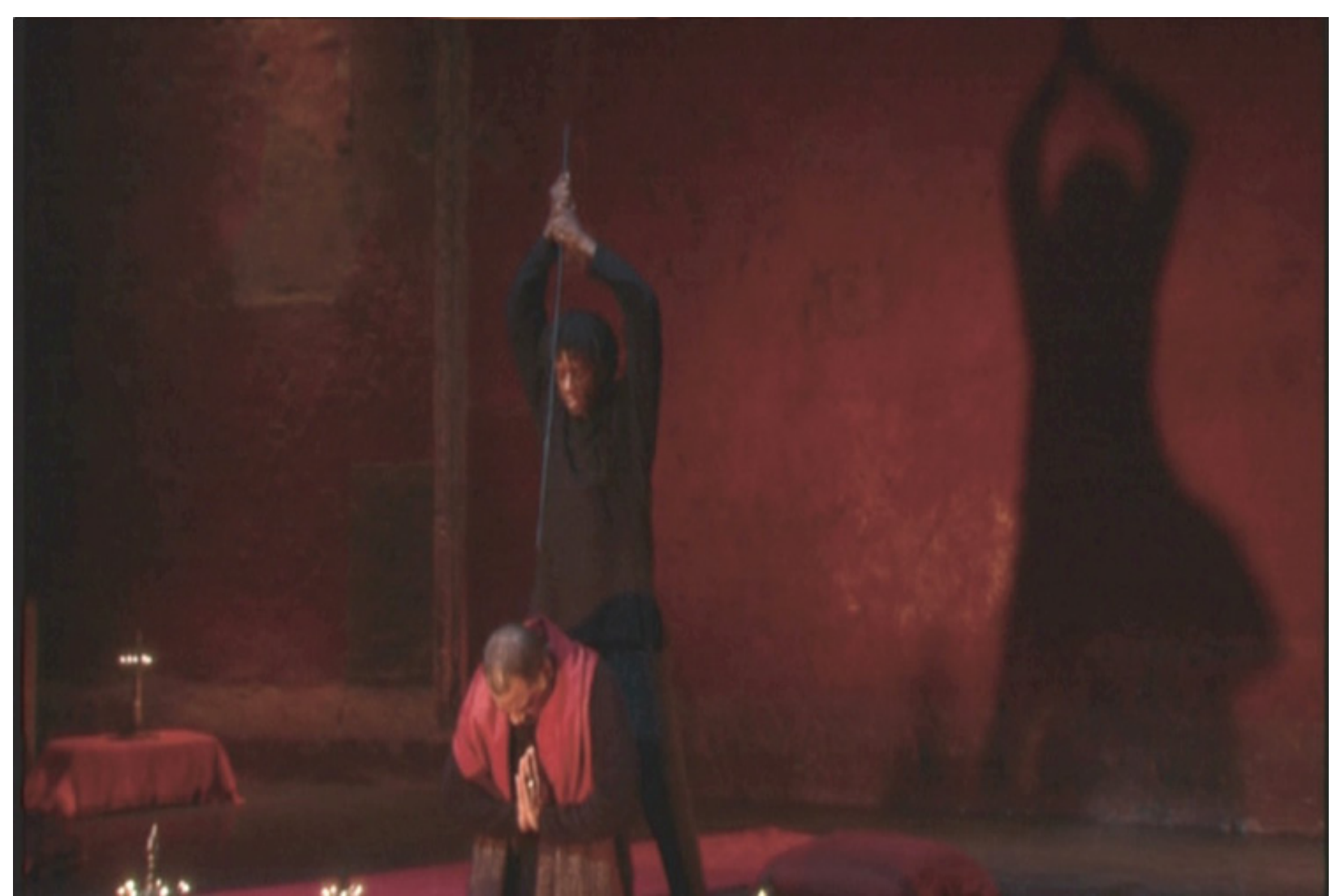

Fonte: Brook (2004).

Durante o espetáculo a movimentação dos atores ocorre pelas laterais ou pelos fundos e assim que deixam o tapete se encerra o jogo cênico. As entradas das personagens no espaço cênico são marcadas pelos instrumentos que são tocados em uma das laterais. Como já ocorreu em espetáculos anteriores, os músicos estão à vista dos espectadores, interagindo diretamente com a cena. Todos estes elementos permitem maior espaço à imaginação do público, pois aqueles apresentados no palco são extremamente simples e tornam essa interação possível. 
Da maneira simples como é apresentada a cenografia, é possível estabelecer uma direta relação com a simplicidade do palco elisabetano que efetivamente deixa $\circ$ ator em uma maior evidencia no decorrer da encenação, permitindo a exploração com grande destreza de um assunto de alcance humanista tão abrangente quanto esta obra. Neste sentido, o tapete servia como limite de palco evidenciando, novamente a importância dos carpet shows, explorados durante as viagens internacionais da companhia. Quando foram colocados neste espaço, percebeu-se que enfatizou ainda mais as questões e angústias abordadas no texto, reforçando justamente o objetivo da direção.

Assim como em 0 Jardim das Cerejeiras, o espaço do teatro em si não permaneceu isolado, de modo que na encenação de ATragédia de Hamlet o Théâtre des Bouffes du Nord também se tornou um invólucro adequado para o desenvolvimento do drama. A montagem se aproveitou do aspecto degradado do espaço teatral, que já chamava atenção, e compôs com as paredes pintadas de vermelho, complementando com a cor selecionada o espaço da representação. Essa estrutura reforçava a natureza lúgubre e "apodrecida" da corte dinamarquesa exposta pelo texto. Apesar da óbvia sensação de abandono, com suas velhas paredes cor de terracota, o palco parecia envolto por uma tonalidade avermelhada bastante intensa, que magicamente assumiu uma qualidade especial para essa corte retratada em
Hamlet (figura 60), e, inevitavelmente, faz referência ao sangue que será derramado com tantas mortes no decorrer do espetáculo. 
Figura 60 - Foto do cenário de A Tragédia de Hamlet (2000) envolvendo o espaço do Théâtre Bouffes du Nord no drama shakespeariano

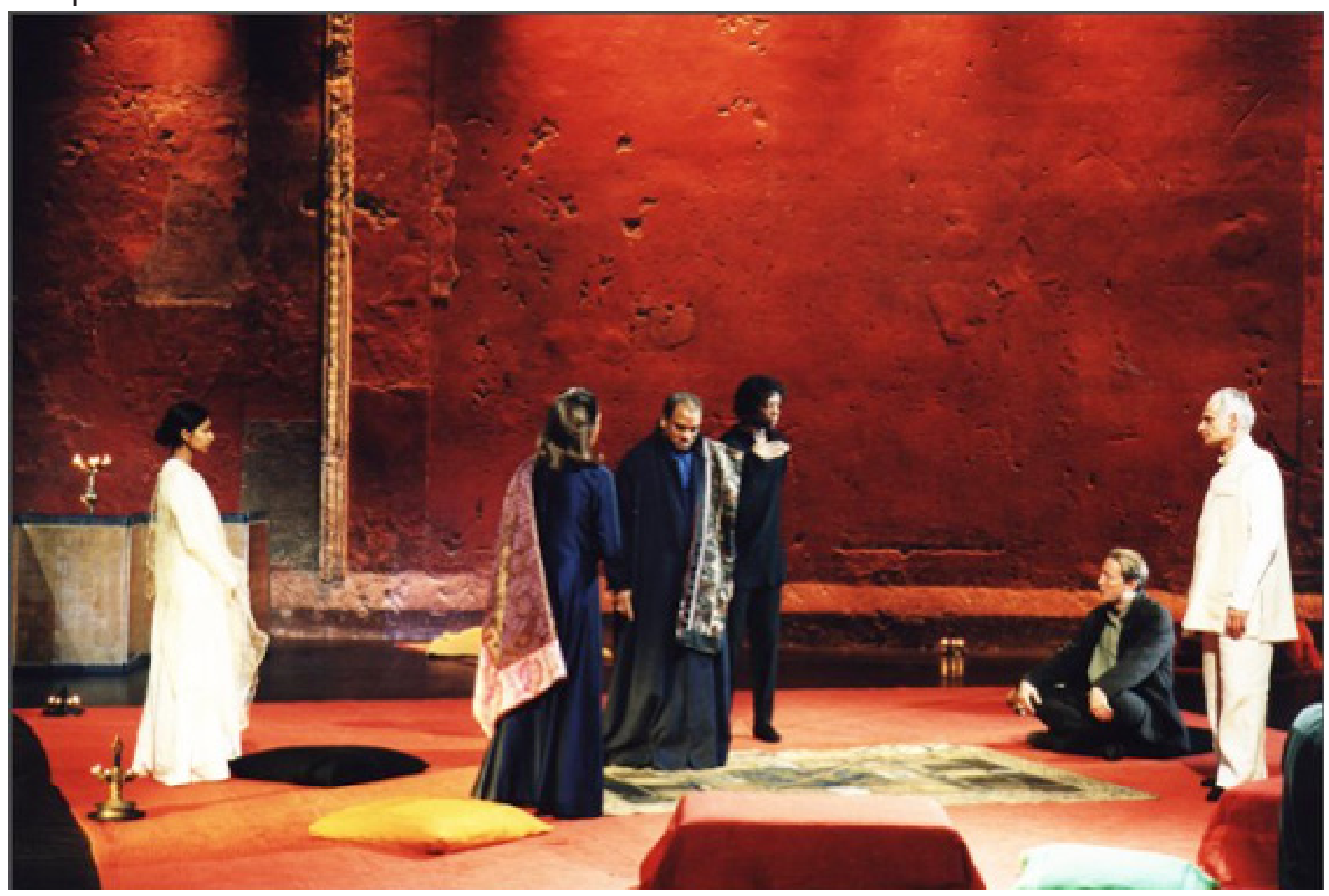

Fonte: Robison (200I).

Brook (apud TODD; LECAT, 2003) explica que, durante os ensaios, realizaram algumas experimentações com diferentes tapetes. Mas, tanto Brook como Obolensky tinham a sensação de que $\circ$ trabalho não estava ocorrendo do modo devido. Iniciaram sua pesquisa tentando o reaproveitamento de um grande tapete persa ornamentado que havia sido utilizado na montagem de Mahabharata, colocando-o sozinho no chão do palco. O fato de ser persa impunha algo de estrangeiro para Hamlet que não encaixava nas expectativas da direção.

Depois tentaram tornar o piso em um espaço único, 
com um grande carpete branco que cobria todo espaço de representação, porém não estavam satisfeitos com o resultado. A composição que havia sido a solução ideal para $O$ homem que, aparentava ser bastante simplória para Hamlet. Na sequência cobriram com tapetes marrons e beges, porém todas estas possibilidades sobrecarregavam o espaço vazio proposto, tornando-o inadequado para o que se pretendia com a atuação.

Em seguida Obolensky teve a ideia de usar uma plataforma de concreto rachado para o piso, o que combinaria perfeitamente com $\circ$ aspecto das paredes do Théâtre des Bouffes du Nord. Contudo Brook achava que era uma solução muito fria e tinha um aspecto muito bruto, o que eliminaria toda ludicidade e a energia que gostaria de explorar com o texto. Esse recurso também não pareceu ser muito prático para a movimentação de cena, uma vez que dificultava e restringia a liberdade de circulação dos atores, que não poderiam ajoelhar-se confortavelmente, ou sentar-se, fazer cambalhotas, ou cair no concreto sem se machucarem.

Essa solução ainda poderia se tornar, no contexto do espaço do Théâtre des Bouffes du Nord, um conjunto particularmente inadequado, já que o aspecto do concreto destruído iria se assemelhar a uma reprodução da degradação das paredes daquele espaço que já esteve em ruínas. Conferindo assim um conjunto naturalista bastante frio e um tanto quanto sinistro à encenação.
Definitivamente Brook não pretendia estabelecer essa atmosfera à sua nova versão de Hamlet, pois queria evitar trazer à tona o aspecto denso do drama medieval que geralmente é associado ao texto. Não desejava que fosse uma peça sombria. Em sua opinião se tratava de "uma tragédia, mas uma tragédia radiante" (TODD; LECAT, 2003, p. 228).

Com essa experimentação, ficou mais evidente a percepção de que o clima que se estava pretendendo explorar no palco, solicitava que houvesse alguma cor extremamente vibrante no palco. Tinham a sua disposição um pedaço de tecido indiano branco, que foi tingido de vermelho em uma destas experiências, e despretensiosamente cumpriu exatamente o propósito desejado. No ensaio experimentou-se retirar o tapete para o duelo final, mas esta situação criava um incômodo devido ao tempo consumido para a remoção do tapete, ao passo que também se percebeu que a peça funcionava melhor quando havia uma unidade espacial. Sobre a seleção do vermelho como cor base do ambiente do espetáculo, pode-se dizer que de acordo com a teoria das cores de Kandinsky (1996), não poderia ter sido uma opção mais acertada.

Dado que o foco de Brook era toda tragédia vivida por Hamlet, colocando-o como a personagem destacada em toda história, as características atribuídas ao vermelho se encaixavam perfeitamente com as de sua 
personalidade. Trata-se de uma

[...] cor sem limites, essencialmente quente, age interiormente como uma cor transbordante de vida ardente e agitada [...] transparece uma espécie de maturidade masculina, voltada, sobretudo, para si mesma e para a qual o exterior conta muito pouco (KANDINSKY, 1996, p. 97).
Também as opções de cores para as almofadas e bancos em cena, mesmo que tenham sido selecionadas arbitrariamente, revelam traços da personalidade rica e contraditória do protagonista shakespeariano. De acordo com o pintor elas transmitem o estado de espírito de: calma e tédio (verde); explosão, agressividade e loucura (amarelo); e, finalmente, tristeza, espiritualidade e passividade (azul), todos presentes em algum momento em Hamlet.

Figura 6I - Foto do cenário de A Tragédia de Hamlet (2000) com o tapete vermelho na diagonal e as almofadas usadas em cena no Théâtre Bouffes du Nord.

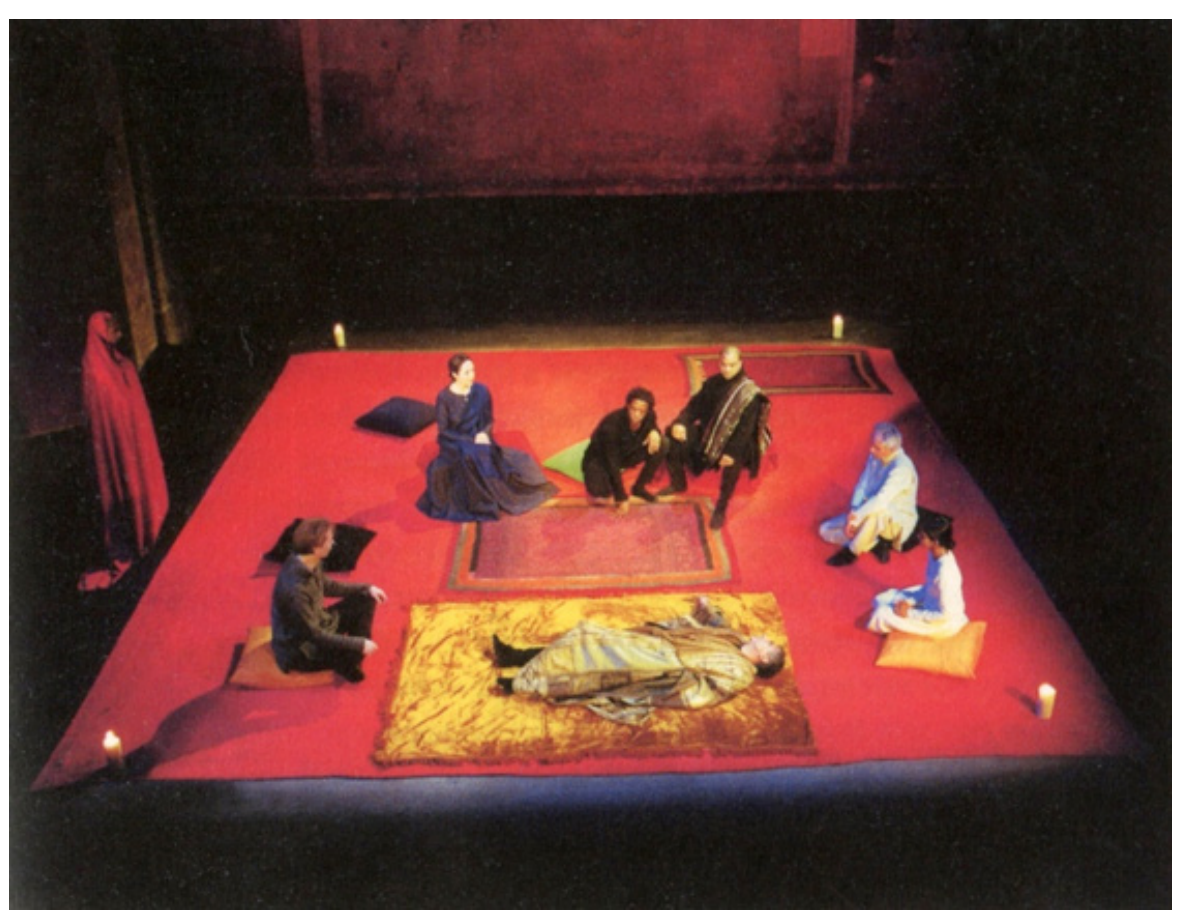

Fonte:Todd; Lecat (2003, p. 227) 
Embora não se tenha feito nenhuma alteração na cor avermelhada ou na estrutura das paredes, elas foram mencionadas em quase todas as críticas. Evidentemente tinha-se ciência que seu aspecto contribuía intensamente para abarcar a história da corte de Elsinore. Todavia provavelmente a cor determinada para o tapete foi responsável por ressaltar o apelo a elas conferido. Apesar de parecer uma solução bastante simples: colocar somente um tapete em cena, fazia com que Brook e sua equipe de designers levassem em consideração todos os aspectos no momento de conceber essa proposta espacial.

Além da influência da cor, deve-se atentar para a posição do tapete no espaço cênico. Em um dado momento optou-se por posicioná-lo diagonalmente em relação ao palco. Brook explica que essa condição foi embasada não somente no número de atores que estariam em cena ao mesmo tempo, como também nas possibilidades de movimentação e criação de espaços diferentes em cena.

Um monólogo pode ser encenado diretamente para frente, de forma muito simples, mas no momento em que há várias pessoas no palco é preciso criar os relacionamentos entre eles. Se o espaço é absolutamente nu, descobre-se que as possibilidades coreográficas para 0 teatro são rapidamente esgotadas. [...] Se você usar apenas um quadrado sem bordas, os atores podem se mover para a direita, esquerda e meio, e então rapidamente se torna chato, porque nada se renova visualmente. Em Hamlet descobrimos que precisávamos de objetos, a fim de articular o espaço, para trazer diagonais, movimentos circulares, de modo que as pessoas podiam estar próximas, juntas, ao longe (BROOK apud TODD; LECAT, 2003, p. 229).

O diretor explicita que a melhor forma de explorar as soluções de movimentação espacial da cena é "no início de ensaios é trabalhar com móveis simples, como cadeiras" (BROOK apud TODD; LECAT, 2003, p. 229). Contudo, no caso de Hamlet, ao se introduzir cadeiras, provavelmente, se perderia a agilidade de cena, criando o mesmo efeito cênico indesejado que a retirada do tapete na cena do duelo, durante os ensaios. Precisavam de objetos leves que pudessem ser facilmente removidos e manipulados durante a cena. Pensou-se, então, que não seria necessário nada além de almofadas para realizar as mudanças desejadas.

Bastaria que os atores as carregassem consigo durante a sua movimentação de cena para que outro ambiente se estabelecesse. Dessa forma foram confeccionadas seis almofadas coloridas. Não satisfeitos com a solução simples, decidiram colocar rodas em outros objetos como os tablados, para que pudessem ser facilmente empurrados para as diferentes posições, configurando assim novos ambientes. Durante os ensaios descobriram 
que todos os espaços propostos pelas diferentes cenas poderiam ser resolvidos apenas com dois suportes. Ao criar uma partitura de movimentação cênica, conseguiuse preencher todo tempo de espetáculo sem que se reparasse nos padrões de configuração elaborados somente com estes poucos objetos.

Sobre o tamanho pretendido para a área de representação, Brook (apud TODD; LECAT, 2003) declara que, quando começaram os encontros para a montagem do espetáculo, a ideia era usar novamente todo o espaço do palco do teatro, sem uma área determinada. A intenção era, de alguma forma, retomar o conceito colocado no início de seu texto O espaço vazio. "O que aconteceria se não houvesse absolutamente nada, se alguém andasse neste vasto espaço, e pouco a pouco se trouxesse o que é preciso?" (TODD; LECAT, 2003, p. 230). Contudo, receava-se cair no lugar-comum de que eram necessários grandes espaços para se fazer jus à grandeza desta obra prima de Shakespeare.

Durante a apresentação de uma companhia estrangeira em seu teatro, que interpretava The Island, de Athol Fugard, John Kani e Winston Ntshona; o diretor atentou que eles estavam representando todo espetáculo em uma plataforma bastante reduzida, com as proporções de cerca de um quarto das dimensões utilizadas comumente nas áreas de encenação dos espetáculos do CICT. Desse modo, constatou-se que a redução espacial proporcionava uma intensa concentração na cena e que este poderia ser um caminho interessante para a montagem do espetáculo.

Quando começaram a ensaiar Hamlet, Brook queria experimentar trabalhar em um espaço um pouco reduzido em relação ao que estavam acostumados. Ao testar essa condição nos ensaios, observou que para a primeira cena do Fantasma com Hamlet a redução se encaixou perfeitamente, pois tornava a cena ainda mais emocionante. Porém essa mesma situação não funcionava com as demais sequências do espetáculo. Sendo assim, analisou-se a possibilidade de deixar o tapete um pouco maior. Mas, ainda assim com tamanho mínimo necessário para conseguir um efeito mais intimista.

A vantagem de uma área um pouco maior é que seria possível realizar todo o espetáculo neste espaço sem que houvesse interrupções. Por exemplo, Bruce Myers que interpretava Polônio, deixava Ofélia, andava ao redor do palco e quando o rei Cláudio aparecia do outro lado, já se convencionava que estariam na cena seguinte. Brook explica que se o espaço de representação fosse menor, provavelmente essa transição se tornaria cômica. Era tudo uma questão de proporcionalidade, de equilíbrio e bom senso - e, evidentemente, sabedoria, vivência e experiência teatral. 
Antes de se atentar à concepção dos figurinos do espetáculo, é relevante evidenciar que houve um certo desconforto da cenógrafa e figurinista na proposta final dos elementos visuais de A Tragédia de Hamlet. Apesar de ter sido bastante elogiada pela crítica, Obolensky, durante entrevista para o autor desta tese na época do mestrado, disse que teve a sensação de que a solução proposta para a peça já havia sido utilizada em outros espetáculos da CICT. E ela não gostaria de ter chegado novamente a um resultado semelhante. Expôs que desejava ter pesquisado mais profundamente a temática e ter chegado a um desenho distinto.

Obolensky declarou na época que Brook trabalhava recorrentemente com $\circ$ tapete como elemento de delimitação do palco. Para a cenógrafa, essa solução tinha sentido em $O$ Jardim das Cerejeiras, uma vez que naquele conjunto, auxiliava para compor a paisagem impressionista desejada pela montagem do espetáculo. Assim como em Mahabharata, pois os tapetes eram objetos usados com muita frequência na Índia e auxiliavam na definição dos diferentes ambientes que eram propostos durante a extensa representação do épico. Mas em Hamlet ela diz que seu desejo era de ter realizado uma intervenção distinta do usual tapete (figura 62). 
Figura 62 - Foto do cenário proposto para A Tragédia de Hamlet (2000) na cena dos atores.

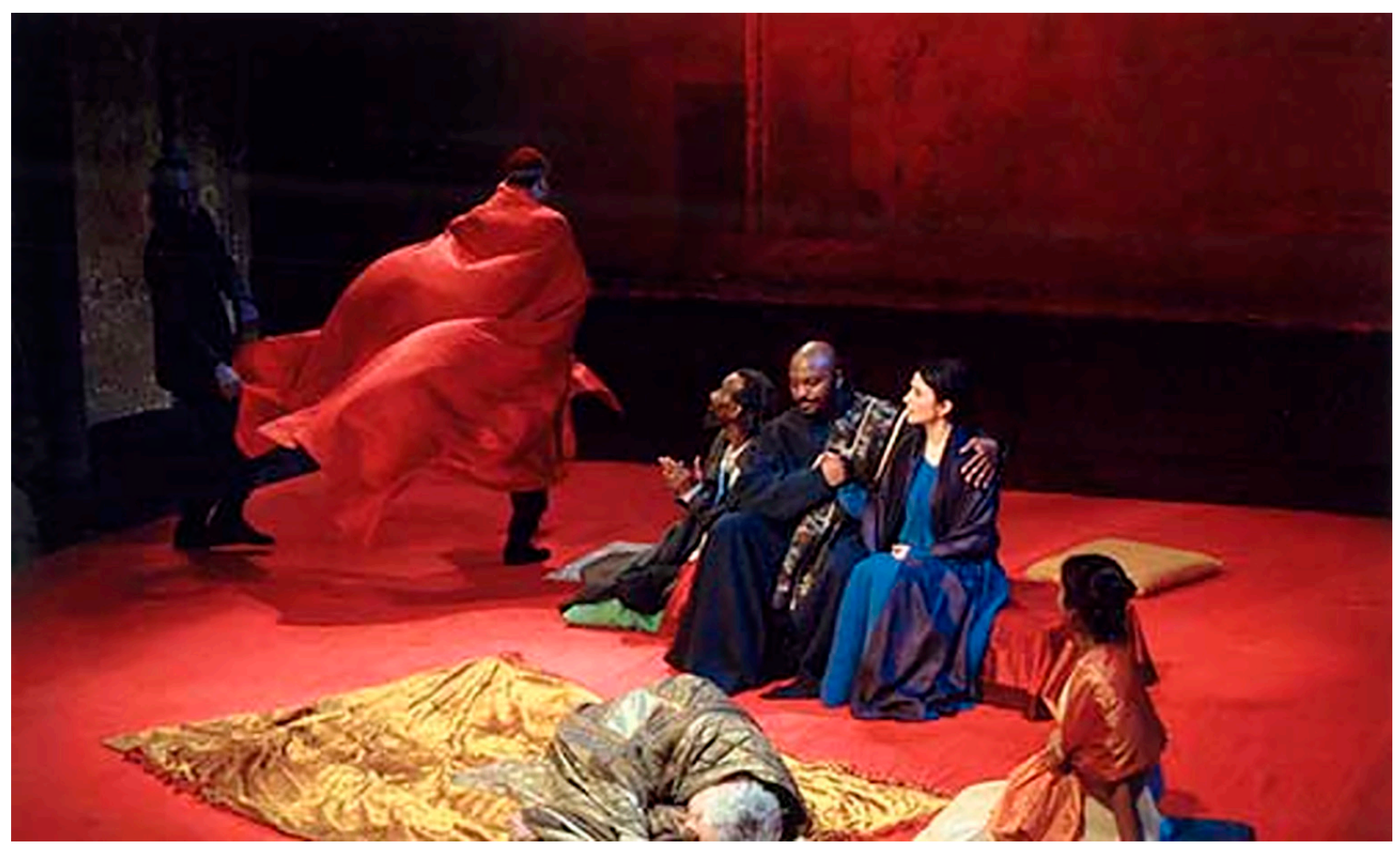

Fonte:Victor (2003)

Reconheceu que essa proposta tinha sentido no contexto de exploração do espaço cênico do diretor inglês e que, de certo modo, também se tratava de uma evolução do seu processo criativo, contudo sugere que, diferentemente do diretor, não é por se tratar de uma solução simples que, sobre o seu ponto de vista, essa seria a solução mais adequada. Ela afirma que não acha que, por ter sido uma solução simples, seria a solução mais interessante para o espetáculo, pois gostaria de ter encontrado uma proposta diferenciada ${ }^{16}$.

${ }^{16} \mathrm{~A}$ entrevista feita pelo autor desta tese com a cenógrafa e figurinista Chloé Obolensky, ocorreu no ano de 2012 durante a realização do mestrado. Para leitura na íntegra, consultar: ORTIZ, Sergio Ricardo Lessa. Do espaço vazio ao círculo aberto: rumo à cenografia e indumentária sagradas de Peter Brook. 20I3. Dissertação (Mestrado em Teoria e Prática do Teatro) - Escola de Comunicações e Artes, Universidade de São Paulo, São Paulo, 2013. 
Provavelmente essa discordância sobre a solução para a cenografia fez com que esse fosse o último trabalho de Obolensky junto com Brook. É provável, também, que conforme exposto durante a pesquisa, a solução proposta para este espetáculo, dada a simplicidade de elementos em cena, seja de fato a consagração da busca de Brook pelo sagrado durante sua trajetória profissional. E que, dessa forma, tenha conseguido efetivamente atingir o ponto pretendido em relação à experimentação espacial de seus espetáculos. Como veremos a seguir, essa condição de atingir o ponto máximo da imaginação e simplificação dos elementos visuais do espetáculo só foi obtido devido a combinação da proposta cenográfica com os desenhos dos trajes de cena.

\subsection{OS TRAJES DE CENA DE A TRAGÉDIA DE HAMLET-CONSOLIDAÇÃO DA SIMBOLOGIA NAS VESTIMENTAS}

Para caracterizar as diferentes personagens em cena, os atores somente contavam com alguns tecidos e o tapete que estava no palco. Em A Tragédia de Hamlet é evidente a busca por certa neutralidade no resultado visual das personagens. Quando começaram a ensaiar, Brook havia dito a Obolensky, responsável pelos figurinos do espetáculo, que não queria roupas contemporâneas, pois, desse modo, chegaria a um estado que gostaria de evitar ao máximo: o clichê.

$$
\begin{aligned}
& \text { Quando eu comecei a realizar } \\
& \text { produções das peças de Shakespeare, } \\
& \text { era comum colocar a peça em outro } \\
& \text { período. Mas, atualmente se fizer } \\
& \text { isso próximo ao estilo vitoriano, } \\
& \text { ou medieval, ou qualquer outro } \\
& \text { semelhante a estes, é algo que já foi } \\
& \text { visto centenas de vezes. E que se } \\
& \text { tornou, por essa repetição excessiva, } \\
& \text { um clichê (BROOK apud CROYDEN, } \\
& \text { 2003, p. 265). }
\end{aligned}
$$

Então, começou-se a pesquisa em busca de trajes que não remetessem ao contemporâneo, e que também não fossem de época, mas que apresentassem uma leve sugestão do passado, medieval ou renascentista. Como se trata de uma tragédia, as roupas deveriam ter cortes contidos e serem simples, sendo praticamente impossível revelar seu período histórico. Obolensky, portanto, desenhou trajes, nem renascentistas, nem modernos, nem africanos, nem asiáticos, nem parisienses ou dinamarqueses, mas buscou algo que fosse inidentificável em sua época e origem. A partir desse desejo, conseguiu atingir e materializar um conceito buscado por Brook ao longo de sua incansável pesquisa teatral: o sagrado.

Apesar de alguns críticos terem atribuído aos trajes de cena um resultado mais próximo ao atemporal, a figurinista não concorda que seja esse o resultado obtido com os cortes de formas simples. Para 
Obolensky, quando se diz que o figurino é "atemporal", provavelmente estaria se referindo a que ele não pareça estar ligado a um momento na história. "Por duas razões: eles não querem que pareça datado, ou não gostam da ideia de figurinos de época. Pois, pode parecer que é falso ou que pareça falso, ou pode conduzir os atores a uma direção diferente do que está sendo proposto para a cena" "17. Durante a entrevista realizada por este pesquisador ela exemplifica que a atemporalidade é consequência do contexto no qual está inserido o espetáculo.

Brook declarou que sempre teve uma grande necessidade de ter cores fortes em suas produções. Para ele existia uma tendência natural da figurinista de "ir sempre para o preto, branco e cinza, pensamos em fazer trajes com formas simples, muito funcionais, apenas evocando o fato de não ser sobre o dia de hoje" (BROOK apud TODD; LECAT, 2003, p. 229)

Decidiu que a composição de cores deveria ficar a cargo do que estava fora da personalidade das personagens. No ambiente que as envolve, ou seja, no uso das almofadas e na cor do chão. Então toda a vitalidade visual que o jogo precisava veio dos objetos, tapetes e tecidos, ao invés dos figurinos. As cores nos trajes dos atores foram orquestradas de modo a compor a cena com tons sóbrios: preto, branco, tons de cinza e, quando tivessem cores, que fossem mais frias, neutras ou pastéis.

Para Obolensky, o único traje que conseguiu atingir esse resultado esperado foi o de Hamlet. Ele estava vestido completamente de preto, com uma bata que remetia a um período mais renascentista (figura 63), porém sem colocá-lo especificamente como uma figura do passado. A escolha do preto para seus trajes tem total relação com o luto pelo pai.

Em contraponto ao traje de Hamlet, temos Ofélia com um longo vestido branco, liso, com corte retilíneo e com mangas compridas (figura 64). A opção pelo branco "puro" provavelmente está ligada, tanto ao conceito de pureza e esperança, colocados por Kandinsky (1996), quanto à atribuição da morte evocada pelas culturas orientais. Ofélia carrega a ingenuidade e a pureza consigo durante o drama shakespeariano.

${ }^{17}$ Informação disponível na entrevista feita pelo autor desta tese com a
cenógrafa e figurinista Chloé Obolensky, no ano de 2012. Para leitura na cenógrafa e figurinista Chloé O 
Figura 63 - O ator Adrian Lester no solilóquio ‘ser ou não ser’ em A Tragédia de Hamlet (2000).

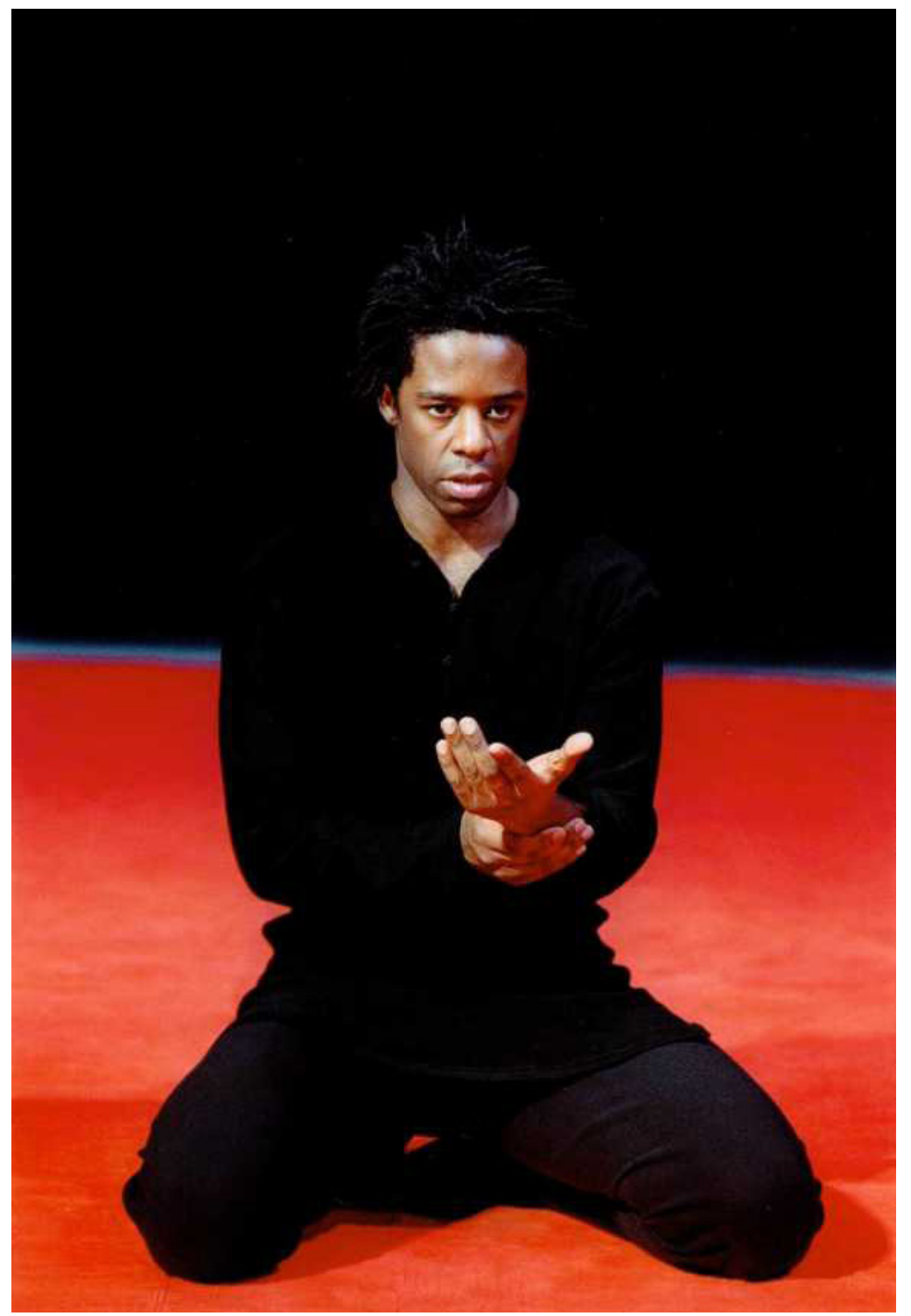

Fonte: Victor (2000). 
Figura 64 - As atrizes Shantala Shivalingappa e Natasha Perry como Ofélia e rainha Gertrudes em A Tragédia de Hamlet (2000).

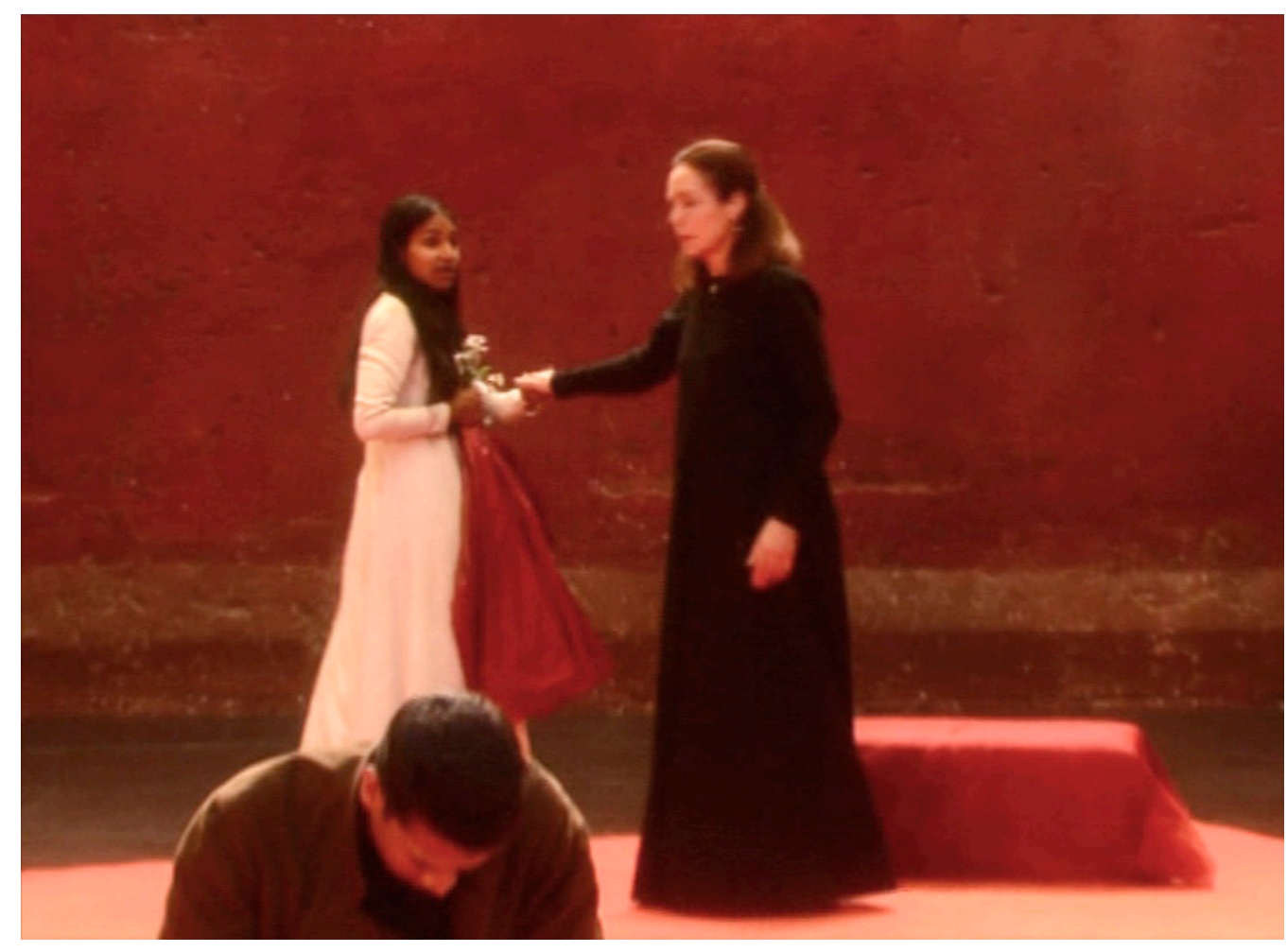

Fonte: Brook (2004)

Contudo Ofélia não é uma personagem linear, ela também nutre em si desejos e paixões e uma vontade intensa de viver. Obolensky e Brook perceberam essa necessidade e, na cena em que Hamlet a manda para o convento, ela entra envolvida em uma túnica vermelha que, como já foi visto na elaboração dos cenários, é exatamente símbolo de transbordamento de vida, de alegria e energia, segundo o pintor.

Os atores não usavam maquiagem, nem perucas. Mantiveram os seus cortes de cabelos como o faziam usualmente. Brook desejava que o estado natural dos atores estivesse representado no palco. Talvez o aspecto mais interessante dessa produção tenha sido a capacidade de sugerir elegância e realeza sem nenhum 
apetrecho cênico ou qualquer adorno real. Contavase somente com a elegância do desenho dos trajes e com a alta qualidade dos atores. Brook fez questão de limar todas as cenas de corte; somente permaneceu uma cena que foi adaptada à percepção do príncipe. E, mesmo assim, os críticos e espectadores se imbuíam do universo proposto.

Ao observar os trajes de cena do espetáculo, comparado aos trajes expostos anteriormente, fica nítida a trajetória de simplificação dos desenhos propostos para as personagens, o que expõe a observação sobre o processo de simplificação da composição dos trajes. Com menos elementos conseguem fazer com que o espectador seja conduzido ao universo em que o invisível se comunica com o público. Assim, deve-se concordar com Foix (2008) que A Tragédia de Hamlet é uma verdadeira realização do Teatro Sagrado defendido por Brook em 1968.

Para Foix (2008) essa peça conseguiu colocar em cena, por meio de uma síntese minimalista de concepção teatral, a poética teatral de Brook: de que tudo pode ser reduzido à ação física e física-verbal do ator. Embora sempre tenha contado com excelentes atores, é na proposta minimalista de $A$ Tragédia de Hamlet que a poética colocada em cena radicaliza sua concepção de aparatos cênicos, uma vez que havia uma quase absoluta ausência de acessórios cenográficos; a cena era despojada de objetos e os figurinos que eram extremamente simples e bastante significativos. Sendo assim, abriram caminho para a experiência a ser vivenciada pelo ator e pela imaginação do espectador.

Naquele momento se revelou o processo de construção do espetáculo de Brook, em que o essencial é ser simples. Jean-Guy Lecat ${ }^{18}$, que foi assistente de cenografia de Brook por muitos anos, em entrevista ao pesquisador, disse que: "Simplicidade não é apenas não ter nada no palco, é algo muito mais complexo que isso".

${ }_{18}$ Jean-Guy Lecat concedeu entrevista para o autor desta tese no ano de 20I2, durante a realização do mestrado. Para leitura na íntegra, consultar: ORTIZ, Sergio Ricardo Lessa. Do espaço vazio ao círculo aberto: rumo à cenografia e indumentária sagradas de Peter Brook. 2013. Dissertação (Mestrado em Teoria e Prática do Teatro) - Escola de Comunicações e Artes, Universidade de São Paulo, São Paulo, 2013. 


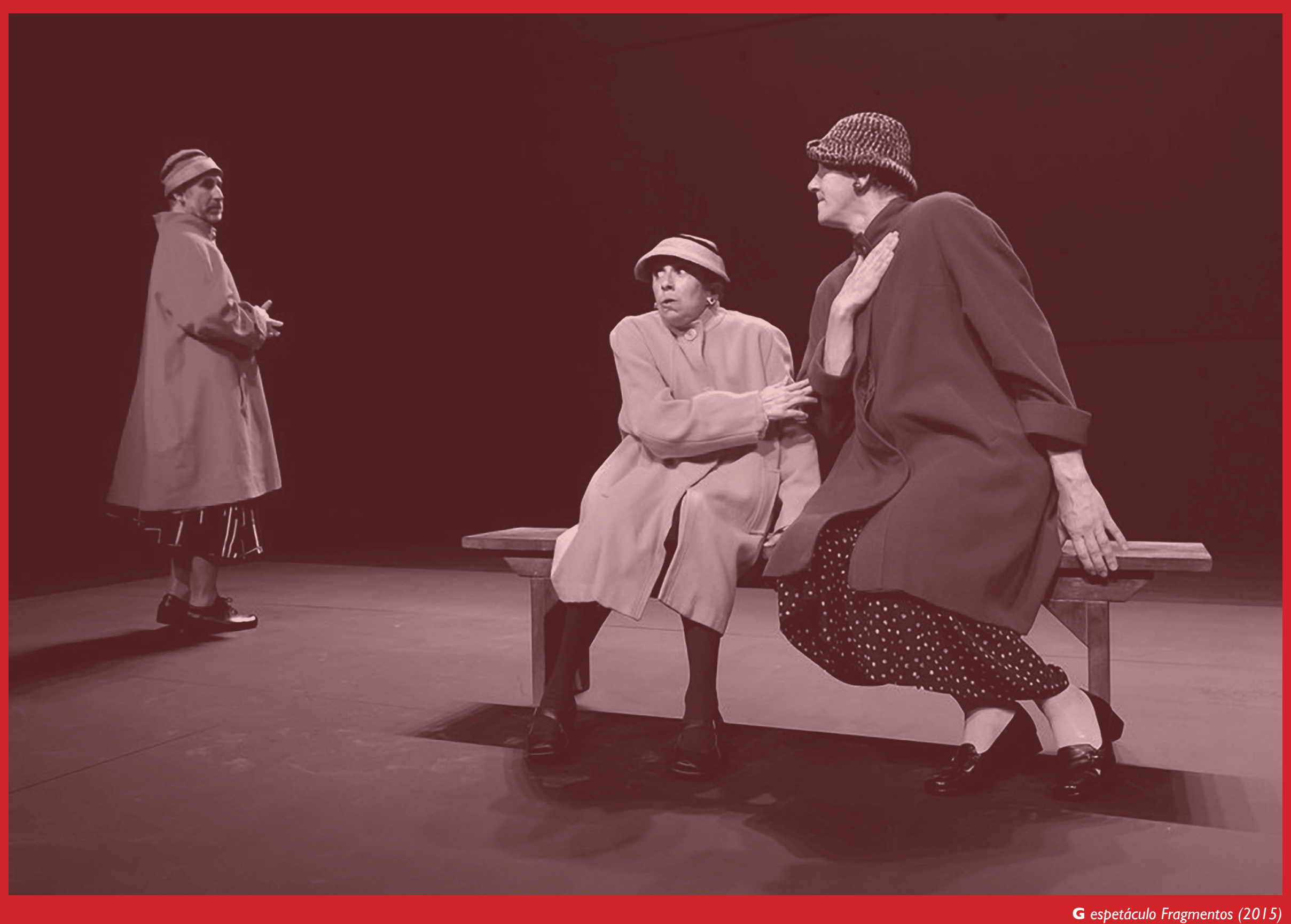





\section{CONSIDERAÇÕES FINAIS}

Peter Brook é hoje um senhor de 95 anos e o acesso a ele não é, de modo algum, simples. Sua família o preserva do contato com a maior parte dos pesquisadores que o procuram e assim aconteceu comigo desde o mestrado, em que ele já era tema da pesquisa.

Ainda assim, em um último esforço antes da finalização efetiva desta tese, em seu prazo regulamentar, escrevi para Peter Brook no dia 28 de janeiro de 2020 fazendo uma única pergunta:

Em sua opinião, o senhor acredita que haja uma relação entre o processo de simplificação dos cenários e figurinos e também sobre o espaço de atuação na medida em que como ser humano o senhor evoluiu no processo espiritual?

A questão era, de maneira resumida, a hipótese desta tese, como apresentada na Introdução do trabalho. No dia 12 de fevereiro de 2020 recebi a seguinte resposta de Peter Brook: "Se você escolher o caminho da simplicidade, inevitavelmente mais e mais tudo daquilo que não é necessário desaparece".

Ao final de quatro anos completos de pesquisa, duas linhas resumem de forma simples toda a trajetória de Peter Brook e, de maneira aprazível, esta pesquisa.

Em 2015 assisti no Théâtre des Bouffes du Nord a montagem Fragmentos de Samuel Beckett dirigida por Brook. Ele havia percebido que, com o passar do 
tempo, haviam sido atribuídos falsos rótulos ao escritor Samuel Beckett no passado - de que ele seria triste, negativo e desesperado. Nessa montagem, procurava atrair a realidade da existência humana, com bastante humor. Assim, estabeleceu um espetáculo utilizando os seguintes fragmentos dos textos de Beckett: Fragmento de teatro I, Cadeira de Balanço, Ato sem palavras II e Ir e Vir.

Todo espetáculo seguia a trajetória de Brook em explorar as ideias do texto provocando a imaginação dos espectadores com poucos elementos. O palco permanecia sem adornos e os cenários eram realizados com poucos objetos manipulados pelos próprios atores enquanto se preparavam para a cena seguinte. Nesse processo Brook explorou o tom introvertido que encontrava nos textos de Beckett. Na história das três velhas senhoras que trocavam fofocas sobre os seus anos de juventude, o cenário era composto por um banco e as personagens estavam vestidas com roupas do dia a dia, porém cada uma em uma tonalidade de vermelho, compondo, assim, um degrade de cores que revelavam bastante sobre a personalidade de cada uma. Em outro trecho dois homens viviam em sacos de lixo e repetiam à exaustão de ações irrelevantes, explorando as feições de clown, conferindo comicidade à situação trágica em que se encontravam.

Neste texto os atores estavam vestidos com ternos escuros e carregavam os sacos de lixo brancos que eram manipulados em cena, de modo a tornar o impacto do texto com leveza e humor. Finalmente, em uma das sensações mais impressionantes vividas no teatro, se iniciou o texto Cadeira de Balanço, em que a atriz Kathryn Hunter conseguiu fazer com que os espectadores tivessem uma experiência única com sua atuação no palco. Este tex to foi escrito por Beckett como se fosse um poema performativo sob a forma de um espetáculo teatral. Trata-se de um drama lírico no qual a linguagem que se escutava oferecia aos espectadores uma importante informação sobre a imagem que se via, mas também a descrevia de forma rigorosa e precisa. Uma metáfora visual que se materializava diante dos olhos da plateia ao mesmo tempo em que se assistia à encenação do poema.

Beckett escolheu colocar em cena uma mulher sentada em uma cadeira de balanço que interagia por meio da imaginação do público com própria experiência de vida, e, também, com a memória pictórica dessa figura que estava sentada na sua cadeira e falava sobre a vida. Uma das sutilezas psicológicas do texto, que se esperava das suas intérpretes é que conseguisse, por meio da linguagem, transmitir o balançar da cadeira em um movimento uníssono com seu corpo em cena, fato que parecia, à primeira vista extremamente simples, porém conferia dificuldade adicional a quem decidisse realizar o texto. 
$\mathrm{Na}$ encenação Brook optou por não colocar efetivamente em cena uma cadeira de balanço, mas uma cadeira simples, que era manipulada pela atriz de modo que se imaginasse efetivamente uma cadeira de balanço, - que conferia uma dificuldade adicional para Hunter. Ela entrou em cena com um traje bastante comum sapato de salto preto com formato convencional, saia preta e veste um longo casaco cinza escuro, e se sentou nesta cadeira de madeira com design bastante simples (figura 65). Tanto o posicionamento da cadeira como a intensidade da iluminação milimetricamente calculados pela direção, conduzia o espectador para um mergulho naquela realidade repetitiva do texto, que indicava uma conformação com a morte que chegará para todos.

Figura 65 - Foto do espetáculo Fragmentos (2015) - trecho de Cadeira de Balanço no Théâtre des Bouffes du Nord.

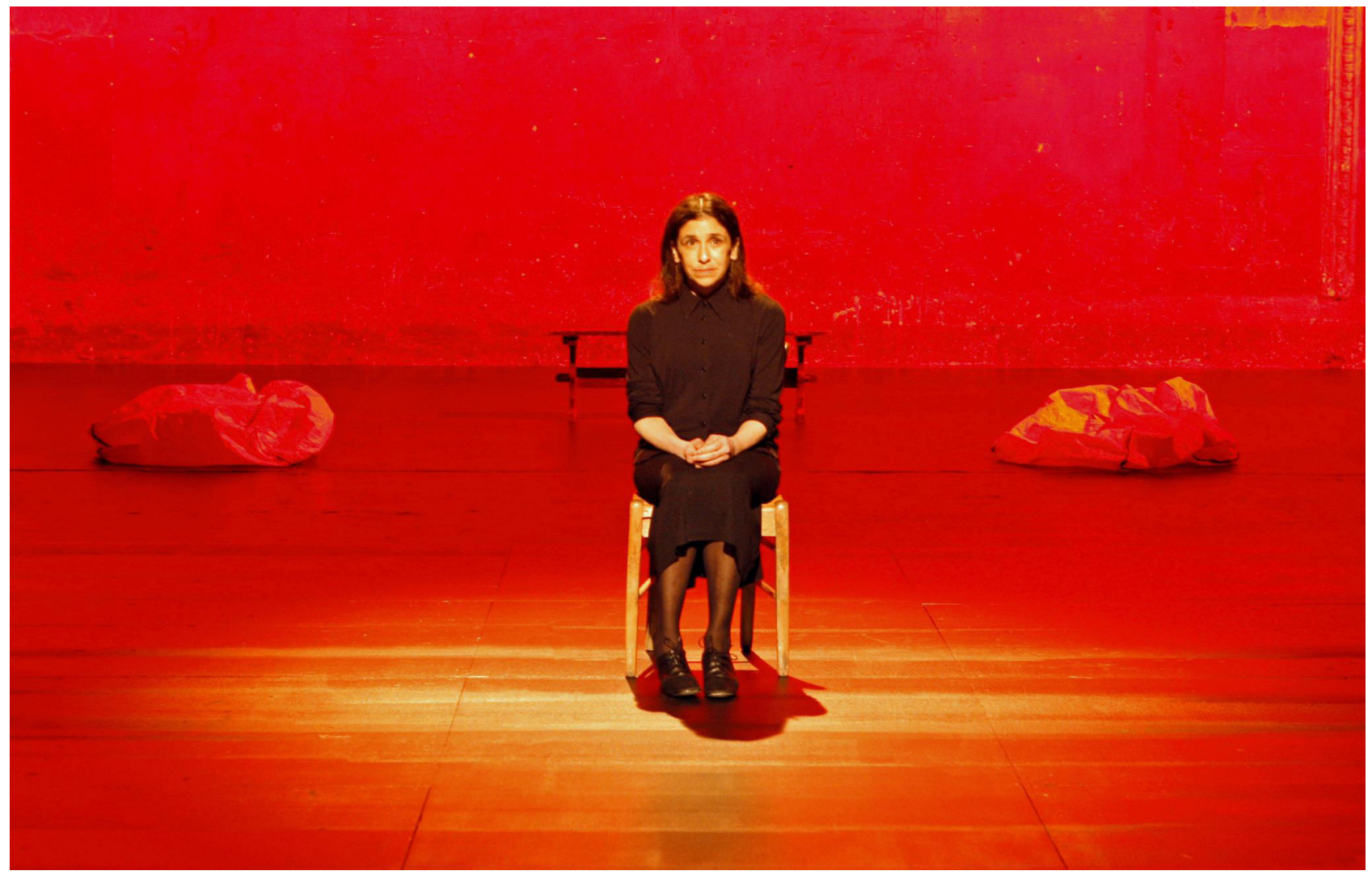

Fonte: Nadais (2009). 
Deve-se ressaltar que a atriz estava sentada exatamente no centro do palco do Théâtre des Bouffes du Nord. No local exato que Brook falou se tratar do ponto em que os atores tinham uma maior proximidade com o público. A luz foi desenhada para a cena com um spot focado na atriz sentada na cadeira. Conforme o texto era proferido, a penumbra se configurava com o apagar suave das luzes. Este efeito fez com que o público tivesse uma atenção maior sobre a atriz em cena que praticamente não se movia, mas com o embalar do texto conseguia definitivamente representar a sensação do balanço da cadeira. Até que em um momento mágico, quase ao final do texto, senti-me sugado para dentro do palco.

Nunca havia sentido essa sensação. Foi algo transcendental e inexplicável. Ao final do espetáculo perguntei ao meu marido, que me acompanhou nessa experiência, o que havia sentido. Para minha surpresa tinha sido a mesma sensação descrita anteriormente. Sendo assim, foi possível comprovar, de fato, que Brook tinha um domínio impressionante do seu espaço de representação. Sabia onde colocar os atores para que se atinja o objetivo pretendido, bem como conseguia trabalhar com a imaginação da plateia de modo primoroso com poucos e seletos elementos visuais, cuidadosamente selecionados para tocar a alma de seus espectadores.

\section{NO CAMINHO DA SIMPLICIDADE, DESNECESSÁRIO DESAPARECE}

Brook sempre foi bastante reservado e cauteloso em relação ao seu envolvimento com as teorias de Gurdjieff. Contudo, ficou evidente ao longo do trabalho que nunca houve uma negação do processo de aprofundamento sobre o conhecimento de si e as relações com a transformação na espacialidade. Gurdjieff, em seus ensinamentos, também colocava uma questão aos seus seguidores, que era justamente o processo de simplificação da vida para compreender o que há de essencial em nossas almas. Neste sentido, a afirmação de Brook - "Se você escolher o caminho da simplicidade, inevitavelmente mais e mais tudo daquilo que não é necessário desaparece" - indica que sua trajetória como encenador caminha no exato sentido de se tornar mais simples, e, portanto, mais próxima de atingir o essencial.

Por meio da pesquisa compreendeu-se que o caminho percorrido por Brook, desde a descoberta do trabalho desenvolvido por Gurdjieff, quando teve seu primeiro contato com a proposta do mestre greco-armênio ao ler uma crítica sobre o livro do misterioso guru, até sua transferência e estabelecimento em Paris, com a morte de sua primeira mentora Jane Heap, foi fundamental para que a pesquisa do encenador no conhecimento sobre si mesmo e, consequentemente, na iniciação 
sobre o seu aprimoramento espiritual pudesse começar a refletir na sua trajetória artística. Brook revelou que sua transferência para a cidade luz, de fato, foi conduzida pela necessidade de aprofundar as técnicas desenvolvidas pelo grupo liderado por Gurdjieff em busca do processo de desperta-se do estado de sono.

Deste modo, pode-se dizer que o falecimento de Heap foi o estopim para que se afirmasse no diretor a necessidade de verticalizar seu aprimoramento espiritual. Assim, poderia estar mais próximo de sua nova mentora, Madame Jeanne de Salzmann, que vivia em Paris, e ao mesmo tempo conviver com a fonte direta dos ensinamentos, uma vez que ela havia convivido diretamente com Gurdjieff e aplicava, no início do século, as técnicas descobertas nas peregrinações pelo Oriente. Compreendeu-se, portanto, que até a transferência para a França, Brook evitou ao máximo abordar em seus trabalhos qualquer temática que estivesse relacionada com a questão da espiritualidade. Apesar de em alguns momentos, já ficarem mais nítidas as relações entre os exercícios de investigação cênica e algumas técnicas de aprimoramento espiritual.

Procurou-se evidenciar relações entre a espiritualidade buscada e aplicada por Brook e traçar relações com - processo de desenvolvimento cênico de outros importantes encenadores tais como Stanislávski e Grotowski. No caso de Stanislávski há uma evidente relação entre o sistema estabelecido pelo diretor russo e as técnicas do yoga, sobretudo: na aplicação de técnicas de respiração; na utilização de alguns elementos essenciais como a liberação muscular, a comunicação e irradiação de prana; no aprimoramento da atenção e concentração durante as cenas; na utilização de processos meditativos para acesso às imagens e visões interiores; e, finalmente, no superconsciente como forma de relacionar o inconsciente ao estado criativo.

Sabe-se que os trabalhos sugeridos por Gurdjieff, em muitos aspectos, também se apoiaram nos ensinamentos do yoga e em conhecimentos antigos explorados pelo Islã, além da teosofia. Outro encenador que igualmente possui um significativo suporte no aprimoramento da espiritualidade e com o qual Brook teve um intenso contato e desde o final da década de 1960, quando já habitava a sede da CICT, foi o diretor polonês Grotowski, do qual sofreu bastante influência. Vimos como Grotowski colocava os demais elementos da encenação como totalmente desnecessários, ou seja, para ele os cenários, os trajes de cena, as maquiagens e os efeitos cênicos seriam decorativos e supérfluos. O Teatro poderia existir perfeitamente sem estes elementos, mas não poderia existir sem que houvesse uma relação direta com a vida exposta pelo ator.

De acordo com Pavis (20l I), a investigação estética em direção ao teatro pobre tanto em Grotowski quanto em 
Brook (com o teatro rústico), e o desejo de alcançar a abstração, por vezes, conduziu estes dois encenadores a eliminarem gradualmente os cenários, na medida em que isto fosse possível, visto que o palco, mesmo vazio, sempre apresentava alguma proposição, ainda que fosse apresentado esteticamente desnudo. Sendo assim, qualquer elemento teria significado mesmo que estivesse ausente. Neste contexto, o cenário estaria presente mesmo que fosse compreendido apenas pela articulação das palavras do ator (cenário verbal), ou na gestualidade do ator, ou ainda pelo modo como indicariam os elementos visíveis.

Da aproximação entre as propostas de Brook e Appia, destacamos a eliminação de todos os elementos que não traziam nenhum significado para o fazer teatral. Ambos preferiam que 0 palco estivesse livre, para que assim pudessem trabalhar com o exercício da imaginação dos espectadores. Interferiram no espaço dos espectadores, na sala de espetáculos, de modo a permitir que houvesse uma maior sintonia com o que se transmitia em cena. Além disso, vale destacar que a iluminação cênica também foi responsável por delinear de modo significativo o fazer teatral de ambos. Contudo Brook trabalha de modo distinto, priorizando a relação de intervenção cênica no plano horizontal, leva em consideração a movimentação dos atores como forma de atingir o sagrado e pensa que a luz é fundamental para a composição do espetáculo.
Por sua vez, quando apresentamos as relações com Craig, evidenciamos que apesar de em um primeiro momento, Brook apresentar um protesto em relação a maneira como ele realizava a pintura cênica por meio da luz, superestimando a importância do spotlight, no livro Avec Grotowski (BROOK, 20II), afirma que o seu precursor londrino tinha uma visão artística absolutamente voltada para a beleza e pureza, ressaltando os seus desenhos desenvolvidos evidenciando a cenografia que achava ideal. Nesse sentido, Brook também não privilegia nenhum dos elementos do jogo cênico, trata todos com a devida importância.

Craig estava em busca da perfeição, no entanto, Brook não via a possibilidade de encontrá-la no teatro comercial. Brook (20II) afirma que a semelhança entre sua abordagem e a proposta de Craig, estava pautada no processo de eliminação. Pela trajetória de Brook, percebe-se que a supressão de determinados elementos refletiu diretamente na confecção dos elementos visuais da cena. Esta decisão de supressão foi adquirindo, ao longo do tempo, características mais simbólicas para revelar ao espectador, as mais profundas e reais intenções dos autores dos textos com a menor quantidade de artefatos possível.

Durante a pesquisa ficou explícito que Brook trabalhou sempre a elaboração dos elementos visuais do espetáculo a partir de uma intuição que era expressa 
durante as primeiras leituras do texto, geralmente registrada por meio de palavras indicativas ou de esboços da proposta de cenografia e trajes de cena. Em seguida, experimentava os elementos com os atores durante os ensaios, e finalmente excluía aquilo que era desnecessário para o entendimento da mensagem - chegando a resultados muitas vezes minimalistas ou simbólicos para todos elementos visuais. Desse modo, visava expressar o máximo de verdade em relação aos conteúdos abordados pelos autores utilizando o mínimo de recursos possível ou seja, limava de cena exatamente o que não era o essencial para a comunicação com o público.

Brook sempre partia do espaço cênico vazio, quase sem elementos, para a elaboração de uma montagem teatral. Desse modo, o espaço vazio, por ser extremamente simples, possibilitava a criação de qualquer projeto espacial, desde que fosse trabalhado adequadamente com os significados e estímulos para à imaginação dos espectadores. Alguns padrões se confirmam. $O$ primeiro era o palco estar despojado de quaisquer elementos decorativos e, nesse sentido, os espaços vazios propostos se encaixavam plenamente com as ideias do diretor. Em seguida, e decorrente desta primeira afirmação, é possível constatar que há uma tentativa de atingir o imaginário do espectador: como - espaço geralmente estava livre de informações, há uma abertura significativa para que a plateia possa complementar as informações por meio de seu próprio processo criativo.

Assim como Appia, era fundamental para o processo de criação cênica de Brook compreender a relação entre os corpos dos atores, uma vez que seus corpos têm volumes específicos e se movimentam pelo espaço cênico. $O$ intuito era estabelecer a relação mais adequada possível à percepção do público de modo a envolvê-lo no contexto do universo a ser explorado pela encenação. Por meio da investigação e exploração empírica do espaço, descobriam qual era a relação ideal a partir das proporções do espaço do Théâtre des Bouffes du Nord, para conferir a proximidade necessária para envolver os espectadores no imaginário pretendido.

Sobre os trajes de cena, deve-se atentar para o fato de que o figurino é o responsável por situar os espectadores sobre a época e o local onde se passa a encenação. Em vista disto, as análises dos espetáculos permitiram compreender que houve uma adequação das propostas dos trajes em relação a corroborar na transmissão da mensagem pretendida. Portanto, quando se tratava de espetáculos em que era preciso revelar o momento histórico, havia uma pesquisa consolidada sobre $\circ$ período abordado.

O mesmo se pode afirmar em relação aos aspectos culturais que serviam de base para ambientação do 
espetáculo. Nesse sentido, é relevante destacar que sempre houve uma busca pela síntese da impressão que se tem com as referências histórico-culturais, ainda que os trajes de cena fossem inspirados em trajes sociais de época, como foi o caso da indumentária de 0 Jardim das Cerejeiras. Ressalta-se, também, a importância do significado das cores nos trajes, pois estas tinham relação direta com as características das personagens que as vestiam.

Os cenários, nas propostas realizadas por Brook, somente eram desenvolvidos caso se identificasse a necessidade de complementação de alguma informação que não fosse transmitida pelos demais elementos cênicos. Mesmo que não houvesse a necessidade da construção de um cenário, era indispensável o debate com os cenógrafos durante os ensaios. Até para que se tomasse a decisão sobre a sua não utilização. Ainda que não se construísse um cenário com muitos elementos, o espaço de representação sempre carregava alguma intenção, mesmo que se concentrasse no plano horizontal com intervenções no piso do palco. Em diversos momentos o diretor cogitava a simples delimitação do espaço de encenação dos atores com elementos simbólicos que agregassem à estrutura do texto.

A posição de um ator em relação aos outros no palco também tinha um intuito específico; neste quesito, houve um intenso estudo de Brook no sentido de compreender a forma como a relação ator-espectador poderia se tornar mais efetiva a partir do posicionamento dos atores no palco. Para a plateia, quando se diz "ser ou não ser”, há uma posição específica que torna mais expressivo o proferir das palavras da personagem, de modo que, o espectador é induzido a participar da peça, mesmo que esteja somente observando em uma posição passiva a encenação. Brook estudava intensamente qual seria a distância correta para dizer qualquer texto ao público.

No processo de concepção de Brook, foi possível compreender que há um direcionamento em relação à linguagem cenográfica escultórica, ou seja, não pensa na concepção do espetáculo por meio de elementos visuais bidimensionais. Dessa forma tudo o que é utilizado na encenação deve ser desenvolvido em uníssono, em uma criação coletiva em que somente se utiliza aquilo que for essêncial, para elaborar a unidade do espetáculo.

De modo a tornar viável essa proposição cenográfica era fundamental que houvesse uma sintonia afinada entre Brook e seu cenógrafo. Em Tip of the Tongue (2017), indicou que a tradição teatral e os antigos hábitos continuavam a encher o espaço de representação de itens desnecessários com muita decoração e excesso de objetos e adereços. Dessa maneira não havia espaço para a imaginação do espectador. Sugere que o espaço 
vazio devesse ser encontrado a partir da oposição a esta condição.

Hoje em dia, o vazio é um desafio desconfortável para o diretor e para o escritor, bem como para o ator. Um espaço pode ser deixado aberto, além do que se pensa, acredita e deseja afirmar? Todas as páginas das peças de Beckett são iluminadas com parêntesis em torno da palavra 'Pausa'. Tchekhov indicou o espaço em que o inexprimível poderia aparecer - com reticências... E Shakespeare cercava cada fala com espaço. O teatro existe para que o não dito possa respirar e uma condição de vida possa ser percebida, o que dá um motivo à uma luta sem fim (BROOK, 20I7, p. 70-7I).

Neste sentido, o vazio foi para o diretor sempre o ponto de partida, para descobrir aquilo que era efetivamente essencial como suporte para dar apoio à riqueza das palavras definidas pelos dramaturgos e à presença do ator. Brook (2017) explica que a melhor expressão de vazio é o silêncio. Para o diretor, um pequeno grupo em um pequeno espaço pode criar algo inesquecível, porém, quando existem mais pessoas envolvidas, a energia se torna mais vibrante, e é possível atingir mais vitalidade no fazer teatral. Sugere que o teatro, limitado em espaço e tempo, pode provocar importantes mudanças na vida das pessoas que vão assistir a um espetáculo.
Em sua opinião, toda forma de teatro deveria ter um impacto na vida do público, pois na saída, era preciso que as pessoas se sentissem necessariamente melhores $\mathrm{e}$ transformadas com a peça que acabaram de presenciar. Nesse aspecto, insinua que há algo de esotérico e profano na encenação. "Em todo Shakespeare, há um movimento natural que vai do esotérico ao profano. Algo é aberto e, em seguida, deliberadamente trazido para a vida cotidiana" (BROOK, 20 I7, p. 83-84). Segundo suas convicções, há atualmente um temor em relação a denominar qualquer experiência como espiritual, o que ressalta, novamente, o cuidado que Brook tem ao se aproximar dessa temática.

Em suas produções, portanto, houve uma significativa alteração no processo de construção do espaço e dos elementos visuais. Em A Conferência dos Pássaros (1979), Brook realizou uma primeira aproximação com uma temática espiritual em cena. Nessa proposta, mesmo utilizando a menor quantidade de elementos possíveis, percebe-se uma tentativa de reprodução, tanto nos trajes de cena, quanto nos elementos do cenário, de referências do cotidiano de uma aldeia do Senegal.

Dessa forma há uma utilização de objetos e trajes realistas, na tentativa de induzir o espectador no universo proposto no texto. Identificou-se nessa montagem o resgate da experiência vivida nas expedições realizadas pela CICT pela África, Irã e América do Norte, em que 
o grupo se apresentava para as pessoas locais sobre um tapete, o que ficou conhecido como carpet show, o que se tornaria um espaço de encenação fundamental ao longo da trajetória de Brook.

O Jardim das Cerejeiras, estreado pelo grupo em 1981, atingiu um novo patamar de exploração em relação a simplificação visual do espetáculo. Alguns elementos cênicos da montagem anterior permaneceram, como o reaproveitamento do carpet show mediante a reutilização dos tapetes persas. Contudo a alteração significativa na elaboração da cenografia foi a ressignificação do espaço de representação. Optou-se por conferir protagonismo para este espaço, de modo que o Théâtre des Bouffes du Nord se tornou também parte da peça como sendo a materialização da casa degradada de Ranévskaia.

Para envolver a plateia nesse contexto, os tapetes chegavam até os pés dos espectadores, tornando assim, todo o espaço na íntegra, parte da composição dos cenários. Entretanto, este avanço em relação ao caráter simbólico atingido pela proposta do cenário não se traduziu ainda nos trajes de cena. Obolensky decidiu, junto com Brook, pela reprodução dos trajes naturalistas indicados no texto. Deve-se destacar que os registros da figurinista contribuíram expressivamente para o sucesso da montagem do último texto de Tchekhov, uma vez que se optou por essa quebra na reprodução realista-naturalista dos figurinos.
Em A Tempestade, de 1990, o diretor teve logo no início dos ensaios do espetáculo uma inspiração de fazer ressignificar a delimitação do espaço de representação com a execução de uma nova proposta para o tapete. A partir desse insight, criaram uma caixa de areia em que seria possível registrar a movimentação dos atores em cena. Um tanque de areia definido por bambus na borda e uma pedra conferiram profundidade aos espectadores. A cenografia tornou-se, mesmo que contrária às afirmações de Brook, em um jardim zen oriental, que mostrava toda movimentação dos atores em cena. E, ao final do espetáculo, esse registro era apagado indicando que estavam prontos para uma próxima jornada da peça.

A Tempestade tornou nítido o processo de simplificação dos elementos visuais no espetáculo, valendo-se apenas do acréscimo, durante a narrativa, de pequenos objetos de cena que serviam como elementos simbólicos para estimular a imaginação do público a embarcar nesse contexto fantástico descrito por Shakespeare. Houve, também, um avanço em relação à redução dos elementos naturalistas nos trajes de cena, o que indica, definitivamente, o rumo tomado por Brook na realização dos elementos visuais dos seus espetáculos, em direção à síntese. Porém, ainda que fossem pontuais, persistiram poucas referências de construção naturalista-realista nos figurinos dos personagens históricos do texto. 
Foi durante a análise do processo de elaboração do espetáculo ATragédia de Hamlet (2000), que se percebeu, na trajetória de Brook, o domínio dos elementos simbólicos no processo de criação dos elementos visuais dos seus espetáculos teatrais. Nesse espetáculo, o diretor arriscou inclusive ao ajustar a ordem do texto, considerado como a obra prima do escritor inglês William Shakespeare, com o objetivo de atingir de forma mais contundente e profunda a essência do texto original. Foi memorável, ainda, a ousadia de fazer o espetáculo todo falado em língua inglesa para um público francês, bem como colocar um ator negro para dar vida ao príncipe da Dinamarca.

Em relação ao cenário e aos figurinos do espetáculo, destaca-se a nova versão de delimitação do espaço de representação. Porém, dando continuidade aos espetáculos anteriores, houve um ganho simbólico significativo, pois a cor e o posicionamento do tapete vermelho se destacavam das escolhas corriqueiras do diretor. $O$ vermelho, neste contexto, marca toda força, fervilhar de ideias presentes nos pensamentos do protagonista, bem como o sangue que está prestes a ser derramado na trágica história de Hamlet. A cor demonstra, ainda, todo transbordamento de vida, impetuosidade, energia e paixão que permanecem nas ideias, em ebulição, do protagonista. É importante destacar que neste caso, mais que em outras montagens, houve uma preocupação em relação ao posicionamento do ator no momento de proferir seus principais solilóquios.

Observa-se que as paredes do Théâtre des Bouffes du Nord complementavam as cores do tapete, pois permaneceram vermelhas depois da montagem de Mahabharata, o que reforçou a seleção das cores pela direção e cenógrafa. Em relação aos demais espetáculos, este foi o trabalho que fez com que Brook atingisse - Teatro Sagrado e parte dessa afirmação se dá, pois houve um redirecionamento em relação aos trajes de cena como participe da composição dos elementos visuais do espetáculo. Há uma efusiva supressão dos traços realistas tanto nos cenários como nos trajes de cena de A Tragédia de Hamlet.

Embora se questione sobre a atemporalidade dos figurinos propostos, conforme era o desejo da figurinista e do diretor, é possível afirmar que estavam muito mais próximos das características simbólicas. Proporcionaram a identificação das intenções dos atores pelos recortes e cores dos trajes, evitando qualquer relação com os trajes sociais históricos da época shakespeariana. Estes são verdadeiros indícios de que Brook atingiu a simplificação dos elementos visuais nesta proposição cênica.

No intuito de comprovar a hipótese desta tese, na qual se questiona sobre o Teatro Sagrado na trajetória de Peter Brook, foi possível compreender, por 
meio da aprofundada pesquisa realizada, que a busca pela espiritualidade impactou, significativamente, na simplificação da cenografia e na elaboração dos trajes de cena propostos pelo diretor. Assim, esse processo corrobora a transformação da apropriação espacial e valorização do espaço cênico nas encenações do diretor analisadas neste trabalho, uma vez que, há um nítido encaminhamento em relação à utilização de menos elementos naturalistas-realistas e, portanto, uma maior proximidade com a exploração da imaginação do espectador, que simbolicamente realiza as associações pretendidas pela direção. 


\section{REFERÊNCIAS}

ARONSON, Arnold. Olhando para o abismo. O Percevejo Online - Periódico do Programa de Pós-Graduação em Artes Cênicas PPGAC-UNIRIO, Rio de Janeiro, vol. 8, n. I, p. I49-I7I, jan./jun. 2016. Disponível em: http://200.156.24.158/index.php/opercevejoonline/article/view/5765/5398. Acesso em: 26 jul. 2019.

BACHELARD, Gaston. A Poética do Espaço. São Paulo: Martins Fontes, 2000.

BANU, Georges. Peter Brook: De Timon d’Athènes à Hamlet. Paris: Flammarion, 200 I.

L'Os et La Conferénce des Oiseaux: mise en scéne de Peter Brook. In: BABLET, Denis (ed.). Les voies de la création théatrale - tome 10: Krejca-Brook. Paris: Éditions du Centre National de la Recherche Scientifique, 1982. p. 25I-296.

BANU, Georges; MARIENTRAS Richard. Timon D'Athènes de Shakespeare: et as mise en scène par Peter Brook. In: BABLET, Denis ; JACQUOT, Jean (ed.). Les voies de la création théatrale - tome 5: William Shakespeare, Théâtre du soleil, John Arden, Samuel Beckett. Paris: Éditions du Centre National de la Recherche Scientifique, 1977. p. 3 I-I 20.

BARBA, Eugenio; SAVARESE, Nicola. A arte secreta do ator. Campinas: Editora Hucitec, 1995.

BERNARD, Elodie; FERREIRA, Mireille. Entretien avec Jean-Claude Carrière: La Conférence des oiseaux (Mantiq at-Tayr). La Revue du Teheran, n. 53, abr. 2010. Disponível em: http://www.teheran.ir/spip.php?article I I62\#gsc. tab=0. Acesso em: 19 jan. 2020.

BERTHOLD, Margot. História Mundial do Teatro. São Paulo: Perspectiva, 200 I.

BLOOM, Harold. Hamlet: Poema ilimitado. Rio de Janeiro: Objetiva, 2004.

Shakespeare: a invenção do humano. Rio de Janeiro: Objetiva, 2001.

BONFITTO, Matteo. A Cinética do Invisível: processos de atuação no teatro de Peter Brook. São Paulo: Perspectiva, 2009.

BROOK BY BROOK: Portrait Intime. Direção: Simon Brook. Produção: Arte France Développement. France: Arte Vídeo, 2004, I DVD. 
BROOK, Peter. Tip of the tongue: reflections on language and meaning. Londres: Nick Hern Books, 2017.

. Reflexões sobre Shakespeare. São Paulo: Sesc São Paulo, 2016.

Avec Grotowski. Brasília: Teatro Caleidoscópio: Editora Dulcina, 201 I.

. $\mathrm{O}$ espaço vazio. Lisboa: Orfeu Negro, 2008.

A porta aberta: reflexões sobre a interpretação e o teatro. Rio de Janeiro: Civilização Brasileira, 2005.

Evoking and forgetting Shakespeare. Nova lorque: Theatre Communications Group, 2003.

Fios do tempo: memórias. Rio de Janeiro: Bertrand Brasil, 2000.

Between two silences: talking with Peter Brook. Dallas: Southern Methodist University Press, 1999.

O ponto de mudança: quarenta anos de experiências teatrais: 1946-1987. Rio de Janeiro: Civilização Brasileira, 1994.

O diabo é o aborrecimento: conversas sobre teatro. Porto: Asa Portugal, 1993a.

O ato de incorporar. Cadernos de Teatro, Rio de Janeiro, v. 132, p. 12-18, 1993b. Disponível em: http://otablado.com.br/media/cadernos/arquivos/CADERNOS_DE_TEATRO_NUM_I32.pdf. Acesso em: 27 dez. 2019.

. The Shifting point. New York: Harper \& Row, 1987.

. La Conférence des Oiseaux, 1979. Peter Brook site officiel, 1979. Disponível em: http://www. newspeterbrook.com/1979/07//5/la-conference-des-oiseaux/. Acesso em: 19 jan. 2020.

Us: The Royal Shakespeare Production (playscript 9). Londres: Calder Publications Ltd, 1968.

Peter Brook site officiel > News. Disponível em: http://www.newspeterbrook.com. Acesso em: 09 fev. 2020.

CALAdO, Alexandre Pieroni. Presenças. 201I. Tese (Doutorado em Pedagogia do Teatro) - Escola de Comunicações e Artes, Universidade de São Paulo, São Paulo, 20II. Disponível em: https://www.teses.usp.br/ teses/disponiveis/27/27 I55/tde-121220 I I-2334 I4/pt-br.php. Acesso em: 23 jul. 2019. 
CAMPBELL, Joseph. O herói de mil faces. São Paulo: Pensamento, 2007.

CANDE, Daniel. La tempête. Mise en scène de Peter Brook. Théâtre des Bouffes du nord. 1990: photographies. Bibliothèque Nationale De France. Disponível em: https://gallica.bnf.fr/ark:// 2 | 48/btv l b9064676d.r=peter\%20 brook\%20la\%20tempete?rk=2 |459;2. Acesso em: 27 jan. 2020.

CASTRO, Ana Luiza de Magalhães. A conferência dos pássaros: reflexões sobre o ator narrador no teatro de Peter Brook. 2012. Dissertação (Mestrado) - Instituto de Artes, Universidade Estadual de Campinas, Campinas, 2012. Disponível em: http://www.repositorio.unicamp.br/handle/REPOSIP/284555. Acesso em: 23 jul. 2019.

CAVALIERE, Arlete; VÁSSINA, Elena; SILVA, Noé (org.). Tipologia do simbolismo nas culturas russa e ocidental. São Paulo: Associação Editorail Humanitas, 2005.

CAVALIERE, Arlete; VÁSSINA, Elena (org.). Teatro russo: literatura e espetáculo. São Paulo: Atelier Editorial, 2011.

CRAIG, Edward Gordon. Rumo a um novo teatro e cena. São Paulo: Perspectiva, 2017.

CROYDEN, Margaret. Conversations with Peter Brook: 1970-2000. London: Faber and Faber, 2003.

CHING, Francis D. K. Arquitetura, forma, espaço e ordem. São Paulo: Martins Fontes, 2005.

DE SOUZA E SILVA, Marta Isaacsson. Le Projet Anderson, Lepage e a performance da imagem técnica. Revista Poiésis, Rio de Janeiro, vol. II, n. 16, p. 63-73, dezembro 2010. Disponível em: http://periodicos.uff.br/poiesis/ article/view/26980. Acesso em: 20 dez. 2019.

DEL NERO, Cyro. Cenografia: uma breve visita. São Paulo: Editora Claridade, 2008.

Máquina para os deuses: anotações de um cenógrafo e o discurso da cenografia. São Paulo: Senac São Paulo: SESC SP, 2009.

DORNEY, Kate. Peter Brook - life and work in pictures 1930s-1970s. V\&A Blog, 21 mar. 20I5. Disponível em: https://www.vam.ac.uk/blog/museum-life/peter-brook-a-life-and-work-in-pictures. Acesso em: 09 out. 2019.

DRAY, Daniel. \#Théâtre: Brook, Bergman, Bêtes de scènes! Le Francofil', França, 19 mar. 2018. Disponível em: https://www.lefrancofil.com/I 7493/suede/theatre-brook-bergman-betes-de-scenes/. Acesso em: 04 jan. 2020. 
EICHENBERG, Fernando. A grande chegada: A nova peça de Peter Brook, La Tragédie de Hamlet, marca a estreia do grande encenador nos palcos brasileiros. Revista Bravo!, São Paulo, ano 5, número 57, p. 70-80, jun. 2002.

O poeta do Espaço Vazio. Revista Bravo!, São Paulo, ano 4, número 37, p. I I4-I I8, out. 2000.

ELIAS, Larissa. Está a venda o jardim das cerejeiras: Peter Brook via Anton Tchekhov. Rio de Janeiro: 7Letras, 2015.

ELIADE, Mircea. O sagrado e o profano. São Paulo: Martins Fontes, 1992.

ENCONTROS COM HOMENS NOTÁVEIS. Direção: Peter Brook. Produção: Stuart Lyons. Estocolmo: Karma films, 2004, I DVD.

ESCUDERO, Lorenzo de la Plaza; GOMEZ, Adoración Morales. Dicionário visual de arquitetura. Lisboa: Quimera, 2014.

FARIA, Dilaci S. A Linguagem dos pássaros (Mantiq-at-Tayr) e a mítica do Islã. Sacrilegens - Revista Discente do Programa de Pós-graduação em Ciência da Religião - UFJF, Juiz de Fora, v. 7, n. I, p. I02-I I4, mar. 20 I0. Disponível em: https://periodicos.ufj.br/index.php/sacrilegens/article/view/267I5. Acesso em: 12 jan. 2020.

FLASZEN, Ludwick, POLASTRELLI, Carla. (org.) O Teatro Laboratório de Jerzy Grotowski 1959-1969: textos e materiais de Jerzy Grotowski e Ludwick Flaszen com um escrito de Eugenio Barba. São Paulo: Perspectiva: SESC; Pontedera, IT: Fondazione Pontedera Teatro, 2007.

FOIX, Marita. Peter Brook: teatro sagrado y teatro inmediato. Buenos Aires: Atuel, 2008.

GODARD, Colette. La Cérisaie - Propos recueillis par Colette Godard pour la revue «Comédie Française» Février 198I. Peter Brook, site officiel, mar. I98I. Disponível em: http://www.newspeterbrook.com//98I/03/05/ la-cerisaie-1981/. Acesso em: 10 jan. 2019.

GROTOWSKI, Jerzy. Em busca de um teatro pobre. Rio de Janeiro: Civilização Brasileira, 1992.

GURDJIEFF, George Ivanovich. Encontro com homens notáveis. São Paulo: Pensamento, 2014.

HAMON, Christine; PICON-VALLIN, Beatrice; NEDELCO-PATUREAU, Mirela. La Cerisaie et la vitalité 
tchekhovienne. In: BANU, Georges (ed.). Les voies de la création théatrale - tome 13: Brook : études, textes, propos. Paris: Éditions du Centre National de la Recherche Scientifique, 1985. p. 256-307.

HADOT, Pierre. Exercícios espirituais e filosofia antiga. São Paulo: É Realização, 2014.

HEILPERN, John. Conference of the Birds: The Story of Peter Brook in Africa. Nova lorque: The Bobbs-Merrill Company, 1978.

HELFER, Richard; LONEY, Glenn. Peter Brook: Oxford to Orghast. Londres: Routledge, 1998.

HUBERT, Marie-Claude. As grandes teorias do teatro. São Paulo: WMF Martins Fontes, 2013.

HOROWITZ, Arthur. Prospero's “True Preserves”: Peter Brook, Yukio Ninagawa, and Giorgio Strehler twentieth-century director approach Shakespeare's The Tempest. Cranbury: Associated University Presses, 2004.

HOWARD, Pamela. O que é cenografia? São Paulo: Sesc São Paulo, 2015.

HUNT, Albert; REEVES, Geoffrey. Peter Brook: directors in perspective. Cambridge: University Press, 1995.

KANDINSKY, Wassily. Do espiritual na arte e na pintura em particular. São Paulo: Martins Fontes, 1996.

KUSTOW, Michael. Peter Brook: a Biography. Nova lorque: St. Martin’s Press, 2005.

LA CERISAIE. Direção: Peter Brook. Produção: F.R.3 / C.I.C.T. Paris, 198I, <https://www.youtube.com/ watch? $v=o A W n m A m F 4 e Y>$. Acesso em: 27 set. 2017.

LA TRAGEDIÉ D’HAMLET. Direção: Peter Brook. Produção: Arte France Développement. France: Arte Vídeo, 2004, I DVD.

LAVENDER, Andy. Hamlet in pieces: Shakespeare reworked: Peter Brook, Robert Lepage, Robert Wilson. Nova lorque: The Continuum, 200I.

LECAT, Jean-Guy. One Show, one audience, one single space. [S.I] OISTAT, 2007.

LEFORT, Rafael. Os mestres de Gurdjieff. Rio de Janeiro: Dervish, 1983.

LEMOS, Carlos A. C. O que é Arquitetura? São Paulo: Editora Brasiliense, 1980. 
LIMA, Evelyn Furquim Werneck. Das vanguardas à tradição: arquitetura, teatro e espaço urbano. Rio de Janeiro: 7Letras, 2006.

MAIA, Adriana. O trabalho do ator e a sua origem espiritual. O Percevejo Online - Periódico do Programa de Pós-Graduação em Artes Cênicas PPGAC-UNIRIO, Rio de Janeiro, vol. 2, n. 2, p. I-10, jul./dez. 20I0. Disponível em: http://www.seer.unirio.br/index.php/opercevejoonline/article/view/I445//280. Acesso em: 25 jul. 2019.

MALINA, Jaroslav. The outer and inner spaces of scenography: a conflict between geometry and emotion. In: GRIFFITHS, Malcolm (ed.). Exploring Scenography. Londres: The Society of British Theatre Designers: The Nottingham Trent University, School of Art and Design, 2002. p. 75-8.

MANTOVANI, Anna. Cenografia teatral em São Paulo: entre a tradição e o novo. 1987. Dissertação (Mestrado) - Escola de Comunicações e Artes, Universidade de São Paulo, São Paulo, 1987.

Cenografia. São Paulo: Ed. Ática, 1989.

MCBEAN, Angus. Vivien Leigh as Lavinia,Titus Andronicus. Google Artes and Culture, 1955. Disponível em: https://artsandculture.google.com/asset/vivien-leigh-as-lavinia-titus-andronicus/QAGabDgMZ_sfcw. Acesso em: 03 jan. 2020.

MICHAELIS. Dicionário Brasileiro da Língua Portuguesa. São Paulo: Editora Melhoramentos, 20I5. Disponível em: https://michaelis.uol.com.br/moderno-portugues/. Acesso em: 31 dez. 2019.

MORENO, Newton Fábio Cavalcanti. Teatro de uma saudade. Experiências de memória brasileira em “Assombrações do Recife Velho” \& “Memória da Cana”. 20I I. Tese (Doutorado em Teoria e Prática do Teatro) - Escola de Comunicações e Artes, Universidade de São Paulo, São Paulo, 20II. Disponível em: https:// www.teses.usp.br/teses/disponiveis/27/27156/tde-090920 I I-195/45/pt-br.php. Acesso em: 23 jul. 2019.

MORRIS, Silvia. Looking back and forward: the Birmingham Rep at 100. The Shakespeare blog, 25 mar. 2013. Disponível em: http://theshakespeareblog.com/2013/03/looking-back-and-forward-the-birmingham-rep-at-100/. Acesso em: 03 jan. 2020. 
MOTTA, Gilson. $O$ espaço da tragédia: na cenografia brasileira contemporânea. São Paulo: Perspectiva; Belo Horizonte: Fapemig; Brasília: Cnpq, $201 \mathrm{I}$.

NADAIS, Inês. Peter Brook no quarto escuro com Samuel Beckett. Cultura/Ípsilon - Público PT, 13 mar. 2009. Disponível em: https:/www.publico.pt/2009/03//3/culturaipsilon/noticia/peter-brook-no-quarto-escurocom-samuel-beckett-225672. Acesso em: 16 fev. 2020.

NATACHA DRAMA WORK. Algunas imágenes del teatro de la primera década del siglo $X X$. Todo el trabajo sucio, nov. 2012. Disponível em: http://todoeltrabajosucio.blogspot.com/2012/I l/decada-I9/0.html. Acesso em: 30 dez. 2019.

NICOLESCU, Basarab. Peter Brook et la pensée traditionnelle. In: BANU, Georges (ed.). Les voies de la création théatrale - tome 13: Brook : études, textes, propos. Paris: Éditions du Centre National de la Recherche Scientifique, 1985. p. |43-16I.

O'CONNOR, Garry. The Mahabharata: Peter Brook's Epic in the making. Califórnia: Mercury House, 1990.

OIDA, Yoshi. Artimanhas do ator. São Paulo: Via Lettera, 2012.

Um ator errante. São Paulo: Beca, 1999.

ORTIZ, Sergio Ricardo Lessa. Do espaço vazio ao círculo aberto: rumo à cenografia e indumentária sagradas de Peter Brook. 2013. Dissertação (Mestrado em Teoria e Prática do Teatro) - Escola de Comunicações e Artes, Universidade de São Paulo, São Paulo, 2013. Disponível em: https://www.teses.usp.br/teses/disponiveis/27/27/56/ tde-100220 I4-I I0825/pt-br.php. Acesso em: 12 nov. 2019.

OUSPENSKY, Piotr Demianovitch. Fragmentos de um ensinamento desconhecido: em busca do milagroso. São Paulo: Pensamento, 2016.

PAVIS, Patrice. Dicionário de teatro. São Paulo: Perspectiva, 201 I.

Análise do Espetáculo. São Paulo: Perspectiva, 2003.

PICON-VALLIN, Béatrice. A cena em ensaios. São Paulo: Perspectiva, 2008. 
PINTO, Shogyo Gustavo. Rito, Espiritualidade e Teatro. Caderno de Registro Macu - Teatro Escola Macunaíma, São Paulo, n. 7, p. I2I-I30, jul./dez. 2015. Disponível em: https://www.macunaima.com.br/cadernos/caderno_07/ caderno_07_completo.pdf. Acesso em: 10 jan. 2020

RATTO, Giani. Antitratado de cenografia. São Paulo: SENAC, 1999.

ROBISON, Mark. Scene from the Peter Brook production “The Tragedy of Hamlet” during BAM Spring Series. BAM Archives, 200I. Disponível em: http://levyarchive.bam.org/Detail/objects/88353/overlay/l. Acesso em: 02 fev. 2020.

ROTH, Leland M. Entender a arquitetura: seus elementos, história e significado. São Paulo: Gustavo Gili, 2017.

ROUBINE, Jean-Jacques. A linguagem da encenação teatral, I880-1980. Rio de Janeiro: Jorge Zahar Ed., 1998.

SABINO, Thiago Miguel Lopes Ribeiro Cunha. O teatro para além do teatro: espiritualidade e ritual em encenações de Jerzy Grotowski. 2016. Dissertação (Mestrado) - Instituto de Artes, Universidade Estadual de São Paulo, São Paulo, 20 I6. Disponível em: https://repositorio.unesp.br/handle/I I449//44502. Acesso em: I5 jan. 2020.

SILVA FILHO, Almir Ribeiro da. Edward Gordon Craig e o Über-Marionette: A pedagogia da morte do ator e uma interface com o teatro da Índia. 2014. Tese (Doutorado em Pedagogia do Teatro) - Escola de Comunicações e Artes, Universidade de São Paulo, São Paulo, 2014. Disponível em: https://www.teses.usp.br/ teses/disponiveis/27/27I55/tde-22082016-1348I7/pt-br.php. Acesso em: 31 dez. 2019.

SLOWIAK, James. Jerzy Grotowski. São Paulo: É Realizações, 2013.

SPEETH, Kathelen Riordan. O trabalho de Gurdjieff. São Paulo: Cultrix, 1976.

SPURGEON, Brad. A sublime Rickie Lee Jones at the Bouffes Du Nord - when you could hear her. Brad Spurgeon's Blog, [s.d.]. Disponível em: https://i2.wp.com/bradspurgeon.com/wp-content/uploads/2015//0/bouffes-du-nord. jpg?ssl=I. Acesso em: 04 jan. 2020.

TCHEKHOV, Anton. As três irmãs. O Jardim das Cerejeiras. São Paulo: Veredas, 2003. 
TCHERKÁSSKI, Serguei. Stanislávski e o yoga. São Paulo: É Realizações, 2019.

TODD, Andrew; LECAT, Jean-Guy. The open circle: Peter Brook's Theatre Environments. Nova lorque: Faber and Faber Inc., 2003.

TREATT, Nicholas. The Cherry Orchard by Peter Brook at the Buffet du Nord Theater. I 98 I. Disponível em: https://arzamas.academy/materials/72I. Acesso em: 26 jan. 2020.

TREWIN, John Courtenay. Peter Brook: a biography. Londres: Macdonald \& Co. Ltd., I97I.

VAN DE WATER, Manon. Moscow Theatres for Young People: A Cultural History of Ideological Coercion and Artistic Innovation. Nova lorque: Palgrave, Macmillian, 2006.

VÁSSINA, Elena; LABAKI, Aimar. Stanislávski: vida, obra e sistema. Rio de Janeiro: Funarte, 2016.

VIANA, Fausto Roberto Poço. O Figurino teatral e as renovações do século XX. São Paulo: Estação das Letras e Cores, 2010.

O Figurino das renovações cênicas do século XX: um estudo de sete encenadores. 2004. Tese (Doutorado) - Escola de Comunicações e Artes, Universidade de São Paulo, São Paulo, 2004.

O figurino gerado através do trabalho do autor: uma abordagem prática. 2000. Dissertação (Mestrado) - Escola de Comunicações e Artes, Universidade de São Paulo, São Paulo, 2000.

VIANA, Fausto Roberto Poço; CAMPELLO NETO, Antonio Heráclito C. Introdução histórica sobre cenografia: os primeiros rascunhos. São Paulo: Fausto Viana, 2010.

VICTOR, Pascal. "Hamlet”, según Peter Brook. OFEL de Sylvia Bofill, [s.l.], 2000. Disponível em: https://desingel. be/fr/programme/theatre/peter-brook-cicttheatre-des-bouffes-du-nord-la-tragedie-d-hamlet. Acesso em: 02 fev. 2020.

La tragédie d'Hamlet: photos. deSingel - danse musique théâtre architecture, [s.l.], 2003. Disponível em: https://ofeluprrp.wordpress.com/20 I5/I0/28/hamlet-segun-peter-brook/. Acesso em: 02 fev. 2020.

WARD, David. Transformation Shakespeare's New Theatre. Stratford-upon-Avon: RSC Enterprise, 20 I I. 
WERKEMA, Cristina. Como o Eneagrama pode contribuir para o sucesso. Seis Sigma, São Paulo, s.n., p. 3645, set. 2007. Disponível em: https://www.yumpu.com/pt/document/read//2675500/como-o-eneagrama-podecontribuir-para-o-sucesso-werkema. Acesso em: 10 jan. 2020.

WILSON, Edwin. Principais formas e movimentos teatrais. Cadernos de Teatro, Rio de Janeiro, n. I44, p. I423, jan./ mar., 1996. Disponível em: http://otablado.com.br/media/cadernos/arquivos/CADERNOS_DE_TEATRO_ NUM_144.pdf. Acesso em: 27 dez. 2019.

VÁSSINA, Elena. Nenhum manual ou gramática de arte teatral: alguns apontamentos sobre a formação do sistema de Stanislávski. Revista Folhetim, Rio de Janeiro, n. 30, p. 34-43, 20 I3. Disponível em: http://www.pequenogesto. com.br/wp-content/uploads/2013/10/02_folhetim30_web_tela.pdf. Acesso em: II jan. 2020.

O "novo método" de Stanislaviski segundo seu último texto: “Abordagem à criação do pape, descoberta de si mesmo no papel e o papel em si mesmo". Revista Moringa, - Artes do Espetáculo, João Pessoa, UFPB, vol. 6, n. 2, p. 16-9, jul./dez. 2015. Disponível em: https://periodicos.ufpb.br/ojs2/index.php/moringa/article/ download/27/85/I4490/. Acesso em: 24 jul. 2019. 


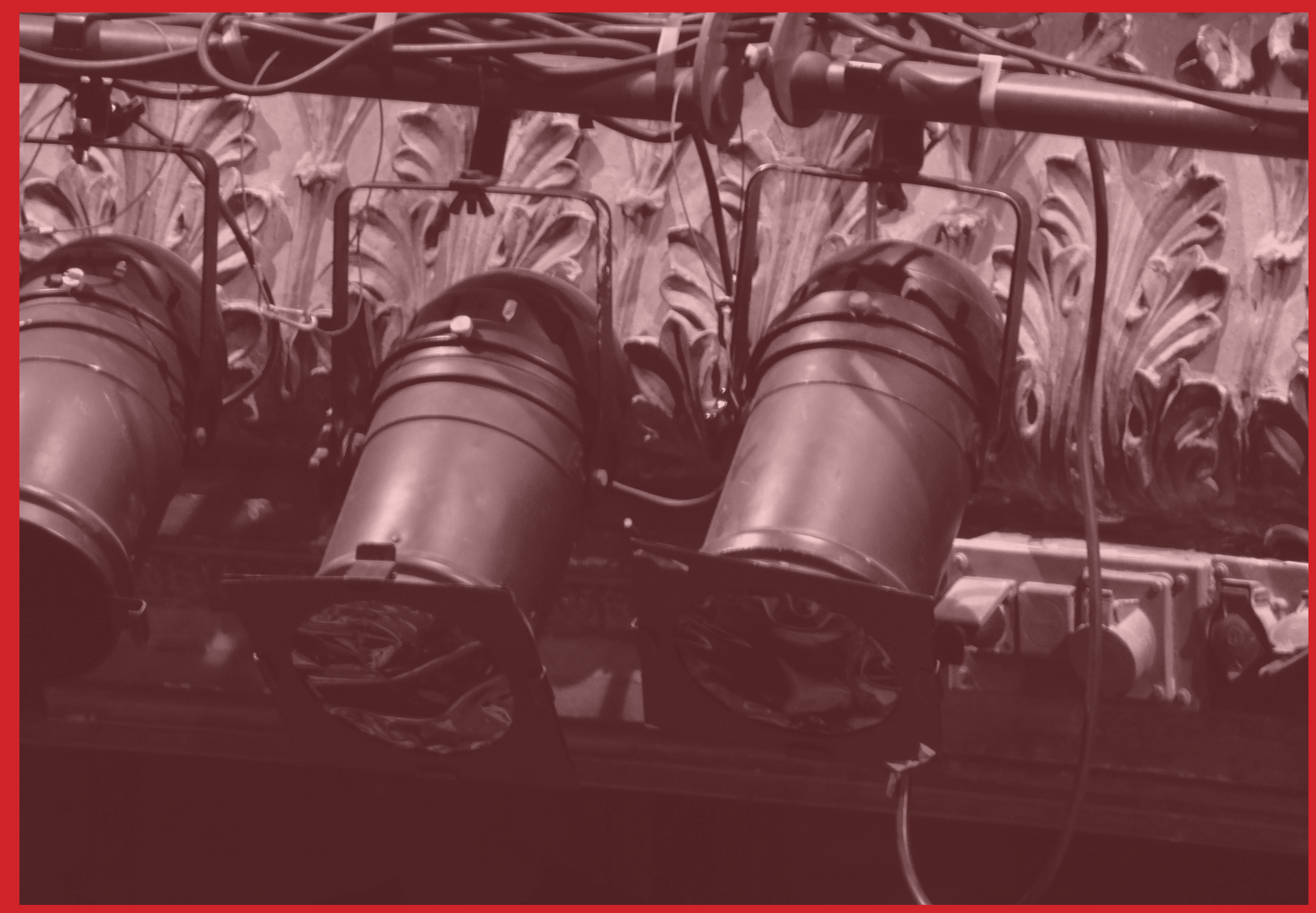



APÊNDICES 



\section{APÊNDICE A - TIPOLOGIAS DE ESPAÇO CÊNICO}

Pretende colocar em evidência um dos conceitos fundamentais para a pesquisa: a espacialidade; de modo a permitir que haja uma maior compreensão da maneira como este elemento evoluiu no trabalho de Peter Brook. Esta escolha, compreender o que significa a espacialidade em Brook, está diretamente relacionada com a forma com que o diretor se aproxima do espaço.

De acordo com o dicionário Michaelis (2015, n.p.), espacialidade é: "natureza ou condição do que é espacial", ou seja, trata-se de um entendimento sobre a organização do espaço. Como esta pesquisa busca aprofundar-se sobre a questão do tratamento cenográfico e espacial no trabalho do diretor supracitado, torna-se, certamente, oportuno refletir sobre a forma como as questões espaciais foram colocadas em cena por ele.

Ao falar sobre questões espaciais, resvala-se tanto na proposição arquitetônica do espaço, quanto nas soluções cenográficas propostas pelo encenador. A respeito da primeira conjectura, o arquiteto e historiador norteamericano Roth (2017, p. 45) define que:

A arquitetura é a arte por meio da qual nos deslocamos, a arte que nos envolve. [...] Frank Lloyd Wright acreditava que o espaço era a essência da arquitetura e descobriu que a 
mesma ideia era expressa por Okakura Kakuzo em $\mathbf{O}$ Livro do Chá. A realidade da arquitetura não está nos elementos sólidos que parecem fazêla: ao contrário, "a realidade de uma sala deve ser encontrada no espaço encerrado pela cobertura e pelas paredes, não no telhado e nas paredes em si”.

Lemos (1980), importante arquiteto modernista paulista, em $O$ que é Arquitetura? afirma que arquitetura está sempre ligada dois conceitos: construção e estética. $E$ sugere que ambas devam estar diretamente relacionadas para que se identifique uma obra arquitetônica. Pertinente à construção do espaço, o autor aponta que se trata da busca por resolver um problema prático: atender ao programa de necessidades, ou seja, às funções que se pretende desenvolver na edificação, como por exemplo em uma residência, o espaço ser definido para as necessidades de dormir, alimentar-se, banhar-se, entre outras.

Contudo, Lemos (1980) ressalta que para que haja arquitetura, é fundamental uma inter-relação entre o atendimento das questões práticas e funcionais do espaço, referentes ao aspecto construtivo, a satisfação das normas técnicas e do programa de necessidades dos seus usuários, sem menosprezar as intenções plásticas pretendidas, provocando emoções e percepções estéticas. No que tange às questões estéticas, indica que esta não é exclusiva da arquitetura, mas da arte em geral.

Roth (2017) complementa ao afirmar que, com o intuito de provocar no usuário e o conduzir a beleza, pintores e escultores provocam os sentidos com a manipulação das relações proporcionais entre as formas, a luz e a cor. Indica que, ao explorar e provocar as mesmas sensações com a alteração espacial, os arquitetos devem modelar alguns tipos de espaço. A saber:

- o espaço físico: aquele que posse der mensurado e expresso em unidades de medida, ou seja, o volume determinado por divisórias espaciais (paredes, piso e teto);

- o espaço perceptual: aquele que pode ser percebido ou visto, inclusive é passível de ampliação, mas não permite sua quantificação, como por exemplo, um edifício com paredes de vidro;

- o espaço conceitual: é relacionado com o espaço perceptual, porém, trata-se daquele que está armazenado em nossa memória, e que permite que os seus usuários possam facilmente compreendê-lo e se locomover por ele;

- o espaço comportamental: é possível de ser utilizado e de se locomover por ele. De certa alguma maneira, define a maneira como seus usuários irão se comportar nele. Podem definir padrões de comportamento por sua própria configuração, independentemente de barreiras 
ou obstáculos (ROTH, 2017).

De acordo com Roth (2017), a apreciação e percepção do ambiente construído é possível, desde que a função e a durabilidade do espaço estejam, também, satisfeitas. Reitera que a percepção e compreensão espaciais são resultantes da maneira como a mente e o olho humano recebem e interpretam os dados da experiência arquitetônica.

Sua apreensão ocorre por meio da percepção visual; do entendimento sobre as relações de proporção; da compreensão de escala, ou seja, da "relação entre ○ tamanho de um edifício, e o de um ser humano médio" (ROTH, 2017, p. 65); do ritmo (alternância entre incidente e intervalo, cheios e vazios); da textura (tanto ótica, quanto a tátil, evidente com a seleção dos materiais utilizados na sua composição); da incidência de luz; das cores utilizadas; dos padrões estéticos de cada época; e, da utilização ou não de ornamentação.

Além da compreensão do espaço por meio de questões referentes à sua arquitetura, é necessário compreender, também, como as relações espaciais interferem diretamente na encenação. De acordo com o professor de estudos teatrais Patrice Pavis (2003) em A análise dos espetáculos, o espaço, a ação teatral e o tempo existem de modo concomitantes, pois um não existe sem a ação dos demais, uma vez que constituem "um mundo concreto e num mundo possível no qual se misturam todos os elementos visuais, sonoros e textuais da cena" (PAVIS, 2003, p. I39).

Segundo Pavis (20II), o tempo se manifesta de maneira visível no espaço, a ação se concretiza em um lugar e em momento específico, e o espaço se situa onde ocorre a ação, que se desenvolve em um certo período de tempo. Deste modo, a experiência espacial, tanto no teatro como fora dele, poderia se encaixar em duas possibilidades, segundo as quais transitam as teorias sobre o espaço:

I. Concebe-se o espaço como um espaço vazio que é preciso preencher como se preenche um container ou um meio ambiente que é preciso controlar, preencher e fazer com que se expresse. Típica dessa concepção seria, por exemplo, a de uma Artaud: "Digo que a cena é um lugar físico e concreto que exige que alguém - preencha, e que o faça falar sua linguagem concreta."

2. Considera-se o espaço como invisível, ilimitado e ligado a seus utilizadores, a partir de suas coordenadas, de seus deslocamentos, de sua trajetória, como uma substância não a ser preenchida, mas a ser entendida. (PAVIS, 20II, p. I4I)

Para Pavis (20I I), o espaço objetivo externo é o espaço visível, que muitas vezes é possível de ser preenchido e descrito, e que pode ser compreendidos em três categorias distintas: espaço teatral, espaço cênico e espaço liminar. 
O espaço teatral, propriamente, é o edifício e sua arquitetura correspondente, inscritos na cidade ou em qualquer paisagem. Pode-se compreender também como - local escolhido para a realização da encenação, que não necessariamente seja um lugar institucionalmente concebido com o uso específico para tal utilização, mas o ponto particular em que se escolheu para realização da experimentação cênica.

Este termo atualmente substitui a palavra teatro, como definição do edifício teatral. Com as transformações da arquitetura teatral ao longo do século $X X$, em particular com a desconstrução do local de representação como sendo somente o palco italiano. Com o processo de renovação cênica, no inicio do século passado, passam a surgem novos espaços de experimentação cênica, como fábricas abandonadas, armazéns em vilas operárias, praças, antigos teatros deteriorados, entre outros, uma vez que o teatro se instala de modo a proporcionar um contato mais próximo com o grupo social que pretende atingir.

O espaço cerca-se por vezes de um mistério e de uma poesia que impregnam totalmente o espetáculo que aí se dá. Assim, o teatro deteriorado Bouffes du Nord, religiosamente conservado em seu estado de origem quando foi encontrado, presta-se maravilhosamente ao estilo bruto e imediato das encenações de Peter Brook. As antigas oficinas da Cartoucherie que abrigam o Théâtre du Soleil e o Aquarium conservam, de seu passado, um ar meio industrial, meio artesanal, e favorecem, para cada encenação, a eclosão de uma cenografia adaptada à sua atmosfera específica (PAVIS, 20I I, p. I38).

A ideia de espaço cênico, bastante significativo para esta pesquisa, por sua vez, é a área em que se realiza efetivamente a representação, geralmente utilizada por atores e técnicos envolvidos na cena. Compreende, também, as áreas técnicas adjacentes como: as coxias e a plateia, além de todo o edifício teatral durante a representação. É o espaço em que o público percebe a cena, ou os fragmentos de cena, com todas as tipologias de cenografia possíveis. É efetivamente compreendido no aqui e agora do espetáculo, devido a evolução da atuação que ocorre durante o evento teatral.

O espaço liminar, no entanto, é a separação, nem sempre evidente, mas existente, entre os espaços do edifício teatral, tais como: divisória entre o palco e a plateia, ou entre o palco e a coxia. Esta divisão é marcada com distintas intensidades pela "ribalta, velas, pelo "círculo de atenção" que o ator traça mentalmente para se isolar do olhar do outro" (PAVIS, 20I I, p. I42). 


\section{TIPOLOGIAS DE ESPAÇO CÊNICO}

Segundo Motta (20l1), em O Espaço da Tragédia, a cena contemporânea é marcada pela multiplicidade e diversidade de experiências. Diferentemente do período Moderno, em que as tendências estéticas eram demonstradas de modo exclusivo, marcadas pela ideia de um ineditismo. $O$ contexto do Pós-Modernismo permite a convivência de diferentes possibilidades estéticas, em que é possível a coexistência de todas as possibilidades, sem que haja a noção de que algumas dessas possibilidades seja mais verdadeira do que as demais.

Para o cenógrafo, um dos signos que explicitam a multiplicidade permitida na cena contemporânea é expressa justamente nas diferentes possibilidades de abordagem do espaço cênico. Sobre a constituição do espaço de representação, atualmente, é possível identificar quatro tendências: permanência da caixa cênica; desconstrução da produção da ilusão; negação do edifício teatral tradicional; e procura por espaços alternativos - que serão esclarecidos a seguir.

\section{Permanência da caixa cênica}

Conforme expõe Mantovanni (1989), o edifício teatral all' italiana, ou teatro à italiana, é o formato mais difundido no mundo ocidental. Pode ser definido por uma clara separação entre o espaço da representação (palco) e
- local do espectador (plateia); e, tradicionalmente, possui um formato de ferradura. Seu exemplar mais emblemático é o Teatro Alla Scala (1778) de Milão, concebido pelo arquiteto Giuseppe Piermarini. Neste teatro, geralmente, o público está dividido entre as áreas da plateia e as frisas - no mesmo nível ao fundo; os balcões e camarotes - divididos em andares; e, as galerias no último andar.

Sobre a área de representação, o palco visto pelo espectador tem medidas mínimas para que as suas dimensões sejam rebatidas tanto nas duas laterais, como no urdimento (parte superior do palco) e no porão (parte inferior que possui elevadores). Estes espaços possuem maquinários que permitem a rápida transformação dos cenários no espaço cênico permitindo que sejam erguidos, baixados ou colocados nas laterais, criando assim a ideia de caixa mágica, um efeito de ilusão para o público.

As origens desse tipo de edificação teatral condizem com o período do Renascimento quando o teatro profano voltou a ser apresentado, primeiramente, para a corte; e, em seguida, para a população. Era pensado de modo a seguir o modelo greco-romano, em que o teatro era o "lugar de abrigo para um povo ideal, com divisões hierárquicas" (MANTOVANNI, 1989, p. 9). Desse modo, os espaços teatrais passaram a ser definidos para cada classe social. 
O Teatro Olímpico (I585) de Vicenza, projetado por Andrea di Pietro, vulgo Palladio, foi um dos primeiros edifícios teatrais com este pensamento. Seu palco é determinado por uma ligeira elevação em relação à orquestra. Possui um cenário fixo constituído por ruas e palácios, em perspectiva, ressaltando a redescoberta mais importante do período em relação ao campo das artes. Contudo, foi no período Barroco em que se criou a estética marcada pelo ilusionismo cênico e pelo desenvolvimento de equipamentos cênicos, responsáveis por ampliar a experiência ficcional do espectador.

Com o desenvolvimento social e o surgimento de novas tecnologias, evidentemente o espaço teatral pensado com a caixa cênica foi aprimorado. Um dos expoentes mais significativos desta transformação foi o maestro, compositor e diretor teatral Richard Wagner, que com a descoberta da iluminação artificial optou por realizar algumas transformações importantes no espaço do teatro à italiana. Uma das transformações mais significativas foi o escurecimento da plateia. Antes de sua intervenção a área destinada ao público permanecia iluminada durante as apresentações, pois seria praticamente impossível apagar todas as velas que eram acesas para a entrada do público.

Desse modo, a iluminação a gás possibilitou um controle da luminosidade possibilitando apagar as luzes da plateia durante as apresentações, evidenciando, assim, as atenções para as ações que ocorriam no palco, aprimorando a concepção wagneriana de espetáculo total. Além da iluminação, outra alteração significativa proposta pelo encenador foi a eliminação dos balcões, camarotes e galerias, retornando a plateias em um formato trapezoidal em que o público se senta diretamente posicionado frontalmente em direção ao palco, de forma ascendente para que não haja interferência na apreciação da cena.

A orquestra foi retirada do palco e seu novo posicionamento, em um vão criado entre o palco e a plateia, abaixo do proscênio, consequentemente incidiu no aumento da distância entre a ação cênica e o espectador. Assim, com todas estas alterações incrementou-se o caráter ilusionista do espetáculo, fato este que estabeleceu uma relação mágica entre o público e a cena, determinado pelo envolvimento com a ação, com a atuação dos atores, com a sonoridade, com a música, com os cenários, trajes de cena e as cores que se tornaram mais evidentes devido à diferença na iluminação do palco.

O fato de iluminar o palco simbolizou uma mudança tanto no comportamento social das pessoas - que deixaram de ir ao teatro como evento social e passaram a assistir ao espetáculo que estava sendo encenado -, como também revelou os defeitos aparentes em cena. 
Vale ressaltar que, nessa época, os cenários, em sua maioria, eram propostos por telões pintados e panos de fundo, o que compunham um contraste significativo com a movimentação dos atores em cena. "Os cenários eram ricos, anedóticos - porque não se baseavam em uma pesquisa histórica - e ilusionistas - porque o público era levado a ver algo que parecia verdadeiro, mas não era” (MANTOVANNI, 1989, p. 22).

Esta poética marcada pelo ilusionismo cênico chegou ao seu apogeu com a estética naturalista que pretendia reproduzir fielmente $o$ ambiente em que se passavam as ações e trajetórias dos personagens. Conforme observa Arnold Aronson (2016), professor de teatro na Columbia University, o desenvolvimento frontal da cena coincidia com o direcionamento da percepção humana, baseado na apreensão direta, de maneira que somente a experiência de configurações cênicas em múltiplos espaços poderia alterar esta estrutura perceptiva.

Segundo as teorias do pesquisador e historiador alemão Lehmann (2007) acerca do teatro pós-dramático, é importante ressaltar que a própria caixa cênica não se limitou somente às convenções do teatro dramático, especialmente o naturalista. Um exemplo das novas possibilidades de exploração dos recursos cênicos do espaço teatral à italiana foi o teatro de imagens de Bob Wilson nos anos de 1980, que destacou a relevância da frontalidade, uma vez que se utilizava dos diversos recursos técnicos dessa tipologia cênica para desenvolver o seu universo de experimentação teatral.

À medida em que deixava mais evidente a moldura da própria caixa cênica, as realizações de Bob Wilson romperam com o ilusionismo tradicional proposto pelo elemento da caixa cênica. Ao explorar uma estética particular, composta por uma forte caracterização dos personagens, com cenários e trajes de cena ficcionais, bastante enfatizados pelos efeitos de iluminação, o diretor americano criou percepções e provocou, sensorialmente, seus espectadores. "Em Wilson, os diversificados recursos teatrais de molduragem fazem que cada detalhe seja objeto da função estética do isolamento e ganhe um valor de exposição próprio" (LEHMANN, 2007, p. 273).

\section{Desconstrução da produção da ilusão na caixa cênica}

Em Olhando para o abismo, Aronson (2016) observa que, no decorrer das primeiras décadas do século $X X$, foram feitas várias tentativas para a criação de novas possibilidades de experimentação espacial cênica que subvertessem propriamente o edifício teatral tradicional exposto anteriormente, alterando desse modo o significado da caixa cênica, explorando novas formas de teatralidade. Todavia, é possível observar que alguns 
encenadores optaram por realizar a desconstrução das convenções teatrais tradicionais baseados na própria caixa cênica, contrariando a saída mais radical do espaço tradicional ou a criação de novos espaços cênicos.

Tanto o teatro épico, idealizado por Bertolt Brecht, como o teatro construtivista de Vsevolod Meyerhold, apresentam essa continuidade do espaço cênico convencional adicionando novos elementos às práticas contemporâneas. Nestas experiências predominam a revelação dos elementos utilizados para criação da ilusão, do mesmo modo em que se tornam elementos expressivos a própria materialidade dos equipamentos e os aparatos cênicos. Todos os elementos de cena a luz, o adereço cênico, os cenários e trajes - ou são valorizados como forma de construção de significado, ou são negados como forma de criação de identidade.

Desta maneira, é possível haver uma integração de elementos, como por exemplo: o objeto, o som e a luz podem ser tornar personagens, da mesma forma que a luz e o figurino podem se tornar cenários. $O$ que reafirma a característica mutável e relativa dos signos teatrais. Sendo assim, esta desconstrução pode ocorrer tanto no interior de um espetáculo teatral, como também, de uma maneira mais intensa, na própria arquitetura, com a transformação do espaço cênico tradicional em uma nova organização espacial. Neste caso, o Théâtre du Bouffes du Nord de Peter Brook, em
Paris, se encaixa perfeitamente, uma vez que o diretor optou por readequar completamente o espaço teatral conservando algumas de suas características originais mais importantes.

\section{Negação do edifício teatral tradicional}

De acordo com Motta (20ll), é possível notar a busca por novos espaços para a representação teatral em encenadores como Georg Fuchs, Adolphe Appia, Edward Craig e Erwin Piscator. Nestes casos, evidenciase a presença de outras possibilidades de organização do espaço de representação que interferem diretamente na relação ator-espectador e acompanham a descoberta de novas formas de teatralidade, sejam elas provenientes tanto das tradições ocidentais como orientais.

Neste contexto, as fontes de reorganização dos espaços cênicos podem ser derivadas de momentos históricos - medieval, grego, elisabetano -, ou mesmo de outras culturas - circo, teatro japonês, entre outros -, como, também, corresponder à imaginação do encenador, cenógrafo ou arquiteto.

Por vezes, esses dois elementos se fundem de tal modo que cenógrafos e arquitetos passam a projetar edifícios teatrais onde a relação frontal não seja predominante, basta lembrarmos o projeto do edifício teatral desenvolvido por Walter Gropius, 
assim como os projetos desenvolvidos por Jacques Polieri, como o "teatro esférico” (MOTTA, 20I I, p. 72).

Motta (20II) esclarece que Veinstein expõe, no texto publicado em 1968, denominado 0 Teatro Experimental, a discussão sobre a criação de diversos projetos idealizados a partir da concepção de novas salas de espetáculo que superassem a relação frontal entre atores e espectadores. Veinstein (apud MOTTA, 20I I) classifica a tendência da concepção arquitetônica teatral em quatro possibilidades, a saber:

- Edifícios tradicionais modificados com novas tecnologias;

- Arquitetura teatral constituída por espaços passiveis de transformação que permitem a estruturação de outras possibilidades de espaços cênicos, conhecidos como: arena, semiarena, elisabetano, entre outros;

- Salas que proporcionem novas formas de organização da relação ator-espectador, ou seja, que permitam distintas composições espaciais;

- Edifícios em que não existe qualquer estrutura arquitetônica fixa, que suprima a distinção cena-sala, com dimensões e formas que sugerem várias possibilidades de disposição cênica. Vale ressaltar que estes projetos, geralmente, fundem arquitetura, tecnologia, urbanismo, performance e artes cênicas.
Os espaços supramencionados são resultados da investigação de novas possibilidades de organização do espaço teatral que permitam a exploração de novas linguagem com maior efeito sensorial, inspirado na pesquisa de Artaud (apud MOTTA, 20II), com a intenção de que a cena teatral se afirmasse como uma poesia espacial.

\section{Espaços alternativos}

Esta tipologia de espaço teatral nega o edifício teatral, propondo a concepção dos espetáculos teatrais em outros espaços, públicos ou privados, tais como: praças, parques, ruas, apartamentos, edifícios, galpões ou fábricas abandonados. A busca por espaços alternativos teve origem nos questionamentos formulados por Antonin Artaud acerca do espaço de representação.

Tornou-se bastante difundida entre as práticas teatrais das décadas de 1960 e 1970, sobretudo em grupos e propostas de trabalho como o Théâtre du Soleil de Ariane Mnouchkine e algumas pesquisas teatrais de Peter Brook, já a frente do Centro Internacional de Pesquisa Teatral. Ainda é uma questão significativa entre os encenadores e grupos teatrais contemporâneos, estabelecendo-se como uma tendência da "estética espacial pós-dramática”, como denomina Lehmann (2007, p. 27I). 
Para Lehmann (2007) é possível compreender os espaços alternativos a partir da divisão em quatro categorias, a saber: espaços temporais; espaços de exceção; teatro específico ao local (site specific); e espaços heterogêneos.

A primeira categoria, denominada espaços temporais, foi inspirada pelo padrão das artes plásticas e, por consequência, prevê, a criação de instalações e ambientes em locais públicos - espaços abertos, edifícios históricos e prédios abandonados -, ou mesmo no palco de um teatro tradicional.

Os espaços temporais do teatro pós-dramático abrem um tempo de várias camadas, que não é apenas o tempo do que é representado ou da representação, mas o tempo dos artistas que fazem o teatro, a sua biografia. Assim, o espaço temporal homogêneo do teatro dramático se estilhaça em aspectos heterogêneos (LEHMANN, 2007, p. 277)

A meta é estabelecer uma experiência temporal em que haja uma fusão nas unidades de tempo e espaço, permitindo, dessa maneira, uma vivência aprofundada da duração temporal, seja pela afirmação do "tempocorpo especializado" - evidente nas propostas de encenação de Pina Bausch -, ou pela criação de espaços de recordação.

Os espaços de exceção estão envolvidos, provavelmente, em um questionamento de ordem social, econômica e política. Desse modo,

É possível que não se deva somente a razões pragmáticas o fato de que grupos teatrais privilegiam igrejas ou edifícios semelhantes a igrejas, bem como galpões de fábrica, que podem lembrar a espacialidade imponente das catedrais e que desvinculados de sua função "mundana" na produção material ganham uma nova aura com o teatro que neles tem lugar (LEHMANN, 2007, p. 280).

O teatro específico ao local ou site specific - termo originário também das artes plásticas -, preconiza que a escolha do espaço de representação indica algumas questões pertinentes ao significado do que será representado, e, portanto, passa a atuar como partido estético da proposta. Sendo assim, tanto o espaço como os espectadores da encenação se tornam coparticipantes do evento cênico.

Assim, o que é posto em cena pelo teatro específico ao local é um segmento da comunidade de atores e espectadores. Todos eles são "convidados" do lugar; todos são estrangeiros ao universo de uma fábrica, de uma central elétrica, de uma oficina de montagem. Atores e espectadores vivenciam a mesma experiência não cotidiana de um espaço descomunal, de uma umidade desconfortável, talvez de uma decadência na qual se identificam vestígios da produtividade e da história. Nessa situação especial volta a se manifestar a concepção do teatro 
como tempo compartilhado, como experiência comum (LEHMANN, 2007, p. 28I-282)

Por fim, a quarta e última categoria trata dos espaços heterogêneos que surgem da necessidade da ativação dos espaços públicos, cuja apropriação aproxima-se mais das práticas de intervenção urbana e, propriamente, da performance. As ações são marcadas pela realização de um percurso nestes espaços públicos, de ocupações e de vivências, e geralmente terminam por colocar em discussão a própria ideia de teatro. 


\section{APÊNDICE B - CENOGRAFIA TEATRAL}

O cenógrafo brasileiro del Nero (2009), em seu livro Máquina para os deuses, afirma que cenografia é a arte de organizar plasticamente o espaço de atuação dos atores, bem como também está envolvida na configuração interna do edifício teatral. A palavra cenografia deriva do termo skenegraphein que, literalmente, significa pintura na fachada da skené - inicialmente era uma tenda utilizada pelos atores para trocar seus trajes de cena e, posteriormente, se tornou uma construção atrás do palco com três portas que permitiam a entrada e saída dos atores durante a cena.

De acordo com o arquiteto romano Vitrúvio ( 1999 apud DEL NERO, 2009), na época Antiga existiam apenas três tipos de cenários: os trágicos, os cômicos e os satíricos. Cada um deles era elaborado diferentemente dos demais, de acordo com as necessidades da encenação. Assim,

O cenário trágico é construído com colunas, pedimentos, estátuas e outros elementos que pertencem ao palácio real. As cenas cômicas retratam casas particulares e longas salas com janelas, como nas casas reais. Cenas satíricas são decoradas com árvores, grutas, colinas e outros elementos rústicos, à maneira de uma paisagem pintada (DEL NERO, 2009, p. I43).
Pavis (20II) expõe que a cenografia recebeu diversas atribuições ao longo do tempo. Foi, para os gregos, a arte de adornar o teatro e a decoração com pinturas que cobriam a área de troca de trajes dos atores da época. Durante o Renascimento, tornou-se a técnica de conferir profundidade aos olhos dos espectadores por meio do desenho e pintura de um telão de fundo do palco, em perspectiva. $O$ cenário, naquele momento um telão de fundo, em geral ilusionista, contextualizava o espaço cênico em um determinado tempo e espaço. Por um tempo significativo se limitou a uma imagem visual e ilustração sugerida pelo texto.

Desde o início do século $X X$, período vinculado ao Movimento Moderno, o cenário não apenas se libertou de sua função mimética como, também, se tornou a ciência e a arte de organizar o palco e o espaço teatral. De modo a ocupar a totalidade do espaço, e configurar uma definição em três dimensões, explorava tanto as volumetrias possíveis quanto os vazios significativos. $\mathrm{E}$ assim, deixou de ser apenas uma arte pictórica da tela pintada.

Passou, então, a seguir novos princípios, tais como: a escolha de uma forma, ou de um material básico; a busca por um ritmo ou mesmo de um elemento estruturador, servindo como interpenetração visual dos materiais humanos e plásticos exibidos durante a atuação. De acordo com Pavis (20II), a mudança de função da 
cenografia, ao longo do tempo, esteve vinculada à evolução da dramaturgia. Neste processo, durante algum tempo, esperava-se que o cenário materializasse as ideias do texto de modo a conferir verossimilhança.

Nos tempos atuais, conceber uma proposta cenográfica não significa mais realizar uma ilustração ideal da realidade, permite-se, no entanto, que atue como dispositivo próprio "para situar o sentido da encenação no intercâmbio entre um espaço e um texto" (PAVIS, 20II, p. 45). Assume, então, o resultado de uma concepção semiológica da encenação, responsável pela composição entre os diferentes materiais cênicos, adquirindo interdependência dos demais sistemas da encenação, em particular da imagem e do texto.

Desenvolver uma proposta de cenário é, portanto, estabelecer uma relação correspondente entre o espaço idealizado pelo texto e aquele apresentado no palco. O cenógrafo, responsável pela proposta dos cenários, precisa levar em conta as características do espaço teatral em que será apresentado o espetáculo, principalmente para identificar as configurações do palco, a relação palco-plateia, além da inserção do público na construção teatral, bem como os acessos para a área de atuação e do edifício teatral.

Em qualquer proposta de cenografia, o ideal é que ela seja adequada à concepção do espetáculo. $\mathrm{O}$ bom resultado está tanto em ser perfeitamente integrado à proposta central da encenação quanto na inventividade e no uso adequado dos elementos e materiais propostos. O cenógrafo deve se utilizar de elementos como cor, luz, formas, volumes, texturas e linhas para alterar o espaço e transmitir a mensagem desejada.

Em alguns casos, quando há uma supervalorização da cenografia em detrimento dos demais componentes da encenação, em que se ressaltam os volumes e as cores do cenário, com o pretexto de ser uma pesquisa formal, pode haver indícios de que o cenógrafo esteja se desviando do trabalho global da encenação para o seu próprio benefício. Fator que efetivamente não resulta em uma proposta adequada para a encenação.

Mesmo com uma ampla variedade de pesquisas contemporâneas sobre cenografia, Pavis (201I, p. 4546) enuncia algumas tendências nas propostas recentes, dentre as quais vale destacar:

- Romper a frontalidade e a caixa italiana, de modo a abrir o palco para a plateia e para os olhares, a aproximar o espectador da ação. Uma vez que o palco italiano é sentido como anacrônico ou hierarquizado e baseado numa percepção distante e ilusionista. [...]

- Abrir o espaço e multiplicar os pontos de vista para relativizar a percepção unitária e fixa repartindo o público em volta e às vezes dentro do acontecimento teatral. 
- Arrumar a cenografia em função das necessidades do ator e para um projeto dramatúrgico específico.

- Reestruturar o cenário levando-o a basearse alternadamente no espaço, no objeto, no figurino: termos que superam a visão congelada de uma superfície a ser revestida.

- Desmaterializar a cenografia: graças ao emprego de materiais leves e facilmente deslocáveis, o palco é usado como acessório de "prolongamento" do ator. A luz e os refletores esculpem na escuridão qualquer lugar ou atmosfera.

Sendo assim, a cenografia deixa de ser um elemento estático tal como era concebido anteriormente, e passa a ser um elemento dinâmico, parte significativa da representação teatral. Em $O$ Espaço da Tragédia, Motta (20II) afirma que a cenografia é uma arte em constante processo de redefinição. Não exclusivamente por necessidade de ajustes na forma de estabelecer a comunicação, que implica diretamente em uma adaptação das questões estéticas, mas também decorrente do aprimoramento e surgimento de novos materiais, de novas tecnologias, como de novas proposições visuais resultante de conjecturas e reflexões das artes plásticas, da arquitetura e do urbanismo.

Conforme explicita o cenógrafo italiano Ratto (1999), a cenografia se manifestará sempre como uma arte integrada, que embora dialogue com outras artes, técnicas e tecnologias, manterá sempre identidade própria. Em Antitratado de Cenografia, Ratto (1999) complementa que a verdadeira cenografia é resultante da presença do ator vestido com seus trajes. Para ele, a movimentação do corpo do ator em cena, nas áreas de sua marcação, cria constantes alterações espaciais que não podem ser desconsideradas na composição cenográfica.

Na realidade, a movimentação de um dos atores faz com que os demais se alterem na sequência. Essa soma de ações dos atores em cena estabelece uma relação com a arquitetura cenográfica que não necessariamente é visível aos olhos dos espectadores, mas que é devidamente perceptível de modo sensorial tanto pela plateia quanto no desenho e na estrutura dramatúrgica do texto. Ratto (1999) também destaca a importância da iluminação na composição cenográfica, indicando que a mesma é responsável por estabelecer as tensões necessárias à leitura do espetáculo.

Reafirmando as ideias expostas pelo cenógrafo italiano, del Nero (2008) adverte que a cenografia deve estabelecer uma relação harmônica entre a tridimensionalidade de sua proposição e o volume do corpo do ator, pois ambos são perceptíveis durante a ação teatral. Para ele, é a arte que deve ser integrada 
às palavras elaboradas pelo dramaturgo, aos conceitos pensados pela direção e à movimentação do ator, que, em última instância, é o responsável pela transmissão da mensagem.

Assim, o cenógrafo não deve ornamentar o palco, mas projetar as intenções pretendidas pela montagem, organizando plasticamente o local de representação. É fundamental que sua solução corresponda à configuração da edificação teatral, podendo inclusive se tornar um partido criativo para a proposta apresentada. Peter Brook sugere que os cenários jamais deveriam ser abolidos, mas deveriam estabelecer uma ligação entre a proposta cenográfica e o espaço teatral. Ao produzir o espaço da ficção, que transita entre a imaginação e a realidade concreta, a cenografia se torna o elemento indispensável da comunicação do teatro, pois cria um sistema visual composto por imagens tridimensionais que interferem diretamente na compreensão da peça.

Com a passagem do Movimento Moderno para as experimentações Pós-modernas, é importante destacar os impactos que a evolução da tecnologia e da ciência imprimiram nas relações sociais e, consequentemente, na encenação. Neste contexto, é perceptível a mudança de sensibilidade das pessoas, uma aceleração exacerbada do tempo, uma valorização das diferenças culturais ideológicas, a implementação do hibridismo e uma movimentação dual entre a ruptura com as identidades em choque com a afirmação das identidades em função do processo de globalização.

Baseado neste contexto, vale ressaltar que as práticas artísticas surgidas a partir das décadas de 1950 e 1960 negam o processo de mercantilização das obras, e passam a valorizar o acaso, os processos, o aqui e agora, a não repetição. Em alguns casos existe uma fusão de linguagens técnicas que tornam difíceis de se estabelecer os limites entre as diferentes propostas artísticas, proporcionando, assim, que o hibridismo sobressaia como uma possível identidade artística pósmoderna.

Algumas das manifestações artísticas que simbolizam exatamente $\bigcirc$ momento supramencionado são as performances, os happenings, as instalações, as intervenções urbanas e as videoinstalações, pois são resultados dessa experiência de fusão artística. Tais experimentações passam por novos modos de compreensão tanto do fazer como da recepção artística, acrescidas por uma compressão espaço-temporal, que se adequam ao surgimento dessa nova sensibilidade.

Destaca-se, também, que, a partir desta conjuntura, as artes cênicas passam por mudanças robustas tanto no que concerne a sua estrutura espacial, quanto na maneira de construção das imagens de cena. De acordo com Motta (20l I), é possível verificar que muitas das características presentes nas distintas manifestações 
teatrais da pós-modernidade têm suas origens no Movimento Moderno.

Essa ruptura ocorreu a partir dos anos de 1950 e alterou, substancialmente, o conceito de teatro, fundamentado na tradição grega clássica, fato este que implicou na apropriação de novas matrizes estilísticas e imagísticas. Contudo, houve um conjunto de explorações filosóficas e reformulações críticas que identificou, nas tradições teatrais do oriente e do ocidente, o conceito de teatralidade que permitiu a permanência de elementos primordiais para o desenvolvimento da montagem teatral.

Sobre teatralidade, Pavis (20II p. 372) a define como “aquilo que, na representação ou no texto dramático, é especificamente teatral (ou cênico)". Segundo Lehmann (2007), este conceito abrange todas as manifestações teatrais, inclusive as ideias de performance mencionadas anteriormente. A ressalva que existe na primeira abordagem é a desvantagem de se compreender essa definição como um traço idealista, remetendo à especificidade do teatro puro.

De acordo com Motta (20I I), nesse movimento, a ideia de representação é superada e reformulada, de modo que se estabelece uma crise desse conceito na raiz do teatro e também da cenografia pós-modernos.
Segundo autores como Teixeira Coelho eSteven Connor, por exemplo, por estarem essencialmente vinculadas à ideia de superação da representação, as teorias estéticas de Artaud constituíram a base para a afirmação de uma estética pós-moderna: elas anunciam a valorização da obracomo-processo, em detrimento do fechamento e acabamento da obra; privilegiam a ideia de apresentação, em oposição à tendência representativa ou mimética que caracterizou o teatro ocidental desde sua origem; afirmam a multiplicidade de eventos visuais e auditivos, isto é, a proliferação e a superposição de signos em contradição. Dissolvem a ideia da obra de arte unificada. Rompem com o princípio da identidade, de modo a relativizar o sentido da obra, - que implica uma valorização da singularidade dos receptores, isto é, o papel decisivo que estes exercem para a construção do sentido da obra. Por fim, as teorias de Artaud propõem a atualização do mito ou do texto clássico (MOTTA, 20I I, p. 68-69). 


\section{Tipos cenográficos}

Se o espaço cênico é determinado pelo tipo de cenografia e pela visualização que o encenador faz em sua leitura para o espaço dramático, o cenógrafo e o encenador têm uma grande margem de liberdade para moldá-lo da forma como acreditam ser a mais adequada. Pavis (20II) estabelece algumas funções dramatúrgicas da cenografia, importantes para auxiliar na compreensão dos tipos e formas de produção cenográfica, a saber:

- llustração e figuração de elementos do universo dramático - trata-se de uma estilização, ou uma escolha pertinente de signos. E varia entre uma abordagem naturalista em que a decoração é uma descrição continua e reprodutiva de elementos pré-existentes dispostos de maneira mimética, até uma simples evocação de alguns traços pertinentes do que precisa ser apresentado em cena.

- Construção e modificações sem restrições do palco, que passa a ser compreendido como local de representação. Nesse caso, não se trata mais de uma representação que tenta reproduzir a realidade, mas apresentam um conjunto de construções, passagens e planos que estabelecem uma base para que os atores construam sua partitura cênica. Desse modo, é possível que os atores construam os lugares e os momentos da ação a partir do seu espaço gestual.
- Subjetivação do palco, que passa a ser compreendido em função de cores, luzes e impressões de realidade e não em função de linhas e massas. Assim, sugere ao público uma atmosfera onírica ou fantasiosa do palco. (PAVIS, 20II)

Vale ressaltar que cada estética cenográfica corresponde a uma concepção espacial que, de alguma maneira, seguem uma das diretrizes expostas anteriormente. Assim, para que seja possível compreender as diferentes tipologias cenográficas apresentadas nessa pesquisa, considerou-se a sua relação direta com a sua proposição espacial, além dos elementos que a compõe.

Parte-se da classificação elaborada pelo cenógrafo e professor Antônio Heráclito Carneiro Campello Neto, revisada e organizada pelo Prof. Fausto Viana, porém, trás alguns complementos e reflexões sobre a classificação exposta anteriormente, como forma de atualização do material exposto. Trata-se de um primeiro levantamento de ideias, a partir da reflexão proposta por Campello Neto. Sendo assim, não se pretende esgotar $\circ$ assunto neste documento, mas apontar uma possível reflexão sobre a classificação da cenografia teatral exposta anteriormente. 
Tabela I. Estilos de cenografia.

\begin{tabular}{|c|c|c|c|c|}
\hline \multirow[t]{4}{*}{$\begin{array}{l}\text { ESTILOS DE } \\
\text { CENOGRAFIA }\end{array}$} & \multirow[t]{3}{*}{ MATERIALIZADO* } & \multirow[t]{2}{*}{$\begin{array}{ll}\text { REALISMO } & \text { ou } \\
\text { ILUSIONISMO }\end{array}$} & & $\begin{array}{l}\text { Realismo (propriamente dito) } \\
\text { Naturalismo } \\
\text { Pictórico* } \\
\text { Tecnológico (técnica de imagem)* }\end{array}$ \\
\hline & & & $\begin{array}{l}\text { Realis } \\
\text { V. } \\
\text { VI. }\end{array}$ & $\begin{array}{l}\text { no Simplificado: } \\
\text { Realismo atmosférico* } \\
\text { Realismo simbólico }\end{array}$ \\
\hline & & $\begin{array}{l}\text { NÃO REALISMO ou } \\
\text { NÃO ILUSIONISMO }\end{array}$ & $\begin{array}{l}\text { VII. } \\
\text { VIII. } \\
\text { IX. } \\
\text { X. } \\
\text { XI. } \\
\text { XII. } \\
\text { XIII. } \\
\text { XIV. } \\
\text { XV. } \\
\text { XVI. } \\
\text { XVII. } \\
\text { XVIII. } \\
\text { XIX. }\end{array}$ & $\begin{array}{l}\text { Trágica* } \\
\text { Épica* } \\
\text { Teatralismo } \\
\text { Formalismo } \\
\text { Construtivismo } \\
\text { Expressionismo } \\
\text { Abstracionismo* } \\
\text { Fantasia* } \\
\text { Simbolismo } \\
\text { Kitsch (Sucata) } \\
\text { Performática* } \\
\text { Pictórico* } \\
\text { Tecnológico (técnica de imagem)* }\end{array}$ \\
\hline & $\begin{array}{l}\text { NÃO } \\
\text { MATERIALIZADO* }\end{array}$ & $\begin{array}{l}\text { REALISMO ou NÃO } \\
\text { REALISMO* }\end{array}$ & $\begin{array}{l}\mathrm{XX} \\
\mathrm{XXI} \\
\mathrm{XXII.} \\
\text { XXIII. }\end{array}$ & $\begin{array}{l}\text { Sonora* } \\
\text { Verbal* } \\
\text { Virtual* } \\
\text { Holográfica* }\end{array}$ \\
\hline
\end{tabular}

Obs.: (*) - são itens que foram ajustados ou acrescentados pelo autor. 
A divisão proposta por Viana e Campello Neto (20l0) parte do pressuposto da materialização do cenário. Contudo, Pavis (20II) evidencia a possibilidade da não construção física dos cenários, ressaltando a cenografia sonora e verbal. Fausto Viana (2010) adverte que Campello Neto não viveu para ver a cenografia virtual nem holográfica. Desse modo, propõe-se a ampliação da classificação anterior com o item materialização, ou não, espacial da cenografia, uma vez que os cenários descritos não necessariamente precisam ser construídos.

A partir da compreensão desta divisão, verificam-se duas possibilidades entre as propostas de cenários: a reprodução da realidade tal qual a conhecemos, que estabelece o efeito de ilusão, descrita anteriormente com o teatro naturalista; e, os cenários que não tentam estabelecer esta ligação com os elementos da vida real. É relevante salientar que foram realizadas algumas alterações na proposta de Viana e Campello Neto (20I0), tais como:

Retirada das classificações:

- Estilismo: este conceito não foi relacionado por Viana e Campello Neto e também não possui nenhuma outra referência em nenhum teórico das Artes Cênicas.

- Naturalismo como estilo cenográfico não realista, como o naturalismo trata da representação exata e fotográfica da realidade não seria possível realização do naturalismo como elemento não realista.
Acréscimo das seguintes classificações (explicadas a seguir):

- Fantasia;

- Pictórico (que pode ser tanto realista como não realista);

- Tecnológico (que pode ser tanto realista como não realista);

- Abstracionismo;

- Trágica;

- Épica;

- Performática;

- Sonora;

- Verbal;

- Virtual;

- Holográfica.

- Ajuste do termo:

- Realismo impressionista para Realismo atmosférico, uma vez que o primeiro termo não é apontado nas definições expostas pelo professor. Além disso, o termo impressionismo segundo Wilson (1996), indica que se trata de um estilo de pintura que teve repercussão no final do século XIX e enfatiza a impressão que os objetos e cenas imprimiam nos pintores. Em relação ao teatro o termo é aplicado às peças de Tchekhov, que se referem às impressões causadas;

- Sucata - Kistch para Kitsch (Sucata), que trata de corrigir a grafia do termo de origem alemã que geralmente é utilizado para designar a categoria de objetos comuns, que copiam referências da cultura erudita, mas 
sem atingir a qualidade do modelo original, que provavelmente na época de um dos autores - Campello Neto - era marcada pelo reaproveitamento de materiais descartados colocados em cena.

Dessa maneira, chegou-se a 22 formas distintas de expressão da cenografia teatral. Dentre as indicações apontadas por Viana e Campello Neto é possível compreender as indicações do seguinte modo:

REALISMO: aspecto real. A cenografia é trabalhada com detalhes isolados, trabalhados de maneira a obter uma composição visualmente equilibrada, dando a impressão de determinado lugar.

NATURALISMO: ilusão fotográfica. Procura reconstruir, nos mínimos detalhes, a realidade no palco.

REALISMO ATMOSFÉRICO: através de objetos, associações, sugestões, tenta-se criar a atmosfera de um certo local.

REALISMO SIMBÓLICO: usam-se vários detalhes associativos para sugerir ou estimular. Como, por exemplo: uma cadeira e mesa em frente a uma cortina. ou um belo galho para sugerir a árvore.

SIMBOLISMO: uso de símbolos em objetos de cena. Colocação de tudo em cicloramas ou rotundas (cortina em semicírculos no fundo e partes de cortinas em faixas retas, colocadas nos lugares dos bastidores). Sugestões elementos, detalhes de construção cenográfica. Mistério. [O espaço simbolista desmaterializa o lugar, estiliza-o como universo subjetivo ou onírico.]

EXPRESSIONISMO: distorção deliberada da realidade. Exagero e alegoria. Iluminação irreal. [O espaço expressionista se modela em locais parabólicos (prisão, rua, hospício, cidade etc.). Atesta a profunda crise que dilacera a consciência ideológica e estética.] ABSTRACIONISMO: sem relação direta com o mundo real, todo o trabalho da composição da cenografia era realizado para obter uma combinação de elementos cênicos, linhas e cores para expressar um clima determinado.

CONSTRUTIVISMO: mecanização da sociedade. Deixa exposto o sistema de construção do cenário: escadas, engrenagens, ferro velho, ou melhor, sucata, metais e tubos. Esta linha teatral é marcada pelo geometrismo.

FORMALISMO: área de ação cênica despojada. Formas - planos diversos. Plataformas - o mínimo de objetos de cena. FANTASIA: concepção fantástica irreal. Ficção científica. Fábula. Conto de fadas. Imaginação. Sempre com o intuito de estimular o observador através do emprego de com vários materiais e texturas trabalhados de maneira mais sensorial. [Criada pela fantasia, ou pela ordem do imaginário que contém elementos 
inexplicáveis ou incompatíveis com as leis da natureza, geralmente compreendida de maneira subjetiva] (VIANA; CAMPELLO NETO, 2010, p. I48).

Sobre as demais classificações acrescidas ou complementadas pelo autor:

PICTÓRICO - de acordo com Viana e Campello Neto (2010) há registros da utilização da técnica de telões pintados para representação da cenografia desde - teatro grego, para representar painéis marinhos ou campestres, sobretudo na comédia clássica e nos dramas satíricos. No Renascimento houve uma retomada dessa técnica cenográfica, contudo utilizouse o recurso da perspectiva, conferindo, assim, uma noção de profundidade em cena. Geralmente, nos cenários que reproduziam as casas de uma cidade, as mesmas eram pintadas em escala real, e diminuíam à medida em que se afastavam do espectador. Assim, os atores não deveriam permanecer próximos ao telão no fundo do palco. Tais telões tinham por princípio criar cenários ilusionistas que compunham a montagem de maneira espetacular, porém, podiam ser utilizados, também, em composições não realistas. Além disso, foram bastante utilizados em óperas e espetáculos de dança, até que passaram a ser questionados devido aos avanços tecnológicos e à descoberta da energia elétrica.

TECNOLÓGICO - refere-se aos cenários adeptos às novas tecnologias, acolhendo novas mídias e procedimentos técnicos como forma de estabelecer a comunicação com a sociedade. Esta interação da cena com recursos tecnológicos ficou convencionada de "técnica de imagem" por de Souza e Silva (2010). Trata-se do registro do real ou de elemento visual não referencial, que é pré-gravado ou realizado ao vivo, reproduzido sobre a cena por meio de projeção em telas, ou com uso de monitores ou outros tipos de suporte. Assim como o pictórico, os cenários tecnológicos podem reproduzir ou não a realidade de modo a promover o efeito de ilusão. Um dos principais encenadores contemporâneos a utilizar esse tipo de técnica é o canadense Robert Lepage, que a emprega a serviço de construir o imaginário da cena, e assim passou a reinventar as relações existentes entre o jogo do ator, o espaço e o tempo, promovendo novos modelos perceptivos de recepção.

TRÁGICA - segundo Pavis (20I I), o espaço da tragédia clássica se destaca pela ausência, uma vez que se configura como um lugar neutro, de passagem, que fornece suporte intelectual e moral para a personagem, porém não caracteriza o ambiente. É um local abstrato e simbólico em que tudo significa e qualquer caracterização é supérflua.

ÉPICA - um dos pressupostos desse tipo de teatro é o efeito de distanciamento por parte do espectador. 
A cenografia geralmente expõe toda a sua estrutura técnica, deixando claro que se trata de teatro, e não da realidade. Evita-se, portanto, proporcionar o envolvimento do ator e do espectador na trama, com o intuito de provocar a reflexão e de despertar uma visão crítica do que se passa, sem levar ao desfecho dramático e natural.

TEATRALISMO - um estilo de produção e de composição que enfatiza a teatralidade per se. Menos um movimento coerente do que uma qualidade encontrada no trabalho de inúmeros artistas revoltados contra $\circ$ realismo. Este gênero admite o artifício de uma "realidade de palco" ao tempo que se utiliza de elementos tomados livremente ao circo e aos musicais e a entretenimento similares (WILSON, 1996).

$\mathrm{KITSCH}$ - caracteriza-se pelo exagero sentimentalista, melodramático ou sensacionalista. Frequentemente faz uso de estereótipos e chavões inautênticos. Coloca-se em questionamento sobre padrão estético deste tipo de seleção. Provavelmente Viana e Campello Neto colocaram a utilização de sucata como um estilo Kitsch, pois muitos tipos de cenário executados na época eram desenvolvidos com esse tipo de material sem qualquer reflexão estética.

PERFORMÁTICA - A performance busca promover uma alteração nas estruturas tradicionais do teatro de modo a romper com os padrões de encenação do teatro ocidental, fazendo com que o público possa estar mais envolvido com o espetáculo e com a transmissão da mensagem. Desmonta a estrutura ilusionista realista configurada pela caixa cênica. Questiona o papel passivo do espectador. Coloca o público dentro do local em que ocorre a ação, de modo a estimular a sua participação ativa na atuação cênica. Assim, remove definitivamente a separação entre o lugar da realidade e do público, e o espaço ficcional em que os atores desenvolvem a encenação. $O$ espaço da encenação e a arquitetura cênica começam a utilizar espaços não-convencionais e alternativos, e compreender os novos espaços cênicos pois não se enquadravam mais nos antigos modelos. $O$ espaço torna-se parte significativa da encenação. $A$ cenografia performativa por sua vez, trabalha bastante semelhante ao conceito de instalação, porém é parte integrante da encenação. Geralmente é composta por um conjunto efêmero de materiais cênicos sonoros e visuais que estabelecem sensações, informações e situações apresentadas ao público. Se concretiza no momento em que se relaciona com os outros elementos disponíveis para utilização do performer.

SONORA - sugerido através de sons durante a realização da peça. Utiliza-se da técnica radiofônica para a sua composição e pode substituir atualmente o cenário realista e naturalista.

VERBAL - demostrado por meio dos comentários dos 
personagens, ao invés de composto fisicamente. De acordo com Pavis (20II), a técnica do cenário verbal só é possível em virtude de uma convenção aceita pelo espectador: que imagina o espaço cênico descrito, e o transforma imediatamente, assim que há uma nova descrição do espaço cênico.

VIRTUAL - composto pela inclusão de objetos virtuais na cena. Com um ensaio prévio, pode criar a ilusão de que o ator está interagindo com estes elementos. Dependendo da técnica utilizada pode interagir com os objetos projetar sombras como se fosse um objeto real. Essa simulação da realidade é possível com a implementação de sensores instalados nas lentes e nas câmeras que fazem a projeção dos objetos de cena.

HOLOGRÁFICO - é criado com hologramas que são essencialmente imagens criadas com a luz. Para que seja expresso, utiliza-se um suporte fotossensível, placa de vidro ou uma película emulsionada, em que a informação que a luz contém fica ali gravada, e permanece invisível, até que novamente haja a incidência de uma luz num ângulo apropriado, que revela novamente a imagem registada no holograma. Com as técnicas atuais, a imagem holográfica pode flutuar, quer à frente, quer atrás, do plano do holograma. Vale ressaltar que as imagens holográficas, não podem ser traduzidos por meio de outras linguagens, tais como uma fotografia ou um filme, pois elimina a sua peculiaridade. Que pode ser visto e sentido a partir da presença indireta dos elementos reproduzidos por meio do suporte holográfico.

Há ainda duas outras classificações que são apresentadas por Viana e Campello Neto (2010) que, a princípio, não foram acrescentadas diretamente no quadro de estilos de cenografia pelo autor. São apresentadas aqui de modo que se tenha um levantamento mais completo das tipologias teatrais, a saber:

NEUTRO: Não representacional. Planos indefinidos. Ciclorama infinito. Nudez. Iluminação uniforme. A cor cinza é muito utilizada para criar uma atmosfera impessoal.

ESQUELETOS: estruturas trabalhadas com a intenção de obter efeitos decorativos. Prevalência de linhas geométricas. lluminação que projeta sombras dos desenhos das combinações das estruturas (VIANA; CAMPELLO NETO, 2010, p. 149). 

